
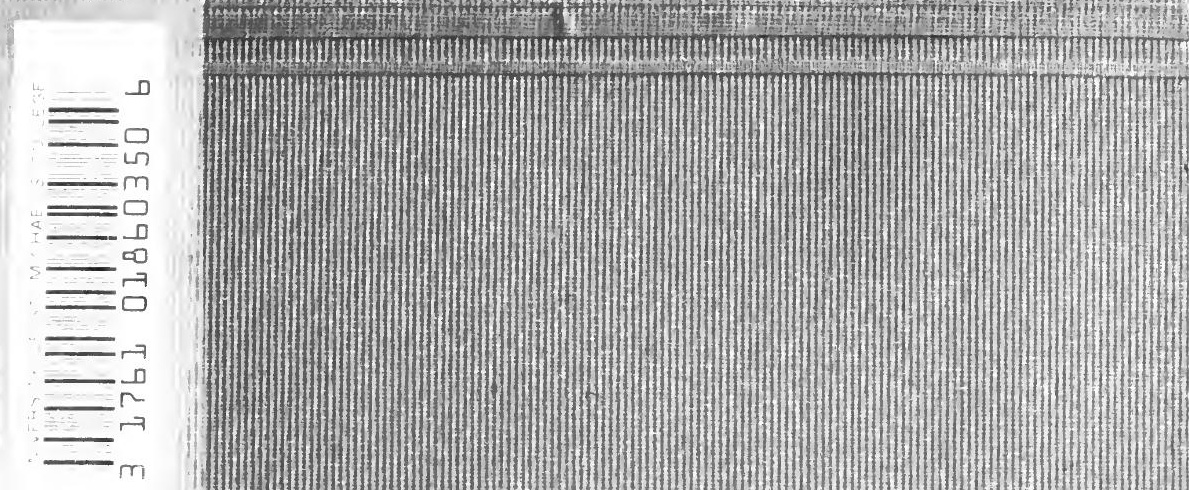


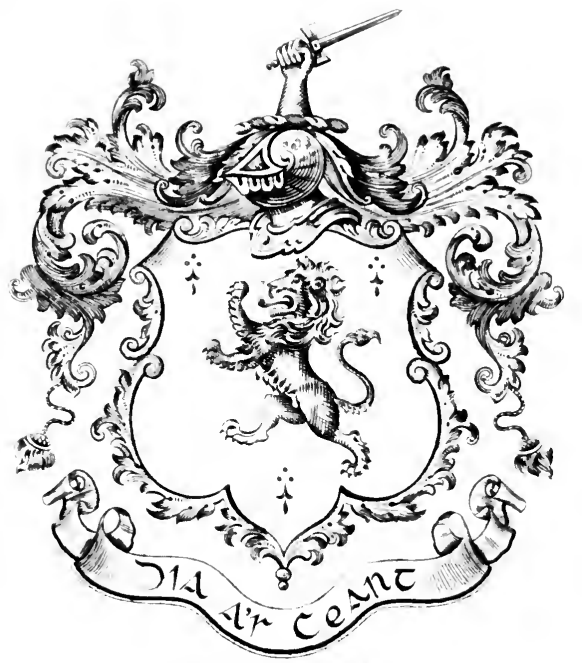

Ex Libisis

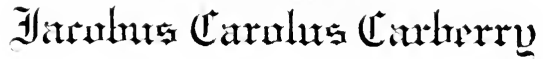




\section{¡CHOLASTICISM OLD AND NEW}

AN INTRODUCTION TO

\section{SCHOLASTIC PIILOSOPHY}

MEIIEVAL AND MODERN

BY

M. DE WULF

DOCTOR OF LAW DOCTOR OS PHLUSUPHY AND LETTERS, PROFESOH AT THE UNIVERSTY OF LOEVAIN

TRANSLATED BY

P. COFFEY, D.Pн.

PRONESSOR OF PHLUSOPHY, MAY YUUTH COLLEGE, IRFLA."

Bublin

M H. GILL \& SON, Ltd.

Tonour

LONGMANS, GREEN \& CO.

39 PATERNOSTER ROW

BOMBAY AND CALCUTTA.

1910 


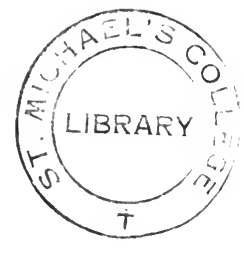

JHN E O 19,1

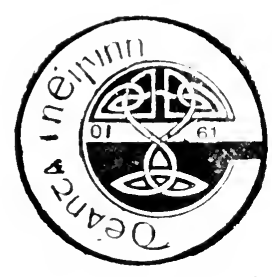

Pinted and Burwit : Irelanh 


\section{PREFATORY NOTE.}

My object in translating Professor De Wulf's Introduction à la Philosophie Néo-scolastique has been fourfold : firstly, to give the advocates and supporters of "modern" systems of philosophy, as opposed to "scholasticism"-whether in its medieval or in its modern form-an opportunity of obtaining better and more authentic information about the latter system than books in English are usually found to contain; secondly, to help students of scholastic philosophy to take in the main principles of scholasticism in one connected view, and to equip them with a more accurate historical and critical appreciation of the system than they are ever likely to derive from an unaided study of stereotyped manuals; thirdly, to give all English readers interested in philosophy of whatsoever kind an insight into the meaning, the spirit and the progress of the movement which has been developing during the last quarter of a century for the revival of scholastic philosophy; fourthly, to prepare the way for translations or adaptations of the Louvain Cours de philosophie, and to draw attention to the value of the work already done and likely to be done in the well-known Belgian centre of the new scholasticism. 
$\mathrm{Vi}$

For information on this latter point I may be permitted to refer the reader to the Appendix at the end of the present volume.

The utility of the book will, it is hoped, be further enhanced by the Index and the Analytical Tiable of Contents.

The reader's kind indulgence is claimed for the many defects of a work accomplished during irregular intervals in the discharge of more pressing duties.

\section{THE TRANSLATOR.}

Mixootu, Augunt, 1907 . 


\section{AUTHOR'S PREFACE.}

Under the title of Introduction to Philosophy there have been published in recent years, and more especially in Germany, ${ }^{1}$ works of a general character, some of which merely deal with questions preparatory to the study of philosophy, while others contain a doctrinal resumé as well. From the nature of things those "Introductions" serve to introduce only one definite system of philosophy-that which has the author's preferences.

It seems likely that a work of this kind, devoted to both medieval and modern scholastic philosophy, will interest not merely those who are already acquainted with scholastic doctrines, but even all who are trying to follow the march of contemporary thought. Whatever may be its extent and duration, the scholastic revival represents at the present time, and will represent in the annals of the Twentieth Century, an intellectual movement that may not be ignored. We still encounter quite a crowd of prejudices regarding modern scholasticism, and many

1 For example: Einleitung in die Philosophie by Paulsen (7 Aufl., Berlin, I90I); by Külpe (2 Aufl., Leipzig, I 898); by Wundt (2 Aufl., Leipzig, 1902); by Jerusalem (2 Aufl., Leipzig, 1902); by Hans Cornelius (Leipzig, 1902); Einleitung in die Philosophie der reinen Erfahrung by J. Petzoldt (Leipzig, I899); Einleitung in die Philosophie der Gegenwart by Riehl (Leipzig, 1903).

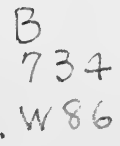


talk about it without understanding it. On the other hand, much that is exact and even suggestive, in its regard, has gained currency at different times and places of late; and it is not altogether easy to collect and compare these later views and to weigh their respective merits.

The object of the present work is to meet and combat false conceptions, to co-ordinate true notions, and so to furnish the reader with some general information on the new scholasticism. The author has adopted quite a summary method. He has merely traced the outlines, raised and stated the problems, but he does not claim to have noticed all the points of view which the subject-matter admits of. Introduction to Scholastic Philosophy being here synonymous with presentation, preparation, the developments of the different questions treated or simply referred to, must be sought in special treatises. He earnestly hopes that the present volume may prove an efficacious invitation to its readers to undertake a personal and deeper study of modern scholastic philosophy.

To form an idea of what the new scholastic philosophy is, one must evidently know what the scholasticism of the Middle Ages was, for the former is only a revival and adaptation of the latter. The two parts of the present work are therefore called for $b y$ the very nature of the subject.

The first part, strictly historical, will " introduce" the reader to this old scholastic monument-to the discredit of which so much has been spoken and written, but which, resembling in so many ways the 
majestic cathedrals of the Middle Ages, decidedly gains by being visited and seen in detail.

The second part will point out the meaning of the attempted restoration and adaptation of this edifice to our own time.

In 1899 we published a brochure entitled: What is Scholastic Philosophy?" which we have been requested on many sides to reprint. Nost of the ideas in that little work will be found here completely recast and developed. We also reproduce, in different places, the theories expressed in an article in the Revue Philosophique of June, 1902, entitled: Notion de la scolastique. At the same time we have taken occasion to reply to various criticisms, ${ }^{2}$ and to give an appreciation of recent works that have put forth general views on the Middle Ages. The reader will accordingly find a fair number of additional ideas on medieval philosophy, supplementing our previous publications.

The two parts of this work correspond like diptychs: the author has tried to compare, point by point, the ideas of the past with those of the present. The new scholasticism is more extensive than the old, being a development and growth of its doctrine: Vetera novis augere. But, on the other band, though the new scholasticism is already constructed in its main outlines it has yet to be perfected in numerous

1 "Qu'est-ce-que la philosophie scolastique?"

2 Directed against our manner of comprehending scholastic philosophy, à propos of our Histoire de la philosophie médiévale (Louvain, I900; 2nd edition, enlarged and revised, I905). 
details. For those two reasons the second part of the work contains a larger number of separate sketches than the first.

Many of the doctrines here dealt with form the subject-matter of the teaching and publications of our colleagues of the Philosophical Institute. We have been happy to make use of those works. Certain developments of Section 15 are borrowed from the conferences of M. de Lantsheere on the sources of Modern Philosophy. Seretions 26, 28. 29, 30 ibre inspired by the recent well known and widely appreciated works of MII. D. Mercier and I). Nys: footnotes will remind the reader in those places.

We may say in conclusion that our exposition of the new scholastic doctrine contains at the same time the programme of instruction which the Louvain Institute of Philusophy has outlined for itself and is endeavouring to carry out.

\section{DE WULF.}

\section{Louvain,}

Christmas, 1903. 


\title{
CONTENTS
}

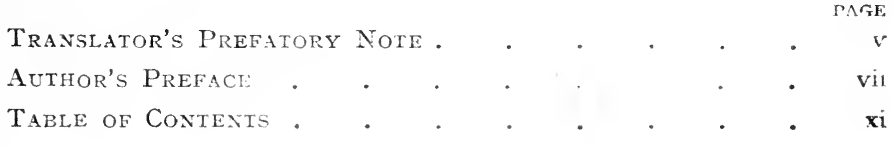

\section{PART I}

MEIIEVAL SCHOLASTIC PHILOSOPHY

\author{
CHAPTER I \\ INTRODLCTORY NOTIONS
}

I. The Common Acceptation of the Term Scholasticism, VAgUe aNd UnfaVotrable. . . .

(I. Vagueness of Tem; 2. Wudern Contempt for Scholasticism since Renaissance; Recent Reaction; 3. Need of Clearness abunt Scholasticism.)

2. The Pont at Issce-A Mistaine to Be Avomed a

(4. Scholasticism is a "Philosophy" : 5. Scholastic Philosophy and Scholastic Theology; 6. Samples of Definitions; 7. Application to Scholasticism-Plan of Chapter.)

3. Scholasticism, the "Dhughter of the Schools" .

(8. The Hord "Scholasticus" ; 9. Hauréau's Defuntion: : Io. Picavet's Definition; iI. Criticism; I2. Comparison with Definitions of "Middle Ages.")

4

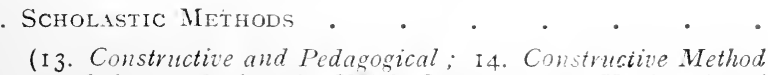
before and after the XIII. Century; I5. Tiniformity of Pedagogical Wethods; I6. Uniformity of Programme: 17. Characteristics of Teaching; the Commentary: I8. Systematic Exposition; 19. The Triadic Scheme. of Treatment; 20. The Syllogism; 21. History of Philosophy; 22. Mixtuve of Philosophy and Theology.)

5. Definitio: of Scholasticisai by its Methods

(23. By its Language; 24. By the Syllugism; 25. Scholasticism as mere Systematization.) 
0. SCHOT, 1SI' I'HHL

20. Con insion of Siholasic with hiedional Phimsuphy: 27. ()ilgin of Compusion; 28. Iis Dhsadaantages; 20. Schol"ticism is "One System" or " Group of Systoms" in lldiceal Philosophy; 30. It is the Sistem propounded by the leading Hestern Whilosophers of the Widdle tecs: 3I. Their Agreoment Compatubie aith Individatal ()iginality: 32. Jociations from Scholasticism; 33. Scholasticism, the Dominant Sistem during the Middle Iges: 3. Anti-Schlasticism.)

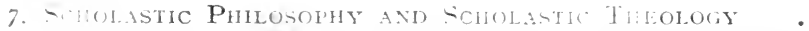

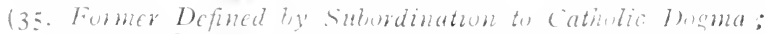
36. " "Sitholasticity" "f a l'hilosophy: 37. Lilationship in Origin and in Tiaching; 3S. Nature and listert if Dutrinal Subordinatum; 3o. ( - rdination of F'ilo-

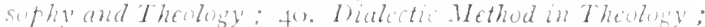
41. Summing up; Cunclusions: 42. Schulasticismand

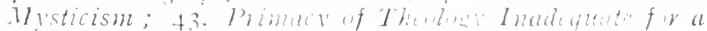

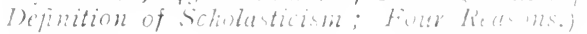

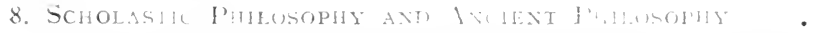

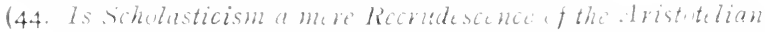
I'hilosophy? 45. Riblions beteeen Schalustic and l'in-

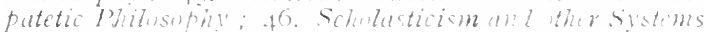

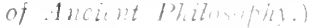

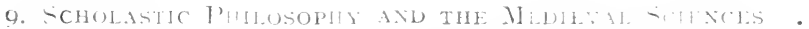

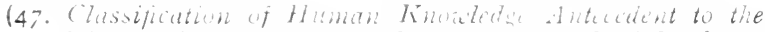
Thirtenth Century; The Liberal Hits and Philusuhpy; +5. Classification Ad pted in the Thintenth Centurve: l'hilosophy and the Sciences; to spembtid l'hilosophy, Phisics, Hathematios, Mctaphisics, Piatical Jhilosophy; 50. ('7 se l wim of Phitosuphy atith the special Scitilces.)

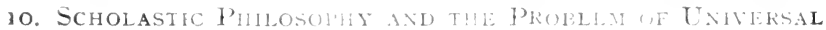
IDEAS

(52. Doctrinal Notions of Tivulasticism: the Latter Canfined to some One Isoluted boctrine; 53. Ficducid to the (i)nivocrsy about Universal Ideas; 54. Place this l)ispute in scholastic Philosophy.)

\section{CH.IPTER H}

I)CORINAL DEFINIIION

11. Condions for a Ductrmal Definition • • •

(55. Strict Technisal Meaning of the Terms! sicince, Philosophical system; 50. Definition "f "System" and of "Sistems" ; 57. Impossible to Describe a "System of I) ictines" by any" "One" Doctrine; 58. A system is an Individual thaole; Ideal of a Ductrinal Defination; 59. Afplication to Scholasticism.) 


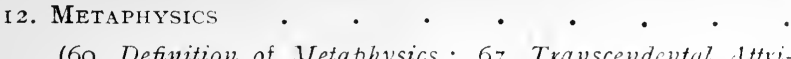

(6o. Definition of Hetaphysics; 67. Transcendental Atributes; Act and Potency ; Movement; 62. Substance and
Accident, Quality, Operative Power; 63. Matter and Form; 64. Functions of Each; 65. The Universals; 66. The Principle of Individuation; 67. Essence and Existence; 68. Causes.)

13. TheOdiCY

(69. Relation of Metaphysics to Theodicy; 7o. Existence of God; 71. His Nature and Attributes; 72 . God and the World; Exemplarism, Creation, Providence.)

I4. General Physics

(73. Object of Physics; 7+. Substantial Change; 75. Rhythmic Evolution and Generation of Forms; 76. Finality of the Universe.)

15. Celestial and Terrestrial Physics $\cdot$ • $\cdot$.

(77. Essential Distinction between Heavenly and Earthly
Bodies: 78. Principles of Astronomical Physics and Mechanics ; Immutability, Unicity and Circular Motion of Heavenly Bodies; 79. Terrestrial Physics: The Four Elements ; The "Mixtum" ; 80. Influence of Heavens on Sublunary Change.)

16. Psychology $\quad$ • . . . . . . . .

(81. Place and Ditision of Psychology; 82. The Soul the Substantial Form of the Composite Human Being: 83. Spirituality and Immortality of the Soul; 84 . Creationism; 85. Faculties of Soul; 86. Knowledgo: 87. "Species Sensibiles" ; Natuve, Seat and Origin of Sensation; 88. Object of Intellectual Concept; Abstraction; 89. Origin of Ideas; 90. Appetite, Sensible and Rational; Liberty'.)

17. Moral Philosophy and Logic . . . . .

(91. Morality; Moral Obligation; 92. Social Ethics: Politics ; 93. Logic ; 94. Place of Logic in the Scholastic System.)

I8. CONCLUSION

(95. General Doctrinal Characteristics.)

\section{CHAPTER III}

\section{THE DECLINE OF SCHOLASTICISM}

19. General Causes of the Decadence of Scholasticisim Towards the Close of the Middle Ages . .

(96. In what Sense are we to speak of a Decay? 97. Faults of Language and Method; Dialectical Abuses; 98. Ignovance of Doctrine; 99 . Scholasticism and the Scientific Renaissance in the Sixteenth Century; 100. Mistake of History'; ror. Conclusion.) 


\title{
PAKT II
}

\section{MOIIERN SCHOLASTIC PHILOSOPHY}

\author{
CHAPTER I \\ SOME EXTRA-IOCTRINAL NOTIONS OF THE \\ NEIV SCHOLASTICISM
}

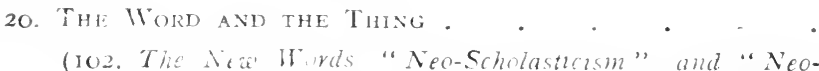

PAGE

I 57

Thumism"; Ioz. Traditional lilement and Innotations an the New Scholastionm; 104. (ancinsinn.)

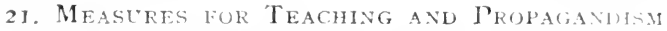

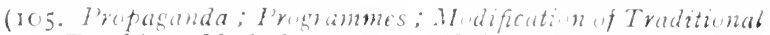

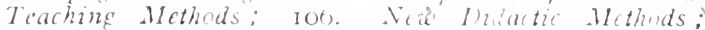

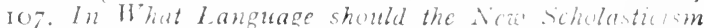
te Taught? State of the (Mustim; History of Thilu. sofhical Latin; IOS. Adiecates of Iatin; Areluments Answed: IOy. Disadiantages of lathm; II ). (ionclision.)

22. THF NHW SCHOLASTCISH ANI THE HISTORY OF PHILOSOPHY 182

(II I. Cinducf the Latter; Causes uf its loeiclopment: II2. The New Schulasticism (dimmt Affurd to Neglect its Cultivation; I 3 . Ilistrical studv is in liecting with spirit of Scholasticism: Its Aduantares to Scholastacism: I 14. Conclusion.)

23. Tize New Scholastic Philosophy ani Relgiols l)ogma I GD

(I I 5. Change of l'edagogic h'elations botiden l'hibsophy and Theology; 116. Detrinal lielations; I'rmiple; Applecation; II7. A l'hilisopher miay te a catholic and Fivect the New Scholasticism; is Conclusimn.)



200

(II). General lifference between the Hedieval and the Modern sciences; I20. Need of a Scientific Philosophy; 121. Need admitted buth by Scholastics and by ddiocates of (ther Contemporary. Systems; I22. Alleged Hostility of Siholastics to Scicnce; Common or Lnscientific Oeserratim not an Adequate Basis for Philosophy; 123. Uramized Teaching of Scientific Philosophy.)

\section{CHAPTER II}

THE DOCTRINES OF THE NEW SCHOLASTICISM

25. Doctainal Innovations

(124. What These Are, in General; 125. Repection of Ialse and Useless Theores; $\mathbf{1} 26$. Testing of Thuse Retained;

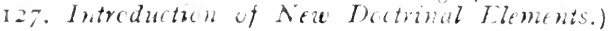


26. Metaphysics

(128. Possibility of Metaphysics; 129. Various Metaphysical Questions of Actual Interest.)

27. THEODICY

(130. Possibility of Theoducy: I3I. Existence of God; I32. Nature of God.)

28. Cosmology

(133. New Facts; I34. Therr Agreement with Scholasticism: I35. Decline of Mechanical Theory of Atomism.)

29. General Psychology . . . . . .

(136. Fertility and Power of the New Scholustic Psychology: 137. Problems Regarding Man's Activities; i 38 . Problems on the Natuve of Man; I39. Lixtension of Sphere. of Psychological Studies.)

\title{
3O. Criteriology
}

(I40. Place of Ciriteriology in Philosophical Curriculam: I 1. Two Fundamental Questions; the "Ideal" Objectivity of Judgments; I42. Their Objective "Reality"; I43. Questions for Special Critcriology.)

3I. ESTHFTICS

(144. Origin of Esthetics as a Special Branch of Philosophy; I45. Its Fundamental Questions; I46. Impression of the Beautiful; I47. Objective Aspect of the Beantiful; I48. Comnection of Two Aspects; I49. Philusuphy of Art; i 50. Conchusion.)

32. Other Branches of a Psychological Character .

(151. Psycho-physiology: I52. Didactics and Pedagogy: I 53. Collcctive or "Folk"-Psychology: Sociological 1'sychology; I 54. Individual Psychology: I55. The New Scholasticism and the Ncw Psychologies.)

33. Ethics and Natural Right

(156. General Ethics; 157. Natural Right or Social Ethics.)

34. LogIC

(158. Fundamental Questions; I 59. Methodology.)

\author{
CHAPTER III
}

THE FUTURE OF THE NEW SCHOLASTICISM

\section{Conclusion}

(160. The New Scholastrcism against Neo-Kantism and Positivism: I6I. Recognition Accorded to the former: 162. Its Future will Depend on its Merit alone.) 


\title{
APPENDIX
}

\author{
(i. Project of a Philosophical Institute, 204; ii. Spirit of \\ Philosophical Studies at Louvain, 268; iii. Influense \\ of the Louvain School of Philosophy, 284; iv. Organi- \\ zation of Courses at the Institute, 289; v. Textbooks \\ and Teaching at the Institute, 298; vi. Philusophical \\ Literature at the Institute, 3II ; vii. Conclusion, 3If).




\section{PART I.}

\section{MEDIEVAL SCHOLASTIC PhILOSOPHY.}




\section{CHAPTER I.}

\section{INTRODUCTORY NOTIONS.}

SECTION 1.-THE COMMON ACCEPTATION OF THE TERM SCHOLASTICISM, VAGUE AND UNFAVOURABLE.

1. The term scholasticism is, in the language and writings of many, a vague designation of the philosophical or theological speculation of the Middle Ages. It sums up for them the mentality of a backward civilisation. "Scholasticism" is the glimmering and uncertain light of "the long night of a thousand years." This unsatisfactory vagueness is aggravated by an unfavourable sense of the word. We are accustomed to depreciate the wisdom of antiquity, and to regard it as the product of a credulous age, with which only the monks and clergy of that time could have been satisfied. And so scholastic has become a synonym for the out-of-date, the naive, the scientifically worthless.

2. This contempt for the scholarship of the Iiddle Ages dates from the Renaissance. And certainly the decadent productions of the fifteenth and sixteenth centuries were calculated to provoke criticisms and reactions ; but then both of these latter were excessive (v. Section 19). Laurentius Valla reprobates that superstitious and senseless race of professors (genus hominum superstitiosum et vecors) who make their pupils swear never to contradict Aristotle.' Ludovicus

1 Dialectica Disputaiiones, Præfatio (Opera, Paris, 1540), p. 643. 
Vivès mercilessly scoffs at the sophismata and dialectical dissoluteness of the University of Paris, whose masters "rave and invent absurdities, and a new sort of language that only they themselves can understand.' '

Those severe strictures grounded the convictions of the succeeding generations: and these latter, improving on the Renaissance, included under one common expression of contempt not only the decadents of the fifteenth, sixteenth and seventeenth centuries, but all the scholastic philosophers in globo. Their science, writes Bacon, degenerated into subtile, vain and unwholesome questions like a decomposing organism (solvitur in subtiles, ranas, insalubres, et, si ita loqui liceat, vermiculatas quastiones ${ }^{2}$ ). The encyclopedists of the eighteenth century expressed their pity for all "who devoted themselves to those miserable scholastic subtilities that consist more in words than in things" ; they made merry over Duns Scotus in whom they found only "vain subtilities and a metaphysic which every man of common sense rejects." and of whom it might be said that " a man who would know fully all he had written would know nothing." 3

And when, in the second half of the eighteenth century. Brucker published his great Historia Critica Philosophire, he had recourse to no other sources, for his estimate of scholasticism, than to those works of its pitiless detractors. Need we be astonished, then, that this critical history,-far too impassioned to deserve its name,-represents the introduction of the western scholars of the twelfth century to the writings

1 "Sominant et confingunt sibi ineptias ac novam quamrlam linguam quam ipsi soli intelligant." In Pscudo-dialecticos (Opera, E(1., 1-82), t. iii., p. 38 .

- De augmentis scientiarum. 1. I, c. 9. Quoted by Brucher, Hit ma Critica Philosuphie, iii., 877 .

${ }^{3}$ Encyclopedie des sciences, des arts ct métzers, published by Diderot and d'Alembert, unler the word "Aristote" (t. i., pp. 603-4). 
of Aristotle as the beginning of a universal stultification ?'

An honest search after truth, the same author concludes, was never the spirit of scholasticism. It contains nothing but a tissue of velitationes philosophica, forming an undigested logomachy." 'Dialectica ista non rationalis philosophia fuit, sed ars rixosa-Metaphysica inani dialecticæ juncta, malum hoc auctum, indeque exortæ logomachiæ innumeræSubtilitas affectata nimia et inutilis-Juncta barbaries sermonis cum barbarie cogitationum': these are a few of the choice rubrics under which Brucker groups his diatribes against a movement of ideas that he condemned without understanding.

Such an attitude, on the part of a man whose name is first on the roll of the great modern historians of philosophy, could not fail to create a widespread distaste for medieval scholasticism. Amongst our contemporaries even, some have rehearsed the same summary condemnations and the same contemptuous prejudices. Taine, for example, considers the epoch of the great doctors of the thirteenth century as an age of "imbecility" worthy only of contempt. "Three centuries at the bottom of that gloomy abyss did not add a single idea to man's intellectual inheritance." 3 Others are of opinion that it is better to "jump clean" across those Middle Ages, regarding them as a disgrace to human thought. The Germans have a name for this indifferentism : Der Sprung über das Mittelalter. So from the closing of the Greek schools by Justinian in 529 to the

1 "Cui (dialecticæ) cum accederent sæculo xi metaphysicæ speculationes, præcisiones mentales, et varia alia mentis otiosa deliria, saculo vero xii Aristotelis metaphysica his elegantiis plena innotuisset, ita hominum horum subtilitas aucta est, ut plane ab humani intellectus natura degeneraret." - Historia Critica Philosophice (Leipzig, I766), t. iii., p. 7 I 2 .

Ibid., pp. 870-871.

${ }^{3}$ History of English Literature, v. i., pp. 223 and 225. 
publication of the Discours de la Methode in 1637, slumbering humanity would have ceased to think, or to bring up before its sovereign reflection the great problems of philosophy! With such naive prejudices it was certainly only natural to take Descartes for a 'saviour' from whom the seventeenth century and modern society once more learned how to philosophize. So, for example, thinks M. Penjon: "If philosophy is, as we have defined it, a free scarch, we may say that from the edict of Justinian (529) to the Renaissance in the fifteenth century there is a sort of interval during which there is, properly spraking. no philosophy. For, during all that period, western humanity was subject, in the region of speculation, to the dogmas that constitute thr Christian traching, and, in the region of morals, to the ecclesiastical discipline founded on those dogmas. We should, therefore, in a history of philosophy, simply skip that interval of eight or nine centuries and pass directly to study the researches that prepared the way for modern philosophy."

Great was the astonishment of the moderns when those pseudo-degenerate Middle Ages began to reveal treasures of philosophic thought to the numerous recent explorers who are still occupied in shovelling away the rubbish of centuries from around that whole epoch. Victor Cousin and his school were the initiators of this modern historical research movement. They made people understand by slow degrees that there was no such thing as a medieval "interlude." and that the sequence of thought was nowhere and no while interrupted. Stöckl. Hauréau, Ehrle, Denifle, Bæumker, Erdmann, Ueberweg-Heinze, Picavet. Willmann, Nandonnet. Baumgartner, Delaaroix-these, to mention only contemporaries-have shown that scholasticism constitutes a movement of ideas as complex and as well worthy of attention

${ }^{1}$ Précis d'histoire de la Philosophie, Paris, IR97, p. If 5. 
as even the finest syntheses of antiquity. The thread of tradition extending from ancient to modern philosophy is now for all time reknotted. Nothing in the world seems less like an intellectual lethargy than the activity of the Middle Ages.

3. And now that the prejudice which has weighed so heavily against medieval philosophy is being gradually dissipated, and what was so long only sneered at is at length being taken seriously, it is high time to get rid of the vagueness that attaches to the word scholasticism. For if it be true that the progress of a science can be judged from the precision of its terminology, a first condition for the progress of Middle Age philosophical history is the exact determination of the meaning we are to attach to the words it is constantly making use of. What then, speaking scientifically, is the meaning of the term "scholasticism"? Many replies have been formulated. A critical examination of them will form the matter of the pages that follow.

Section 2-the point at issue-A mistake to be AVOIDED.

4. People philosophized in the Middle Ages. And it is of philosophical doctrines there is question when we speak of scholastic philosophy. It may seem quite superfluous to insist on this, but it is the only way to make intelligible the discussions we are about to deal with. Now, all philosophy consists in a rational study of all or some of the problems arising from our attempts to explain the universal order of things by their ultimate causes or principles. And hence: either scholastic philosophy is not a philosophy, and then those who talk of it mistake the covering of words for the kernel of reality; or it 
justifies, on some title or other, the general idea just outlined; that is to say, its content represents some attempts, good or bad, superficial or profound, convergent or divergent, to solve the perennial enigmas of the universe.

5. That the latter is the fact, we shall see with all evidence. And that is just why we must not confound, as happens too often, scholastic philosophy with scholastic theology. Theology is not a study of the universal order by the light of human intelligence: it is, at least in its dogmatic portion, a systematization of certain doctrines that a positive revelation has delivered to us. To confound scholastic philosophy with scholastic theology is to confound the examination of natural truths by reason with the study of Christian dogma-as if scholasticism were only, as Brucker expresses it, a discussion of revealed mysteries by the light of the badly understood principles of Aristotelianism." What a number of modern authors fall into the same error and think that " the content of the ideas being fixed by dogma, no liberty remained exerpt in the method of explaining and applying them." 2 If scholasticism be no more than that, we may truly call it no longer a philosophy, but an exegesis of belief, a commentary on the faith, a mere plea pro domo.

This confusion, so easily introduced, between scholastic philosophy and scholastic theology, is due to the wrong interpretation of a group of specific relations that were established by the Viddle Ages

1 "Philosophia hac scholastica qua Aristoteli male intellecto revelationis mysteria subjiciens, de eorum sensu juxta illius prxepta cisputabat." i)p. cit., p. 712.

"Fouillée, Histore de la Philosophue, Paris I\&83, p. I98, etc. The same confusion is evident in a most recent work: "Unter scholastik verstehen wir diejenige Philo-ophie welche die Kirchenlehre als wissenschaftliches schulsy-tem zu begründen und auszubilden sucht." (By scholasticism we understand the philosophy that the Church teaching reeks to establish and develop as a scientific school svstem). Vorländer, Geschichte der Philosophie, Bd. i., Philos. des Altertums und des Mittelalters (Leipzig, Iguz), p. 233. 
between those two branches of speculative study, and which will form the subject of a full investigation further on (Section 7). It perverts the very meaning of an historical study of medieval philosophy, by making that study a mere department of the history of religions.' It is expressly condemned by the scholastics themselves. Their unanimous declarations on the subject cannot leave the least room for doubt. This is the point we have now to establish.

What determines the proper individuality of each of the various sciences, what furnishes us with a test of their diversity, is not, the scholastics tell us, the identity or diversity of the materials which they treat (the material object of the sciences), but the treatment itself of those materials (formal object of the sciences). The distinction between two sciences is altogether due to the distinction between the points of view from which they regard things, of their principles and of their methods of procedure. Just as two architects can build, by different arrangements of the same stones, the one a Roman temple, the other a Gothic cathedral, so can two sciences deal with the same realities provided they approach them from different standpoints. The astronomer, remarks St. Thomas, studies the rotundity of the earth, no less than the physician; but the former draws his proofs from mathematics, the latter from the laws of matter. ${ }^{2}$

So it is with theology and philosophy. Each presents under every respect the characteristics of that independence which is proper to a distinct science. The one is based on the revealed word,

${ }^{1}$ The administrative regulation of the École des Hautcs Études at Paris, which places works bearing on medieval scholasticism in the section of religious sciences, is inspired by this unfortunate confusion.

z"Diversa ratio cognoscibilis diversitatem scientiarum inducit. Eandem enim conclusionem demonstrant astrologus et naturalis; puta quod terra est rotunda. Sed astrologus per medium mathematicum, id est, a materia abstractum ; naturalis antem per medium circa materiam consideratum." Summa Thtologica, ]ma Pars., q. i. a. I. 
the other on the light of reason; the one ss buit up by the way of authority. the other proceeds by scientific proots. Thomas of Aquin. Henry of thent, Bonaventure, codfrey of Fontaines, Duns Scotusin a word. all the scholastics, have given expression to the sime view reatrding the distinction between theological science and philosophical science.

It is of scholastic philosophy there is question here. and of it alone. The author avows his incompetence in the domain of thr history of dogmatic and msstic theologr. He will take acerount of the latter only in so far as may he nexesaler to understand certain relations which are found to have existed in the Middle Ages, as indeed in erery other epoch, between philosophy and the nther great divisions of human knowledge.

6. Definime is a different function from maming. To define, strictly speaking, we must penetrate, as it were, to the depthe of the reality and circumscribe its sphere of being (definime). Naming is simply attaching a name to a thing known in any way whatever. And moreover, names are defined as well as things: all logicians distinguish the nominal and the real definition. The nominal definition is an explanation of the etymological or conventional meaning that attaches to the name. It clears up jdeas and prevents equivocations. But obviously it needs to be followed by a real definition-a definition. of the thing. To define a thing is to tell what the thing is, and what accordingly distinguishes it from every other thing. Real definition is all the mor. perfect the more deeply it penotrates the nature of the thing to be known. If we could grasp in an adequate manner the more fundamental realities of the proper object of a science we should possess that science in its entirety in two or three definitions.

\footnotetext{
1 Aristotle, Anal. put ii.. 3-Cir. Mercer, Leyqu, I'P. 33 . to 333 (Louvain. In: ; fourth edition, sog).
} 
Unfortunately that is an ideal which the human mind, while always aiming at, can never fully reach. This test of the relative perfection of real definitions enables us to appreciate at their true value a double group of them: intrinsic and extrinsic definitions. Everything can be subjected to a twofold process of definition, according as we explore what the thing is in itself, what are its constituent elements and their characteristics - in which case we reach the thing to be defined just as it is, in an absolute and intrinsic way; or, on the contrary, content ourselves with observing the relations of the thing in question with another thing -in which case we reach only its relative and extrinsic aspects. To form for ourselves an idea of the planet on which we dwell we may describe the complexus of elements of which it is composed; or we may consider it in its relations with the sun which gives it light. So far from mutually excluding, the absolute and relative notions complete each other. But it is evident that the former are more important than the latter, and that they alone can lead us to an adequate knowledge of the object to be definedapart from the case of things which consist entirely in mere relations.

7. Let us apply these elementary notions of Logic to the matter in hand. We may define either the name "scholasticism" or the thing which it designates, arriving thus at verbal or real definitions. The latter in turn will be either intrinsic or extrinsic.

Now, since a philosophy is constituted by its doctrinal content we may designate as intrinsic or absolute such notions or definitions of scholasticism as are based on its solutions and doctrines. To look for extrinsic or relative notions of scholastic philosophy is to turn one's back on this doctrinal content and to neglect its peculiar and characteristic significance, for the sake of pointing out the relations, in themselves very numerous, no doubt, and very instructive, 
which exist betwen dements foreign to its doctrine and that doetrine itsolt.

Most of our historians of scholastic philosophy have confind themsotres either to clucidating its nominal definition or to establishing relations extrinsic to its denetrine. Amomest the latter, some lave fixed upon the relations of seholasticism with the language and the sehoeds which have tramsmitted its ideas, or with the metheds that have favoured its teachinge: others have tharacterized it by the epoeh in which

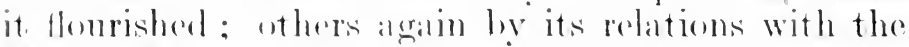

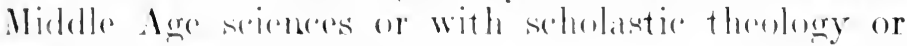
whth ancient phibosophy.

There are these also who have deeiphered some pares of the dextrinal aede of scholastiejom with a view to diseovering inner and differentiating foatures : but instead of reading the houk to the end, they have

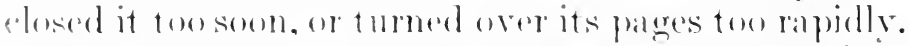

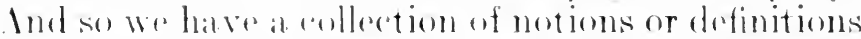
of soholastiosm that present a embous mixture of true and false, of enmmomplater and striking, and many of which are often adopted suecessively by one and the sime anther. We must try to sift them and to determine what elements from amonerst them we ollerht to retain.

The following seheme sums up what has just been said. and will serve as a plan for the subsequent seretions:-

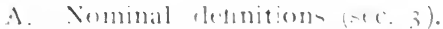

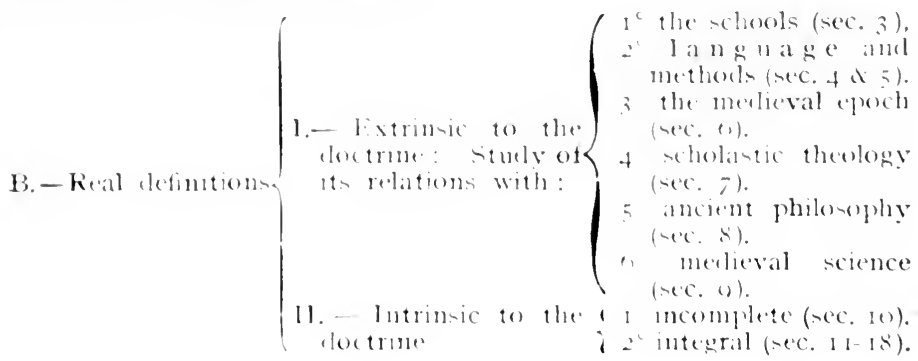




\section{Section 3. - Scholasticism, The 'DAUghter of the SCHOOLS.'}

8. According to etymology $(\sigma \times n) \cdot \dot{\eta}=$ otium $)$, the scholasticus is the man of leisure, the man who is free from the cares of material life or public affairs, and devotes himself - or is thought to devote himself - to the culture of the mind. Greek pedagogy was

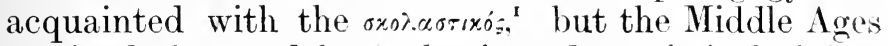
received the word from classic and patristic latinity, which had already given it manifold significations. For Quintilian the scholasticus is a rhetorician or professor of eloquence ${ }^{2}$; St. Augustine calls the pleader at law a scholasticus; St. Jerome applies the name to all distinguished scholars. ${ }^{3}$

From the sixth century the sense of the word scholasticus becomes more and more restricted to the didactic function (scholasticum officium) which was honoured by Charlemagne, and received its own proper privileges and insignia. ${ }^{4}$ The custom becomes common of calling scholasticus or scholar, the titular of any teaching office whether in an abbey school or in an episcopal school. ${ }^{5}$ The science imparted

${ }^{1}$ Ueberweg-Heinze (Geschichte der Philosophe, ii., I898, p. 149) remarks the term in a letter of Theophrastus to Phanias (Diogenes Laertius, v. 50).

2 Quoted by Forcellini, Totuus Latinitatis Lexicon, under the word scholasticus.

${ }^{3}$ St. Augustine, Tr. 7 in Joh. ; "Qui labent causam quxrunt aliquem scholasticum, jurisperitum." -St. Jerome, De viris illusty. cap. 99 (Migne P. L. 23, 738): “ob elegantiam ingenii cognomen scholastici meruit."-Cfr. Pseudo-August., Principia dialectica, Io . "Nam cum scholastici non solum proprie, sed et primitus dicantur ii qui adhuc in schola sunt, omnes tamen, qui in litteris vivunt, nomen hoc usurpant."

${ }_{4}$ Fulbert of Chartres offers Hildegaire the rod and tablets of the schools, scholarum ferulam et tabulas.-Clerval, Les écoles de Chartres au moyen $\hat{a g e}$, du Vo. au XVI". siècle (Paris, I895), p. $3 \mathrm{I}$.

${ }^{5}$ Ducange, Glossarium ad scriptores media et infimce atatis, under the word Scholasticus. "Dignitas ecclesiastica, qua qui donatus est, scholis ecclesiasticis præest." The schola palatince createrl by Charlemagne were teaching institutions. See under the word Schola. 
in those schools was called scholastic science or scholasticism, and had for its object either theology or the liberal arts-and amongst these, chiefly philosophy. Does this notion, borrowed from etymology and history furnish adequate elements for a definition of "scholastic philosophy"? We do not think so.

9. What, for example, should we know about Greek Philosophy, were it defined: "the philosophy taught at the agora, at the squares of the Greek cities, later on in special establishments called Lyceums, Gymnasiums, Academies, from the foundation to the decline of those schools, that is, down to the period when a new spirit, the modern spirit. giving birth to imperial decrees, began to encounter the old philosophy and to wrest from it the office of forming and guiding the human intelligence" ?

Now, it is just in such terms, mutatis mutandis, that 1I. Hauréau expresses himself on the first page of his Histoire de la Philosophie scolastique. "Scholastic philosophy," he says, "is the philosophy professed in the schools of the Middle Ages from the foundation to the decline of those schools, that is, down to the period when the extern philosophy, the new spirit, the modern spirit, liberating itself from the shackles of tradition, began to encounter the old, aind to snatch from it the office of forming and guiding the human intelligence." " And, regarding the decay of scholasticism as quite a final and accomplished fact, the learned historian thinks that the art invented by Gutenberg dealt it the coup de grace. Up to that time, in fact, the rarity of the manuscripts obliged studious people to undertake long journeys to follow the lessons of the public schools. "As soon as the

\footnotetext{
'Hauréau, Historve de la Philusuphie scolastique, v. i. (1'aris, 1872), p. 3t. Similarly in the Dictionnaive des scitnos fhibophiquts, he writes, under the word Scolastiqu" "Scholasticism is the philosophy taught in the whools of the Midrle Ages."
} 
Press had multiplied copies of the ancient texts, and even of more modern glosses, a person might follow up his studies to the limits of the science without frequenting the public schools. . . Heretofore people flocked to Paris from all parts of Europe to follow the courses of the most famous masters; now, however, deserted by the scholars, the public chairs were soon deserted by the professors themselves, and their numbers were seen gradually to diminish. So ended oral or scholastic teaching. Philosophy will be no longer taught didactically, except in convents and colleges, nor will it be accorded the favour of a refuge in those institutions controlled by the Church except on condition of an entire dependence." ‘

Before discussing the definition of M. Hauréau, let us refer, just to show its inexactness, to the corollary he draws from it. If scholasticism be merely the philosophy professed in the schools, it seems strange, à priori, that it should have been smothered by the progress of an art so eminently calculated to increase tenfold the power of oral teaching. For, as a matter of fact, the invention of printing has not synchronized with the decay of the Western schoois. In every country in Europe numerous universities have been seen to spring up posterior to the sixteenth century. And even to-day the growing influence which perfected machinery assures to the Press is far from anything like depopulating the centres of learning. The publication of works will never prevent the youth from assembling around the professor's chair no more than it will ever draw the crowd away from the orator's tribune ; the spoken word is endowed with a persuasive power for which even in the very best of books we may search in vain.

10. Accordingly we are not surprised to find that M. Picavet of the Paris Ecole des Hautes Etudes, 
while attiching himself to M. Hauréau ' draws the contrary conclusion from the principle laid down by his master. Scholasticism remains with him the "daughter of the schools." = It is the "theology or philosophy that is taught, that is sometimes invented or developed. and that sometimes also dies in the schools." 3 But whilst for M. Hauréau the schools, and with them scholasticism, would have ceased to exist at the end of the Middle Ages, for M. Picavet they have survived the invention of printing: and scholasticism outsteps the Middle Ages just like the school teaching of which it is the "daughter." "There are Patonic, Pripatetic, especially Neo. Platonic scholasticisms. There is a Protestant scholasticiom and a Catholic, a Hegelian, a Cousinian, a Schopenhaurian, etc. But scholasticism in the most ordinary sense of the term is the medieval philosophy that we find among the Byzantines, among the Arabs and the Jews, and among the Western C'hristians." 4 The extension thus given by M. Picaret to the notion of scholasticism is more conformable to Lugic than the restriction of $\mathrm{M}$. Hauréau. But is it any happier? Would Hegel, Cousin. Schopenhauer ${ }^{5}$ have been pleased to hear themselves called scholastics. Not only does every teacher of philosophy-Kant as well as Thomas Aquinas. Wundt as well as Boutroux, Paulsen as well as Bergson, M. Picavet himself-become scholastic; but scholasticism reaches beyond the confines of philosophy and theology and embraces every science that can claim a leading exponent and an oral teaching.

'M. Picavet, Nos maitres, I. M. Hauréau (Revue international te l'Ensergnement, Decr. Ifth, Igoo)).

"Revuc Phibsonhique, 1902, p. 185.

"Grande Encyclutedie, under the word "Scolantique."

Ibid.

see Valentiner, Schofenhauer als Scholastake (Leeipzin, rgor) with the sub-title "Ein Kritik der Schopenhauerischen Plulosophie mit Rücksicht auf die gesammte kantische Neuscholastik." What can this author mian by scholastic? 
11. Now all this is simply an abuse of languagea sin against scientific terminology. For everybody without exception, scholasticism simply is a medieval thing; and it is only in the measure in which the notions brought forward by MM. Hauréau and Picavet refer to the Middle Ages that they can be of any interest at all in the present study. The capital vice of the formula that makes scholasticism "the daughter of the schools" is that it is devoid of real meaning. It tells us nothing and it cannot tell us anything about the content of the teaching delivered from the medieval chairs. The oral teaching of the Middle Ages was the vehicle of the most widely opposite philosophical doctrines; not to mention the fact that, all teaching being then oral, scholasticism-" the daughter of the schools"-is no more a philosophy or a theology than it is a medical or juridical discipline. The oral character of the teaching being common to all branches of science, that circumstance is useless when we are looking for a differentiating character of scholasticism. No doubt, it is intelligible that schola meant the teaching $\chi_{\alpha}$ ' $^{\prime} \xi_{0} \times \dot{y}^{\prime}$ (8), and scholasticus the teacher of the two sciences which at that time universally marked the crowning perfection of human knowledge. But that trite notion can hardly serve as the basis for an understanding of the philosophy or theology themselves as taught in the schools of that epoch.

12. Moreover, if we only press matters a little, all these purely verbal and etymological definitions become tautologies. Scholasticism coming from schola, to say that scholasticism is the "philosophy taught in the schools," is it not simply to say that scholasticism is scholasticism?

It is interesting to compare the present definition with the one commonly given of the Middle Ages themselves. "There is no term," writes M. Godfrey Kurth, "on whose definition there is a more perfect 
agreement than on that of the middle ages. The middle ages, we are told on all sides, form an intermediate epoch between antiquity and modern times. That is the definition of all the dictionaries and encyclopedias, of all the manuals and resumés. You must not look for any other from the most learned medievalists. Howerer their points of view may differ in their appreciation of the middle ages. they are unanimous when there is question of the definition, and all reply, with an manimity difficult to find on any other question, that the middle ages are an intermediate epoch."

That is to say, in ot her words, that the middle ages are midalle ages.

11. Kurth points out that such a verbal definition is due to the transposition of a phitological classification inte the domain of history. In studying the development of the Latin language from its begimnings down to their own time the philologists of the sixteenth century distinguished three phases: the phase of classical Latin, extending from the beginnings of Roman Society to Constantine the (ireat: the phase of harbarous Latin, embracing, according to their view, not only the disfigured Latin spoken by the Germanic peoples, but even the Latin of the learned as it was preserved in writing after the creation of the modern languages; and. finally, the phase of the Renaissance or of Latinity as regenerated by Humanism.

To distinguish those three ages of Latin, they were called respectively, "the high or superior age. the middle age and the final or latest age." 2 Modelling their divisions on those of the philologists, historians came habitually to regard as intermediate, from the general point of view of civilization, the centuries

${ }^{1}$ G. Wurth, Quist ce que le moyen age? (Paper rearl at Fribourg at the international scientitic Congress of Catholics, August Igth, I897). Brunsels, rsys, p. 3.

- ()p. cit., PP. It to If. 
that had been made intermediate in point of view of latinity.

It is just such an identification that vitiates the definition of scholasticism we have been considering. In the history of philosophy, no less than in general history, we are unconscious legatees of an arrogant and unjust age. The pedagogues of the sixteenth century judged scholastic philosophy en bloc: the sum total of what used to be taught in the schools of the Middle Ages. And they regarded those teachings as the withered fruits of a barbarous and bygone mentality. Some of those puerilities have outlived the Renaissance.

\section{SeCtion 4.- Scholastic nethods.}

13. Method ( $\mu$ stoosos) is the way followed in order to arrive at an end. When there is question of philosophy, this end is either its construction or its communication. During the Middle Ages the system of philosophy called scholastic had its inventive or constructive methods, and its pedagogic or didactic procedure. We will outline these very briefly.

14. Constructive Methods.-Every science takes its constructive methods from what constitutes its formal object or special point of view, the latter giving to the science its specific character (5). Now, scholastic philosophy was not in possession of its ways and means from its very outset. We observe in the formation of its methods a historical progress parallel to the accumulation of its doctrinal patrimony. The early Middle Age period was smitten with an overweening attachment to the synthetic or deductive method. This latter, starting from very general and very simple principles, deduced from them relations more and more special and complex. 
Scholastics and anti-scholastics alike, dearly loved that descending march of the human mind. "It is my purpose," wrote Bathius, "to build up a science by means of concepts and maxims just as is done in mathematics." " St. Anselm of Canterbury draws from the idea of God not only a proof of the real existence of an Infinite, but even a whole collection of theorems relative to His attributes and to His relations with the world. Two centuries before Ansehm, John scotus Eriugena, the father of antischolasticism. stands forth as the purest type of the deductive reanomer. His metaphysice is a long description of the Divine Odysisey. inspired by the monistic. Neo-Platonic conception of the déchéance of the One through successive generations. And even at the threshold of the thirteenth century, Alanus of Lille trys to apply to philosophy a mathematical method which reminds one of the morê geometrico demonstrations of Descartes and of the theorems of spinoza."

Though we find trates of the analytic method in the eleventh and twelfth centuries-notably with Abelard, and with those who, in the controversy about the universals, insisted on the predominance of the psychological point of view-yet we must come down to the brilliant philosophical achievements of the thirteenth century to witness the complete triumph of the method of observation. It impregnates and fertilizes the works of the great thinkers of the thirteenth century, the treatises of Alexander of Halès, of Bonaventure, still more so of Albert the Great, of Thomas Aquinas ${ }^{3}$ and of Duns Scotus. The new method asserts itself in psychology, where

II) Hibd maibus, I'rol.

a Bampartner, Die l'hil sophie des Hanus de Insuits (in the Beitrage

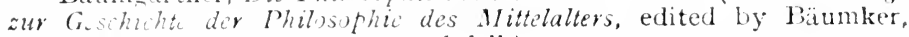
ii., 4. Münster, 1896, pp. 29 and foll.)

[" ("t. an article on "St. Thomas" Physiological I'sychology, by" 1)r. J. Craspuet, in the Dublin [iorica of Arril, 1832-Tr.] 
an exact investigation of the activities of the soul, and principally of the phenomena of sense, intellect and will, is taken as the solid basis of all theories on the nature of man; in cosmology, where the physical and chemical facts brought to light by common observation or by the employment of the scientific processes of the age, give rise to doctrines explanatory of the universe; in ethics, where all is based on the study of the free act; and the same may be said of logic, of theodicy, and even of metaphysics. (Sections 12-17).

Not that the scholastics of the thirteenth century burned what their predecessors had adored. For the ideal of philosophy-of wisdom-is to go back upon the results obtained by observation, and to subject analytic knowledge to the unifying work of some synthesis that sets out from the first cause to come down again to ultimate effects. In all the philosophic matters treated by the thirteenth century, general views abound. The theory of exemplarism studies created essences in their relations to the creating intelligence; cosmic teleology follows out in all their applications the adaptations of beings to the ends they must attain; doctrines such as that on individuation are treated successively from the analytic and from the synthetic points of view. Examples of this kind might be multiplied.

In its definitive and most highly perfected form, such as may be found above all in the thirteenth century, scholasticism employed an analytico-synthetic method-the only one that harmonizes fully with the solutions offered us on the philosophical problems dealt with.

The history of philosophy helps the constructive philosopher in his analyses as well as in his syntheses; and it was for that reason that the scholastics questioned the representatives of the Greek and Patristic philosophies upon the ever abiding problems of human 
thought. But history was for them a perdagogical process also, as we shall see further on when we come to deal ex professo with their conceptions on this matter.

15. Pedagocical Methods.- It is one thing to build up a science, another thing to teach it. The Middle Ages employed didactic methods which bear very little resemblance to the pedagogical procedure of modern times. Those methods were remarkibly unified in the West, though with a uniformity thit did not imply immobility. Scholastic pedagogics are not moulded in stereotyped forms. On the contrary, we witness the rapid spread of innovations, and a continued and universial progress. Amongst the chief causes of internationaliom in methods were the intercommunication between the various intellectual centres and the unity of scientific language.

The wanderings of the principal tearhers of the eleventh and twelfth centuries bear witness to the great frequeney of academic changes. At the great monastic or capitular schools of Bee. Laon, Tours, Auxerre, Chartres, Paris, etc., students, collected togethor from every corner of Europe. may be seen in crowds around masters of world-wide renown. Adelman of Liège and Berenger of Tours go to Chartres to hear the illustrious Fulbert. John of Salisbury is in touch with all the notable philosophers of his time. Manuscripts travelled then no less than books do now. Codices were passed from monastery to monastery, to be copied; some of their fortunate proprietors used to carry them with them through all their long peregrinations.

The multiplicity of those travels backwards and forwards across vast tracts of country-long and costly journeys by sea as well as by land-grew at length to enormous proportions, when, at the close of the twelfth century, Paris saw erected the first university of the Middle Ages. From all sides came 
a rush to Paris, the sapientio fons; and from it streamed forth teachers to spread the light abroad through all Western Europe.

In all the schools philosophy was taught in one and the same-Latin-language. Philosophical works were written in Latin; and so the expression of delicate shades of thought demanded the creation of a special vocabulary and of a specific latinity. Halting as it was in its beginnings, and disfigured in its later days by the barbarisms and dross of the epoch of decadence, yet the scholastic Latin of the great philosophical writers of the thirteenth century, while wanting in the elegance of the language of Cicero, is nevertheless, sober, lucid and pure in form. It is a language of the initiated. If its formulas are complex, they possess in turn the advantage of precision and richness. Thinkers of the stamp of Leibnitz have paid the highest tribute of praise to that terminology, and those who try to translate it into a living language have reason to know the extent of its resources and of its power.

16. To uniformity of language corresponded uniformity of the philosophical programme. Down to the end of the twelfth century, the seven liberal arts, divided into the well-known twofold group of the trivium (grammar, rhetoric, dialectic) and quadrivium (arithmetic, geometry, astronomy, music), formed the basis of intellectual culture in all scientific circles. And just as the quadrivium group opened out gradually into various other sciences, so, too, dialectic developed to such a point as to eclipse the two other branches of the trivium; and to this dialectic universal philosophy became attached by certain ties whose nature we shall investigate more fully later on (Section 9).

1 See, for example, the Thomas-Lexicon of Shütz (2nd ed. Paderborn, Schöningh, I894); the Lexicon Bonaventurum of Joannes of Rubino and Antonius Maria a Vicetio (Venice, typ. Emiliana, 1880). 
From the beginning of the thirteenth century, when the faculty of arts at Paris prescribed the philosophical works to be taught, and the order of teaching them, uniformity of studies became still more marked: the University of Paris was the great philosophical metropolis of the thirteenth and fourteenth centuries, and upon its regulations were modelled those of the other universities.

17. The programme of studies must not be confounded with the method of teaching: it determines the materials to which the method is applied. Here are some details of the pedagrogical system of scholastic philosophy: the commentary, the schematization, the use of the syllogism and of historical arguments, the mixing together of matters philosophical and theological.

Commentury on some text was the chief and natural form of teaching. It was in honour throughout the lliddle Ages: and in order to insure its observance, the faculty of arts in the Paris University determined not only the texts to be commented on, but also the time to be devoted to each commentary. Legere is the consecrated term for such a task. "The lectio is the lesson prir cxcellence: the German word Vorlesungen recalls its historical etymology. Of course the commentary was not necessarily servile. The master might enlarge at will the outlines of the manual, and raise new questions on those suggested by the letter of the text. The works of Aristotle furnished the chief material for such commentary. But the language of the Stagirite is hoary, technical, and often hard to understand-apart from the fact that most of the scholastics. ignorant of Greek, had to be content with translations from the Greek or oftener from the Arabic. For those various reasons Aristotle needed to be explained, and that circumstance of itself contributed largely to keep the commentary long in vogue. 
18. Side by side, however, with the commentary, teachers also had recourse to the systematic treatise, and we find this form followed in quite a number of book-like productions. Still it must be borne in mind that these latter works are not philosophical treatises in the modern sense of the word-devoted ex professo to the study of some branch such as metaphysics or psychology. Works like the Heptateuchon or Thierry of Chartres, a veritable manual of the seven liberal arts, are the exception rather than the rule of that age. On the contrary, most of the productions of the time have each its own proper plan, and each author has his own independent method of treatment. The Monologium of Anselm, the Quastiones naturales of Adelard of Bath, the Sic et Non of Abelard, the Polycraticus of John of Salisbury, the De Potentia of Thomas Aquinas, the De Unitate Forma of Giles of Lessines, the Reportata Parisiensia of Duns Scotus, etc., are no more restricted to a uniform plan than the numerous philosophical works that form our libraries of contemporary philosophy. There were, of course, and especially from the thirteenth century onwards, works modelled on a certain uniform type: the Summa Theologica, systematic treatises of theology and scholastic philosophy with numerous divisions and subdivisions into parts, chapters, articles, numbers, etc.; the Questiones Quodlibetales, collections of solemn conferences given by the University doctors once or twice a year, towards the approach of Easter or of Christmas. But the plan followed, and the order of the questions treated, are not the same in the Summa Theologica of Thomas Aquinas as in that of Albert the Great, or in that of Henry of Ghent. And as for the Quodlibeta, these show the very greatest variety; so that it is quite impossible to try to reduce to any unity the grouping of the questions treated in them. Hence, there is no such 
thing as a regular systematization of scholastic work if we are to understand by that term an assemblage of problems treated according to a stereotyped plan.

19. On the other hand. both professors and writers applied to the study of each individual question a triadic process which became general in the thirteenth century. It consists in a prefatory statement of the pros and cons (ridetur quod non; sed contra) of the thesis: next comes the solution of the question (respondeo dicendum) forming the body (corpus) of the article; and finally, the leplies to the objections (ad primam. ad secumdam. otc.).

This method has a logical connection with the Aristotelian doctrine of the esopice. Aristotle, imbured with the spirit of investigation which he had inherited from the socratic dialectic, insisted on the necessity of collecting all the arguments and roctrines in opposition to a given thesis, and of discussing and refuting them in regular order. It is

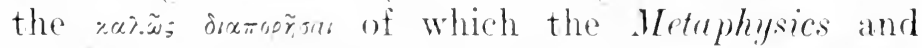
the Nicomachian Ethics make mention.' 'This labour serves as a preparation for personal research ; it defines the points of riew and brings out the force of the difficulties. St. Thomas Aquinas appreciates those wise recommendations of the Metrohysics in the following terms: " Consuetuto Aristotelis fuit, fere in ommibus libris suis, ut inquisitioni veritatis vel determinationi protermitteret dubitationes emergentes" " and again, commenting on the passage of the Nicomachian Ethics just referred to : "Positis his quæ videntur probabilia circa prodicta, prius inducamus dubitationes, et sic ostendemus ommia quar sunt maxime probabilia circa prædicta . . . quia si in aliqua materia dissolvantur difficultates et

2In iii., 1. Wetaph., 1. I. 
derelinquuntur quasi vera illa quæ sunt probabilia, sufficienter est determinatum."

The first application of this didactic method appears in Abelard's Sic et Non and Summa Dialectica. The former treatise submits to the judgment of beginners all the texts of the Fathers relating to the same question and apparently presenting some disagreement with one another. The latter undertakes the same work for dialectic, laying not only sacred, but, this time, profane authors under contribution. Abelard, however, stops short at this contradictory exposition; he leaves the reader in suspense, or rather lets him try to reconcile the conflicting opinions as best he can for himself.

Alexander of Halès perfects this didactic method and gives it its definitive form. While drawing his arguments from the twofold source of authority and of reason, he at the same time uses the abundant materials transmitted by the Greeks and Arabians. Above all, he dissipates the apparent contradictions of the expositions by way of pro and con in the resolutiones that follow. These resolutiones contain a developed and co-ordinated system of philosophy. From those two points of view Alexander is an improvement on Abelard; and the great doctors of the thirteenth century only perpetuate this method. ${ }^{2}$ It permeates all the works of the thirteenth century.

20. To this formal schematization is intimately attached the use of the syllogism and of historical arguments. The syllogism is a didactic procedure of the first order, of which Leibnitz has been able to say: "I am persuaded that if we acted oftener so,

1 In vii., 1. Ethic. ad Nicomachum, 1. I.

- On the origin of this method, see Endres, Ueber den Ursprung $u$. die Entwickelung der Scholastischen Lehrmethode (Philosophisches Yahrbuch, ii., I), and Picavet, Abélarde et Alexandre de Halès, créateurs de la methode scolastique (Biblioth. École des Hautes Études, sciences religieuses, t., vii.). 
if we sent one another syllogisms and prosyllogisms with the replies in form, we could very often, in the most important scientific questions, get at the bottom of things, and dispel a great many imaginations and dreams. By the very nature of the procedure we should cut short repetitions, exaggerations, digressions, incomplete expositions, voluntary or involuntary omissions, mistakes of order, misunderstandings, and all the annoying results that follow from those things." 1

The syllogistic form appears most frequently in the summary exposé of the pros and cons where it has the advantage of resuming and pointing the argument. It is taken up again in the final replies to the objections where it brings to light the defects of the major or minor of those objections. But it also finds a place even in the "body" of an article, and there it enables the author to condense, strengthen and compress his thought as in a vice. Thomas Aquinas and louns seotus make the greatest use of it.

21. One of the best means of finding the pros and cons of a question is by consulting the great thinkers of past ages, and weighing their doctrines, "for there is a presumption that they have a real foundation." " The numerous appeals of the scholastics to the Greek philosophers known at their time, to the Fathers of the Church and to earlier scholastics; the attention they devote to those of their contemporaries who do not share, or who even positively attack, their doctrines, are inspired by no other motive than this. For them the history of philosophy has a double advantage: it enables them to make capital out of other people's ideas. and to meet their errors. It is then a valuable instrument in

- Letter to Whagner, quoted by Mercier, Logique (Louvain, i902), p. I I. [New edition, 1905-Tr.].

"Aristotle, Divin. in s. c., I ; Ethic. i. S. 
the service of true philosophical doctrine; that is its sole raison d'être. Such an absolute subordination of history explains up to a certain point why the scholastics were not sufficiently exact in fixing the historical fact as such. The fault is not peculiar to the scholastics; it is the result of a habit of mind - quite general in the Middle Ages-which did not apply to history a method of strict historical criticism. That is why the historical attainments of the philosophers of this period are not free from error; and we might apply to not a few of them what Henry of Ghent wrote on the subject of St. Augustine : "Philosophia Platonis imbutus, si qua invenit in ea fidei accomodata, in scriptis suis assumpsit; quœ vero invenit fidei adversa, quantum potuit in melius interpretatus est.". This desire to find the truth in the writings of the ancients was a stumbling-block to the right interpretation of their texts.

Then, again, literary authorship was not surrounded by sufficient guarantees in those days, and certain epochs seem to have had no scruple about putting in circulation new treatises under apocryphal titles, or about mutilating and interpolating texts. Alcuin, even at so early a date, speaks of the defloratio or pillage of other people's ideas." Hence the very serious difficulties that beset the work of restoring and assigning to their.respective authors the writings of the Middle Ages. Moreover, they did not all read at first hand the works from which they quoted. A whole crowd of texts, notably of Aristotle and St.

${ }^{1}$ Summa theol. (Edit. I646, Ferrara), art. I. q. I, No. 26.

2 The treatise De Immortalitate Anima of William of Auvergne is an almost literal reproduction of the De Immortalitate Anime of Gundisalvi. V. Baumgartner, Die Erkentnisslehre des Wilhelm von Auvergne (Münster, I 893). In the full light of the thirteenth century we see two religious of the same name (Johannes de Colonia) dispute the literary proprietorship of a work on the Sentences, and the question was fought out before the general Chapter of the Dominicans or FriarsPreachers, in I 269, at a meeting at which Thomas Aquinas was present. Mondonnet, Siger de Brabant et $l^{\prime}$ Averroïsme latin au XIII' siecle (Fribourg, I 899$)$, p. 97. 
Augustine, and of eertain scholastics then in vogue, surh as Borthius and (iilbert de la Porrée, and also of the great Arabian commentators, Avicenna and Averrocis, formed the common patrimony of the schools. These are to be found stereotyped in the writings of all, and were quoted most frequently from memory. But men like Albert the Great and Thomas Aquinas must have had recourse to the sources, for in their writings we find exegetical discussions in abundanee.

Whenever there is question of contemporaries the state of affacirs is different and we generally find the authors well informed. Here, the controversy assumes a character of actuality and its interest decidedly grows. Alanus of Lille is perfectly familiar with the theories of the Cathari and of the Albigenses; Thomas Aquinas lives in permament contact with the Averroist, Siger of Brabant. During an author's lifetime he is rarely referred to save by anonvmous designations such as unes doctor dicit, aliqui dicunt. Albert the (ireat is one of the few philosophers of the thirtenth rentury whe are exceptions to this rule. If those covert allusions were transparent for contemporaries, they are none the less a source of considerable embarrassment for the historian.

2.2. The mixture of philosophical and theological questions and arguments is another peculiarity of the scholastic methods. Pure philosophical questions were discussed side by side with theological questions, somewhat as if we found the same book treating both of physical and of chemical theories. A more typical example could not be mentioned than the group of eighteen questions to be found in the Summa Theologica of Thomas Aquinas, devoted to an investigation of the nature and activities of the human soul. ${ }^{1}$ They constitute a veritable treatise on psychology which, some have ventured

${ }^{2}$ lma $^{\mathrm{mar}}$ Pa, qq. $75-94$. 
to say, "may be taken as complete." I And we find this treatise inserted between a study on the work of the six days of creation, on the one side, and a study on the state of innocence of the first man, on the other. To bring to light, therefore, the philosophical ideas of a medieval writer, it will not suffice to put under contribution his strictly philosophical works; we must also have recourse to his theological productions-as, for example, to the Sentences of Peter Lombard. Nay, more, the quodlibetic disputations often contain, in addition to philosophy and theology, controversies on canon law, ecclesiastical discipline, education, or questions of actual interest at the time.

The origin of this characteristic mixing of philosophy and theology must be traced to the peculiar circumstances that affected the beginnings of scholastic philosophy, and to the disciplinary relations established during the Middle Ages between those two sciences; but this mixture, as such, in no way compromises the distinction between philosophy and theology themselves.

SeCtion 5.-Definition of SCHOLASTICISM BY ITS METHODS.

23. What we have just said will supply us with the necessary data for an examination of the group of definitions of scholastic philosophy drawn from the method of teaching it: definitions which choose as differentiating characteristic some one process or other of a pedagogic nature.

And, firstly, a definition of scholastic philosophy is sought for in the language, or in the use of numerous terms and formulæ which must be penetrated before arriving at the doctrine. "Scholasticism," it is

'Hauréau, Hist. de la philosophie scholast., II'., p. 345 (Paris, I S8o). 
said, " is a philesphy borrowing the peripatetic tongue" ; so that there exists a "contradiction between the matter and the form, since platonic ideas are clothed in peripatetic language." " Or again : Scholasticism requires an initiation, a sojourn at the school, a technical explanation. "To understand it," writes Dr. Hogan, "we have only to remember that, among the causes which contributed most to the diffusion of the Citrtesian Philosophy, was the fact that its author and followers took up and dealt with the highest questions in the hanguage of everyday life. All technical terms were discarded, so that educated persons could, without any special training, follow the developments and discussions to which the new srstem gar birth. Since then philosophy has ceased to be scholastic in the original sense of the word; that is. confined to the schools. In its various shapes it has gone abroad and impressed itself on the literature of the day. It has formed the conceptions and the language of society" . ."

Are those various judgments well founded? Does it not seem, on the contrary. that any language at all that is sufficiently pliable can give expression to any sphere whatever of ideas? A system of philosophy is not constituted by formula of initiation, or by conventional vocabularies; nor is the tie which unites the latter with the former indissoluble. History furnishes us with significant information on this point. Stoicism had the rare merit of creating a new and precise terminology, adapted to an original manner of conceiving the universe. Yet the historians of Stoicism do not define it by its use of a technical language, but by its dynamism, at once monist and materialist. which made it a doctrine sui generis,

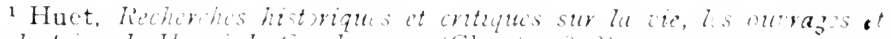
la doctrine de Henvi de liand, p. 93 (Ghent, Is;3).

" "Clerical studien" ly the I. Rev. J. B. Hogan, S.S., 1). I)., P. G. . (Boston, Marlier, 1 bist.
} 
creating an epoch in the evolution of Greek philosophy. The language of the Stoics has survived Stoicism ${ }^{\mathrm{I}}$ it has served other systems, especially Neo-Platonism, and many of its terms have passed over into medieval and even into modern philosophy. Such also was the lot of more than one scholastic formula to be found under the pen of a Descartes, a Leibnitz, and others. ${ }^{2}$ Now, it is clear that in those different cases the language is an accessory to the doctrine. It is not the servant who gives his name to the master; on the contrary, the former is seen to don successively the liveries of those in whose service he is engaged.

As to Dr. Hogan's assertions about the difference between medieval and modern philosophy, they are contestable from more than one point of view. These two philosophies were, of course, propagated in different channels. But this phenomenon is easily explained by the different material and social conditions in which men of science found themselves in the thirteenth and seventeenth centuries. Notably the invention of printing achieved a revolution in the propagation of ideas. And for the purpose of discriminating two philosophical epochs, it is hardly necessary to attach to the presence or absence of a formulary such importance as Dr. Hogan does.

The language of the scholastics is a language of ideas, but ther every well-constructed science has

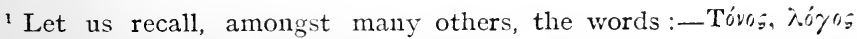

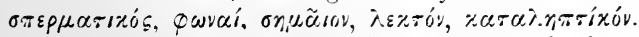

2 The influences of scholastic Latin are to be found in modern French. The latter " underwent, during the Middle Ages, the influence of the low Latin, that new language which theology and scholasticism produced from the classical Latin by modifying it to make it suit new mental requirements, and in which the most eminent thinkers and philosophers of our epoch have written. . . This barbarous offshoot of the classical Latin is at once an original language, serving to give expression to ideas and sentiments heretofore unknown, and also one of the sources of modern French, in all that concerns the expression of abstract, philosophical, religious, scientific, and juridical ideas."-Hatzfeld and Darmesteter, Dictionnaire générale de la langue française, etc. Introd., p. 7 . 
its vocabulary. Besides, it is a mistake to think that modern philosophy has not its technical terminology, though indeed with the drawback of its not being very precise. Descartes has his formulat (esprits animaux, pensée); Leibnitz has his also (monade's, apperception, petites perceptions, etc.); Kant is unintelligible without the aid of a vocabulary ${ }^{1}$ fuller than the scholastie one (a priori jorms. I)ing-an-sich, transcendental Esthetic, categorical imperative, otco). This want of uniformity in the limguage of modern philosophers is creating a eontusion for which there seems to be no hope of remedy. It all events the scholastic formula are intelligible without an master"s explanation from the professorial chair: and many excellent treatises of all sorts enable anvone with the inclination, to familiarize himself with the sound philosophy of the thirteenth century without leaving his desk or his library.

Besides, eren granting that its formulae were accessible only through the commentaries of a prefessor " in a sehonl," that circumstance would leare us still in ignorance of the thought expressed in those formulix.

24. Others define scholasticism by its syllogistic procedure, with the attacks and defences, distinctions and sub-tistinctions, which such procedure implies. "Scholasticism," says Diderot, " is not so much a special philosophy as a certain dry, stifi sort of arguing, to which Iristotelianism, incrusted by hundreds of puepile questions has been reduced." And nearer home, M. Foullée regards scholasticism as a heap of empty formular, "without ideas, drawing consequences ad infmitum without verifying

"Cf. Wegner, Lantluxicun (Berlin, I'eters). See", especially for the "Critique of pure Reason," the Sach-licister in I)r. Vorlander"s editiun (Halle, Hendel), or the important commentary of I). Vaihinger (m four vols., stuttgart and Leipzig, Isis-1 192 ).

2 Works, t. 19, 1). 3()2. 
principles, these remaining above examination." " Or, again, scholasticism means "any mode of thought characterized by excessive refinement and subtlety; the making of formal distinctions without end and without special point." 2

To show how superficial those notions are, we need only consider that the doctrine of Kant may be condensed into syllogisms as well as that of St. Thomas. Would Kant be called a scholastic had he given his transcendental idealism to the world in serried lines of sorites? Is Leibnitz a scholastic because he highly esteemed the resources of the syllogism, and because he himself, in a dispute with a great mathematician, urged the argument as far as the fourteenth polysyllogism? (20) Or, again, is Wolff a scholastic because he adheres to the syllogism and the schema, in those well-known manuals from which all Germany of the eighteenth century learned its rudiments of philosophy ?

25. Sometimes also, scholasticism is defined, not by identifying it with any definite procedure, but by signalizing as its distinctive characteristic, systematization aimed at for its own sake. Whilst the scientific materials accumulated by the Fathers of the Church exist in a state of disorder, scholasticism arranges them in a strictly defined setting. Scholasticism, we read, is Schulwissenschaft, the adaptation of science of whatever sort to the needs of pedagogy. ${ }^{3}$

That fact is indisputable, but it will not afford us ground sufficient for a definition. In the first place, the uniformity of systematization in scholasticism

1 History of Philosophy, p. I98 (Paris, I 883).

2 Dictionary of Philosophy and Psychology, published by Baldwin (Macmillan, I9O2), v. 2, p. 492, under the word "Scholasticism," signed by $J$. Dewey. Later on we shall meet yet another meaning given to the word in the same article.

${ }^{3}$ Willmann, Geschichte des Idealismus, t. 2, section 67 , numbers 2 and 4 (Brunswick, I 896). We can understand how historians who take this point of view can call J. Scotus Eriugena " the first scholastic," the palatine philosopher having systematized earlier and better than St. Anselm (see next Section). Cf. Willman, ibid., p. 339. 
does not embrace the order of the questions treated, but regards principally the line followed in the study of any definitely fixed question (18 and 19). Then, too, such systematization is not peculiar to scholastic philosophy, and hence the definition inspired by it no longer suits "omni et solo definito." In fact, whether they deal with questions of theology or of civil or canon law, or with scientific questions, or with disciplinary controversies or eren simple questions of actuality, the publicists of that age had recourse to the same methorls. Speaking of the dialectic method inaugurated hy . berlard. M. Langlos writes: "This manner of teaching and exposition. well suited to develop a taste for argumentation and for the formal 'dispute,' spread rapidly through all Northern Europe. and into Italy ; for the Inecree of Gratian of Bologna, entitled comcordentien discordantium canonum. was no less deeply influenced by the Sic et Non than the Lombard sentences were." When Godfrey of Fontaines discusses the point of Feudal law which used to give rise to so many quarrels between lords and peasints. "utrum licet habere columbarium." he follows the same plan. and uses the same distinctions as when he studies "utrum mundus possit esse ab xeterno." It was a plan deliberately chosen: it is in keeping with the logic of the scholasties who subject not only philosophy, but every branch of human knowledge, to the same laws of method (17). In a word. to define scholastic philosophy by its methods is to mistake its labels for its contents: it is going around the edifice and describing its facade instead of visiting its interior. All the definitions we have hitherto examined present this common defect, that they stop short at the formal setting of the doctrine without penetrating to the doctrine itself contained within this setting.

${ }^{1}$ Lavisse and Rambaud, Histoire générale du 4 the siicle "nos jours, t. 2, pp. 550 and $55 \mathrm{I}$. 
SECTION 6.-SCHOLASTIC PHILOSOPHy AND MEDIEVAL PHILOSOPHY.

26. People have been accustomed to understand by scholasticism the sum total of the philosophic thought of a distinct epoch, and so to identify scholastic with medieval philosophy. Accordingly, all who lived and philosophized in the Middle Ages would be scholastics. This identification, found already in Cousin, ${ }^{\mathrm{I}}$ and openly admitted by Hauréau, Ueberweg-Heinze and Erdmann," is formulated in the following terms by M. Picavet: "Scholasticism, in the strict sense of the word, denotes the speculative researches of the ninth to the fourteenth centuries, in which, side by side with certain scientific data, philosophy and theology predominate." 3

The origin of this identification is easily accounted for. Historical studies in medieval philosophy are of a very recent date. It was customary to regard all the speculations of that age as a homogeneous whole, of a very vague and general character; and to apply to that whole the no less vague denomination of scholasticism. That description has been retained even by those who have shown by their works that the homogeneity of medieval thought is only apparent, and, on closer examination, admits of considerable divergences.

One all-important fact has been brought to light. During the Middle Ages there flourished manifold

${ }^{1}$ Cousin, Histoirc générale de la Philosophie (Paris, I864), p. 189. Cf. Cesar Cantu, Storia universale. Documenti (Torino, 1863), t. 2, p. 295: "La scolastica. . . non è . . una forma particolare della filosofia, ma propriamente la filosofia di un certo tempo."

" Hauréau entitles the history he has written of medieval philosophy : Histoire de la philosophie scolastique. So also Ueberweg-Heinze, op. cit., p. 146; Erdmann, Grundriss der Geschichte der Philosophie (Berlin, I896), t. I, p. 263. All the Middle Age philosophers and philosophies studied by those authors, are called scholastic. Nowhere do we find in them a classification of medieval systems into scholastic and non-scholastic, nor any trace of such classification.

${ }^{3}$ Picavet, Abélard et Alexandre de Halès (Paris, 1896), p. 3. 
systems of philosophy, some inter-related, others foreign to one another; and, among these latter, many were involved in inevitable conflict by the assertion of contradictory principles. Vieved in its totality. the philosophical output of the Middle Ages may be compared to a chaos, a mosaic of systems: there is no doctrinal unity to be found in its productions. That is the only plausible meaning to be found in such statements as that "scholasticism, as generally understood, is less a system than a chaotic componind of all systems.

After all. We should naturally expect such a state of affairs. The Mirdle lges, in the wider sense of the term, comprise the first fifteen centuries of our era: in the narrower sense of the historr of ideas, they embrace the period extending from Charlemagne to the Renaissance (ninth to fifteenth centuries). It is not likely that, during such a long lapse of ages, humanity would have settled down contentedly into accepting one single philosophical conception of the universe, the scholastic conception, and that not a discordant voice should have marred the intellectual concert. Such a phenomenon would have been unique in history. The more we study any given civilization, the more clearly does it present itself to us as a complexus of thought-movements, which meet and combine, or conflict and repel one another.

In literature as in painting, in politics as in religion, in science as in philosophy, there have been at all times dominating. but never monopolizing systems. The romantic and the classic in art, in politics the democratic and the aristecratic, in religion the heterodox and the orthodox, have been ever and always at war; and it was not in the region of

${ }^{1}$ Lindsay, Scholastic and Medicaral Philosophy (Archio f. Geschichte dir Philosofhie, Ioor, p. 43).-Cf. Hauréau: "All systems are represented in Scholastic Philosophy, which, therefore, is not itself a system " (I)ictionnaive des sciences thilos., under the word Scolastique). 
philosophy that the struggle lacked determination during the Middle Ages.

This new fact which ought to dominate a history that deals, not with a mere nomenclature of philosophical names and events, but with the logical evolution of ideas, must likewise inspire the terminology by which divergent systems are to be designated. Beyond the problem of terminology arises that of the interpretation itself of Middle Age philosophy. The two problems are inseparable. But as soon as we set ourselves to the task of determining the relations between scholastic philosophy and medieval philosophy we are brought face to face with an alternative: Fither we must make the term "scholastic" a huge label to cover the whole complex collection of medieval systems, like the trade marks of promiscuous merchandise, or we must adopt an a potiori denomination by restricting the meaning of the word to one of those systems, or to one group of systems, to the exclusion of all the others. It is the second alternative we stand by, ${ }^{1}$ both because it enables us to avoid serious difficulties, and more especially because it puts us on the way to a right interpretation of two or three great facts that dominate the history of medieval philosophy, and which would be otherwise inexplicable.

28. Let us first refer to some of the difficulties that arise from confounding scholasticism with all medieval philosophy.

(a) Such identification is arbitrary. That the expression "medieval philosophy" should describe a collection of doctrines is intelligible. But it is hard to see why "scholastic philosophy" should be synonymous with medieval philosophy.

${ }^{1}$ Setting out from a different point of view, Windelband, we are glad to see, arrives at the same conclusion: Es erscheint somit nicht angemessen, der mittelalterlichen Philosophie den Gesammtnamen der "Schololastik" zu geben. Geschichte der Philosophic (Freiburg, i. B. 1892$),$ p. 210. 
(b) To adopt such an identification, by applying one and the same name to different things, would be to approve of the vague notions with which people have heretofore been satisfied.

The fact is that no matter what side we turn, the doctrinal horizon grows ever larger. Western philosophy resolves itself into manifold systems. From the eleventh century onward, we find a clearly marked pantheism, renewed from the Neo-Platonic, in conflict with many more or less complete forms of Aristotelian individualism. John Scotus Eriugena (ninth century) and Anselm of Canterbury (10331139) are at the opposite poles of thought, and they personify the work of the ninth to the eleventh centuries. In the twelfth century, Alanus of Lille combats the psychology of the "athari and the Albigenses, who are propagating the ideas of Incretiu, and Epicurus. The influrnces of John Scotus Eriugena are emphasized in the pantheism of Chartres; still more amongst the Amauritian pantheists. who are openly attacked (towards 1210) by a scholastic, Garner of Rochefort; and in the pantheistic materialism of David of Dinant (late in the twelfth century), of whom St. Thomas writes: "Frror fuit Davidis de Dinanto, qui stultissme posuit Deum esse materiam." "This monism, under all its forms, is in irreconcilable opposition with the philosophy of an Abelard (1079-1142) or of a John of Salisbury (thirteenth century).

With the thirteenth century commences the long drawn out struggle between the Averroïst system, which had already found its defenders, and the great systems to which Albert the Great, Bonaventure, Thomas Aquinas and Duns Scotus have attached their names. This fight against Averroïsm passe's through various phases, some of them very exciting.

'Summa Theologica, I"lia Pars, q. 3, a. S, in corf. 
In the University of Paris it is taught in " the schools of the Rue de Fouarre," whilst in the neighbouring schools every effort is made to refute it and to undermine its influence. The Averroïstic leader makes a direct attack on the leader of the opposing party. In 1270, St. Thomas Aquinas writes his treatise De unitate intellectus against the De anima intellectiva of Siger of Brabant. Along with the doctrinal controversy, both parties carry on a campaign of personalities and intrigues, ending in official prohibitions, periodically renewed, and all alike fruitless. Averroïsm survives the thirteenth and fourteenth centuries: in the universities of Northern Italy during the fifteenth century, the name of Averroeis is on every tongue; and it is to hear his theories against personal immortality and a future life that enthusiastic audiences hail the arrival of their professors with cries of "Speak to us on the soul, tell us about the soul." In proportion as we advance from the thirteenth century the conflict of ideas becomes more heated, until finally the combined forces of the Renaissance-the German mysticism, the theosophy of Bovillus and of Giordano Bruno, the Platonism of Bessarion and of Marcilius Ficinus, the Pseudo-Aristotelianism of Achillinus and of Niphus, the cabalistic Pythagorism of Reuchlin, and various other doctrines-make a fatal attack on the philosophy whose sway had extended over so many centuries.

Would it not foster confusion of ideas to identify the one Scholastic Philosophy with the numerous and irreconcilable philosophies of the Western Middle Ages ? "A Philosophy" ought to mean one system; it ought not to mean a chaos of systems (11.) It is agreed to describe as scholastic the philosophy professed by certain great men of thought, by an Anselm of Canterbury, an Alexander of Halès, a Bonaventure, a Thomas Aquinas, a Duns Scotus-by those exactly 
who, alone from amongst the crowds, emerged like towering mountain tops from the mist and darkness of the Middle Ages. And is it not an abuse of received language to apply the same family name to men who waged open war against the most cherished convictions of those doctors ${ }^{1}$ ?

Nor is that all. Besides the Western philosophy, other currents of jdeas pass down the Middle Ages, pursuing a course of their own; and these may not be neglected: Brzantine philosophy on the one hand, and on the other the Asiatic philosophies.

Banished from Athens and Alexandria, Greek philosophy was transplanted into the capital of the Eastern empire, and flourished there throughout the Middle Ages. Its development was slow and irregular like the Byzantine genius itself. Although Byzantium could gather the inheritance of the ancient wisdom in its own native tongue, yet the infiltration of Greek philosophy was less marked there than in the Arabian civilization, where the Greek inheritance was soon incrusted with a large Arabian deposit. But withal, Byzantine philosophy is the product of a distinct civilization. Compare, in the ninth century, the patriarch Photius with the palatine Scotus Eriugena: or, in the twelfth, Michael Psellus, professor at the Academy of Constantinople, Prime Minister of Michael Parapinakes-with John of Salisbury, familiar figure in the Paris schools, trusted

\footnotetext{
${ }^{1}$ It is likewise this identification of scholastic with medieval philosophy that has led almost all historians of Middle Age philosophy to put John Scotus Eriugena among the scholastics. See, for exampie, Penjon, op. cit., p. I75; Rehmke, Grundriss der Gesch. d. Philosophie, Berlin, r896, p. 89 ; 'Cherweg, op. cit., p. I 50. " Remarkable thing! Not only is Scotus Eriugena the father of scholastic philosophy, but he even seems to comprise in his work all its developments." St. René Taillandier, Scot Evigène et la philosophie scolastique, Paris, I 843. Nothing could be more deceptive than such a classification, for we find in J. Scotus Eriugena the beginnings of currents of icleas which enter into conflict with the doctrines of Anselm, Alexander of Hales, Thomas Aquinas, Duns Scotus, etc., etc. J. Scotus Eriugena is, in our opinion, the father of antischolasticism. See our Histoire de la philosophie médiérale (Louvain, Igoo), p. I82.
} 
friend at the Tatican and at the English Court; and you will vividly realize how vast a difference there is between the pompous and oftentimes empty genius of Byzantium, and the cold, speculative reason of the West.

And what is to be said of the bundle of various doctrines gathered together under the title of Asiatic philosophy? - the Armenian tradition, illustrated by David the Armenian; the current of Persian ideas initiated by the Greek philosophers, refugees at the Court of Chosroes Nuschirwan, and at the academies of Nisibis and of Gandispora; Syrian culture so flourishing in the schools of Resaina, of Chalcis and of Edessa; and, above all, the brilliant outburst of Arabian peripateticism both in Asia and in Spain? All those peoples, who are the heirs of the Greek ideas, have their own distinct turn of philosophic thought, resulting from their constitution, from their scientific relations, from their religious, political and social institutions, nay, even from their very climate and physical surroundings.

Now, during the whole period prior to the thirteenth century, the Western, the Byzantine and the Arabian currents developed in absolute independence: Paris, Byzantium, and Bagdad are three intellectual centres unknown to one another; and we find in the ninth century three personalities-John Scotus Eriugena, Photius, Alkendi-each professing a distinct philosophy apparently without a suspicion that any other existed. Are all those philosophies to be integral parts of the scholastic philosophy ? And must we also admit the Chinese and Indian philosophies, since in the land of Buddha all philosophical tradition had not yet quite disappeared in the Middle Ages ?

The truth is that those syntheses, which abound in the Middle Ages, are so many irreducible products. Even if particular theories are found to be identical in two or more of the various opposing systems-- 
as, for example, the solution of the universals' problem by Avicenna and by St. Thomas-they show, notwithstanding, the general impress of each system as soon as we cease to regard them separately and place them in their respective contexts. And that is why, from a doctrinal point of view-which alone considers a philosophy by that which it has in it philosophical-we cannot hope to find, in the medieval variety of systems, Western, Byzantine, or Asiatic, a common spirit which might serve as basis for the one common title of "scholastic." To discover characteristics common to so large a group, we should be obliged to fall back upon extra-doctrinal, or, in other words, upon non-philosophical notions; upon those vaguer elements which have their value indeed as marks of a civilization, but do not afford an adequate basis for a philosophical definition. So much we admit to be just and accurate in a criticism with which M. Picavet has honoured us, and in which he pleads for the identification of two titles which we feel bound to keep separate: "Scholastic thus" becomes the exclusive epithet of those who, in philosophy, hold Thomist doctrines or doctrines akin to Thomism ; just as Roman Catholic is applicable only to those who give full and complete adherence to the theology of St. Thomas. But those classifications are equally arbitrary. There are scholastics amongst the Neo-Platonists, or in the time of Kant, Hegel and Cousin, in this sense that they propagate or imbibe their doctrines in the schools . . . but in the Middle Ages . . . all alike, whether orthodox or heterodox, . . . are, accordingly, scholastics. And this is not a mere etymological and esoteric definition: it implies characteristics to be found in them all, and distinguishing them from all other philosophers. 
Christians of the East and Christians of the West, Arabians and Jews alike, belong to a theological epoch, and give a systematic conception of the world and of life, in which God and Immortality hold the foremost place, and which embodies in varying proportions, religion and theology, Greek and Latin philosophy, especially Neo-Platonism, together with the scientific affirmations of antiquity and of contemporary explorers.".

29. But if, on the other hand, we restrict the meaning of the term "Scholastic Philosophy" to one medieval system, tautology and equivocation disappear. Far from falsifying, we should be only fixing the fluctuating meaning attached to the epithet "scholastic" at a time when no attention was devoted to the opposition movements that filled the Middle Ages.

Names are conventional substitutes for things. When a thing denoted by a name is simple and single, the name is intelligible to all and adequately fulfils its function as substitute. But as soon as we discover that apparent simplicity disguises real complexity, we must improve and enrich our vocabulary. So, for example, the terminology of biologists grew and developed according as the microscope revealed new bodies in a cell that was first believed to be of a homogeneous nature. The historian of medieval philosophy yields to the same necessity. By giving different names to different systems he is only respecting the law that governs the development of scientific nomenclature.

We may add that the choice we shall make, when we come to select the particular medieval system that deserves to be called the scholastic system, will be in keeping with the language of tradition. It will be rightly held that, ceteris paribus, those who

1 Picavet, a propos of our Histoire de la philosophie médiévale, in the Reiew Le Moyen Age, 1902, p. 34. See above, p. I6. 
have been calied the princes of scholasticism by the custom of centuries, and are still so called at the present day, have the first right to an a potiori denomination by retaining the title they have always enjoyed. Let us respect that custom. The term "scholasticism," applied to the doctrine of their adversaries, is an abuse of language.

And this permits us also to. point out that our suggested solution of the above probleni of historical terminology, not only avoids serious inconveniences, but also explains several important facts of history which we may summarize as follows:-There is " phitosophical synthesis common to a group of the leading doctors of the W'est.-That synthesis does not steritize originality of thought in the case of amy one of them.-It is predominant in the Widdle Ages: to it belongs the name of "Scholastic Philosophy."

30. There is a synthesis common to a group of the leading doctors of the West, amongst whom may be mentioned the prominent names of Anselm of Canterbury, Alexander of Halès. Thomas of Aquin, Bonaventure, Duns Scotus, William of Occam. and a long line of other distinguished personalities. These men, in fact, show very pronounced-family resemblances; they are in agreement on a considerable number of fundamental theories-those precisely that form the essentials of a system, because they have for object the capital problems of all philosophy (11).

That synthesis is not the work of one day, or of one man. It was not born of the genius of an Albert the Great, or a Thomas of Aquin; only centuries could have built up such a vast body of doctrine as scholasticism. Sparse at first, and scattered through many glosses and commentaries up to the eleventh century, scholastic thought became conscious of its power for the first time with St. Anselm of Canterbury. The logical controversies 
of the time soon led to metaphysical debates. With Abelard, who gave such an impetus to the problem of the universals, psychological themes began to assert themselves; and it can be said that in the last years of the twelfth century, the works of Alanus of Lille and of John of Salisbury indicate, by their synthetic tendencies, the approach of an age of maturity. Neither of these two writers knew of the rich Arabian literature that was to communicate to scholasticism, about ten years later, such an incomparable splendour. We may ask ourselves how it would have fared with scholasticism, had it pursued an autonomous development, left to its own forces, and deprived of all contact with the rich inheritance of ideas bequeathed by the Arabians. Perhaps it would have brought forth with greater labour, but also with greater glory, the masterthinkers of whom it is so justly prond.

However that may be, less than thirty years after the appearance of the new Aristotle in the West, Alexander of Halès, and more especially Albert the Great, achieved a systematization of ideas, such as the widest circulation of the works of any one philosopher would have been unable to call forth in a medium not prepared to receive it.

The unity of scholasticism is seen even in the fifteenth century, the age of its decline, when the regents of the Italian universities rise up in arms against the Averroïstic materialism. It reappears yet once again, during the sixteenth century, in the revival so nobly attempted by such men as Suarez, Vasquez, and the professors of the college of Coimbra.

At all times we find its common patrimony defended against invaders : from the very beginning the fight goes on ; and this defence, energetic and triumphant in the centuries of its greatness, cowardly and disastrous in the ages of its decay, accounts for the 
fact that men like Thomas of Aquin, Bonaventure, Henry of Ghent, whilst engaged in interminable controversies among themselves about special questions, join hands at once whenever there is question of defending their common convictions against the common enemy.

31. The unity of the scholastic system does not sterilize originality of thought in its various representatives.

A monument in ideas, scholasticism resembles those monuments in stone that were erected during the same period, and had several generations of men as their architects and builders. The comparison is an apt one: the directive rules of the corporation left every stone-cutter free to follow his own artistic inspirations in the executing of the work entrusted to him. That is why the Middle Ages, while preserving unity of plan in those cathedrals, could yet invite the very lowliest even of its artisans, to contribute something or other stamped with the mirrk of his own distinct personality.

In scholastic philosophy, similarly, we meet with unanimous agreement in the solution of vital, essential questions-a certain doctrinal minimum which differentiates the scholastic system from that of a Plato, of a Leibnitz, or of a Kant.

But if unity of principle asserts itself in the solution of individual problems, it does not prevent shades of difference, variety in development, and diversity of interpretation: therein lie the differences between the syntheses of an Alexander of Halès, a Bonaventure, a Thomas Aquinas, a Duns Scotus, a William of Occam.

It is needless to add that the common element of scholasticism, apart from its historical setting, is the product of an abstraction, and that the living reality was always this or that definite scholasticism. This fact must never be lost sight of by anyone 
who would follow fruitfully the development of the scholastic controversies. And bence it would be misconceiving the debates of the time to imagine a clan of monks and seculars quarrelling over trifles. It is only jonorance of the scientific surroundings in which scholasticism developed that could have gained currency for those unreasoning prejudices that caricature it. Nothing could be more remote from barren hair-splittings than those episodes in the clash of scholastic systems.

One single example will suffice. When St. Thomas came to teach in Paris, towards 1269-1271, he fell foul of the older scholastic school of Alexander of Halès and St. Bonaventure, to which he opposed a new peripateticism, better developed and more logical. While agreeing with his illustrious opponents on all the fundamental theses of philosophy, he separated from them on a whole crowd of questions that were relatively secondary, but yet sufficient in number and importance to give to his scholasticism quite a characteristic impress. To plurality of forms in the individual, he opposed unity of substantial principle; to the theory of the rationes seminales, that of the privatio ; to the hylemorphic composition of spiritual substances, the doctrine of subsisting forms ; to the Augustinian theory of the identity of the soul and its faculties, that of their real distinction, etc. It is precisely in that divergence of views that the perspicacity of the innovating genius of St. Thomas reveals itself. But his contemporariesnot excepting his brethren in religion-heard his teaching with a deep distrust. The documents of the time introduce us to a series of public debates, personal intrigues and official prohibitions. We witness a general mêlée which provokes quite a storm of pamphlets and polemical works, and brings on the scene all the striking personages of the time; a giant conflict of ideas, forming a perfect parallel 
with the most exciting episodes in the history of modern philosophy.'

Those discussions show that there were various sections in the scholastic family, and that some amongst them surpassed others in their unity of doctrine and in their understanding of fundamental principles.

They also reveal certain weaknesses.

32. Oftener than once, in fact, in the course of its history, scholasticism witnessed deriations from its principles. Enthusiasts, like Raymond Lully, in far exaggerated the compenetration of theological and philosophical truth as to lead philosophy to the confines of theosophy. Others, like Roger Bacon. too independent or too narrow, made compromises with Averroïsm, or emphasized the rights of empirical observation so far as to give an apparent footing to modern historians in search of precursors fur positivism. Such men as those were far from being enemies of scholasticism; they tarnished its purity. but in good faith. Hence it is only right to make a place apart for those "rash disciples." If the scholastics are a party, is it any wonder that the party should have its troublesome members whom it distrusts, as well as its open adversaries on whom it wages an unending war?

33. Finally, the above-mentioned synthesis is dominant in the Middle Ages. In the West, it can lay claim to the greatest names. It can also vindicate for itself a vast majority of all the suffrages; for, prior to the twelfth century, most of the philosophers are preparing it in various ways, and subsequent to the thirteenth century, it still draws around it hundreds of advocates who perpetuate and popularize its fundamental solutions.

\footnotetext{
${ }^{1}$ We have published, with a historical introluction, on of the most curious of those products of passing events, the controversial treatise De unitate forma, of Giles of I.essines (rol. i. of the collection Les Philosophes du moyen age, edited by the Institut sufricur de philosophic, Louvain, I901).
} 
On the other hand, Eriugenian Pantheism and Latin Averroissm, the two chief forms of the opposition, fall into a secondary place, if we compare their prestige and value with those of the great synthesis they tried to undermine.

From which we conclude: Scholastic Philosophy will denote, not all the philosophies of the Middle Ages, but one definite synthesis, the most widespread, the most ably defended, and the best constructed, in the intellectual history of the Western Middle Ages. ' It is, if you will, its philosophy par excellence, but not its only philosophy.

34. Thus to fix the meaning of scholasticism is to fix, at the same time, that of anti-scholasticism; that is to say, of those systems that opposed the fundamental principles of scholasticism, or of certain conceptions animated by other principles irreconcilable with the former ones. If one of the terms is legitimate, both are. "The distinction between scholasticism and anti-scholasticism seems arbitrary (writes M. Valmy), at least for the time previous to the thirteenth century and the formation of the doctrinal synthesis. It leads to representing Scotus Eriugena as the adversary of a system that was not yet in existence in the ninth century, and to separating masters and disciples, as in the case of Thierry of Chartres and Bernard of Tours." 2 No

' In his Histoire de la philosophie, vol. i. (I896), M. Elie Blanc says, on the subject of scholasticism: "It is not precisely a system, for most systems were upheld by some people or others during the Middle Ages; and it is evident, moreover, that scholasticism profits much by all that is best among the philosophers and their schools," p. 378 . We confess we are unable to understand M. Blanc's reservations, for he himself writes, p. 381: "The scholastics succeeded in demonstrating a collection of truths closely allied with one another: in a word, they built up a system, without, however, falling a prey to the systematizing spirit." Does the author not contradict himself ? He goes back on the same line of thought in the Universite Catholique (1902, p. 145), to contrast his view with the theory developed in the text above.

In a criticism of our Histoive de la philosophie médiévale (Études, published by the Jesuits, 1902, p. 266.) 
doubt the scholastic synthesis was not fully finished until the thirtecnth century, but it was in process of formation in the ninth and tenth centuries. in the glosses of a Rhaban Maur or an Eric of Auxere. But the monistic principles of J. Scotus Eriugena were directly opposed to the individualistic realism that lay hidden in those glosses and treatises, and developed as a matter of fact into doctrines whose hostile character hardly eseaped the notice even of contemporaries. Then as regards masters and disciples, do they always follow the same paths? And if the disciple turns his back on the route followed by his master, must they not inevitably arrive at opposite points? And if so, how are we to avoid placing them in different categories?

On the other hand, M. Delacroix recognises the justice of a classification of medieval systems into scholastic and anti-scholastic; but he adopts it for reasons of another order: "We beliere," he writes, "that the division is a correct one. It is easr to detect, throughout all the periods of medieval philosophy, two great currents moving in opposite directions: but the opposition springs less perhaps from the philosophic content of the systems than from their attitude towards dogma and their relations with theology. We think, in opposition to II. De Wulf, that the essential characteristic of the systems he calls antischolastic, is their spirit of independence and of freedom in regard to dogma. . . . The distinction between scholastic and anti-scholastic systems is a precious one, but to us it does not seem appropriate except as referring to the spirit rather than to the content of each of those philosophies." I II. Delacroix has recourse to a new criterion : the dependence or the independence of the respective systems in regard to dogma.

'La philosophie médicuale latine jusqu'au Itme sicle (in the Revue de synthèse historique, August, 1902, p. IO2). 
This brings us to a new order of researches in which we shall encounter the opinion of the learned professor of Montpellier.

\section{SECTION 7.--SCHOLASTIC PHILOSOPHY AND SCHOLASTIC THEOLOGY.}

35. Of all the current notions of Scholastic Philosophy assuredly the most widespread is the one inspired by its relations with Christian dogma. Some would have it the handmaid, others the spouse or honoured working companion; but for all alike, scholasticism is simply philosophy placed under the power or under the guidance of Catholic theology. To believe those who understand this subordination in the sense of a veritable servitude, medieval philosophy was built up simply and solely to defend Catholicism. The extreme language employed by such authors to express that dependence, exposes them to the unfortunate confusion of ideas already referred to ; and many have been unable to avoid it (5). "The Middle Ages," says Cousin," "mean simply the absolute reign of the Christian religion and of the Church. Scholastic philosophy could not be anything else than the product of thought in the service of the reigning Credo, and under the supervision of ecclesiastical authority." The same verdict, slightly toned down, is given by Ueberweg-Heinze : "Scholasticism is philosophy in the service of the existing Church doctrine, or at least in such dependence on it that, in a common domain, the latter holds the ruling place as supreme standard." " And in like manner Freudenthal writes: "However lively may

${ }^{1}$ Histoire générale de la philosophne (Paris, I 864), p. I89.

2 "Die Scholastik ist die Philosophie im Dienste der bereits bestehenden Kirchenlehre oder wenigstens in einer solchen Unterordnung unter dieselbe, das auf gemeinsamen Gebiete diese als die absolute Norm gilt." Ueberweg-Heinze, op. cit., p. I $q^{6}$. 
have been the debate concerning the nature and meaning of Scholasticism, one thing was agreed upon by all, friends and foes alike: its complete subordination to Church dogma." I With these very similar definitions, which might be quoted indefinitely, let us finally compare the opinion of one of our most. notable historians, Windelband. He regards scholasticism as a " scientific systematization of Church doctrine, fully expounded, examined and developed." 2 From this so-called slavery. which appears to have been acknowledged even by scholasties themselves (Philosophia ancilla Theologiar), people generally concluded that the rights of reason were violated, and that the Viddle Age intellectual movement was, as a necessary consequence. completely sterilized. ${ }^{3}$

Side by side with this first group of historians. there are others who keep closer to the real facts of the time. These latter writers speak of a " collatboration" or "union" of philosophy and theologr, in this way laying claim to esteem and consideration as rightly due to the former, and demurring to the despotism of the latter. "The deepest and widest characteristic of scholasticism." writes Gonzalez, " is the union of philosophy with theology, or, to

1 " Wie heftig der Streit über Wesen und Bedeutung der Scholastih auch geführt ward, eines war von freund und fieind zugestanden: ihre vollständige Ahü̈ngigkeit von der Kirchenlehre." Frendenthal, Zur Beurtheilung der Scholastil (Archiv für Geschichte der Ihilosophie, Bd. 3, p. 23).

2 "Der Augustinismus concentrirt sich um den Begriff der Firche; für ihn ist die Aufgabe der Jhilosophie in der Hauptsache darauf gerichtet, die Kirchenlehre als wissenschaftliches System darzustellen, zu begrïnden und auszubilden: insofern als diese Aufgabe verfolgt, ist die mittelalterliche Philosophie die kirchliche Schulwissenschaft, die Scholastik." Windelband, op.cit., p. 209. In Baldwin's Dictionary of Philosophy and Psychology (Cf., p. 35, n. 2), Dewey speaks of scholasticism as "The name of the period of medieval thought in which philosophy was pursued under the domination of theology, having for its ain the exposition of Christian dogma in its relations to reason."

3 Frendenthal (op. cit., p. 23), criticising a work of Ritter (Geschichte dev Philosophie, Bd. 7, p. I23), notes as a "singular and incredille" opinion of the author, the thesis maintaining that the Church of the Middle Ages did not interferc in any way with freedom of thought. 
express it otherwise, of human and natural science with divine and revealed science." "Two scholars of high repute in Germany, Erdmann ${ }^{2}$ and Otto Willmann, ${ }^{3}$ and in France two others, Blanc ${ }^{4}$ and Picavet, have adopted the same view. The latter has candidly protested, in the name of historical truth, against the fable that scholastic philosophy was subjected to any excessively rigorous surveillance. "The works of the scholastics," he says, "bear witness to a collaboration between philosophy and theology." ${ }_{5}$ We find the same idea developed in a study presented by the same writer to the International Philosophical Congress (1900), on "The Value of Scholasticism." After emphasizing the essentially theological character of the Middle Ages, M. Picavet goes on to say : "But just as in positive or metaphysical epochs-to use the formula made current by Comte-there is room for religion, or for theology which is its systematized conception, so, in like manner, the Middle Ages had their philosophical conceptions, as well as researches and theories of a scientific character. Accordingly, scholasticism is a mixture of theological, philosophical and scientific doctrines. Nor must we imagine that the famous formula 'Philosophia (comprising Scientia) ancilla Thedogice' represents as accurately, as succinctly the mut ral relations of the three factors. Hagar, the han maid of Abraham and the type of philosophy, was considered by the Moors as the equal, if not the sup ior, of Sarah, the type of theology. The Christian themselves regarded her as a spouse, and not as

'Gonzalez, Histury of Philosophy (French translation, Paris, Lethilleux) vol. ii., p. 4ig.

20 . cit., vol. i., sections 150 and $\mathrm{I}_{5} \mathrm{I}, \mathrm{p}$. 264 .

3 " Es ist also ein durch die Ideen und zuhöchst durch den Glauben orien erter Realismus, der die echte Scholastik charakterisiert." Otto Willnann, Geschichte des Idealismus (Brunschwig, I 896), vol. ii., p. 323.

+ listoire de la Philosophie (Lyons and Paris, 1896), vol. i., p. 381 .

" Report published by the Revue de métaphysique et de morale, I90o, p. $65 \%$. 
a servant in the lower and ordinary sense of the word. Then, too, St. 'Thomas sometimes uses the word vassal instead of serumt: and we know that some vassals were the peers or equals of their suzerains. Moreover, if we examined the srstems, the theological or philosophieal works of the time, we should sometimes find ourselves very much embarrassed as to whether philosophy or theology had the main part in them. Of this we can very easily find a practical proof by studying St. Thomas's commentary on the Sentences of Peter Lombard-a commentary which formed a sort of first adition of the Summa Theologica." For the rest, it matters little, from our present point of view. what those witers may think about the value, scientific and doctrinal, of that union of theology with philosophy. Cardinal Gonzalez, Erdmann and Willmann are convined of its fecundity. Picavet does not take sides. Others, as Eucken, for example, infer the bankrupter of the medieval conception - the temple of nature built by Aristotle being so different in style of architereture from the temple of grace erected by christ, that their juxtaposition (Nebeneinander) resulted necessarily in an incongruous, uninviting edifice, altogether lacking in unity of design."

36. Some authors submit the second class of the above-mentioned formulas to an ingenious widening process, like what we have already encountered (10) in reference to "scholasticism." Just as scholasticism was the proper title of any and every " daughter of the schools," so might it be similarly applied to every philosophy subject to any dogma. Tho scholasticity of a system would be measured by the

1 Picavet, l.a calcur de la sculustique, in the Library of the International Philosophical Congress, vol. iv. (Taris, 1902), 1p. 24t-2 $4^{(\text {). }}$. Cf. Picavet, Le moyen age, etc., p. cit. This latter study is published in a volume called Entre camurades (Paris, I901).

${ }^{2}$ Thomas von Aquino und Kant. Ein Kampf zweier Holten. In the kantsudien, 1901, vol. vi., part I, Pp. I-19. 
degree of its subjection. It is in this sense that M. Carra de Vaux says of the Arabian philosophy that the capital problem in the minds of its cultivators was the scholastic problem, meaning the alliance of philosophy with the Koran.' And he is able to say of Alfarabi that he "jumped clean across " the scholastic problem." In like manner, too, M. Blane writes: "These various scholasticisms would consist in the agreement of the philosophies in question with such and such religious creeds.

The spirit of scholasticism must be sought in this very accord of faith and reason, rather than in this or that abstract, ill-defined system, or, indeed, even in any definite system." 3 Dogma thus determines scholasticism. The Middle Ages produced a Mahommetan scholasticism in the East, as well as a Catholic scholasticism in the West. The Vedanta embodies a Brahminical scholasticism, the writings of the Jewish Philo, a Jewish scholasticism, ${ }^{4}$ and nearer home nothing would hinder us from speaking of a Protestant scholasticism.

Now, in order to discuss the grounds of those definitions, and to sift the true from the false, we must give some outline of the code of relations established in the Middle Ages between philosophy and theology. We shall find these relations in the parallel formation of both sciences, in their pedagogical organization and in the subordination and co-ordination of their doctrines.

37. Amongst the problems of scholastic philosophy, very many had their origin in theology in this sense, that they arose on the occasion of theological controversies. In the ninth and tenth centuries, the

"Avicenne ("Les grands philosophes," Alcan, Paris, I901), p. 273.

2 Ibid., p. I 16.

${ }^{3}$ Ibid., p. I15. Compare with this quotation the statements referred to above, p. $5 \mathrm{I}, \mathrm{n}$. I.

${ }_{4}^{4}$ The expression used by Zeller, Die Philosophie aer Griechen, vol. 3. p. $34 \mathrm{I}$. 
quarrel about Predestination raised the question of Human Liberty and its relations to Divine Providence and Divine Justice; the Paschasian controversy on the Real Presence of Jesus Christ in the Eucharist brought forth dissertations on Substance and Accident; the dogma of the Trinity suggested discussion on the notions of Nature and Person and Individual; Transubstantiation and the Divine Simplicity provoked the study of Change. But all that is not saying that the two spheres of research were confounded $(5)$ : for the genesis of a philosophical controversy is one thing, its intrinsic value and significance quite another.

Scholastic philosophy and scholastic theology ran parallel in the Middle Ages; they went through it common rhythmical morement of progress, culminirtion and decay.' If the fortunes of the two sciencess were so intimately bound up together, it is simply because religious faith inspired the medieval civili. zation with a teaching system that was sui generis. a system whose fundamental principle was the convergence of all human knowledge towards the study of theology. This abiding tendency is visible in all the programmes of studies that were in use in the monastic and abbey schools. Everyone's ambition, after studying or while continuing to study philosophy, was to become a theologian. Later on, in the universities, degrees in arts were a necessary qualification for degrees in theology. To be a bachelor, licentiate, or master in theology, was the end; to study philosophy, the means-just as at the present day, in the regime of many universities, a diploma in philosophy and letters gives access to the other scientific branches of study. The honour rendered to the masters of the sacred faculty is an index of the esteem in which the science of theology was held. The theologians took precedence not only of the

${ }^{1}$ Cf. Willmann, op. cit., vol. ii., section 68, pp. 342 and foll. 
"arts" but also of the "law" and of the " medicine" professors. One should examine in detail the minute prescriptions which laid down the uncontested prerogatives of the sacred faculty, at Paris and elsewhere, to see how faithfully that organization of studies reflected the spirit of the whole medieval society. ${ }^{\text {' }}$

38. The relations just referred to are extradoctrinal; they arise from the genius of medieval civilization, from a peculiar organization of public and private life. But we also find a collection of laws which express relations of subordination and coordination between the contents of the two sciencesrelations, too, that are just as clear in the minds of scholastics as the very distinction itself between theology and philosophy. Those laws had been already tacitly admitted by the philosophers of the early Middle Ages, were expressed in main outlines by St. Anselm, and were finally codified in the introductions to most of the great theological Summe of the thirteenth century.

Scholastic philosophy is recognised to be subordinate to theology. This dependence-unanimously admitted though differently interpreted by all the historians of the Middle Ages-is summed up in a formula which needs some explanation: The subordination is material, not formal. That is to say: while the two sciences preserve their formal independence, or independence as regards the principles that direct their investigations, there are certain matters in which philosophy cannot contradict the conclusions of theology. The medieval scholastics justified this subordination, because they were profoundly convinced that in Catholic dogma they found the word of God, the infallible expression of the truth. Supposing to be admitted as certain any

${ }^{1}$ See on this subject, Thurot, De l'organisation de l'enseignement dans l'Universite de Paris (Paris, 1850 ), and the documents published by Deniflé and Chatelain, Chartularium Universititis Parisiensis (Paris, 1889-1 894)-and the Auctuarium Chart. Univ. Paris (Paris, 1894). 
proposition whatsoever, that two and two are four, for example, logic absolutely forbids every other science to arrive at any conclusion that would overthrow that judgment of mathematics. 'There, simply, is the whole reasoning of the scholastics. It is an application of a miversal law of solidarity that is true of all the sciences, whether rational or experimental. We see it in our own days applied to the manifold relations between physics, chemistry, astronomy, mechanies, and in general all the sciences that approach a common subject-matter (material object) from different points of view (formal objects).' The truth or otherwise of the hypothesis-the existence, namely, of a Divine Revelation-does not fall within the competence of the philosopher. But granted that hypothesis, the consequence of the conditional is beyond all debate: reason must aroid running counter to a dogma supposed to be certain, for truth cannot contradict truth. " Supposito quod huic scientix (that is to say, theology) non subjacet nisi verum - . supposito quod quxecumque vera sunt judicio at auctoritate hujus scientiæ, falsa nullo modo esse possunt judicio recte rationis. His inquam suppositis, cum ex eis manifestum sit quod tam auctoritas hujus scientix quam ratio . . . veritati innituntur, et verum vero contrarium esse non potest, absolute dicendum quod auctoritati hujus scriptura nullo modo ratio potest esse contraria, immo omnis ratio recta ei consonat $"{ }_{2}$

Such then is the special point of view from which the doctors of the Middle Ages proclaimed the primacy of theology. It is a point of view that the historian ought to understand and respect. Now, what is the nature and extent of this control to which scholastic philosophy submitted ? A certain scholastic

1 We see yet another application of the law in the condition for a scientific hypothesis, that the latter must not contradict any conclusion demonstrated as certain.

" Henry of Ghent, Summa Theologica, ro, 3, n. 4. 
formula has been much abused in this connection. Philosophia ancilla theologia would seem to deprive the former of all independence of action. Nor is it without interest to recall the fact that St. Peter Damian, who gave it currency in the eleventh century, belonged to the school of those exclusive theologians who thought little of philosophy (40). The formula is therefore suspect, and expresses only very imperfectly the conception of the scholastics.

Imagine a traveller left to himself in a vast forest which he wishes to explore; nothing to hinder him in his movements and searchings : he wanders about at will, up and down, left and right. But at certain points that are near precipices, some friendly stranger's hand has erected warning notices, that such and such a direction leads to some abyss or impassable ravine. The comparison does not come to us from the Middle Ages, but it conveys their thought: the control which theology exercises over rational research is rather of a negative and prohibitive kind. Theology does not at all interfere with the characteristic outlines and principles and method of philosophy, but in certain questions it warns the latter not to reach conclusions in contradiction with its own. We need hardly mention that this prohibitive attitude is conceivable only where both sciences meet on a common ground: an observation that will soon lead us to an important conclusion. Moreover, the theologian's prohibitive attitude does not necessarily give any positive direction to the philosopher's researches; seeing that Revelation contains dogmas that are mysteries, surpassing the power of reason, and that even those of its truths that are accessible to reason can assume a philosophical character only on condition of being demonstrated.'

1 The above theory on the subordination of philosophy to theology is very clearly set forth by Henry of Ghent, Summa Thcologica, art. 7 , De Theologia in comparatione ad alias scientias. 
39. Besides that dependence, of which we have just outlined the principles and indicated the limits, history also reveals another relation between scholastic philosophy and scholastic theology, an interchange of scientific services redounding to the profit of both sciences, a positice co-ordination of bothsomething quite different from the simple mixture of philosophical and theological matter's already referred to (22). Is regards philosophy, its very character of "scientia subalternata "implies a certain indirect limitation, by the " scientia subalternans," on certain delicate problems, such as, for example, the notions of person and nature. But what we have already said about the subordination of the two sciences finds its application here also; such limitation supposes that they meet on common ground. Now this borderland is more restricted than is commonly beliered: in quite a multitude of departments all co-ordination of the two branches of knowledge is precluded by the very nature of the matters dealt with (43). As regards theology, the question is: did it have recourse to philosophy for a rational justification of its dogmas, for an apologetic of Revelation: or, as it is usually put, did it make use of the dialectic method? - a question of great importance in the history of theology, one that also indirectly interests scholastic philosophy, and whose solution, moreover, will clear up a question already touched upon.

40. An autonomous science, medieval scholastic theology had its own autonomous constructive methods, just as philosophy had its own too. Those methods are proper to theology, to the content of the Christian Revelation. They have to do chiefly with the interpretation of the Scriptures and the Fathers . . . At the same time, however, the more important group of medieval theologians had recourse, in addition, to a subsidiary method, the 
dialectic method. In virtue of that method, theology seeks the aid of its sister science, philosophy, and gets from it those motives of credibility that constitute the preliminaries and lay the foundations of the sacred science itself. Furthermore, whenever it lays down a dogma it endeavours-not indeed to demonstrate it from reason, but-at least to show its rational character; and so the authority of the Scriptures is supplemented by a veritable apologetic. The introduction of this dialectic method gave rise to stirring controversies amongst the theologians, and will serve as a basis of division for the various parties whose origin and general significance are all that concern us here.

The argumentative theology that made use of dialectics, and thus built up "scholastic theology" proper, developed largely along two great lines, shown clearly to be divergent by the recent researches of Deniflé and Gietl. ${ }^{1}$ Those were the schools of Abelard and of St. Victor, respectively. Though both these schools alike laid reason largely under contribution, alongside the fundamental study of the Scriptures and the Fathers, yet they contributed differently to the final triumph of that method which was to achieve such brilliant results in the hands of the great theologians of the thirteenth century. While the school of Abelard exaggerated the importance of dialectics, and often applied them imprudently, forgetting that they play only a subsidiary role in theology, the school of St. Victor confined the method within the boundaries of perfect orthodoxy. The two schools, therefore, played quite different parts. " They did not need," as Fr. Portalié very well says, "to set up as a principle the introduction of philosophy into theology: that

1 Deniflé, Abaelard's Sentenzen und die Bearbeitung seiner Theologia, in the "Archiv fur Litteratur und Kirchengeschichte des Mittelalters," I885, vol. i.-Gietl, Die Sentenzen Roland's nachmals Papstes Alexander III. (Fribourg, I89I). 
had been already done by Anselm, and-a little reluctantly-by Lanfranc. Hugh of St. Victor, like Abelard, adopts the principle, and both display the same zeal in its application. It is entirely false that the school of St. Victor impeded the seientific development of the faith by an excess of mystical symbolism. . . But, on the one hand, it is certainly to the school of Abelard that we are chiefly indebted for the thres essential improvements of the new theology: the idea of condensing into a Summa worthy of the name a complete synthesis of theology, the introduction of a more exact dialecetical procedure, and the fusion of Patristic erudition with rational speculation. . . On the other hand, it is to the school of St. Vietor alone that the glory belongs of saving the credit of the new method when it wis serionsty imperilled by the doetrinal temerities of Abelard."

The thirteenth century profited by those experiments, and the two currents that issued from the school of St. Victor and from that of Abelard united in the great theological works of the princes of scholasticism. According to the teaching of St. Thomas Aquinas the autherity of the Scriptures supplies theology with it proper and cogent proofs, while the authority of philosophical reason is of a subsidiary and accessory kind."

It must be borne in mind that this Dialectic . Method to which theological reasoning has recourse, belongs to theology rather than to philosophy. That is because

${ }^{1}$ I'ortalié, Ecole thél.gique d'sbélard, in the Dictionary of Catholic Theology, published by Vacant (Paris, I 899 ), vol. i., pl). $5+$ and 55. For the rise of this theological method, see also Féret, La faculté de théologie a P'aris (Paris, I894), vol. i., pp. 18-22. Torreilles, Le mouvement the ulogique en France depuis ses origines jusqu'a nos jours (Paris, I 902$), \mathrm{pp} .8$ and fol.

- See the Prologue of the Commentary on the Sentences. art. 5. Fr. Gardeil has clearly expounded the nature of the relations lietween these two methods in a study on the Reform of Catholic Theology; The documentation of St. Thumas (Revuc thomiste, Nay-June, 1003), pp. Iog and fol. 
of its avowed object : to make the resources of human reason subserve the direct apologetic of a dogma fixed beforehand. So much was admitted by the philosophers themselves. We find, in 1272, a manifesto issued by the vast majority of the masters in arts against a turbulent faction of Averroïsts, formally forbidding both masters and bachelors of the Faculty to "determine" or even "dispute" matters theological. That would be, says the document, to outstep the boundaries prescribed for philosophers. But, as Aristotle says, he who is not a geometrician cannot, without grave disadvantages. discuss geometry. Such texts must be peculiarly embarrassing to those who will insist on denying the existence of a philosophy distinct from theology in the Middle Ages.

On the other hand-there is hardly need to mention it-those same theologians who advocated the application of dialectics to matters of revelation, had been, and continued to be sincere philosophers as and whenever occasion demanded; discussing, in that capacity, theories offered in explanation of the natural order of things, as, for example, the notions of movement and of efficient cause, and the problem of the origin of ideas : questions entirely unconnected with scriptural and patristic studies. While that is true, however, there was also another section of theologians who did not share those views, either on the rights of the dialectic method in theology, or even on the autonomous value of dialectics and philosophy in themselves. There was always a party of reactionaries who took fright at the spectacle of the heresies to which the abuse of dialectics had led, and who would

I " Statuimus et ordinavimus quod nullus magister.vel bachellarius nostræ facultatis aliquam questionem pure theologicam, utpote de Trinitate et Incarnatione sicque de consimilibus omnibus, determinare seu etiam disputare presumat, tanquam sibi determinatos limites transgrediens, cum sicut dicit philosophus non geometram cum geometra sit penitus inconveniens disputare." Deniflé and Chatelain, Chartularium Universitatis Parisiensis, vol. i., p. 499. 
prevent the repetition of such heresies by condernning the method itself whence they had sprung. Of their number were St. Bernard and Stephen of Tournai. What is more: certain rigorist and exclusive theologians were in the habit of declaring war against all profane seience, and their influence. too', had to be counted with. Amold of Bonneval, Hugh of Amiens, Peter of Rheims or Petrer the Chanter, not to mention the more exalted mystics like Walter of St. Victor, would recognise but one form alone of knowledge, to wit, the revealed word: and their lamentations on the subjection of theology to dialeeties found an echo in the full scholastic turmoil of the thirteenth century. ${ }^{1}$ Others again give evidenees of a tendency that was more moderate. Peter Lombard, for example, takes up a sort of hesitating attitude. In the Book of Sentences pliblosophy is for him a mere instrument, of which moreover he makes but little use. He does not regurd it as an autonomous science interpretative of Reality. ${ }^{2}$ I century before him, St. Peter Damian had depreciated the rôle of philosophy in a similar way; in his view, it ought "velut ancilla dominse quodam famulatus obsequio subvenire." 3

41. To sum up and conclude :-

(a) The most remarkable personalities of the Western Middle Ages were both philosophers and theologians, ${ }^{4}$ and this double role is in a certain way alternately manifested in their works $(5,22)$. As

I Mandonnet, Siger de Brabant, etc., pp. 46 and 70. There were, therefore, theologians who refused to be philosophers; there were not, to our knowledge, any philosophers who did not grapple with some or other question of theology.

- Cf. J. N. Espenberger, Die Philosothie des Petrus Lombardus und ihre Stellung in zwölften Jahrhundert (Beiträge zur Ge:sch. der Philos. iii., 5, Münster, I90I).

${ }^{3}$ Opusc. 36, Quoted by Espenberger, p. 36, n. 2.

${ }^{4}$ Deutsch, Petrus Abelard (Leipzig, I883), p. 427, hrings out very clearly this distinction between the philosophy of Abelard and his theology. Fr. Portalie, in the articles referred to, is evidently of the same way of thinking. 
philosophers their pre-occupation was to find an explanation of the order of Nature by the sole light of reason. For that they had recourse to the intellectual legacies of Greek antiquity and of the Patristic epoch (Section 8). They were all the time mindful of Catholic Theology, and professed a submission, not "formal," but " material," to its dogmas. As dogmatic theologians, their purpose was to give a systematic exposition of Catholic belief; and in doing that they used the argument from authority as the principal proof. Moreover, by employing the dialectic method and extolling its utility, as most of them did, they claimed for philosophy the place of an auxiliary science, and thus admitted it to a unity of a higher order.

(b) Philosophy, therefore, figures in medieval speculation on a two-fold title: It has, firstly, an autonomous value; and this is mainly the point of view from which it occupies the attention of the historian of philosophy. Then, secondly, it inspires the dialectic method, and, accordingly it forms also the object of an important chapter of the history of theology.

Now, apparently, the majority of historians overlook this autonomous value of scholasticism and see in it nothing more than an apology for dogma. ${ }^{1}$ They forget that the Middle Ages expected something further from philosophy, and built up a complete synthesis of conceptions about God, Nature, and Man, that is to say, a philosophy proper, distinct

' Such, for example, is the view of Fr. Tyrrell : "By Scholasticism we understand the application of Aristotle to Theology, or the expression of the facts and realities of Revelation in the mind-language of the peripatetics." Still the author does not confound, as so many others do, scholasticism (meaning: scholastic theology) with the co-existing philosophy (which we call scholastic philosophy). For he adds: "It was the error of the scholastics to put too full a reliance on the secular philosophy, history, physics and criticisms of their own day." Tyrrell, The use of scholasticism, in The Faith of the millions (London, I902), pp. 224 and 225. 
from the theological monument. That forgetfulness we believe to be the cause of the widespread confusion of those two sciences, and of the consequent depreciation of scholastic philosophy.'

Scholasticism is not a mixed science, half-theological, half-philosophical. There is no such thing as a mixed science, for every science derives its specific nature and character from its formal object. and the concept of mixed formal object implies a contradiction. When scholasticism simply is spoken of,

We must, therefore, distinguish: (a) theology and its methods of authority; (b) the dialectic method in theology; (c) philosophy as an antonomous science. M. Delacroix shares, we believe, in this view: "M. De Wulf," he writes, "l,lames us for neglecting the distinction between scholastic philosopley and theology; we treely admit that the medieval philosopher distinguish these two domains (a and c); but, for them, the first-or, if you will, the last-problem of all philosophy, is that of the relations of Reason and Faith, of philosophy and theology, and it is on that point their philosophy and theology unite." La philosophic médivale latine insqu'an XI I'e. siele (Revue de synthese historique, August, I002), 1). 102, n. I.

On the other hand, M. Picavet wrongly" accuses us of "reducing medieval philosophy to an orthodoxy" under the name of scholasticism (howe philosophique, I902, 1). I84). Analysing our Histery of Medicial Philosofhy, he writes: "For M. De Wulf, therefore, scholasticism is the agreement of the teachings of the Catholic religion with the results of philosophical investigation. . . . So, he really rednces medieval philosophy to an orthodoxy which he calls scholasticism." (Ibid., T. I 84). We are surprised at such a judgment. M. Picavet has overlooked what appears to us all-important in scholasticism: the evolution of its doctrinal content. And he reproaches us for the very fault of which we accuse himself : the fault of seeing in scholastic philosophy only its relations with theology. In reality, according to our view, it is something altogether different from an orthodoxy or an apologetic. If we give Thomism the place of honour, it is not because "philosoplical Thomism in league with theological Thomism is the philosophy that excels all others and must be the standard for judging them" (p. 184), but simply because it is in itself the most complete expression of the scholastic synthesis. Far from us the thought of depreciating the value of other similar syntheses. Finally the criterium of the distinction between scholasticism and anti-scholasticism is by no means Catholicism, as M. Picavet asserts ("from this scholasticism, from this orthodox and Catholic plitosophy, M. I. W. distinguishes the doctrines, etc.," p. 184)-but the antagonism of the philosophical systems themselves; and if it is evident to him that such a division is valueless except for Catholics (p. 185), we believe that it has nothing whatsoever to do with the personal religion of the historian, who must always distinguish-no matter what religion he belongs to-between the philosophical conception of J. Scotus Eriugena and that of St. Thomas of Aquin. 
it must mean either theology or philosophy, not both together. ${ }^{1}$

42. The general relations between scholastic philosophy and dogmatic theology, hold good also, mutatis mutandis, between that same philosophy and mystic theology. This latter is a department in the supernatural order, and has therefore nothing in common with philosophical research. To realize this, one has only to see that the "mystic ways," the raptures and ecstasies which encompass the union of the soul with God, and which are described in such glowing terms by a Hugh of St. Victor or a Bonaventure, are essentially different from the analogical and negative knowledge of God, arrived at by philosophical speculations $(70,71)$. They are the steps of a steeper ladder which it is not given to man to climb without new stores of energy imparted by grace from on high. If, then, the great leaders of medieval philosophy had their hours of mystic elevation, we must not infer any real confusion of scholasticism and mysticism, but simply a co-existence of mystic knowledge and scholastic thought in the minds of certain doctors. They are at the same time mystics and philosophers, because they are theologians as well as philosophers. If St. Thomas wrote a treatise De Ente et Essentia and also hymns to the Blessed Sacrament, it is because there were really two men in him, as it were, obeying two distinct inspirations. In the famous fresco of Taddeo Gaddi at Florence, symbolizing the cardinal virtues, the old and new Testaments, the seven liberal arts, civil and canon law, theology at once speculative and mystic, the artist does not mean to portray the confusion of all the intellectual studies of the Middle Ages in one

I "Scholasticism, writes M. Elie Blanc, has this peculiar to it, that it harmonizes philosophy and theology . . . it is, if you will, and it must necessarily be, a mixed science, theology if it proceeds from faith, philosophy if it proceeds from reason." In the Universite Catholique, 1901 (p. I I4). 
single science-scholasticism. Pather, he wants to express the harmonious convergence brought about by modieval culture between distinct sciences, under the queenly primacy of theology. The fresco is a fitting commentary on the Bible text transcribed by the painter on the book that lies wide open on the knees of the saint: "Propter hoc optavi et datus est sensus. et invocavi et renit in me spiritus sapientia et proposui illam regibus et sedibus." 1

43. In the light of these historical facts it will be easier to decide whether the subordination of philosophy to theology (38) or the primacy of the latter, can yield a satisfactory definition of scholastic philosophy. We think it cannot-whether we make the scholasticity of a philosophy a generic notion. to be differentiated by this or that regulating dogma, or whether we apply the term only to philosophies in harmony with the religions of the Middle Iges. and notably with the Catholic religion. And here are our reasons :-

Firstly-Although the reality of that subordination of philosophy to medieval theology is incontestable, and although it characterizes scholasticism far more than the mothod of teaching in use at that epoch (Section 3), still the present definition no less than the former is open to the same general objection that it does not point out what constitutes scholastic philosophy as such, that is to say, in its doctrinal content. It embraces only attributes extrinsic to the thing to be defined ( 7 ) : and of necessity these attributes are secondary. Hence:

Secondly-Whatever be the cause, the extent and the nature of the subordination of scholasticism to theology, is it not evident that this philosophy will have a meaning in itself-abstracting altogether from the dogma on which it is the commentary-in the measure in which it will offer a rational explanation

'Sap., $7,7$. 
of things? From this point of view, the Upanishads contain a pantheist or subjectivist philosophy; the scholasticism of the thirteenth century an individualist and objectivist philosophy. T'he former might be compared with the systems of Kant and Fichte; the latter with that of Aristotle.

Similarly, if you speak of an Arabian scholasticism with M. Carra de Vaux, or of a Jewish scholasticism with M. Zeller, must you not also admit that such theories as the procession of the spheres, the unity of the intellect, the dualism of God and the r.oyos, give to Avicenna's synthesis or to Philo's syncretism a meaning profoundly different from that contained in the synthesis of Thomas Aquinas? To understand the philosophical personality of those three leading representatives of three great races, it will not suffice to say that they are scholastics; we must go farther and look at their philosophy in itself. And again, Reuchlin also has sought to reconcile philosophy with the Cabal, and Melanchton with the reformed dogma; but independently of their religious leanings, the two systems have also their own proper individualities, because they offer each a rational explanation of the universal order, capable of being appreciated as such. ${ }^{1}$ We see, then, that even in theories expressly related to dogma, there is room, and there must be room, for other test-elements besides their dependence on dogma.

Thirdly-This will become all the more evident when we consider that medieval scholasticism is composed of quite a crowd of doctrines having no

1 There is a Protestant scholasticism, writes M. Blanc (Université Catholique, Sept., 1902, p. I44), i propos of an article we published in the Revue Philosophique (June, 1902). We do not deny that the Protestants have a philosophy in harmony with the reformed dogma. But that is not the question. Our contention is that that philosophy has its own signification as a philosophy, irrespective of its relation to Protestant dogma. To deny that would be to deny its claim to be called a philosophy at all. M. Blanc has not, we think, sufficiently appreciated the point at issue. 
direct connection with Catholicism. And this is what we should expect. To be in the condition of servant implies being under the master's roof, or in the same profession, in the same administration, or at the very least, being occupied with the master's business. But scholastic philosophy is occupied with a vast number of problems that are no concern of Catholic dogma. To deny this would be to confound philosophy with apologeties, which have no other object and no other raison d'être than the justification of dogma : it would be to lie against history and convict one's self of culpable narrowmindedness in the study of the great medieval systems.

Nothing, in fact, in the written or traditional sources of dogma obliged the philosophers of the thirteenth century to explain the enigma of the constitution and changes of material nature by primal matter and substantial form. So true is this that Aristotle, who initiated that doctrine, took no trouble to harmonize his cosmology either with Catholicism -and for a good reason-or with any other religion whatever, and that several philosophers of the early medieval period adhered to the atomic theory notwithstanding their Catholicism. And will it be said that the theory of matter and form, so fundamental in scholasticism, ought not to be taken into account in forming an estimate of the scholastic conception of the cosmos: or that even in Aristotle this doctrinc. has no intrinsic philosophical significance ; or perhaps that this Aristotelian doctrine loses its value in scholasticism by the mere fict of its being transferred to the Middle Ages and co-ordinated in a common synthesis with theories controlled by dogma? Moreover what is true of matter and form is true of the theory of the potentia active et passiva, of the principle of individuation, of the distinction between essence and existence, of the theory of the rationes seminales, of the unity or plurality of the substantial 
principle in things; of the whole logic, psychology and ideogeny of scholasticism, notably of the formation and function of the species intentionales; of the subordination of will to intellect, of the manner of exercising volitional activity, etc. ${ }^{1}$ The territory that is common to scholastic philosophy and theology is much narrower than these sciences themselves: and outside that common territory the subordination of one of them to the other would have no meaning (38). Hence that subordination is incapable of defining scholasticism as such.

Finally, what are we to think of the more abstract conception that would make scholastic philosophy a philosophy subordinated to any dogma whatever, and which would see in Catholic scholasticism a variety analogous to Indian, Arabian, Protestant and other scholasticisms? Here again the same difficulties recur in a more general way. The distinctive element of each variety is a religious and dogmatic element, an extraphilosophical element, therefore; and so we continue to characterize a philosophy by that which is not philosophical (see first reason)-an unscientific procedure. Furthermore, whether the ruling dogma be Brahminism or Mahommedanism, or Catholicism or Protestantism, we forget that the philosophical theories subordinated to such dogmas will nevertheless possess a meaning of their own, looked at from a properly philosophical or rational point of view (see second reason). Finally, where there is question of a real synthesis, it will include a multitude of solutions beyond the control of dogma, the latter having nothing to do with the questions that called forth those solutions (see third reason).

I M. Blanc disputes those facts, which nevertheless appear to be well founded, especially when we consider that many of those questions were taken from Aristotle (in a note in the Université Catholique, 1902, p. I 45, n. I). 
Fourth reason-Then, in the last place, if we were to define scholasticism as a philosophy in harmony with dogma, we should arrive at this unexpected consequence, that we might and should distinguish in one and the same scholasticism-the Catholic, for example-manifold and contradictory types. Would anyone say that the Augustinian ideology may be reduced to the Thomistic? And yet is St. Augustine less a Catholic in his theology, or otherwise a Catholic than St. Thomas: ${ }^{1}$

Even the pantheists, thanks to their allegorical or symbolic method of interpreting the Scriptures, even the Averroists, thanks to their doctrine of the two truths, safeguard or imagine they safeguard their orthodoxy : nay. many of them even boast of having the true spirit of the Gospels." On the threshold of the Renaissance. Nicholas of Cusa, a Cardinal of the Chureh of Rome, could discover ingenious means of reconciling his dangerous doctrine of the coincidentia oppositorum with his Catholicism. Descartes, Gassendi and Malebranche professed the same faith as Thomas Aquinas, and accommodated their philosophy to their belief. The accommodation, no doubt, is not so happy, but that is due to the structural weakness of their philosophy itself, and does not affect our argument.

We say, therefore, that to call the philosophies of Augustine, Thomas, Descartes and Malebranche, scholastic, is to close one's eyes to history; for history

${ }^{1}$ It is on the solution of the ideological problem that M. Blanc makes all philosophy depend (op. cit., p. I39).

2 In the Middle Ages nc one cpposed logma, but each one explained it for himself. See, for example, the efforts of J. Scotus Eriugena to reconcile his pantheism with the Catholic faith. M. Delacroix has found evidences of the same spirit in the mystic pantheists, of whom he has made such a brilliant study (Essai sur le mysticisme spéculatif en Allemagne au IIVe siècle, Paris, 1900). That is why we think, in opposition to him, that a classification of medieval systems into scholastic and anti-scholastic, on the basis of their submission to dogma or revolt against its yoke, is devoid of utility and at variance with the facts. See above, p. 52 . 
represents those systems as occupying opposite positions and engaged in endless conflict. You might as well identify the different political groups of a Parliament on the plea that they are all alike citizens of the same country. And moreover, if such an identification of philosophies were possible, it would be an obstacle to any analysis of the differentiating qualities of those scholasticisms themselves: unless indeed an appeal be made to elements foreign to dogma, and specifically Augustinian, or Thomist, or Cartesian, etc.-a procedure which leads to another definition, to be discussed later on (Section 11).

\section{Section 8.- Scholastic Philosophy and ANcient PHILOSOPHY.}

44. A hoary prejudice, sown by the Renaissance (2), sees in scholasticism a mere counterfeit of the ancient Greek, and especially of the peripatetic,

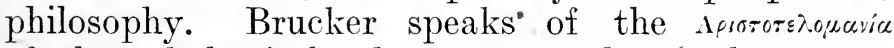
of the scholastics ${ }^{1}$; he accuses them-always on the strength of Vivès - of having failed to understand Aristotle, and makes fun of their "supreme reason" for admitting or rejecting a thesis: "videlicet Aristoteles dixerat. ${ }^{3}$ Fr. Bulliot, of the Catholic Institute of Paris, seems to subscribe to those outof-date views, when he considers scholasticism as a mere phase of Aristotelianism. ${ }^{4}$

45. It cannot be denied that the scholastic philosophy is most closely allied to the peripatetic, and that "the logical and metaphysical organism which is the creation of the founder of the Lyceum, also

${ }^{1}$ Op. cit., vol. ii., p. 885 .

In Section XII : Aristoteles a scholasticis non intellectus, ibid., p. 886.

"p. 885 .

- See Report of the International Philosophical Congress (Paris, 1900), published by the Revue de métaphysique et de morale, 1900, p. 601 . 
characterizes scholastic philosophy, though only in an accessory way." " None of the ancients enjoyed such medieval renown as Aristotle. Eren before the West had heard of his three famous treatises on Physics, on Metaphysics and on the Soul, John of Salisbury could write:

Si quis Aristotelem primum non censet habendum,
Non reddit meritis præmia digna suis,

and with the exception of the exclusive theologians (41) who accused him of the worst errors of heterodoxy, these eulogiums were ratified by all. We may add too that a number of the great doctors of the thirteenth century-Albert the Great, Thomas Aquinas, Henry of Ghent, Godfrey of Fontaines, Duns Scotus-possessed such a knowledge of Aristotle as many of our moderns might envy.

But there is a long road between the Aristotelianism of the scholastics and the plagiarism of which they are accused. As early as 1840 , Ritter regarded this allegation of the historians as a " deep-rooted prejudice "which "he believed he had fully extirpated." Willmann refers and subscribes emphatically to this testimony." Moreover, is it possible that an entire epoch would have abdicated, for one man however great, the right of reflection and investigation? No thinking man could follow in the footsteps of another with such servility as not to leave after him some mark or other of his own personality.

Perhaps it is because the scholastics themselves were so obstinate in clinging to Aristotle that they are accused of following the Stagyrite like so many sheep? But let us not be too credulous when we hear the medieval doctors boast of " commentating" Aristotle. For those commentators cannot avoid

1 Gonzalez, op. cit., v. ii., p. I27.

- H. Ritter, Geschichte der Philosophic, Bal. vii., p. 9.-Willmann, op. cit., Bd. ii., p. 339 . 
interpreting Aristotle in their own sense, nor do they make any scruple of doing so (21). The Aristotle of St. Thomas, no less than the Aristotle of Andronicus of Rhodes, of Alexander of Aphrodisias, of Themistius, of Simplicius, of Averroes, is an Aristotle clothed after the taste of his commentator. It is quite certain that the doctrines of the Stagyrite were subjected to critical verification. "To set up Aristotle as infallible would be to make a divinity of him," said Albert the Great. "But as he is only a man, he is, like the rest of us, subject to error." Hence it is that scholasticism freely rejects certain of Aristotle's doctrines, such as the divinity of the stars, the absolute quietism of the Pure Act, the necessary eternity of the world. It removes the doubts that clouded his conception of the personality and life of God. It corrects and completes such theories of his as that of matter and form. Several doctrines regarding theodicy, ideology, efficient causes, personal immortality and beatitude, are, from many points of view, veritable victories of medieval genius over Aristotelianism. A detailed analysis, beyond the scope of the present work, would bring to light, in almost every question treated by the scholastics, divergences separating them from Aristotle. ${ }^{2}$ In any case, whatever Aristotelian theories may have been borrowed by scholasticism, and whether it appropriated them unchanged, or modified or completed them, it always submitted them to a process of original criticism that redounded to its own advantage as a new and distinct method of philosophizing.

46. Then, too, scholasticism was influenced by other philosophies besides the peripatetic. Pythagorism, Atomism, Platonism, Epicurianism, Stoicism,

1 "Qui credit Aristotelem fuisse Deum, ille debit credere quod nunquam erravit. Si autem credit ipsum esse hominem, tunc procul dubio errare potuit sicut et nos." Phys., lib. viii., tract. i., cap. xiv.

${ }^{2}$ See some efforts in this direction in Talamo, L'Aristotélisme de la scolastique (Paris, 1876). 
Neo-Platonism, the new ideas of the Patristic philosophy and notably Augustinism, occupy a place which has been for ages unacknowledged in Western medieval controversies. Plato and St. Augustine excited a degree of admiration which rivalled the enthusiastic homage paid to Aristotle. So much so that in the thirteenth century we find, in opposition to the peripateticism of the Thomist school, an important group of scholasties inspired chiefly by Augustinian sympathies (31). If a fanatical "ipsedixitism" was the repreach of the decadence, the philosophers of the great scholastic century are free from it. Locus ab auctoritate que jundatur super ratione humana est infirmissimus. ${ }^{1}$ What guided the scholasties in borrowing from the past was by no means their blind cult of some great figure of history, but their thirst after truth for its own sake (2i). As one of themselves is represented to have said. they climbed on the shoulders of the giants of antiquity in order to discem a still erester stretch of the intellectual horizon." Scholasticism asks light of all previous philosophies, but it is the slave of none of them. In its perfect form it is the issue of a specific eclecticism. Its borrowed materials are arranged in a new setting and incorporated into an independent and original structure.

\section{Section 9.-SCholastic Philosophy AND THE MEDIEVAL SCIENCES.}

47. Scholastic philosophy was made to harmonize not only with Catholic dogma, but also with the rational and natural sciences, ${ }^{3}$ in conformity with

1 St. Thomas Aquinas. Summa Theol., I a, q. i., art. 8, ad 2.

2 "Nos esse quasi nannos gigantium humeris insidentes, ut possimus plura iis et remotiora videre." Quoted by Willmann, Didaktik (Brunswick, 1903), v. i., p. 272.

${ }^{3}$ See, for example, definition quoted on p. 44 . 
the all-pervading spirit of systematization that marks the intellectual work of the Middle Ages. To understand these relations between philosophy and the sciences, we must take notice of the then existing general classification of human knowledge. On this question, as on many others, we can say that notwithstanding numerous divergences the general attitude of scholasticism has remained unchanged. The thirteenth century consciously and explicitly formulated a system whose fragmentary outlines were all that existed in the early Middle Ages. 'We may accordingly recognise two principal periods in the history of the classification of the sciences. ${ }^{1}$

From the time of Alcuin the trivium and quadrivium furnished the materials for all scientific teaching (16). It is well known that the arts of the quadrivium were never able to rival in popularity the trilogy of Grammar, Rhetoric and Dialectic, and that the latter of these three was not long about eclipsing the other two branches of its group." But dialectic is only the vestibule of philosophy, or at the very most one of its divisions and not the principal one. How then did universal philosophy find a place within the pedagogic framework of the liberal arts? The problems of metaphysics, theodicy, psychology and ethics, almost entirely unknown in the eighth century, and raised by degrees afterwards, form a very considerable body of doctrine. Was this a development, an offshoot from dialectic, so that all philosophy should be found in the trivium; or are all the liberal arts no more than a preparation for philosophy, which accordingly, from the beginning of the eleventh century (to fix an approximate date), would assert itself between the quadrivium and trivium below, and theology above? The former

\footnotetext{
1 See an interesting work by J. Mariétan, Problème de la classification des sciences d'Aristote à saint Thomas (Paris, I9OI).

2 See Willmann, Didaktik (Brunswick, 1903), v. i., pp. 266 and fol.
} 
of these explanations, commonly admitted and even generalized," will be found to suit well enough the beginnings of Western pedagogy, and the unsettled notions accepted by the earlier generations of teachers, contemporaries of Alcuin." But the second interpretation is more in keeping with the genius of scholasticism. It points to a tendency that took shape with Scotus Eriugena (ninth century), asserted itself in Abelard (eleventh century), and finally triumphed in the twelfth rentury in these views of Hugh of St. Victor: "Sunt enim (septem artes liberales) quasi optima quiedam instrumenta et rudimenta quibus via paratur animo ad plenam philosophica veritatis notitiam." 3 Then finally it falls in with the systematization of sciences adopted in the thirteenth century.

48. This systematization took its final shape as soon as the introduction of the greater works of Aristotle gave a new impetus to scholastic studies. The liberal arts are not removed from the programme, but their role as preparatory studies is clearly established, ${ }^{4}$ and much of their subject-matter reappears in the wider classification now adopted. This latter is peripatetic in spirit and origin; it turns on the Aristotelian conception of sapientia, or of scientia in the fullest and deepest sense of the word. Its general outline is as follows: The special sciences are devoted to a detailed study of nature; each of them deals with some single category of the objects

${ }^{1}$ See, for example, Ferrère, La division des sept arts libéraux (A nnales de Philosophie chretionne, 1900, p. 282).

2 This is, we believe, the view of M. Marictan. Sce op. cit., pp. 86 and 805 .

"Evud. didasc. 1. 3 (Migne's edit., v. I76), col. 768. Quoted by Mariétan, op. cit., p. $84 \mathrm{I}$.

${ }^{*}$ In proof of which we may quote this text of St. Thomas, written a propos of an expression of the same view by Hugh of St. Victor: " his (that is, the liberal arts) primum erudiebantur qui discere volebant philosophiam; et ideo in trivium et quadrivium distinguuntur eo quod his quasi quibusdam viis vivax animus ad secreta philosophix introeat." In lib. Boetii de Trinitatc, q. v. a. I (ed. Vivès, p. 528 , v. 28). 
that come under our observation, and approaches them from some one special point of view which constitutes the formal object of that science, gives it its specific character, and determines its principles and method. An example given above to illustrate the difference between astronomy and what we now call physics, will make this perfectly clear (Sect. 5).

That the full course of philosophy in the thirteenth century included scientific matters, will be evident to anyone who consults the regulation issued by the Faculty of Arts at Paris, on the 19th of March, 1255, de libris qui legendi essent. These comprise commentaries on the various scientific treatises of Aristotle, especially on the first book on meteors, on the treatises on the heavens and on the world, on generation, on the senses and sensation, on sleep and waking, on memory, on plants and on animals. There the magistri had certainly sufficient data for instructing the "artists" on astronomy, botany, physiology and zoology-not to mention the fact that Aristotle's Physics, the recognised classic text, opened up numerous questions on physics and chemistry in the modern acceptation of these terms.

But this analytic glance at the various departments of the world of sense does not embrace all that is knowable in it, and the mind is by no means satisfied with such a disconnected and encyclopedic view of things. Science par excellence - that is, philosophybeing, in the Aristotelian and scholastic conception of the matter, a knowledge of the very inner nature of things, demands a regressive movement of thought. "It has for its object, not the discovery of any new objects of knowledge by way of analysis whether direct or indirect, but the synthetic explanation of the results already reached by analysis." 1 When the study of nature in detail is carried far enough, " a more mature reflection on the results may suggest

${ }^{1}$ Mercier, Ontologie (Louvain, 1903), p. 18. 
investigations of a new order: May not the beings and groups of beings observed separately, be perhaps examined together to see what they have in common? And if, by an effort of abstraction, a common intelligible aspect be found in them. may we not be able, by means of that common intelligible aspect, that is to say. symethetically. to understand more fully the results obtained br our previous work of analysis? That, precisely, is the object of scienee properly so called. of what Aristote defines as the knowledge of things by their rauses or principles-of what we nowadays profer to all philosoluhy.

Philosophy thus becomes the science par escellence. because it seoks as sonthetic and deduetive explanation of things. In a war. it knows all things-inasmuch as its way of knowing. its reason for knowing, includes and rules over all things. Supientide sot scientia qua

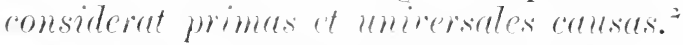

49. Now the seholasties, following up the Aristotelian conception, brought out the nature of this synthetic process: as abstraction is the law of the human mind (Soction !6). they came to discern in the world of knowable things. three common or allcmbracing intelligible aspects or objects, fruits of a threcofold precess of abstraction. each oftort of which surpassed the preceding one by the wideness and depth of the reality it seized. The division of speculative philosophy into physics. mathematies and metaphysics. is based on these three steps in the synthetic or regressive eonsideration of the totality of things. It is fomd on the first page of Avicenna's metaphysies as well as in practically all the works of St. Thomas. ${ }^{3}$ No other scientific classification "an ever rival it in endurance, seeing that it has reigned supremo from Iristotle to Descartes, and that

'Hid., pl, ii.-iii.

"Thomas Aquinas, In Mctaph., I, 2.

"Aricenna, Metaphysica, lenice elition, I.95, fol. I, R.A-St. Thomas Aquinas, In J.ib. Fotii de Trinitute; (1. 5. a. I, and elsewhere. 
it can still compare favourably with even the most popular of our modern classifications.

Physics, in the older and etymological meaning of the word pirs, studies the sense world as subject to change or movement. Botany and Zoology, for example, pass over the characteristics peculiar to this or that individual plant or animal-for science is of the universal only-but the realities which these two sciences fix upon in the plant or in the animal, or in the various classes of plants and animals, are of necessity restricted to some group or groups of living things. Physics, on the contrary, lays hold of a reality which is not confined to any special class of bodies, but one which is common to all bodies as such : corporeal change and the inner nature of corporeal things as subject to that universal law of evolution. or change.

But throughout its ever-varying forms of change, there is one persisting fundamental property which every body retains-its quantity. To follow up the study of that one property, separating, in thought and by thought, the quantity itself from the body which it quantifies, and looking only at the quantity itself as such, quantity as intelligible, therein lies the whole work of Mathematics.

Metaphysics or Transphysics, sometimes also called Theology, rises one degree higher still in abstraction and consequently also in generalization. It passes over the reality of change by which bodies reveal themselves to the physical scientist, and reaches beyond the fundamental attribute of quantity, that inseparable property of bodies,-in order to grasp the substance itself of them, the very being of things. And even if the things which the metaphysician studies are of a sensible, material nature, he studies them apart from their materiality; so that the science of being came to be called without distinction the science of the immaterial. 
Physics, Mathematics, Metaphysics: such is the trilogy of speculative philosophy, of the synthetic knowledge of the universal order of things. These ideas will be further developed when we come to pass in review the fundamental doctrines of each of those branches (Sections 12-17).

To complete this tableau of the classification of philosophy, we must add to the group of speculative sciences in which disinterested knowledge is its own end, a group of practical sciences in which knowledge is subordinated to our conduct or to our activity. "Theoreticus sive speculativus intellectus in hoc proprie ab operativo sive practico distinguitur. quod speculativus habet pro fine veritatem quam considerat, practicus autem veritatem consideratam ordinat in operationem tamquam in finem." Logic which regulates the acts of the understanding so as to secure by their normal functioning the acquisition of truth, and Moral which directs our free acts towards our last end, are the two practical sciences that were mainly cultivated. The preliminaries of logic are grammar and rhetoric, and their official teaching was organized by the Paris Faculty of Arts on the lines of the ancient trivium. On the other hand, moral was accompanied by historical studies, chiefly by Bible History and a part of that wide department nowadays covered br the name of Social Sciences. ${ }^{2}$

The subjoined scheme indicates the relations to philosophy, of the sciences that received most attention from the philosophers of the thirteenth century:-

\footnotetext{
Philosophy.
A.-Theoretical $\begin{aligned} & \text { I. Physics. } \\ & \text { Sciences }\end{aligned} \quad\left\{\begin{array}{l}\text { 2. Mathenatics. } \\ \text { 3. Metaphysics. }\end{array}\right.$
B.-Practical $\{$ 4. Logic. Sciences $\{$ 5. Moral.

Special Sciences connected. Astronomy, Botany, Zoology, Chemistry, Physics (in the molern sense).

Grammar, Rhetoric.

Bible History, Social and Political Sciences.

${ }^{1}$ Thomas Aquinas, In Lib. Boctii de Trinitate, q. v. a. I (Vives edition, vol 28 , pp. 526 and 527.)

2 Willmann, Gesch.d. Idealismus, vol. ii., p. 4 is.
} 
50. This hierarchical conception of the various branches of human knowledge is the source of the relations established in the Middle Ages between philosophy and the special sciences. In the first place, the special sciences were not marked off from one another nor separated from philosophy as they are to-day. They were in process of formation. They rested on rudimentary observations, and the distinction between ordinary and scientific knowledge was unknown. They had their raison d'être as a preparation for philosophy rather than as independent branches of study. ${ }^{1}$ In the second place it was inevitable that scholastic philosophy should assume a scientific character. How could it be otherwise, seeing that the detailed analytical data furnished by the special sciences that deal with physical nature are the indispensable materials for those synthetic views and large conceptions that form the proper object of philosophy? In the sciences no less than in philosophy one and the same fundamental law governs the ideological process : the closest possible knowledge of the material world is the proper, adequate and natural object of the human intellect (Section 16). Therefore ought not every interpretation of the world, including the synthetic explanation sought by physics, mathematics, metaphysics even, rest on observation at every moment, and at every single step by which its progress advances? Without such abiding contact with the living facts of the experimental sciences, what could the whole structure hope to be but a mere chimera devoid of all reality ? In the third place, medieval scholars recognised no distinction of nature between the special sciences and philosophy, since both are built up by one and the same intellectual process of abstraction. There

${ }^{1}$ Hence the current notion that in the Middle Ages the sciences formed an integral part of philosophy. "Die Naturwissenschaft ist den Scholastikern als Physik ein Teil der Philosophie." Willmann, op. cit., vol. ii., p. 4I6.-Cf. Hogan, op. cit., p. 48. 
is only a difference of degree. resulting from the degree of abstraction to which the world is submitfed in each: while the particular science selects for itself ontological aspects spereial to one group of things. the synthetic science of philosophy embraces profounder asperets that are (oommon to all material things.

51. This principle of the eomserencen of philosophy and the sedences. as understond in the llidelle Ages. gives mity and solidarity to the varions departments of human knowledere It has many axcellent reasons to recommend it. The same. however. cannot be said of all the epplicetions of the principle in the Midelle Aeses. Mre shall not be in a position to determine exaletly hew far those applieations were warranted or unwaranted until we have tabulated from special momoeraphe the numeroms seientific theories of that time. This detailed study. though seareely better than heoun. hats abraty shown that aven in this dieretion the thirterenth century made considere able alvanees. When we shall have separated the elements of observation and experiment on the one hand from the philosophical theories based upon them on the other. we shall he able to assign their true value to each.

The scientifie observations made in the Middle Ages vary much in value. Some are correct though superficial: others are prejudiced, is priori, jllconducted and trivial. When the scholastics saw that the change of wine to vinegar, or of food to flesh and blood. Was a substantial change, they started

'Works have been pullished on the sciences of the Mlidlle Ages.

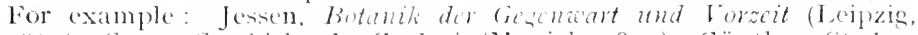
Is64)-Carus, Geschichte der Zoologic (Munich, I8;2)-Gïnther. Studen zur Geschichte der mathem. und phl's. Goographie-Terthelot, I.cs origines de l'alchimie (Paris, 1885)-Introduction al l'tude de la chimie

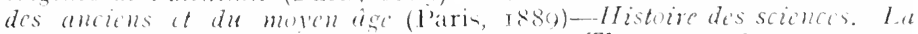
chimic an moln ig (Paris, Is93); cte. There are also numerous monographs, chietly on Albert the Great and lioger Bacon. On the former, soes also E. Nichail, (ieschichte des deutschen lobles (Fribourg,

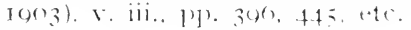


from data that were no doubt superficial-seeing that they were ignorant of the chemical constitution of bodies-but nevertheless from facts faithfully observed. On the other hand, when they relied on the faith of antiquity to infer from the apparent immutability of the stars that the matter of the heavenly bodies can be neither generated nor corrupted, they were accepting a fanciful datum on the strength of its traditional character rather than of any claim it could have to truth (78). If roses could reason they should infer the immortality of gardeners. "because never in the memory of a rose was a gardener seen to die!" The medieval encyclopedias compiled by such men as Isidore of Seville, Rhaban Maur, Herrad of Landsberg, Hugh of St. Victor and Vincent of Beauvais are full of extraordinary allegations, strange mixtures of fact and fancy, curious in the extreme, and bearing ample evidence of an utter carelessness about verilying observations and experiences. ${ }^{1}$ Even the more distinguished of these men,-Albert the Great, for example, whose scientific knowledge was remarkable,-were not above such puerilities. Great mechanical inventions like the telescope and microscope could alone give men that passion for the natural sciences which is characteristic of modern times. But the thirteenth century made none of those discoveries: what wonder then that it did not largely use or profit by inductive methods? The fault is due to a variety of causes which we are not called upon here to investigate; assuredly, however, Philosophy cannot reasonably be blamed for failing to perform a task that was not within its competence.

But, like science, like philosophy: Observations. accurate though commonplace, could and did lead to legitimate synthetic views: Phenomena like the transformation of wine support the hylemorphic

${ }^{1}$ Willmann, Didaktik, v. i., pp. $27 j$ and fol. 
theory of a twofold constitutive element in bodies, primal matter and substantial form. On the other hand, erroneous conceptions of fact engendered false, fanciful generalizations, such as the whole cosmology of the celestial bodies, the theory of the four sublunary elements and all that is involved in it (Section 15). Accidentally, no doubt, such false data could have led to true conclusions: Ex vero non sequitur nisi verum; ex falso sequitur quodlibet.

Furthermore-and this is a point that deserves attention-as the forms of all nature appeared to be eminently simple in character, thanks to the childish and superficial observations of that age. those people easily flattered themselves that they had wrested from nature practically all her secrets! Hence the striking tendency to hasty generalizations. and the mania for making the facts of experience square with the needs of some preconceived theory in order to fit them by force into the current philosophical synthesis. Such procedure is against the nature of things : it is like trying to build the dome of an edifice before the foundation.

Those vices of observation and generalization reached a climax in the hollow and inflated science of the epoch of the decadence, and exerted there a most fatal influence on the destinies of scholasticism (Section 19).

\section{SECTION 10.-SCHOLASTIC PHILOSOPHY AND THE PROBLEM OF UNIVERSAL IDEAS.}

52. The definitions we have so far examined (Sections 3-9) all contain a "soul of truth." Those of them that aim at connecting philosophy with some body of doctrine, such as theology or the special sciences (Sections 8 and 9) are deeper in insight and richer in meaning than those which try to define it 
by its relation to some superficial non-doctrinal element (Sections 3-7). Still, neither of the two classes alone, nor both combined, can satisfy anyone who wants to understand scholasticism in itself and to get at its real genius; they have all the common drawback of defining scholastic philosophy by that which is not philosophy (7). We cannot reach the heart of the system without familiarizing ourselves with the answers which scholasticism has given to the great philosophical questions raised by human enquiry, and seeking in these answers the character of the scholastic system. "It is clear," writes Willmann, " that the principle of development in medieval scholastieism is to be sought, not in its relations with antiquity, or in its theological aspect, but in the domain of its purely philosophical speculations." 1 But there are two senses in which the word philosophy is not uncommonly used (4). In its stricter meaning it is a complete and systematic collection of theories explicative of the universal order of things (55). It is, however, also taken to mean not the complete system but one or more isolated doctrines, answering to one or more of the problems raised by philosophers.

53 . It is from this second point of view philosophy is regarded by those who reduce scholasticism to an endless dispute about Universals. Hauréau takes this controversy for the scholastic problem par excellence. He wants to know nothing further from the long procession of doctors who pass over his pages, than their opinions on the three questions proposed by Porphyry. The scholastics, says Taine, went mad over the question of the universals, "the only one bequeathed to them," "so abstract, and so confusingly complicated by the /hair-splitting

I " Es wird ersichtlich dass der Nerv der Entwickelung der Scholastik im Mittelalter wider in ihrem Verhältnisse zum Altertume, noch in ihrer theologischen Seite zu suchen ist, sondern im Gebiete des eigentlichen Philosophierens." Geschichte des Idealismus, t. ii., p. 349 . 
discussions of the Greeks." 1 Or, again, according to 11. Penjon: Philosophy found itself reduced, "in its ultimate analysis, to controversies like those between nominalists and realists, so obscure that wo can nowadays scarcely understand the extraordinary amount of interest at that time attaching to them." But M. Penjon is sadly mistaken : the problem about the nature of the Universal is the eommon inheritance of all philosophies: we find it in India as well as in Greece, in the Middle Ages as in the modern epoch. amongst Kantians and amongest Cerman panthejsts. Even those, howerer. who, with Haureau as against Penjon, show a juster apprectation of the real interest and significance of those time-honoured controversies, do not go far enough by merely pointing to them as forming "the seholat tic problem." To linderstand and define a sistem of philosophy it is not enough to indicate the problem or problems it deals with: the solutions offered in it should be also outlined. Willmanm, for example, takes aleount of those solutions. when he teaches that the dominant note of the scholastic philosophy is " the reconciliation of idealism and realism by the immanence of the idea in the sense reality." 3 The notion conveyed in those few words by the lamed professor of Prague is at once accurate and forfound: we believe, however, that it is incomplete.

54. The early medieval philosophers discussed this problem of the universals according to the wellknown terms in which it was raised by Porphyry in his Isagoge. Now. the Alexandrian philosopher divides the problem into three parts: (1) Do genera and species really exist in Nature, or are they mere

'Hist. de li"litter. Inglaise, t. iii., p. 222.

l'enjon, l'ricis d'histoin de philosophic', 1. 17t.

" (ieschichte des Idealismus, t. ii., p. 322.

'It is completed fully by the author's brilliant exposition of scholasticism in sections $; 0-73$. The author's attitule. moreover, is explained by the general point of view of the whole work as inclicated lyy the title. 
creations of the mind? (2) If they subsist really, are they corporeal or incorporeal things? (3) And, finally, do they exist apart from the things of the world of sense, or are they realized in those things ? "Mox de generibus et speciebus illud quidem sive subsistant sive in nudis intellectibus posita sint, sive subsistentia corporalia sint an incorporalia, et utrum separata a sensibilibus an in sensibilibus posita et circa hæc consistentia, dicere recusabo." It is quite plain that this text of Porphyry's is completely within the domain of metaphysics. In the first question-on which the remaining two hinge-it is the absolute reality of the universals, their existence or non-existence that is in dispute. It is in this crude and undeveloped form we find the question treated in early scholasticism. Its first disputants directed their attention exclusively to the ontological aspect of Porphyry's alternative; the one party reduced universals to things pure and simple, the other to mere fictions or words. ${ }^{1}$

But it would be flying in the face of history to confine the activity of the early centuries of scholasticism to one monotonous dispute about the Universals. What, for example, does history tell us of Boetius, the great educator of the early Middle Ages ? That he was not merely a professor of Logic, but also a master of Physics, of Metaphysics and of Psychology. His scholars learned a great deal more from him than the various meanings of the formulæ of Porphyry; they learned the distinction between sense and intellect, the theory of passio, the definition' of person, substantial composition, the principle of causality, and so on. Many of those theories were of course wrongly understood, like the matter and form theory ; others were incomplete, like his theory of causes;

${ }^{1}$ Compare our study on Le problème des unitersaux dans son évolution historique du IXe au XIIIe siècle (Arch. f. Gesch. d. Philos., I 896), also our Histoire de la philosophie médiévale, pp. I67-173. 
and the whole collection of them wanted that unity which the synthetic genius of the thirteenth century was afterwards to give them. But even what the early scholastics knew of them is quite sufficient to vindicate these philosophers from the charge of exclusivism. Nejther they nor their successors ever allowed themselves to be hypnotized by a phrase from Porphyry-like those Indian nircanists who lull themselves to unconsciousness by the monotonous repetition of unmeaning formula.

Then, if we follow the question of the Universals through the golden age of scholasticism we shall see at once that it entirely shakes off the shackles in which it was bound up by the Alexandrian philosopher, and, after his example, by his earlier medieval commentators also. At the end of the twelfth century the metaphysical point of view was completed by the development of the criteriological and psychological aspects of the question - the aspects which alone bring out clearly to view the real value of universal notions. ${ }^{1}$

There is nothing more interesting in the history of the ninth to the twelfth centuries than the gradual widening of the scope of this controversy. The full and complete solution of the problem raises, one after another, delicate questions in physics, metaphysics and psychology. It has a very intimate connection with the theories of Essence, Individuation, Abstraction and Exemplarism. The scholastics of the thirteenth century understood all this; and far from lessening the importance of the whole question, they studied its influence upon all the various organic theories of their philosophical synthesis. The question was no longer an isolated one; it became an organic portion of one rast system (65).

${ }^{1}$ Many of those who define scholasticism by the problem of the universals have failed to grasp the real meaning of the controversy. This is the case with Mr. Clifford Allbutt, in his brochure, Science and Mcdicial Thought (Cambrilge, I893), p. $3 \mathrm{I}$. 
But yet it was only one element of the system. This latter included a large number of other elements as well : theological speculation on the divine attributes; metaphysical theories on Being, Substance, Cause, Individuation, Order, Categories ; controversies in Physics about Matter and Form; discussions on the origin and growth of knowledge, on Morality and Beatitude; those and many others besides, which could never have arisen out of Porphyry's three questions. All this will be made more manifest in the course of the following pages. We can understand, therefore, with what justice it has been described as " a sort of conspiracy against history to single out from scholasticism some special ideological question, the universals, for example, as Cousin has, or the relations of sensation to pure ideas, as M. de Gerando has, and to draw from these a general appreciation of the philosophical movement in the Middle Ages." "

${ }^{1}$ Morin, Dictionnaive de philosophie et de theologic scolastique au moyen age (edited by Migne, 1856), p. 22. To define scholasticism, Morin has recourse to two methods of procedure: (I) he studies the developments of the concepts of Being and Substance in their relation to Dogma; (2) he interprets the scholastic applications of ontological data to the sciences. Ibid., p. 23. 


\section{('HAP'TER II.}

\section{DOCTRINAL DEFINTTES.}

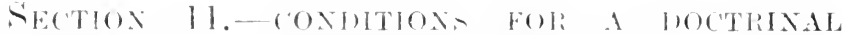 HEFIXITIOX.}

jis. Foremer is not a more anllection of theories about some special object, a simple juxtaposition of fragments of linowlestere an enerclopedia upon a given subject. It is. strietly spesting, a srstematized body of knowledge. that is.-according to the

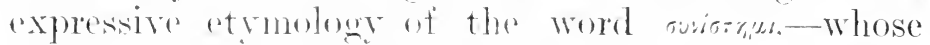
various parts of elements hold or hang together, hamonize and fit into one another like the cogs and wheels of a pien of machinery. It is only on condition of such harmony that the manifold conclusions of a scienee can be reduced to umity, and thus establish order in the mind.

So it is with all philosophies worthy of the name. The strongest of the great historical systems are those that were most firmly knit-the Upanishad system, the Aristotelian, the Neo-Platonic, the Cartesian, the leibnitzian, the Kantian systems; and each has had its special character and tendency impressed upon it by the organie unity of its theories no less than by these theories themselves. Scholastic philosophy in its golden age may be justly considered as one of those great convergent solutions of the "nigma of things.

56 . 'To raise all the great fundamental questions of philosophy. and to reduce all the answers to unity ; 
such are the two essential tasks of every philosophical system. System, as such, must be defined by the presence of both those elements. In order to define this or that particular system, Scholasticism, for example, as opposed to Kantism, we must examine into the body of doctrines peculiar to each, and study these doctrines both in themselves and in their mutual relations. It is evident that the solutions of the one system are not those of the other, and that in order to judge of them we must understand them.

Those considerations make it clear that before we can bring together the elements of a doctrinal definition of scholasticism we must first interrogate its teachers on their fundamental theses, and secondly, that a doctrinal definition must needs be a terminal, not an initial one. The reader will therefore find in the following paragraphs an attempt at a brief exposition of scholastic teaching. And since a body of philosophical doctrines presents very great complexity, our definition of the scholastic system will be necessarily complex, even though it be confined to a mere outline. A definition ought to be brief, no doubt, but the logical demand for brevity must be understood in a relative sense.

57. To convince ourselves of the complexity of a body of philosophical doctrine, we need only consider that the characteristics commonly employed to outline a philosophical system, describe in reality only some particular doctrine or group of doctrines within the system. When Victor Cousin, for example, classifies philosophical systems into sensualism, idealism, scepticism and mysticism, the first two groups can have reference only to one single order of philosophical questions, that of the origin and certitude of knowledge. ${ }^{1}$

1 Mysticism in Cousin's thought stands for something too vague to admit of its being discussed as a system of philosoply. As for scepticism, it is not so easy to construct a doctrinal system out of the very denial of the possibility of doctrine! 
Similarly, Renouvier's six fundamental oppositions employed as a basis for his Esquisse d'une classification systématique des systèmes philosophiques,' are far from being each an adequate characteristic of a system. Of these oppositions: materialism and spiritualism; evolutionism and creationism; liberterianism and determinism; endaemonism and obligationism ; rationalism and fideism : finitism and infinitism : each regards one doctrine alone, replies to one question alone. So true is this that the various alternative couples in question are quite compatible with one another in the same system, and that some of them are actually found united in every system. For example, scholastic philosophy is at the same time spiritualist, creationist, libertarian. etc.; while stoicism is materialist. evolutionist, determinist, etc. Not to mention that it is quite possible to multiply such types of fundamental opposition between different philosophical systems.

It is, indeed, true that some determining characteristics seem better adapted to designate a whole system of philosophy than others, as when we speak of pantheism or positivism. Yet this is not because these latter individualize the synthesis as such, in the entirety of its principles and doctrines, but rather because they designate some one or other of its most salient doctrines. Strictly speaking, pantheism is not a system, for it decides only one doctrine of a system, that of the unity or plurality of all being; but what is true is this, that there are systems which are pantheistic, being at the same time either materialistic like that of David of Dinant, or idealistic like that of Hegel. Similarly, positivism pronounces upon one single problem : that of the origin or source of all our knowledge; but everybody knows that Comte's positivism and Spencer's positivism are full of other equally important doctrines bearing upon

12 vol., I 885. 
problems quite other than the positivity of science. We see then that in order to delineate a system of philosophy in its entirety we must review all its fundamental theories, give a critical estimate of them, and thus distinguish them from those of other systems on the same subjects. The idea of the fundamental antinomies spoken of by Renouvier, may indeed be utilized, but only on condition of applying them to the special questions overlooked by that author, and of insisting that the members of the various couples enumerated are disjunctively compatible with one another in the same system.

58. So long as we regard a number of different systems under one single aspect, we may group them in categories: Lange has written the history of Materialism, Willmann that of Idealism. But if, on the other hand, we take any system in its doctrinal fulness, it will be found to form a unique and individual whole. We can give it a singular name, call it Platonism, Thomism, Kantism; but define it we cannot except by specifying its various doctrines by their distinctive characteristics. The ideal thing would be to give a sketch of all the doctrines; we should then know how and why the system of St. Thomas differs from that of Scotus or from that of St. Bonaventure. But as we have said above and will show in the sequel, there is such a remarkable agreement amongst the great doctors " of the thirteenth century upon all fundamental questions, that their respective syntheses may well be considered as so many species of one and the same genus: scholasticism.

59. Let us now endeavour to apply to the common data of the scholastic synthesis the process of definition just outlined; and for this purpose let us follow scholasticism through the great departments into which its leading exponents have divided all philosophy. Of course our outline can have no pretension 
to completeness of exposition; it will not give in a few pages what the ablest authors have expounded in volumes. It will be mainly historical, and will aim at a faithful presentation of the great organic principles of medieval scholasticism. People like Taine who are ignorant of these principles see in scholasticism only a heap of absurdities. Those who understand them only partially are often mistaken about the meaning of scholastic theories; and this is the case with a large number of our modern historians of scholasticism as soon as they approach the study of it in detail.

\section{SECTION 12.-METAPHYAICS.}

60. Although metaphysies is the product of the highest intellectual abstraction, yet it has for its chief object the substance or essence of the things of sense; and accordingly. so far from resting on the quicksands of fancy, it is anchored to the firm rock of reality. If, however, it deals with the world of sense (as material object) - the world which will forever remain the proper sphere of all human investigation (S7)-it is only by ignoring the properties based upon change that it does so, and by grasping the substance alone, the being and the constitutive principles of things (as formal object). "Philosophi erit considerare de omni substantia inquantum hujusmodi." I

Secondarily, metaphysics deals with non-substantial being, with adventitious or accidental being. 'Thus we justify the definition of metaphysics as the science of being that is immaterial by abstraction, of being taken simply as such, of being as stripped of everything with which the purely sensible order endows it.

${ }^{1}$ St. Thomas Aquinas, in IV. Metaph., lect. 5 . 
61. Being may be studied under certain very general aspects which serve to bring out clearly the meaning of so simple and all-embracing a concept. These are called the transcendental attributes of being. Such, for example, are the aspects of unity, goodness and truth (unum, verum, bonum).

Furthermore, being is not a something that is changeless and merely static: it must be studied not merely in its state of repose but also in its inception or becoming, in its evolution or change (in its fieri as well as in its esse). The things of experience have only a finite degree of reality, and even that not actualized all at once. The constant evolution or change to which things are apparently subject is an indication that they are continually gaining or losing reality, that they can appear and disappear. Take a thing in any state whatever : that state will evoke the idea of a prior state in which the thing was not what it now actually is. Before actually being, it could be, what it is. A chemical combination presupposes others, and can lead to still further combinations of matter. Before a man reaches the ripeness of age and knowledge and virtue he must have passed through all the successive stages of their infancy and youth. Now, in order to be able to pass from A to $\mathrm{A}^{1}$ the being must have already possessed in A some real principle of the change; it was really capable of receiving or undergoing a new determination or modification; it possessed the capacity, or was in the capacity of becoming what it now actually is. Actuality (actus) is therefore the degree of being

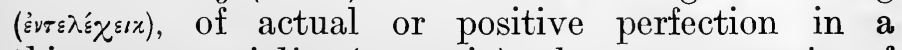
thing; potentiality (potentia), the mere capacity of receiving some such complement of being or perfection-it is non-being, therefore, if you will, yet not mere nothingness, but such non-being as implies within itself the real principle of a future actualization. This actualization, this passage from the potential 
to the actual state, bears the technical name of movement, defined by the scholastics after Aristotle as "the actualization peculiar to a being which is still formally potential." "Convenientissime Philosophus definit motum dicens quod motus est actus existentis in potentia secundum quod hujusmodi." 1

The pair of ideas "potency and act" thus became synonymous with "being determined and being determinable." In this general sense it passed beyond its original signification of a process of becoming, an organic evolution or fieri, and served to interpret all compositions, without exception, of all being that is contingent or limited in its reality. It was regarded as a primordial distinction, of universal application in the order of the real being, and thus became an exceedingly fertile conception in metaphysics. Substance and accident, essence and existence, specific essence and individual, are so many examples of the "potency and act" couple. Nor is this fundamental distinction peeuliar to metaphysics; it effects an entrance into other domains, into logie, physics, psychology and ethies ; and everywhere it expresses the same elemental relation of the "determinable" to the "determined": the genus is to the species, the corporeal matter to the soul, the passive intellect to the active, the free act to its subjective end, as "potency" is to "act."

62. The first important application of the "potency and act" couple is found in the great classification of things into substances and accidents. The substance or substantial being is the being that exists without needing any other being in which to inhere for its existence, and which serves as subject or support for other realities. Man, horse, house, are substances ; whereas the virtue of the virtuous man, the colour of the horse, the size of the house are accidents. These adventitious realities (ac-cidere) are ontological

1 St. Thomas, In III. Phys., lect. 2. 
determinations (actus) of the substance (potentia). Here we touch upon the famous Aristotelian classification of the categories of being. And as a matter of fact the scholastics took up and developed very considerably the study of the nine accidental predicaments, especially those of quality, quantity, relation, time and space.

The study of quality (accidens modificativum substantiæ in seipsa) raises some important controversies passed over by Aristotle, notably that regarding the distinction between a substance and its powers or faculties of action. Can action proceed directly from the substance in contingent beings, or do these act through the medium of faculties? This question was hotly debated in the thirteenth century, and its solution is of great importance in psychology. Opinions were divided. The Thomists held that there is a real distinction between substance and faculty, so that the actual operation as such is a determination or actus which affects the substance not directly but through an intermediary, the faculty: "operatio est actus secundus." St. Bonaventure, on the other hand, steers between Thomism and the old Augustinian doctrine of the identity of the soul with its faculties; while Duns Scotus deals with the matter in a way peculiar to himself, by the distinctio formalis a parte rei (65).

63. The real distinction between matter and form, the two constitutive principles of corporeal substances, is likewise a particular application or aspect of the distinction of "potency" and "act." The doctrine of matter and form is regarded by the scholastics, just as by Aristotle, as belonging properly and primarily to physics (74). Wherever there is change throughout nature, there must be found matter and form. The piece of oak is the passive recipient subject (materia) of the shape or figure (forma) introduced by the carver's chisel. But these are 
respectively a "second" or "derived" matter and form. For the oak itself one day made its first appearance and grew to be a tree by the gradual assimilation into the acorn of innumerable chemical elements - themselves substantial beings-which were gradually transformed into cells of "oak." And so we may ascend the path of change indefinitely. Now, in order to explain the transformation of substances, their chemical combination and decomposition, Aristotle demanded, in the various substantial realities which appear and disappear, a permanent substrate which he called primary matter

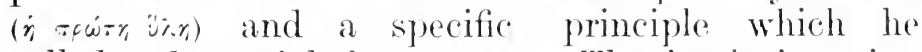
called substantial form (100). The intrinsic union of matter and form gives rise to the corporeal substance. The matter being the principle of indetermination and the form that of determination. there is an unmistakable relation, in the domain of corporeal substances, between these two pairs of ideas. matter and form on the one hand. and potency and act on the other.

But is composition from matter and form applicable outside the corporeal order of things? Does it hold for incorporeal substances, so as to be thus a mark of all contingent being? Here we reach a point at which the Thomistic and Franciscan teachings bifurcate. The latter completely identify potency and act with form and matter, and therefore represent the latter composition as the all-pervading, necessary property of all created things whatsoever. This is not the view of Albert the Great and St. Thomas. These doctors teach that primary matter enters as a constituent into corporeal substances only; it is the foundation of spatial extension, of multitude, and of the imperfection of bodies generally. In this they are rather followers of Aristotle, as their opponents are of Avicebron.

There was general agreement in recognising an 
existential dependence of matter on form-though some held the contrary opinion (Henry of Ghent, for example). St. Thomas taught expressly that God could not bring primary matter into existence without some substantial form as determining principle: it would be intrinsically impossible to do so, seeing that the potential, as such, cannot be in act.

The converse question-whether form is necessarily allied with matter, or whether a form of itself alone may not constitute an incorporeal being ${ }^{1}$ assumed a special importance in scholasticism, on account of its intimate relation with the doctrine on angels. These latter-superior intelligences, free from the imperfections of corporeal life-form an intermediate step between God and man in the hierarchy of essences. Indeed it may be said that scholasticism has constructed, upon the purest principles of intellectual and volitional activity, a psychology, or rather an "eidology" of 'angels, which has nothing in common with Aristotle's vague conjectures on the intelligences that moved the world's spheres. How did the philosophers of the thirteenth century conceive the composition and nature of the angels?

There were different theories. Although unanimous in ascribing to the angelic nature a composition of potency and act, which all regarded as the essential note of contingent being, they were divided upon the question of a real composition of matter and form. In opposition to the Franciscans whose views we have just mentioned, the Thomists asserted that the angels are "pure" or "separated" forms. And here is their reason: Since it is the form that actualizes the matter and gives the compound its

${ }^{1}$ Or even-in the minds of certain scholastics of a later periodsimple corporeal beings, such as they conceived the heavenly bodies to be. 
perfection and not vice versa, there can be no contradiction in the concept of forms subsisting apart from any union whatsoever with matter. Such separated intelligences, moreover, are not only intrinsically possible but also contingent and finite, for their essence is limited by their existence: "quia forma creata sic subsistens habet esse et non est suum esse, necesse est quod ipsum esse sit receptum et contractum ad determinatam naturam. Unde non potest esse infinitum simpliciter." 1

64. What we have been just saying suggests an examination of the functions attached to the form by scholasticism. Its first function in the real order (whether of corporeal or incorporeal being), is that constitutive causality which we have been explaining (formal cause, id per quod aliquid fit); it makes the

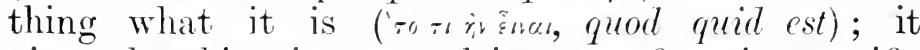
gives the thing its natural impress, fixes its specific rank and its degree of perfection. Furthermore, it is in a special way the principle of the activity of the thing (natura), and the source of its faculties and operations. The form is also the seat of finality, of that objective, innate tendency which impels the being to realize some specific end by the exercise of its activities.

From all this, it is easy to understand that the form is the principle of unity in a being. And particularly in corporeal being it is the form that gathers up into one unique subsistence the scattered elements of extended matter. But what exactly is the scope of this unitive function of the form ? Or, in other words, can one and the same corporeal being receive the intrinsic determination of more than one form ? The answer of St. Thomas is in the negative, and is therein strictly peripatetic; we have his fundamental argument in these words of the Summa Theologica: "Nihil est simpliciter unum, nisi per formam unam

\footnotetext{
${ }^{1}$ St. Thomas, Summa Theologica, ra, q. 7, a. 2.
} 
per quam habet res esse."1 But this solution was novel, for it ran counter to the teaching of Alexander of Halès, of St. Bonaventure and of Albert the Great himself; and it drew forth the most energetic protests from the Franciscan schools (31). Most of the thirteenth century scholastics and a considerable number of those of the fourteenth, admitted that the various degrees of perfection found in one and the same being have distinct forms corresponding to them, and this without detriment to the complete and perfect unity of the being.

As for the matter, seeing that it is the recipient of all determinations, it must itself be destitute of all. It is the form that leavens it from within, as it were ; and every form is some one realization of the inexhaustible potentiality of the recipient. ${ }^{2}$

65. The multiplication of individual beings in one and the same species, gives rise to two problems of fundamental importance: the relation of the individual to the universal, and the question of the principle of individuation. Now, those two problems were organically connected with the doctrine of the distinction between potency and act.

The "universals" controversy was practically decided before the thirteenth century : scholasticism unanimously accepted the solution arrived at in the twelfth. "The individual is the real substance; the universal derives its ultimate form from the subjective work of our minds." The most subtle dialecticians, not excepting Duns Scotus himself with all his daring differences of view, take no exception to those scholastic conclusions. No one, however, is more exact and logical in those delicate matters than the Angelic Doctor. It is as a tribute of homage to his wonderful powers of exposition, and not as

1 ia, q. 76, a. 3 , c.

2 The "matter and form" couple was of course freely transported from the real to the ideal order, where "formalis" is synonymous with "actualis," and " materialis " with "potentialis." 
crediting him with a great discovery, that pusterity has called this moderate realism by the name of Thomistic realism. In any case, among all the solutions of the famous " universals" problem, it is the one that harmonizes best with scholastic philosophy.

Appropriating a formula which was current in the scholastic repertory, St. Thomas sums up thus the relations of the individual to the universal: The reality of essences may be viewed in three states: ante rem, in re, post rem, or, in the language of Avicenna. ante multitudinem, in multiplicitate, post multiplicitatem. ${ }^{1}$ The universals ante rem are defined in the theory of Exemplarism with an Augustinian largeness of view that borders on the erroneous system of Avicenna. The universals in re represent the physical side of the problem, the theory of the mere subsistence of individuals with the principle of their individuation. ${ }^{2}$ The universals post rem are the fruit of a subjective elaboration to which the objective aspects of things are subjected by the activity of the mind when it considers things apart from their individualizing conditions. Formally (formaliter) the universal exists only in the mind, but it has its foundation (fundamentaliter) in the things.

With the exception of the "terminists" or "nominalists" of the fourteenth century, who denied the real validity of our universal representations, thus showing the first signs of the scholastic decadence, the scholasties generally drew a distinction, in all created substances, between the essential determinations which reappeared identically in every representative of a species, and the individualizing

${ }^{1}$ Logic, Venice edition, I 508 , fol. 12, V.A.

- St. Thomas thus lay's bare the fundamental error of exaggerated realism, which was completely eradicated in its extreme form : "Credidit (Plato) quod forma cogniti ex necessitate sit in cognoscente eo modo quo est in cognito, et ideo existimavit quod opporteret res intellectas hoc modo in seipsis subsistere, scilicet immaterialiter et immobiliter." Summa Theol., Ia, q. 84 , art. I. 
determinations which distinguished each representative from every other within the species. The former are to the latter as the determinable is to the determinant, as potency is to act. What is the distinction between them? In the view of St. Thomas the concepts of specific essence and of individual essence correspond to different constitutive realities in the individual thing (distinctio realis). Others conceived the distinction as a merely logical one. Duns Scotus advocated the existence of a distinctio formalis a parte rei, as if, anterior to the act of thought, the object of each universal idea possessed a certain separate unity in the things themselves (a parte rei).

66. But there arose another problem which was discussed with the greatest possible ardour in the thirteenth century: what is the principle of the individuation of things? In other words, if we are to reconcile the stability and abiding identity of essences with the endless diversity and wonderful variety of their individual realizations in nature, whence or how does it come that there are innumerable individuals in one and the same species? Here we have a scholastic controversy par excellence, for it presupposes, at least in a certain measure, the peripatetic solution of the problem of the universals. The medieval philosophers all admitted that within any species the basis of individuation ought to be essential and intrinsic; but difference of views arose as soon as the question was asked whether it is the matter or the form, or the union of both principles, that accounts for the individuation of things.

We find the Aristotelian system in St. Thomas Aquinas, but so completely amplified and perfected that the new developments almost entirely eclipse the borrowed portion. Aristotle had shown why the form, being an indivisible principle, cannot multiply itself numerically; but he had left in 
obscurity the individualizing function of the matter. St. Thomas explained that the individualizing principle is not the matter in a state of absolute indetermination-as unskilled or hostile interpreters of Thomism have often alleged, in the hope, perhaps, of discovering a contradiction. It is the materia signate, that is to say, the primary matter endowed with an intrinsic aptitude to oceupy a definite portion of space. ${ }^{1}$

For St. Thomas, therefore, the question of individuation confines itself to the world of corporeal things. More logical even than the Stagyrite, he holds that in the hierarchy of separated forms each individual constitutes its own species. ${ }^{2}$ As regards the heavenly bodies, composed of matter and form, and nevertheless each unique in its species, the view of St. Thomas can only be understood by referring it to the general principles of scholastic physics (78).

Others among his contemporaries arrive at different conclusions. St. Bonaventure finds the principle of individuation in the combined action of both constitutive prineiples, matter and form; Henry of Ghent, in a negative property of each substance, marking it off from every other substance; Duns Scotus, in a positive disposition of the final form to assume such or such individuality, to be this thing. And as for the multiplication of individuals in supramaterial species, this can have no difficulty for those who admit in them a physical composition of matter and form.

67. A fourth sort of composition in being, not referred to by Aristotle, gave rise to some exceedingly delicate scholastic discussions: the composition of essence and existence. The relation of the concept of essence to that of existence was not called into

1 St. Thomas, Op. IX. De Principio Individuationis.

2 Zeller, Die Philosophie der Griechon, II., p. 239, n. 3. 
question; nor the relation of a possible essence to an existing essence; between the terms of those comparisons a real distinction was admitted by all. But we may pursue further our analysis of being, and enquire whether, in an actual being, its fundamental, constitutive reality (essentia, quod est) is one thing, and the actuality or act by which that reality exists (esse, quo est), another thing. And on this point opinions differed. St. Thomas advocated the doctrine of a real distinction: in God alone, the Actus Purus, are essence and existence identical; in created being, on the other hand, whether spiritual or material, the perfection signified by the word "exists" is confined and circumscribed within the limits of the essence which it determines. "Unde esse earum non est absolutum sed receptum, et ideo limitatum et finitum ad capacitatem naturæ recipientis." I Essence is to existence what potency is to act. ${ }^{2}$ But all being is actualized only in the measure in which it is capable of actuation; for the degree of actual being is measured by its corresponding potentiality. Hence a contingent essence can receive existential actualization only within the limits of its contingency.

Looking at the general structure of Thomism, we find this theory of the real distinction very closely connected with some of the most fundamental theses of scholasticism. Moreover, it throws into bold relief the contingency of the creature; and above all, it safeguards unity of existence in beings composed of matter and form, i.e., of consubstantial, incomplete and mutually irreducible elements, as also in beings that exercise their activities by means of faculties really distinct from their own substance. Nevertheless we find among the various exponents

\footnotetext{
${ }^{1}$ De ente et essentia, c. 6.-Cf. the unfinished opusculum De substantiis separatis.

2 See Cajetan's commentary on this passage.
} 
of scholasticism a widespread and energetic opposition to this particular Thomistic thesis. The whole Franciscan school especially denied any real composition of essence and existence.

68. Another theory closely related with that of power and act is the theory of causes. I cause is whatever "xerts any real and positive influence in bringing anything to pass. Within the cycle of change in the world of contingent things, all being, whether in its substantial constitution or in its accidental states. oxists in its caneses or in potency, before it appears realised or in its actual state. Its realization is its "passage from potency to act." But a thing considered in a potential state as regards any determination, camnot give itself that determination. It must receive it under the influence of some other being already in act. “ Q Quidquid movetur ab alio movetur." "This extrinsic principle of change is alled an efficient couse.

Under its influence, the thing (matter) that is in potency to receive some perfection (form), i.e. capable of receiving it, does actually receive it. By their intimate union and intercommunication, the recipient subject and the communieated perfection exert a constitutive causality on the new being, or on its new state. They are the constitutive causes, either of the substance of the thing itself (primary material cause, substantial formal cause), or of some attribute of the thing (secondary material cause, accidental formal cause).

Finally the efficient cause is solicited by some good to be realized through its action (final cause), and develops its activity in that direction. This stimulation of efficiency by an end or motive is clearly evident in the wonderful order and beauty of the universe. ${ }^{1}$

${ }^{1}$ Beauty is the manifestation of order. Its perception occasions esthetic pleasure. Scholasticism, while not neglecting entirely the study of the heautiful, gave it only a secondary consideration. We shall deal with it in the second part of the present work. 
If order were a rare exception it might possibly be the outcome of a chance coincidence of motor causes. But its endurance and its universality can only be explained by an internal tendency which co-ordinates the actions of the operative causes, and thus secures the realization of the designs of nature. It is this inherent, intrinsic finality that explains the constant recurrence of natural phenomena and the preservation of the various species, organic and inorganic, in the domain of physics; the innate tendency of the mind towards truth, in criteriology; the natural inclination of the will towards the good, in ethics. And so, the theorem of finality appears in scholasticism as the crowning and perfecting doctrine of the "philosophy of being."

\section{Section 13. - THEODicy.}

69. The human mind can have no pretensions to a proper knowledge of what is beyond corporeal being $(87,42)$. Even metaphysics itself, the highest of all the sciences, has for its primary object the substances of visible nature : by mental abstraction it considers their being apart from matter (60). Still, on the other hand, the profession of an absolute agnosticism as regards the essentially Immaterial Being, the Deity, is a philosophical error; and scholasticism has successfully avoided it. The very same mental operation which attains to being that is abstract negatively or by abstraction, yields at the same time a series of concepts which can be applied by analogy to being that is immaterial positively or of its very nature. ${ }^{1}$ And this explains and justifies the title of (rational) Theology which we find in Aristotle ( $\left.\theta_{\text {soi.0y } 6 x^{\prime}}\right)$, in the Arabians and

${ }^{1}$ St. Thomas, In Lib. Boetii de Irinitate, q. 5, a. I.-Cf. Mercier, Ontologie, p. viii. 
occasionally in the scholástics, as synonymous with metaphysics.

70. We find as early as Aristotle the well-known classification of beings into two great categories: on the one hand, beings partaling of a mixture of potency and act, beings which, before possessing a perfection actually, exist already in a prior state in which they are destitute of it: on the other hand, the pure act, actus purus, exempt from all potentiality, namely, God. The medieval doctor's developed and improved those Aristotelian data, employing them in a domain unknown to Aristotle. Uniting them with certain theories of the Fathers of the Church, especially of St. Augustine, they built up a new theodicy which is certainly one of the finest contributions of medieval thought to our intellectual inheritance from antiquity. The peripatetic notion of an immovable motor, wrapped up in inaccessible self-contemplation was supplanted by the theory of a self-existent Being, infinite in Its pure actuality. Apart from a few weaker spirits in the decadent epoch, the scholastics all admit that the consideration of the actual contingent universe can convince the human mind of the existence of God (a posteriori proofs).

71. In like manner, it is by observing creatures that we can know anything about the divine essence. Reason tells us that all the perfections found in creatures must be in God also-analogically and eminently (analogice and eminenter). Furthermore, the study of the divine attributes is but a series of corollaries from the study of His aseity. Thus, for example, God is perfect science; He is also perfect love-contrary to what Aristotle taught; and there is absolutely no doubt about His personality.

The multiplicity of the divine perfections is swallowed up in the unity of the infinite. But the scholastics differ in their conceptions of the kind 
of distinction to be admitted between those perfections-just as on the question of their relative pre-eminence. St. Thomas recognises a virtual distinction between the divine attributes (distinctio rationis cum fundamento in re); and, true to his intellectualism, he emphasizes the role of the divine science. Others, under the lead of Duns Scotus, introduce here the strange distinctio formalis a parte $r e i$, and attribute a preponderating importance to the divine will.

72. Regarding the relations between God and the world we notice still further points of difference between the peripatetic and the scholastic philosophy. The absolute subordination of the being composed of power and act to the being that is pure actuality, does away with the inexplicable dualism of finite and infinite, so obtrusive in Aristotle in common with the whole of pagan philosophy. This subordination is revealed in the three theories of exemplarism, creation and providence.

Exemplarism.-In the first place, God knows all things independently of their existence in time. Before realizing the universe He must have conceived the vast plan of it; for $\mathrm{He}$ has done all things according to weight and measure. God's ideas, says St. Thomas, have no other reality than that of the divine essence itself. Since His knowledge exhausts the infinite comprehensibility of His being, He not only knows His essence in itself (objectum primarium); He also sees the relations between it and creatures, its far distant imitations (objectum secundarium). If some scholastics have other views about the nature of the divine ideas, all agree that they are the supreme ontological foundation of contingent essences; not, of course, that we know things in God (ontologism), but because, in a synthetic view of all reality from the First Cause downwards, we see that the attributes of all created things 
necessarily reproduce or show forth their uncreated exemplar. The divine ideas are at once the ultimate reason of the reality of things, and the final basis of their cognoscibility: it is on them, therefore, that the certitude of our knowledge must, in its ultimate analysis, be found to rest. In harmony with the doctrine of the innate tendency of the intelligence towards truth as the final cause of its acts (68), those synthetic speculations reveal the favourite attitude of the epistemology of the thirteenth century, and points to the direction in which we ought to seek for the two great bases of its criteriological dogmatism. The influence of the Augustinian rationes aterna and of the Pythagorean speculations on numbers, may be easily detected in the theory of exemplarism.

Creation.-According to those divine ideas, the causce exemplares of the world, God produced from nothing, by His creative act, all contingent realities. Scholasticism here improved on Aristotle, not only by its concept of "exemplary" causality, which was incompatible with the immobility of God as conceived by the peripatetics; but also by its theory of efficient cause (id a quo aliquid fit).

In Aristotle, the efficient cause should be rather called the motor ${ }^{\mathrm{I}}$ cause ; for efficiency, in his concept of it, does not regard the production of the first or earliest recipients or subjects of movement. These are supposed to be eternal, as also the world which has resulted from their combination; and movement results necessarily from their conjunction.

In scholasticism, on the contrary, it is not merely the movement of things that falls under the influence of the divine efficient cause, but the very substance of those things, even in its deepest reality. Whether, further, we admit the necessity of a creation in time

${ }^{1}$ In modern scientific language a motor cause is one that produces local motion. It is taken here in a wider sense to designate the productive cause of any sort of movement or change ahatsocver.-Cf. n. 61. 
or, with St. Thomas, fail to find any evident contradiction in the concept of eternal creation-is a matter of minor importance.

Providence.-The Omnipotent Creator retains His sovereign power over the creature $\mathrm{He}$ has called into existence out of nothingness by the simple act of His all-producing will. While respecting the proper nature of every created being, He conserves its essence, co-operates with its activity (concursus congruens naturce creatura), and rules it by $\mathrm{His}$ Providence. He is also the final cause of the universe, but in a deeper sense than with Aristotle. All things tend towards God; a thesis intimately connected with the doctrine of the future life and happiness of man.

The application of Aristotelian metaphysics to the study of the Divinity gives the theodicy of the thirteenth century a depth and richness which neither the Fathers of the Church nor the early scholastics ever saw in it. It is really one of the most powerful affirmations of theism the world has ever witnessed. The God of the scholastics is no anthromorphic deity, "dwelling away in the clouds," and keeping the world-machine in motion : pantbeism makes merry over such fanciful imaginings, but these have nothing in common with the sublime conceptions of the thirteenth century.

\section{SeCtion 14.-General PHYSICS.}

73. The object of general physics in the ancient meaning of the word, is the synthetic study of the corporeal world. The great, striking phenomenon which enables the physician to rise above the endless details of nature, and to embrace it in one comprehensive view, is the movement or change of bodies. Metaphysics deals with movement as such (61); 
physics, with corporeal movements. These latter, as Aristotle taught, are of four kinds: the appearance and disappearance of substantial compounds (z'veo/; and poopi) ; qualitative change (ai, i.cisors); growth and

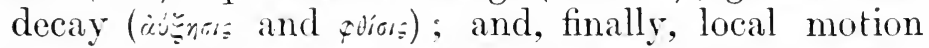
(copa), the movement par excellence, which the three other kinds presuppose. The concept of local motion occasioned controversies on time and space.

74. The theory of substantial change gives lis a very characteristic explanation of the evolution of nature. Difference of properties reveals a specific difference between corporeal substances. On the other hand, these substances change into one another and combine with one another to produce new compounds. specifically distinct from the generating factors: and these latter compounds in turn, under the unceasing action of surrounding agencies, are again resolved into their elementary constituents; the abiding identity of the primary matter through all the varying stages of the process, together with the diversity of specific forms, yields an adequate explanation of the visible facts (65).

In all the scholastic systems, the primary matter of the body is endowed with a fundamental relation to quantity. Quantity, or passive diffusion in space, is the first attribute of bodies, and it is regarded as a function of the primary matter-just as the reduction of the corporeal elements to unity is a function of the form.

The abiding identity of the primary matter does not offer any obstacle to its real diversification in the innumerable substances of the universe. To understand fully the mind of the scholastics on this subject we must remember that the transformations of substances follow a rhythmic gradation the stages of which are regulated by the finality of the cosmos.

75. This theory of the rhythmic evolution of 
substantial forms is beautifully developed in scholasticism. Matter is, no doubt, a treasure-house of potentiality, a pliable thing which assumes a succes sion of forms throughout any given series of compositions. But this plasticity has its limits; it follows certain lines. Nature will not change a stone into a lion; in its evolution it obeys a law of progress, the detailed application of which it is the mission of the special sciences to study, while the physician views it only in its generality. Or, in scholastic language, the primary matter is not deprived of one form to assume any other form indifferently, but only to be united to that particular form which corresponds with the immediately neighbouring type in the natural hierarchy of things. By reason of a special predetermination, the different stages traversed by matter are thus fixed in a very perfect way. Hence the teaching of St. Thomas that, antecedent to its union with the spiritual soul, the human body assumes a certain number of intermediary forms, until nature's work has thus rajsed the embryo to a state of perfection which demands the supreme informing principle, the spiritual soul, infused by Almighty God. This is simply the " natura non facit saltum" expressed in philosophical language: a simple but striking interpretation of the principle of cosmic evolution. Here also we are led into the full meaning of the formula: corruptio unius est generatio alterius.

This process productive of forms (eductio formarum e potentiis materia) is rightly regarded as one of the most difficult questions of scholasticism. Its greatest teachers are unanimous in admitting the intervention of a triple factor: the First Cause exerting the concursus generalis; the pre-existing matter disposed to receive the new form and give birth to the new compound; the natural agent or active principle, which actualizes the receptive subject. But there 
is little or no agreement as to the respective role of each of these three factors. St. Thomas lays stress on the virtus activa of the natural agent, and on the passivity of the matter. He simply reduces the problem of the appearance and disappearance of forms to that of the actualization of a potency in a pre-existing subject (61). The Thomistic teaching is thus opposed to the more ancient theory of the rationes seminales, defended by St. Bonaventure and by most of the earlier scholastics of the thirteenth century. The advocates of this latter cosmological hypothesis would maintain that God endowed matter from the beginning with certain active forces which are the seminal principles of all things, and whose gradual development in the bosom of the material universe accounts for the appearance of the innumerable material substances of nature.

76. However that may be, finality rules the whole series of substantial changes, and the universal order of things, just as it rules the activities of each individual being (68).

With the exception of a few realists of the twelfth century who were led into error by the poetical descriptions of the Timaus, the scholastics never regarded nature in the light of a real, individual, physical organism, after the manner of the ancients. As regards the ultimate term of the cosmic evolution, scholasticism finds an explanation, unknown to Aristotle, in the relation of the world to God. The existence of the creature can have no other end than the glory of its Creator. That glory finds its first manifestation in the contemplation of the universe by the Infinite Intelligence ; secondly, in the knowledge which other intelligent beings can acquire of the marvellous order of creation. Such is the elucidation of an enigma which Aristotle had encountered without being able to offer a satisfactory solution of it: how is God the final cause of the material universe? 
SECtion 15.-CELESTIAL AND TERRESTRIAL PHysics.

77. The spectacle of the heavens is imposing; chiefly because of the unending revolutions and apparent immutability of the stars. Influenced by the popular beliefs which held the stars for divinities, Aristotle regarded them as more perfect substances than those of the earth. He set up a distinction of nature between the former as being exempt from the laws of change, and the latter as being manifestly plunged in an ocean of change. Medieval philosophy espoused this a priori principle; and its vitiating influence is revealed in the three thirteenth century departments of special physics: physical and mechanical astronomy; the theory of sublunary matter; and the action of the heavens upon terrestrial substances.

78. The superior perfection of the starry universe is revealed firstly in its constitution and secondly in its local motion. The heavens are complete strangers to birth and death alike: the astral substance is immutable, exempt from generation and corruption. In philosophical language the theory runs thus: the heavenly bodies are indeed composed of primary matter and substantial form, but these two constitutive elements are here indissolubly united to each other.' And as primary matter, that receptive subject of those original determinations, cannot assume a new substantial form without losing the one it has (corruptio unius est generatio alterius), the indissolubility of that union explains both the impossibility of all transformation and the permanence of the starry bodies ; that is, of the fixed stars and planets: for the comets, whose irregular motions would not fit in with the theory, were regarded as a sort of atmospheric will-o'-the-wisps.

1 Some scholastics, posterior to the thirteenth century, attributed the immutability of the stars to their supposed simplicity. 
But the scholastics did not infer the eternity of the stars from their immutability, as Aristotle had done : their teaching on this point was an application of their general doctrine of creation (72); and they still more emphatically repudiated the view that would see in the star a divinity. On the other hand, however, they accepted this other corollary that each siderial type is unique: since the form here determines all the matter it is capable of informing, each star or heavenly body must be unique of its kind.

Just as their astronomical physies were adapted to their general principles on the constitution of bodies, so also were their celestial mechanies inspired by a priori considerations on the perfection of circular movement. The only sort of change observable in the stars is the local displacement due to their revolutions. And in fact, since local motion was regarded by both ancient and medieval physicists as a necessary manifestation of all corporeal essences, each specific substance should possess its own specific movement: here we have the theory of natural movements and natural places, one of the old antitheses to our modern mechanics. The theory simply means that if a body be displaced by an efficient cause, it will determine and direct its movement, according to its nature, towards the place which is natural to it.

The heavenly body, superior in its constitution to the earthly, has also a nobler sort of motion: its movement is circular. This is the most perfect of all motions, for the circle has neither beginning, middle, nor end; it is complete in itself, without further addition.

Without attempting a detailed explanation of the revolutions of the heavenly bodies, let us merely note that all the astronomical theorjes of the thirteenth century were based on the geocentric 
system of Ptolemy. The stars are fixed in concentric spheres whose revolution around the earth accounts for their diurnal motion. But who sets them in motion ? Not astral souls, as Aristotle had taughtintelligent and divine forms, "unchangeable actualizations of the Nature-soul, identical with itself everywhere, yet also everywhere differentiated by the greater or less degree of docility of the body it informs" ; but intelligent motors, as St. Thomas taught, extrinsically related to the spheres which they set in motion mechanically. ${ }^{2}$ To explain the complex motions of the planets various hypotheses were put forward: homocentric cycloids, excentric cycloids and epicycloids. Of the planets, the moon is the nearest to the earth. Hence the term sublunary applied to earthly substances.

79. Whilst the heavenly bodies move in a circle, earthly bodies move in a straight line; and this is indicative of their inferiority. Fire which is "absolutely" light, and air which is light "relatively," move naturally upwards; earth which is absolutely heavy, and water which is relatively so, tend naturally downwards. So that each of the four sublunary elements possesses its own proper place: fire fills the upper regions; earth fills the depths; water and air come between, water next the earth, air next the fire. These, with the ether or fifth essence (quintessence), which constitutes the heavenly bodies, form the whole stock-in-trade of the medieval cosmogony. The ancients inferred the unity of the world from the tendency of each element towards its own natural place; from the property of weight in the heavy elements they inferred the central position of our earth in the universe, its spherical shape and its immobility.

1 Piat, Aristote (Paris, 1903), p. 129.

2 "Ad hoc autem quod moveat, non oportet quod uniatur ei ut forma, sed per contactum virtutis, sicut motor unitur mobili." Summa Theol., I., q. 7a, a. 3. 
The earthly bodies are moreover mutually opposed in regard to their sensible qualities: warm and cold (active qualities), dry and moist (passive qualities). As every body is both active and passive, each element is endowed with a combination of some two qualities taken one from each pair: warm and dry (giving fire), warm and moist (giving air), cold and dry (giving earth), cold and moist (giving water). By reason of such oppositions the elements can be changed into one another: but more especially do they give rise, by chemical combination, to the "mixtum" or chemical compound, which the science of the Middle Ages distinguished perfectly well from the mechanical mixture. The formation and dissolution of "mixta" explain the constant change that is going on in the inorganic and organic kingdoms.

80. This incessant change implies the uninterrupted activity of efficient causes. And as these latter are arranged in hierarchical order, the efficiency of the earthly forces is ultimately traceable to the heat and other active powers of the heavenly bodies: on the abiding continuity of these celestial forces depends the continuity of all terrestrial change. "All multitude," says St. Thomas, " proceeds from unity. Now what is unchangeable or immovable has one sole mode of being; while what is movable can have many. And hence we see that throughout all nature motion comes from something immovable. Hence, too, the more immovable a thing, the more is it a cause of motion. But the heavenly bodies are the most unchangeable of all bodies, for they are subject only to local motion. Therefore the manifold and varied motions of mundane bodies are to be referred to the motions of the heavenly bodies as to their cause." 1 In this view the heavens are

" "Cum omnis multitudo ab unitate procedat, quod autem immobile
est uno modo se habet, quod vero movetur, multiformiter, consider-
andum est in tota natura, quod omnis motus ab immobili procedit.
Et ideo quanto aliqua magis sunt immobilia, tanto magis sunt causa 
made the source of all terrestrial change; they effectuate the union of forms with matter, and are thus the cause of all generation.

This theory explains the exaggerated importance attached to the stars in the later Middle Ages, as well as the vogue of the many arts which professed to study their influence: magic which interrogated the occult powers of the heavens; astrology which explored the ruling influence of the stars over human destinies; alchemy which sought to supplant the ordinary course of terrestrial change in bodies by an artificial method under man's control, and so to direct the mysterious transforming power of the heavens as to make primal matter pass through all sublunary forms. ${ }^{1}$

\section{SeCtion 16.-PSYCHOLOGY.}

81. According to the medieval classification of the sciences psychology is merely a chapter of special physics, although the most important chapter; for man is a microcosm; he is the central figure of the universe. The full development of psychology synchronizes with the culmination of philosophical culture in the thirteenth century. The fragmentary and imperfect treatises of earlier times give place to complete and comprehensive studies, published as separate works on psychology (22). Conformably with the plan usually followed in the Middle Ages, we may divide the problems of scholastic psychology

eorum quæ sunt mobilia.' Corpora autem cælestia sunt inter alia corpora magis immobilia: non enim moventur nisi motu locali. Et ideo motus horum inferiorum corporum, qui sunt varii et multiformes, reducuntur in motum corporis cælestis, sicut in causam." Summa Theol., ra. q. I I 5, a. 3 .

1 The medicine taught at the time was also coloured by the theory of the four elements. These were supposed to be found in the body in the form of humours (bile, spleen, blood, black bile) whose respective predominance accounted for the four temperaments, and whose harmonious blending constituted health. 
into two groups, according as they treat of the nature of man, or of his activities. In the former group we find three leading theories: the soul is the substantial form of the body ; it is spiritual and immortal; it is created by God.

82. Not the soul alone, but the whole man is the object of scholastic psychology. Now, man is a substantial compound, of which the soul is the substantial form, and the body the primal matter. Thus we have the most intimate conceivable relation established between the two constitutive elements of our being; and we have these, relations explained by the general theory of hylemorphism as set forth above $(63,64)$. For example, the soul gives the body its substantial perfection, its actual existence and its life ${ }^{1}$; in the human nature (id quod agit) the soul is the formal principle (id quo agit) of all activities.

This is an Aristotelian theory, and breaks with the earlier medieval theories which were all of a Platonic tendency. The pseudo-Augustinian treatise De Spiritu et Anima, which the twelfth century adopted as its manual of psychology, illustrates the union of body and soul by the comparison of the ship and the pilot, and infers the juxtaposition in man of two substantial beings. Alanus of Lille (1128-1202) was a philosopher who summed up and systematized the intellectual work of four centuries ; and he represents the human soul as an independent substance associated to the body through a sort of connubium or copula maritalis, effected by the agency of a spiritus physicus ${ }^{2}$. Thirty years later these conceptions were supplanted by that of the peripatetic anthropology which gained universal acceptance among scholastics from the time of Alexander of

1 " Anima dicitur esse primum principium vitæ in his quæ apud nos vivunt." St. 'Thomas, Summa Theol., 1a, q. 75, a. 1.

- Baumgartner, Die Philosophie des Alanus de Insulis, Münster, 1896, PP. IO2, and foll. 
Halès. The thirteenth century did indeed accept and hand on the theory of the spiritus physicus, bequeathed to the Middle Ages by Greek antiquity; but it did not follow Alanus of Lille by making this spiritus a third factor acting as connecting link between soul and body; neither did it on the other hand identify the spiritus with the buman soul, like Telesius and the Renaissance naturalists in their materialistic psychology; but it saw in the spiritus an emanation from the informing principle, an agency which disposes the brute matter for the activities of organic life.

If, however, all the great scholastics were agreed in explaining human nature by the hylemorphic theory, each of them was guided by his own metaphysics (64) in deciding whether the spiritual soul, by informing the body, does or does not exclude the presence of other substantial forms, especially that of the "plastic mediator" or forma corporeitatis, in the compound. It was of course on this psychological application of the general question that the respective supporters of the unity and of the plurality of forms carried on their warmest discussions. The Thomist thesis finally prevailed, though the other opinion was never condemned; and, indeed, if we except some extreme and ill-framed formulæ-such as that of Peter Olivi (Petrus Joannis Olivi), for example, ${ }^{1}$ the recognition of a plurality of forms is not regarded as incompatible with the fundamental principles of scholastic psychology and metaphysics.

83. If scholasticism renounced Plato and St. Augustine in its enquiries into the composite nature of the human being, it availed of their assistance in

\footnotetext{
1 Peter's teaching was, moreover, not recognised in his own order. Among those who disowned him was Richard of Middleton, himself a supporter of the plurality of forms. On Olivi and the Council of Vienne, see a series of articles by Père Elirle, in the Archiv. f. Litter. $u$. Kircheng. d. Mittelalters. II. and III. Cf. our Histoire de la philosophie médiévale, Ist edit., p. 304.
} 
establishing the spirituality of the soul. ${ }^{1}$ Those who claimed for human reason the power of demonstrating the spirituality of the human soul-and they were the vast majority among scholastics-appealed by preference to its independence as regards matter in its highest operations. Differing from Aristotle, the scholastics attributed immateriality not merely to the active intellect or any other faculty, but to the very substance of the soul. And since immortality has no other intrinsic reason than the immateriality of our intellectual cognitions and volitions, it is not merely the active intellect in a state of cold and barren isolation (Aristotle) that will survive the body, but the whole soul in the enjoyment of its conscious and personal life, and in the full exercise of all its nobler activities. This new theory, put forth against the erroneous or misleading statements of Aristotle, should of itself suffice to vindicate scholasticism from the charge of undue servility to tradition in the department of psychology.

Duns Scotus, as is well known, threw doubts on the demonstrative force of the arguments brought forward by the Stagyrite in favour of the immateriality of our intellectual life. Those doubts were collected by William of Occam, and subsequently exploited against the scholastic system by the Averroïsts and the philosophers of the Renaissance. But it is well to bear in mind that the attitude of Scotus was purely negative; and that his criticism was moreover not absolute, but merely relative to the Aristotelian argument. Neither Scotus nor Occam ever claimed to have discovered any positive reasons against the spirituality of the soul ; their psychological teachings differ essentially from the materialist views of the fifteenth and sixteenth centuries.

1 "Animam considerando secundum se, consentiemus Platoni; considerando autem secundum formam animationis quam dat corpori, consentiemus Aristoteli." Albert the Great, Summa Theol., II., 348. 
84. St. Augustine's perplexities about the origin of human souls-by generation or by creation-had percolated down to the twelfth century; but from the beginning of the thirteenth we find scholastics unanimous in teaching that the direct and continuous intervention of the Creator can alone bring into existence the human souls destined to animate the bodies of infants. There can be scarcely any need to observe that creationism has nothing in common with the Platonic theory of pre-existence, nor with the nondescript Aristotelian theory which would account for the origin of the human body and of the passive intellect by the laws of natural generation, while attributing an ill-defined extrinsic (ejpatsv) origin to the active intellect.

85. The activities of the soul can be divided into fundamentally different groups. The faculties from which they come can acquire an ever greater facility of action by repeated exercise; and this abiding tendency to act in a given direction is called a habit. As to whether the faculties have a reality distinct from the soul, or are merely different modes of one and the same energy applied to different objects-that depends on the issue of the metaphysical discussions which determine the general relations of the contingent substance to its powers of action (62).

Whichever opinion they espoused on this pointone of secondary importance in psychology - the scholastics classified the vital functions of man into three groups : the lower or vegetative functions, such as nutrition and reproduction; the cognitive functions; and the appetitive functions. The two latter groups occupied most attention, as they include the whole psychic life proper. Then, further, the scholastics were true to their spiritualist principles in distinguishing carefully two irreducible orders of psychic activity, the sensible and the suprasensible; 
so that we must recognise two orders both of knowledge and of appetition.

86. A leading authority on scholastic philosophy, Fr. Kleutgen, S.J., ${ }^{1}$ sums up its teaching on both kinds of knowledge in three general principles, which underlie all the ideological theories of scholasticism on the nature and origin of our mental representations.

Firstly: The known object is in the knowing subject as a mode of being of that subject. "Cognitum est in cognoscente secundum modum cognos"entis."

Secondly: All cognition takes place after the manner of a representative image of the thing known in the knowing subject. "Omnis cognitio fit secundum similitudinem cogniti in cognoscente."

Thirdly: This representation is effected by the co-operation of the known and the knower. And this co-operation guarantees the real objectivity of our knowledge.

87. In sensation, the known object is reproduced (psychically), in the representative act, in all its concrete conditions: it is a material thing existing at a perfectly definite time and place. We see an individual oak-tree, for example: it meets our gaze with its whole retinue of actual properties, and these we attribute to it and to it alone, here and now present at this instant of time and at this point of space. Hence we say that sensation seizes on its objects in all their individual conditions.

And this is so in all sensation. The scholastics, with Aristotle, distinguish the senses into external and internal. The former (hearing, seeing, smell, taste, touch) reveal to us some external object which either some one of them (sensibile proprium), or many together (sensibile commune) perceive. The informations of the internal senses, on the other hand,

${ }^{1}$ Kleutgen, La philosophie scolastique (French trans. from German, Paris, I 868). V. I., pp. 30 , and foll. 
come from within-as the name itself indicates. These are : the common sense, which makes us aware of our external sensations and distinguishes between them; the imagination and the sense memory, which store up the traces of past sensations, recall and combine them (phantasma), and can thus contribute to the production of thought in the absence of an external object; the vis astimativa (instinct) in the animal, or vis cogitativa in man-a power which, blindly in the former, and directed by intelligence in the latter, appreciates the utility or harmfulness of the sense properties of an object.

The seat of sense knowledge is the organism, that is to say, the body "informed" by the soul. The Western medieval philosophers were inclined to emphasize unduly the physiological side of sensation. This was owing to the influence of a twofold current of Arabian thought, coming through Monte Cassino (in the eleventh century), and through the Arabian schools of Spain (in the twelfth) : an influence that led more than one scholastic to conclusions bordering on materialism. But the thirteenth century masters set things to rights : in addition to the physiological, they bring out the psychological aspect of sensation; they proclaim the two phases of the total process to be mutually irreducible; and they assert the interdependence of these phases as a fundamental law not only of sense life but of all perceptive and appetitive activities whatever.

The study of the origin of sensation brings to light the causal co-operation of object and subject. Here the scholastics give proof of their remarkable powers of psychological analysis. A representative faculty is described as passive $;^{1}$ that is to say, in order to

1 A technical expression, often misunderstood. Froschammer, for example, a recent biographer of St. Thomas, failing to grasp its meaning, accuses the latter of making knowledge a purely passive phenomenon. Same error in Erdmann, Geschichte der Philosophie, I., p. 452 (Berlin, 1892); in Werner, Joannes Duns Scotus (Vienna, 
pass into a state of action and to produce that immanent perfection commonly called "knowing," it must receive from some external source or agency a something to determine and complete it in its very being. This stimulation by the external object is in the nature of an initial impulse, without which the senses should remain in a state of perpetual inaction. When the disturbance from without reaches the passive faculty, the latter reacts, and this reaction completes the cognitive process. Impressed and expressed species or image species impressa, expressa), or, to vary the phrase, representation impressed from without and revealed or shown forth from within-are the terms most commonly used to describe this double aspect of the one single phenomenon which is accomplished wholly and entirely within us.

It is of interest to note, in this connection, the growth of a physical theory from this psychological teaching-the theory of the medium. The science of the thirteenth century would have the external object act upon the sense organ not by direct contact but through an intermediary. In the process of vision, for example, the object influences the air, and produces the psychic determination through its agency. But whether the external agent that immediately excites the cognitive faculty be the object itself, or some second factor of the physical order, the diffieulty remains all the same: in the one case as in the other a material agent contributes to the production of a psychic phenomenon, and the mystery is there still.

All the leading scholastics-St. Thomas and Duns

I 88 I), p. 76 . A passive faculty is not a non-acting faculty, but simply one which is passive before being operative, which must be determined or " informed" by something other than itself before exercising an activity; in opposition to an active power which has no such need of any outside influence, and which passes into action as soon as the requisite conditions are present. 
Scotus, to mention no others-had a full appreciation of this difficulty, for they draw a sharp and clear distinction between the psychic immutatio wrought by the object in the sense, and the physical phenomena which take place in the medium. We must regret the fact, however, that the exact bearing of their analysis in this matter was not fully grasped by many of their contemporaries; not a few of the latter were led astray by the distorted interpretation of the "species sensibilis" to be found in so many of Aristotle's commentators. For these the "species" was not a determinant of the psychic order, an action excited by the object and elicited and terminated in the faculty; it was rather a miniature of the external thing, a tiny image that traversed the intervening space and entered the organ, a sort of substitute for the reality, a proxy that established contact 'with the sense, was assimilated by the latter, and thus provoked conscious knowledge : an absurd conception entertained by certain Aristotelians of the time of William of Auvergne, and to which we shall have occasion to recur.

88. On the object of the human intellect and its essential difference from the sense faculties, the teaching of scholasticism is peripatetic. While sense knowledge attains only to the particular and contingent (87), the intellect reaches realities whether substantial or accidental, by stripping them of the individualizing features that characterize the objects of sense. That is to say, the concept is abstract, and accordingly its object, looked at by the intellect, can be universalized or referred to an indefinite multitude of individual things. Our eyes see this oak, this colour; our intellect conceives oak, colour, tree, being in general.

According to St. Thomas, our cognitions are abstract not only when they regard the world of sense, which is the proper object of our intellects, 
bus even when they have for object the nature of the soul. The existence of the ego is the only intuitive datum we have: this is given in every single conscious activity of ours, according to the expression of St. Augustine: ipsa (anima) est memoria sui.

But if the understanding conceives only the abstract and universal aspects of things, must we therefore deny it all direct knowledge of the individual? St. Thomas thinks we must, and his conclusion is logical. And to meet the objections which at once arise, he grants the intellect a certain sort of knowledge of individual things, a knowledge got by a kind of reflexio or applicatio whose nature is one of the obscure points of Thomism. In their anxiety to leave to the human intellect an immediate perception of the individual, the Angelic Doctor's rivals would not follow him in these bold deductions : they preferred to introduce into their complicated psychologies a lot of new apparatus, not easy to explain or to justify. Duns Scotus, for example, and William of Occam, not content with the abstract and universal representation, which, they say, results from distinct knowledge, recognise in addition an intuitive knowledge which vaguely reveals to us the concrete and individual existence of things. But it may well be asked in what does this intuitive intellectual knowledge differ from sense perception; and whether the distinction does not regard the degree of clearness rather than the nature of the mental process.

We see then that abstraction remains the keystone of scholastic ideology. It supplies us, moreover, with the final solution of the criteriological problem, and of the time-honoured enigma of the universals. We have already referred to the metaphysical aspect of the question, and to the "three states of the essence." There is a second formula which bears more directly on the psychology of the 
problem : The essence may be submitted to a threefold subjective consideration, "secundum esse in natura, secundum se, secundum esse in intellectu." Secundum esse in natura, it is individual; secundum $s e$, it is simply the essence of things, abstracting from their mental or extramental existence; secundum esse in intellectu, it is universalized, conceived in relation with an indefinite multitude of things of the same species. The process of universalization, as such, is subjective; it is superadded to a previous process of abstractive segregation, which grasps the objective being of things.

89. How are those abstract and universal representations formed in our minds? This was another favourite subject of research in the thirteenth century. A well-known adage sums up the results: Nihil est in intellectu quod prius non fuerit in sensu. This formula asserts the sensible origin of all our ideas, and the dependence of our highest intellectual operations on the organism. The intelligible object must somehow affect or determine the "passive faculty of the understanding." This is obviously essential for the genesis of all intellectual thought. And to bring about this determination, two things are absolutely necessary: the presence of a sensible image of some sort (phantasma), and the operation of a special abstractive faculty (intellectus agens). Nor are the scholastics less unanimous in maintaining, against the Arabian philosophers, that all those various thought-principles are within the soul, and that the hypothesis of an external or "separate" active intellect cannot be reasonably entertained. When, however, they approach the study of those principles more closely, and try to determine the part played by each factor in the total process-by the active intellect, the passive intellect and the phantasm, respectively-they espouse different and conflicting opinions. 
The question is a delicate one: on the one hand, the understanding is like a virgin page on which the outside world is somehow to be traced; on the other, it would seem that there is nothing fit to actuate this understanding, since its proper object, the abstract and universal, does not exist as such in nature (65). According to St. Thomas and Duns Scotus, it is the sensible reality that acts on the passive intellect, by means of the phantasma, but this latter can exert a merely instrumental causality under the efficient influence of an immaterial faculty, the active or acting intellect (intellectus agens). Under the influence of this higher power, the sensible image, or in ultimate analysis the external object itself, sets the passive intellect in action (species intelligibilis impressa) : this action, which is immanent and representative in character, completes the intellectual process of abstract cognition (species intelligibilis expressa). Here, as in the study of sense knowledge, we see the theory of the psychic determinant supplementing the simple notion of a passive power.

The "terminists" or "Occamites" of the fourteenth and fifteenth centuries, and at a later period, Malebranche, Arnauld, Reid and others, tried to throw ridicule on the doctrine of the species intelligibiles, regarding them as a purely fanciful apparatus uselessly introduced into the process of ideation. But curiously enough, all their polemics arise out of a misunderstanding of the doctrine. As a matter of fact, immediately after the introduction of the new text of Aristotle into the West, a false interpretation of the species intelligibilis became current-an error analogous to that already referred to in connection with the species sensibilis. William of Auvergne (d. 1249), Bishop of Paris, one of the most renowned philosophers and theologians of his time, informs us that several of his contemporaries defended the 
theory of the spiritualized phantasm, or of the transformation of the species sensibilis into a species intelligibilis, under the purifying influence of the intellectus agens. ${ }^{1}$ Here the species intelligibilis plays the same role in the understanding as the species sensibilis, for it is a simple prolongation of the latter: a substitute for the external world, which comes before the faculty as before a photographic camera, acts upon it and thus enables it to know the external thing of which the species is a mere image. This is not the place to examine critically such an untenable hypothesis ; but we may remark that the supposed transformation of a material effect (the sense image) into an immaterial one (the spiritualized image), uproots the very foundations of scholastic spiritualism. ${ }^{2}$

It would be interesting to know who were those contemporaries of William of Auvergne who had the complete text of the De Anima in their hands, and still supported the false view of the species intentionalis bequeathed to them by the Arabian commentators of Aristotle. Their mistake was widespread in the Middle Ages. William, in refusing to accept it, gives proof of his exceptional grasp of the ideological problem. And when, later on, we find William of Occam urging difficulties against the doctrine of the vicarious species, we cannot blame him for it. But his objections do not touch the genuine doctrine on the species intentionalis. And the best proof of this is that he himself admits a determination of the intelligence from without, and conceives the genesis of our representative states in practically the same way at St. Thomas and Duns Scotus.

${ }^{1} \mathrm{Cf}$. Baumgartner, Die Erkenntnisslehre des Wilhelm von Auvergne (Münster, I893), pp. 49 and 67.

" Malebranche expresses himself as follows: "Those impressed species, being material and sensible, are rendered intelligible by the intellectus agens. The species thus spiritualized are termed expressed." De la recherche de la vérité, L. III., ch. 2. Cf. our article : De speciebus intentionalibus dissertatio historico-critica (Divus Thomas, Plaisance, I897). 
90. The appetitive life is regulated by the universal law : Nihil volitum nisi procognitum. All desire or appetite pre-supposes a knowledge of the thing desired. The sense appetite is the inclination or tendency of the organism towards a concrete object presented by the senses as an individual good. The intensity of this inclination is the source of the sense passions: and these furnish a fertile field for commentaries and classifieations, wherein the scholastic genius finds free scope.

The rational appetite or will is moved to action by the presentation of good in the abstract. Here, likewise, the mainspring of the appetitive inclination is the perfecting or developing of the appetitive subject or being: Bomum est quod ommia appeturt. According to St. Thomas, the action of the will is necessary when the latter is placed in presence of the absolute good, for this fully and completely satisfies the appetitive faculty ; it is, however, free when the good presented is contingent, and accordingly insufficient to satisfy fully the will's capacity for enjoyment. But even this free choice of a particular good presupposes the irresistible straining of the rational appetite after the good in general.

Henry of Ghent, Duns Scotus and William of Occam take a somewhat different view of liberty and of our manner of exercising volitional activity, from that of St. Thomas. They look upon liberty as the primordial and essential attribute of volition, and ascribe to the will an absolute power of self-determination; the spontaneity of the act involves its liberty. In none of its volitions is the will necessitated by the good presented by the intellect: even in presence of the universal good the will preserves its freedom both of exercise and of specification, for, says Scotus, it has the power of turning aside from the intellectual presentation. This absolute indeterminism of the will reveals the mode of action 
of the latter faculty: the appreciation of the value of a given good by the intellectual faculty, is merely a conditio sine qua non, but never exercises any causal influence proper on volition. ${ }^{1}$ While St. Thomas regards the will as a passive faculty in the technical sense of the word, Scotus and Occam hold it to be purely active like the intellectus agens.

Emphasizing those divergences between medieval intellectualism and voluntarism, many modern historians have professed to find a proclamation of the primacy of the theoretical reason in the Thomist theory, and in the Scotist and Occamist theories an affirmation of the primacy of the will. ${ }^{2}$ And they refer, in support of their view, to the numerous articles in which the medieval doctors examine the various relations of co-ordination and subordination between the intellectual and volitional activities in order to decide for the superiority of either one of these faculties over the other.

But since the time of Kant, the primacy of one faculty over another is to be understood in a very special sense, and imparts to a system of philosophy a definite criteriological colouring, so to speak, a well and clearly marked attitude. ${ }^{3}$ It is a formula which may not be transported into medieval philosophy without changing its meaning. For those scholastic discussions on the primacy of the spiritual faculties were of very minor importance : the scholastics never dreamed of a " dogmatism of the practical

[ ${ }^{1}$ See, however, an important study on this subject by Dr. Minges, O.F.M., Ist Duns Scotus Indeterminist? (Beiträge zur Geschichte der Philosaphie des Mittelalters, Band V., Heft 4; Munster, I905), in which the Subtle Doctor is defended against the charge of having taught the absolute indeterminism of the will. Cf. also, review of same work in the Philosophisches Yahrbuch, B. I9 (1906), H. 4, pp. 502-506.-Tr.]

"Among others, Windelband, Geschichte der Philosophie (1892). p. 259.

${ }^{3}$ Kant propounds the primacy of the will or practical reason over the pure or theoretical reason because the former reveals to us the existence of noumenal realities (liberty, immortality and God), which are beyond the reach of the theoretical reason and its certitude. 
reason," nor of the encroachment of volition upon knowledge. Even among the medieval voluntarists, the adage nihil volitum nisi procognitum is fully recognised. As Henry of Ghent expresses it, the hierarchical relations of the will and the reason are analogous to those of master and servant, but it is none the less true that the servant goes before his master and bears the torch to light him on his way.'

\section{SECTION 17. - MORAL PHILOSOPHY AND LOGIC.}

9]. The scholastics of the thirtecnth century approached the philosophical side of moral questions : previously these had been studied mainly from the theological point of view. A system of moral philosophy essentially implies a theory on the end of man and on the human act. It is, in fact, the study of human acts or conduct (material object) in their relation to man's last end or destiny (formal object). The human act par excellence is the free act: this alone is moral or immoral. The last end of man is God: to possess Him is the object of the natural tendencies of all our highest psychical activities. Aristotle knew little or nothing about the natural happiness of man. The scholastics on the contrary have proved that knowledge (visio) and love (delectatio) of the Creator constitute the most perfect activity of which man is capable: that the actual securing and enjoying of beatitude, as such, is accomplished by an act of knowledge (St. Thomas) or of love (Duns Scotus) or of both combined (St. Bonaventure). Accordingly, the free act which tends towards the possession of God will be moral, or morally good; that which draws us away from Him, immoral, or morally evil.

On moral obligation the scholastics propounded a

1 Henry of Ghent, Quodl., I., I 4, in fine. 
theory unknown in Greek philosophy. Moral obligation has its foundation, as St. Thomas teaches, in the very nature of our acts ; for this nature serves as basis for the lex naturalis with which our consciences are impregnated, and from which all positive law derives its binding force. But ultimately it is to the divine order we must look for the binding force of all law.

Since human nature is morally bound to tend towards its own good, it is likewise bound to utilize the means that are necessary for this purpose. We are led into the knowledge of these means by that habitus principiorum rationis practicae which the scholastics called synderesis. Under the guidance of this synderesis the intellect formulates the general regulative principles of the moral life; while moral conscience is merely the application of these universal principles to some particular case.

It is interesting to remark that the constitutive elements of the moral goodness of an act (object, circumstances and end), those in virtue of which it tends towards its proper end, are identically the principles of the ontological perfection of the act. The degree of ontological or real perfection in an act is likewise the measure of its morality: a further example of the consistency and solidarity of the great leading ideas of scholasticism.

92. The scholastics addressed themselves again, after the example of Aristotle, to a detailed study of the moral virtues, analyzing exhaustively the various grooves into which our moral activity runs in the varying circumstances of life. Their teaching on the nature of morality in general is followed by a body of doctrine dealing with the several relations, domestic, religious and civil, which specify our moral activities in the concrete.

Private property and monogamous and indissoluble marriage are dictated by the natural law. Social 
life has its raison d'être in human nature itself. and ultimately in the will of God. For all authority is of divine origin. St. Thomas does not seem to have troubled about the origin of authority in a society a)ming newly into being. But he does discuss the various forms of government in an existing state: and he declares them all to be legitimate so long as those in power govern with a view to the common good. After the manner of the ancients, especially of Plutarch, the different classes of society are compared to the various members of a living body, but nobody ever thought of ascribing to this analogy the real significance attributed to it by certain organicists in our own time. We also find in the social ethics of the Middle Ages some traces of the communal and feudal organizations of society. ${ }^{1}$ Finally, the thirteenth century justifies the subordination of the temporal to the spiritual power; but already in the fourteenth we find certain writers influenced by the hostile spirit that animated the princes of the time against the papacy.

93. Aristotle is the undisputed master of logic, and the scholastics merely comment on his teaching. Logic is understood to be the body of laws to which the mind must conform in order to acquire science. But what are we to understand by science? It is knowing what a thing is, in a necessary and universal manner. Scientia est universalium. It is not concerned with the individual, particularizing characteristics of things. $\mathrm{By}$ scientific demonstration, and syllogism which is its basis, we discover the essences, properties and causes of things. Hence the importance attached by Aristotle to those processes: they form the chief subject-matter of the Analytics, bis principal logical treatise. But the investigation of both processes implies the preparatory study of

${ }^{1}$ See on this subject Max Maurenbrecher, Thomas ion Aquino's Stellung zum Wirthschaftslelien sciner Zicit. I. Heft (Leipzig, 1898). 
the simpler operations into which they may be resolved, namely, conception and judgment.

The concept represents things to us under abstract and general aspects, some proper to a single species of things, others common to the several species of a common genus. Logic deals with the concept only in so far as it is an element of the judgment. And accordingly, when the scholastics transport into logic the categories of being, they take the latter not in the sense of classes of existing realities but of objective concepts capable of standing as predicate or subject in a judgment.

Judgment or enunciation is the union of two concepts, of which one (the predicate) is affirmed or denied of the other (the subject). The $D e$ Interpretatione studies the quality of judgments (affirmation, negation), their quantity (universality, particularity), and their modality (necessity, possibility, contingency).

It is the syllogism that almost monopolizes the attention of medieval logicians. They study at great length this process by which the human mind, while not perceiving immediately the relation between two concepts, the possible terms of a judgment, compares them successively with a third or middle term. The demonstrative syllogism, which alone leads to scientific knowledge, arranges our ideas by deducing the particular from the general; it coordinates and subordinates our mental notions according to their degree of universality. But demonstration has its limits, for the mind must stop at some indemonstrable first principles which it sees to be self-evident as soon as it has abstracted them from the data of sense. In like manner, definition (iprouós) and division must reach a limit, for it is impossible to define everything, or to analyze things ad infinitum.

Those sciences are deductive or rational which 
can be built up independently of experience, by the simple drawing out of the objective relations between our concepts : the mathematical sciences, for example. The inductive or experimental sciences are those that offer us an explanation of the facts of sense experience. The nature of the science will determine the sort of method to which it ought to have recourse (14).

94. In the general economy of the scholastic system, logic is regarded as merely an instrument of knowledge, but it is very closely allied to metaphysies and psychology. Nlbert the Great and his successors laid down clearly the relations of the science of concepts to the science of reality. For St. Thomas's master, logic is a scientia specialis, the vestibulum of philosophy: preliminary to the latter as drawing is to painting. Thus the golden age of scholasticism put an end to the absurd and ruinous despotism exercised by dialecties in the early Middle Ages. Towards the end of the twelfth century we find in the poetic language of Alanus of Lille the comparison of logic to a pale maiden, emaciated and exhausted by too protracted vigils.

Unfortunately those excessive subtleties of the logicians were destined to reappear (96). But this was when scholasticism had begun to degenerate; and such decays and failings as that to which we must presently call attention, cannot in any way detract from the real value of the great doctrinal synthesis we have been trying to outline.

\section{SECTION 18.-CONCLUSION.}

95. After the sketches we have just given, let us recall for a moment the question raised above: in what should a real and intrinsic definition of scholasticism consist? (7) It should be derived from within, and should give the fundamental doctrines 
of the system itself. Now to get at these essential features we need only to take up in detail the solutions it offers, and to study the distinctive marks of these latter. Each mark will differentiate and individualize scholasticism in some special way; and the whole collection of them will portray the essential nature of scholasticism $(57,58)$. Any one of these signs taken by itself may possibly be common to scholastic.. ism and some other historical solutions; but the sum-total of them taken together will be found in scholasticism and in it alone. ${ }^{1}$

The chief of those great leading features of scholas. ticism might be indicated as follows: In the first place scholasticism is not a monistic system. The dualism of the purely actual being of the Divinity on the one hand, and creatures composed of act and power on the other, erects an impassable barrier against all pantheism. Moreover, the compositions of matter and form, of individual and universal; the real distinctions between the knowing subject and the known object, between the substance of the soul in heaven and the substance of God who fills and satisfies its faculties : those are all doctrines manifestly incompatible with monism. Scholastic theodicy is creationist and personalist. The scholasicic metaphysic of the contingent being is at once a moderate dynamism (act and power, matter and form,

${ }^{1}$ A point lost sight of by M. Laplasas in his criticism of our view. This author's pamphlet (Ensayo de una Definicion de la Escolastica, Barcelona, 1903) reviews an article published by us in the Revue philosophique (June, 1902), and shows a grave want of acquaintance with scholastic teaching. Further, we believe M. Blanc to be wrong in thinking that the scholasticism common to St. Bonaventure, Scotus, Suarez and others, " is in no way distinct from any other Christian philosophy whatever, from Caro's, for example, or even from Cousin's in the later editions of Le Vraï, le Beau et le Bien." (Université cathol., I90I, p. II4). Not to mention the fact that several theories of this "common scholasticism "-its ideology, for example-will ever remain irreconcilable with the corresponding theories of a Caro or a Cousin, the whole collection of the doctrinal characters of scholasticism belongs to it alone, and the accidental agreement of scholasticism and French eclecticism in occasional, isolated conclusions cannot destroy the specific oneness of the medieval system. 
essence and existence) and a frank avowal of $i$ dividualism. This same dynamism governs the formation and dissolution of natural substances: while from another standpoint the material world is interpreted by scholasticism in an evolutionist and finalist sense. Then, again, scholastic psychology is not materialist but spiritualist, not idealist or a priori but experimental, not subjectivist but objectivist : its very definition of philosophy implies that the intellect is capable of seizing an extramental reality. Its logic, based on the data of psychology and metaphysies, advocates the use of the analyticosynthetic method. Its ethical teaching derives its principal features from psychology : it is eudemonist and libertarian.

By varying our standpoint and examining the scholastic system in other ways we might find other intrinsic features for our definition. An integral definition would embrace them all. They are all connected with one another, and they all complete one another: and so they ought, for the different doctrinal departments defined by them are bound closely together in a compact organic unity. 


\section{CHAPTER III.}

\section{THE DECLINE OF SCHOLASTICISM.}

Section 19. - general causes of the DeCadence OF SCHOLASTICISM TOWARDS THE CLOSE OF THE MIDDLE AGES.

96. Very much still remains to be written about the decline of scholasticism from the commencement of the fifteenth century-about the causes of the decay, its different stages and its general significance. Valuable data for such a work have been already collected; and these point to the conclusion that the decline in question must not be regarded as the death-agony of a philosophical system killed by modern discoveries, but rather as a very complex intellectual movement laden with many injurious influences quite other than the philosophical doctrine itself. An impartial study of these factors would go to show that the sterility of the period in question is to be laid at the door of the philosophers rather than of the philosopby. This is the first important reserve we are forced to make when we hear and read of the "end of scholasticism," and of its annihilation by modern ideas. And we shall try to justify this contention in the pages that follow.

Yet another reserve, of a different kind, may be merely mentioned here; the works of specialists would need to be quoted in justification of it. It is this: Notwithstanding the general bankruptcy of 
scholasticism in the West, there was a real and profound revival in Spain and Portugal during the sixteenth century, a return to the great, leading principles of scholasticism, an intellectual awakening which bears eloquent testimony to the vitality of its doctrines in the hands of really capable men as distinct from petty, unenlightened quibblers. In the midst of the barren wastes this branch was seen to blossom forth and to bear abundani fruit. There were certain extrinsic causes, however, which militated against the new scholasticism of such men as Suarez and Vasquez. Horeover, its failure to adapt itself to contemporary forms of thought accounts quite sufficiently for the ephemeral character of its influence. At the same time it must not be forgotten that the tradition of scholastieism was never entirely interrupted even down through the seventeenth and eighteenth centuries and up to the commencement of the neo-scholastic revival that will be dealt with in the second part of the present volume. Ever and anon we see great names arise above the level of an almost universal mediocrity, to form occasional brilliant links in the long rhain that connects the sixteenth with the twentieth century.

97. Amongst the reproaches heaped upon the dethroned sovereign by the philosophers of the Renaissance and their successors, were, first of all, her linguistic barbarisms and her barren and obsolete methods. The Latin of the fifteenth century and subsequent scholasticism shows a lamentable distegard for even moderate accuracy: and the humanists, in their well nigh idolatrous cult of literary elegance and style, laid this intolerable and most grievous fault at the door of the philosophy itself. The prevalent contempt for literary form had certainly been disgraceful : it extended even to ignorance of ordinary orthography. It was in vain that a few of the most enlightened members of the University of Paris- 
Peter D'Ailly and John Gerson-protested and pleaded for reform: the Philistine current was too strong to be arrested in its rapid rush to destruction ! Then, too, there were vexatious and inexcusable faults of method: the endless multiplication of distinctions and sub-distinctions and divisions and classifications, on the plea of clearness ; until finally all thought became mystified and muddled in an inextricable maze of schemes, systems and departments! Nothing could have been better calculated to foment those abuses than the dialectio formalism that poisoned all the philosophical writings of the sixteenth century. This excessive hair-splitting tendency, already latent in the terminism of William of Occam (in the fourteenth century), admitted into logic, under the guise of purely subjective notions, a multitude of theories that had been ousted from the domain of metaphysics. And these proved a damnosa hereditas, introducing still further confusion into the already tangled discussions of the logicians.

98. Another and more fatal influence at work was the widely prevalent ignorance of the real meaning and character of the scholastic system. They still, no doubt, talked and wrote of matter and form in the scholastic manuals of the seventeenth century, but they commonly compared the union of those two principles with that of a man and woman who would meet and marry, and then get divorced in order to contract other matrimonial alliances.

When Malebranche and Arnauld ridiculed the "species intentionales", their scoffs and sarcasms were justified by the fantastic notions of those scholastics who had inherited only a deformed caricature of the ideology of the thirteenth century (89).

When Molière concocted his quodlibets against the theory of faculties, or made fun of the "virtus dormitiva" of opium, his bantering sallies were not 
undeserved; for many of his contemporaries who stood by those scholastic formulie, either gave them a merely verbal meaning or mistook their real meaning, betraying equally in both cases the sane and rational metaphysics of the thirteenth century which they thought they were defending.

Add to all this that the leading spirits of the time had, for the most part, lost the habit of thinking for themselves: so much so that their works have been justly described as "commentaries on commentaries." We can easily understand, therefore, that the scholastic manuals and compilations of the later Viddle Ages are no better than mere counterfeits of the masterly productions of the philosophic thought of the thirteenth century.

99. Nowhere was the culpable ignorance of the scholastics regarding contemporary thought so disastrous as in the domain of the natural sciences. Great discoveries were everywhere revolutionizing physical and mechanical astronomy, physics, chemistry and biology,-and the mathematical sciences as well. The geocentric system of Ptolemy gave place to the heliocentric system of Copernicus; and Galileo's telescope had begum to reveal the secrets of the heavens. But the paths of the stars careering through the immensities of space gave the theory of solid celestial spheres its death blow : the displacement of the sun-spots on the solar disc revealed a rotatory motion in the sun itself: the moon displayed its mountains and plains. Jupiter its satellites, Yenus its phases, Saturn its ring. In 1604, a hitherto unknown star was discovered in the sign of the Scorpion. Later on it was shown to evidence that the magnificent comet of 1618 was not an atmospheric will-o'the-wisp but a heavenly body moving through the interplanetary regions of space. Then Kepler formulated the laws of the elliptical motion of the planets, and Newton inferred from Kepler's laws the 
law of universal gravitation which unified all astronomical phenomena. In another department, Torricelli invented the barometer and discovered the weight of the air ; heat and cold were registered by the thermometer not as distinct and contrary properties but as different degrees of one and the same property of matter; light was decomposed and water analyzed; Lavoisier laid the first foundations of modern chemistry. At the same time Descartes, Newton, Leibnitz and others devoted their genius to mathematical researches; and, enriched by their contributions, those sciences made rapid and giant strides.

Man's scientific conception of the universe was reconstructed on altogether new lines, and many of the scientific theories which the medieval mind had incorporated in its synthetic view of the world were now finally and completely discredited. To mention only a few: There was an end of the idea that circular motion is the most perfect, and of the theory that the heavenly bodies are exempt from generation and corruption. If there are spots on the sun, the immutability of the heavenly bodies becomes a respectable myth. Nor were the new mechanics long about exploding the theory of the locus naturalis of bodies (15). In short, there was much that needed to be reconstructed or modified.

Now, the traditional astronomical, physical and chemical theories were bound up with the principles of general metaphysics and cosmology by ties that were centuries old-though often indeed of a frail and fanciful character. Were not the principles dependent upon the theories, and did not the overthrow of the ancient science involve the ruin of the ancient philosophy? Not necessarily ; and that for this reason: amid the debris of the demolished science there remained untouched quite sufficient data to support the constitutional doctrines of scholasticism. 
It is sufficiently obvious that philosophers and scientists alike should have closely watched and studied the scientific progress of the time in order to be able to pronounce upon the possibility or impossibility of adapting the new discoveries to the traditional philosophy. That is certainly what the princes of scholasticism would have done had they lived at such a critical turning point in the history of the sciences. We are aware from well-known and oft-quoted texts that they never meant to give all the scientific theories of their own time the value of established theses. but rather of more or less probable hypotheses whose disproof and rejection would in nowise compromise their metaphysies. So, for example, st. Thomas, when, speaking of the movements of the planets, he makes use of these significant words: "Licet enim talibus suppositionibus factis apparentia salvarentur, non tamen oportet dicere has suppositiones esse veras, quia forte secundum aliquem alium modum, nondum ab hominibus comprehensum. apparentia circa stellas salvantur." And his disciple, Giles of Lessines, gives frequent expression to the same view.

But, unfortunately, the reverse of all this was what actually took place. The deplorable attitude of the seventeenth century peripatetics towards the science of their day was just the opposite of what it ought to have been. Far from courting or welcoming a possible alliance between their cherished philosophy and the new scientific discoveries they turned away in terror from the current theories lest they should be compelled to abandon their own out-of-date science. It is said that Melanchton and Cremonini refused to look at the heavens through a telescope. And Galileo speaks of those Aristotelians who, "rather than alter Aristotle's heavens in any particular, obstinately deny the reality of what is visible

${ }^{1}$ In Lib. II. De Coelo et Mundo, 1. xvii. 
in the actual heavens." The Aristotelian teaching they regarded as a sort of monument from which not a single stone could be extracted without upturning the whole. This it is that explains the obstinacy with which they tried to defend the discredited astronomy and physics of the thirteenth century, and the ridiculous attitude of the "Aristotelians" in their widespread university controversies with the Cartesians. ${ }^{1} \quad$ Those philosophers were shortsighted; they were apparently unable to distinguish the essential from the accessory; they failed to realize the possibility of abandoning certain arbitrary applications of metaphysics in the domain of the sciences without abandoning the metaphysic itself.

Is it any wonder that they drew upon themselves the ridicule of the scientists? And these latter in turn made the scholastic philosophy responsible for the errors of medieval science, from which the former had been declared inseparable. When we remember that for very many scholasticism meant merely the old systems of astronomy and physics we can understand at least to some extent why they should treat it with such sarcasm. They were not long about discrediting a system that defended such mistaken views. The necessity of making a clean sweep of the past became more and more apparent. And some, not satisfied with condemning all scholasticism en bloc, went even so far as to condemn all philosophy. It is from this epoch of unparalleled progress in the sciences of observation that we may date not only the sharp distinction between common and scientific knowledge but also the divorce of the latter from philosophy. The more moderate among the scientists, while repudiating scholasticism with scorn,

${ }^{1}$ See an article of Feret, L'aristotélisme et le cartésianisme dans l'Universite de Paris au XVIIe. siècle (Annales philos. chrét., April, 1903), and the interesting work of Mgr. Monchamp, Galilée et la Belgique. Essai historique sur les vicissitudes du système de Copernic en Belgique (Brussels, I 892). 
gave their adherence to some system or other of modern philosophy; for the latter had always professed its respect from the very commencement for the sensational scientific discoveries of the seventeenth century.

To sum up: The contest that arose in the seventeenth century between the peripatetics and the scientists had no real bearing on the essential content of the scholastic teaching, but regarded mere side issues and secondary matters. The misunderstanding was indeed inevitable: it was almost if not altogether irremediable, and unfortunately it exists even still.' The scholastics and the scientists of those days were both alike responsible for it: the latter would cut down the powerful oak-tree of centuries on the pretext that it bore some rotten timber under its spreading foliage; while the former stupidly contended that its hoary head must not be touched at any cost-that by stripping it of a few withered branches it would be deprived of its very life.

100. Francis Bacon reproached the scholastics of his time with ignorance of the sciences and neglect of history; and he was justified in doing so. "Hoc genus doctrinæe minus sanæ et seipsum corrumpentis invaluit apud multos præcipue ex Scholasticis, qui summo otio abundantes, atque ingenio acres, lectione autem impares, quippe quorum mentes conclusa essent in paucorum auctorum, præcipue Aristotelis dictatoris sui scriptis, non minus quam corpora ipsorum in conobiorum cellis, historiam vero et natura et temporis maxima ex parte ignorantes, ex non magno materia stamine, sed maxima spiritus, quasi radii, agitatione operosissimas telas, quæ in libris eorum extant confecerunt." 2

${ }^{1}$ According to M. Deussen, Galileo and Copernicus destroyed not only the old astronomy, but also, without knowing or wishing it, the personal God of the scholastics. Jacob Boehme (p. 20).

"Quoted by Brucker, Historia crit, Philos., vol. III., pp. 877, 878. 
The new philosophical syntheses, elaborated independently of scholasticism and built upon Baconian empiricism or on Cartesian rationalism, soon directed their attacks against one another. The scholastics no longer counted for a force to be reckoned with. Indeed, apart from the value of their doctrines, what general social influence could these men hope to wield who closed their doors and windows against the outside world, and philosophized without the least heed or concern for the dominant ideas of their time?

101. The story of the decline of scholasticism would seem to point to a conclusion of considerable importance for all who have any interest in the new scholasticism of the nineteenth and twentieth centuries: the corrosive action of the causes that encompassed the ruin of medieval scholasticism did not attack its great organic doctrines ; so that its vital parts are still sound and healthy.

Neither barbarisms of language, nor abuses of method, nor faults of dialectic, disprove the substantial soundness of a philosophical system. Nor can the ignorance of those who make a clumsy defence of it in any way lessen its intrinsic value. And if the savants of the sixteenth century neglected to compare scholasticism with the rival philosophies that surrounded it on all sides, scholasticism is not entirely to blame for that negligence, nor can such omission raise any prejudice against the possible issue of a comparison which anyone is at liberty to institute at any time. Exactly the same holds true of the attitude of scholasticism at the present day towards the modern sciences: the question of their compatibility with medieval scholasticism is still an open question, for it has never yet been seriously investigated.

We were justified, therefore, in saying that scholasticism lapsed not for want of ideas but for want of 
men, and that the fact of its decay should in no way militate against an attempt at its revival. But if such an effort is to prove successful we must avoid what was formerly so fatal to its progress ; and thus, once more, we will allow the past to dictate its great and salutary lessons to the future. 


\section{PART II.}

MODERN SCHOLASTIC PHILOSOPHY. 



\section{CHAPTER I.}

\section{SOME EXTRA-DOCTRINAL NOTIONS OF THE NEW SCHOLASTICISM.}

\section{SECTION 20.-THE WORD AND THE THING.}

102. During the last half century many a philosophical system of ancient or of modern date has had both its matter and its form dressed up and refurbished, to suit the changed and changing mentality of the age we live in. "We find that convenient prefix, the serviceable "neo," attached to all sorts of titles in contemporary terminology; and no one dreams of protesting against such descriptive epithets as Neo-Cartesianism, Neo-Spinozism, Neo-Hegelianism Neo-Kantism, Neo-criticism, Neo-idealism, etc. Quite indifferent to the master it serves, the particle sometimes even does duty for sufficiently far-fetched and fanciful doctrines-such as that of Neo-Socratism to quote only one example. ${ }^{2}$ Indeed the pleasure of creating a neologism would seem to have been the only excuse for inventing certain systems devoid of any great positive value or significance.

Why is it then, we may ask, that the term neoscholastic is regarded with such suspicion and hostility,

1 Cf. L. Stein, Der Neo-Idealismus unserer Tage (Archiv. f. system. Philos., I903, pp. 265, and foll.)

${ }^{2} \mathrm{Cf}$. H. Gomperez, Grundlegung der neusokratischen Philosophie (Leipzig, 1897). The author informs us in the introduction that "the Socratic school . . . founded by Leo Haas in 1890 ... is a community of believers who make it their profession of faith that for a man of goodwill there is no evil whether in life or in death." 
although it is even " making its way out of the purely specialist reviews into books, periodicals and the ordinary currency of the Press." It is simply because this new word, having been adopted as a rallying cry by the few, still remains a bugbear in the eyes of the many.

In the first place, it is a scandal to all those who still entertain the old stock prejudices against medieval scholasticism, and who seem to take it for granted that a prejudice must be well-founded simply because it can boast of a hoary antiquity. A name that recalls so many unpleasint old charges and controversies naturally excites repugnance and distrust: the revival of a past so thickly strewn with errors would seem to be of necessity a retrograde step; it would be the rehabilitation of a narrowly clerical thought-system, manacled by the restraints of the Roman Church; it would oppose the modern spirit and ignore the scientific discoveries and methods of which our.century is so justly proud.

Secondly, the word is a stumbling-block to those exclusive admirers of the past who would fain amass all the best traditions of the Middle Ages and transmit that sacred deposit to posterity, unchanged and unchangeable; - extreme partisans of tradition, for whom all change seems to imply betrayal of truth or else doctrinal decay, and to involve in either case the unpardonable crime of what for want of a better name we will call scholastic sacrilege. So the priests of ancient Egypt argued when they systematically excluded all foreign influences from their traditional teaching, and symbolized its abiding and immutable stability in those uncanny sphynxes that defy the work of time with their rigid, stony stare.

And, thirdly, the new compound grates intolerably

Hubert Meuffels, 1 propos d'un mot nouveau (La Quinzaine, Feloruary, igor, p. 521 ). 
on the ears of those lovers of fine language who show more concern for the sound of a word than for the idea that underlies it: to their delicate sensibility such an incongruous combination of old and new is little short of a positive torture. "Neo-scholasticism," exclaimed one of them to us recently, "No, no, impossible, impossible !" And so we find friends of the new movement influenced by esthetic considerations of consonance to substitute the title of Neo-Thomism for that of Neo-scholasticism.

Now, without defending the musical superiority of the word Neo-scholasticism, we prefer it, in the absence of a more harmonious substitute, to the term "Neo-Thomism." And our reason is a simple and intelligible one. "Neo-Thomism," or "Neo-Scotism," or indeed, any other title reminiscent of any one great medieval philosopher, labours under the obvious disadvantage that it likens the new philosophy too exclusively to the thought-system of some particular individual, whereas in reality this new philosophy is sufficiently large and comprehensive to pass beyond the doctrinal limitations of any individual thinker ${ }^{1}$ and to draw its inspiration from the whole field of scholastic philosophy as outlined in some of the preceding Sections (12-17). Moreover, Neo-scholasticism is not the same as Neo-Thomism, as we shall show later on; and hence the former expression must have our preference. The function of words is not to misrepresent but to express accurately the things they denote-and that even at the expense of a little musical consonance.

M. Meuffels has no hesitation in advocating this view of the matter in a French periodical, ${ }^{2}$ and we agree with him both on his decision itself, and on

1 From this point of view we may follow with an equal degree of interest the restoration of the teachings of St. Bonaventure and of those of St. Thomas. See, for example, the articles of Fr. Evangelist, in the Etudes franciscaines (1902 and 1903).

${ }^{2}$ I. a Quinzaine, article referred to above. 
the convincing reason he gives for it: the Neoscholasticism of the present day, like the scholasticism of the Middle Ages, is a body of doctrines, and by its doctrines it must be judged. Both those who anathematize the Middle Ages and those who adore them, have to be cured of certain optical illusions before they can see the significance of quite a number of ideas that are developing under our very eyes and have already taken their place among the most dominant factors in contemporary thought.

103. When the father of a family dies, his children do not squander away his estate on the pretext that they can assert their own personality in the world only by carving out their own fortumes independently, or that their father's property is useless for the needs of their generation. On the contrary, the son receives the patrimony bequeathed to him, as a sacred inheritance; he regards these stored-up fruits of ancestral toil as a precious capital by the use of which he can render his own labour more productive than it otherwise could be. Now, the transmission of philesophical ideas is in many points analogous to the transmission of goods of fortune. Every epoch inherits from the preceding and bequeathes to the succeeding epoch. Even systems which react against tradition, themselves contain traditional elements. Without going farther back than the earlier of the modern philosophers-men who gloried openly in demolishing tradition and scourging prejudices and preconceived ideas of all sorts-even those have been clearly convicted, so to speak, of having borrowed much, perhaps unconsciously, from the Middle Ages; and they have been justly likened by La Bruyère to ungrateful children who direct their first attacks against their own nurses. Nobler and abler men, of the stamp of Leibnitz, have bestowed on the worth and excellence of scholastic philosophy encomiums that deserve to be more widely 
bnown. ${ }^{1} \quad$ It would be worth while, from a critical point of view, to re-edit a book published in 1766 by an eclectic disciple of the Hanoverian philosopher, L. Dutens, under the curious title: Recherches sur l'origine des découvertes attribuées aux modernes, oì l'on démontre que nos plus célèbres philosophes ont puisé la plupart de leurs connaissances dans les ouvrages des anciens."

When the new scholastic philosophy proclaims by its very name its continuity with a glorious past, it is merely recognising this incontestable law of organic relationship between the doctrines of centuries. It does more, however. Its endeavour to re-establish and to plant down deeply amid the controversies of the twentieth century the principles that animated the scholasticism of the thirteenth is in itself an admission that philosophy cannot completely change from epoch to epoch; that the truth of seven hundred years ago is still the truth of to-day; that out and out relativism is an error: that down through all the oscillations of historical systems there is ever to be met with a philosophin perennis - a sort of atmosphere of truth, pure and undiluted, whose bright, clear rays have lighted up the centuries even through the shadows of the darkest and gloomiest clouds. "The truth for which Pythagoras, Plato and Aristotle sought, is the same as that pursued by St. Augustine and St.

${ }^{1}$ See, e.g. Lettre a Wagner, Op. phil. ed. Erdmann, p. 42+; De stilo phil. Nizolii, Op. phil. p. 68; Théodicée, II., n. 330. Cf. Willmann, Gesch. d. Idealismus, Vol. II., p. 533.

2 Paris, 2 vols. - Among the principal works on the relations between modern and scholastic philosophy, we may mention Glossner, $Z u r$ Frage nach dem Einfuss der Scholastik auf die neuere Philosophic (Yahrb. f. Phill. u. sp. Theol., I899); Yon Hertling, Descartes' Beziehungen zur Scholastik (Sitzungsberichte d. philos.-philol. u. histor. Klasse d. München. Akad. d. Wiss, 1899); J. Freudenthal, Spinoza und die Scholastik (in Phil. Aufsätze Ed. Zeller gewidmet, Leipzig, I887); Nostitz-Rieneck, Lcibniz u. die Scholastik (Philos. Yahvb., I894); Jasper, Leibniz u. die Scholastik (Diss), I.eipzig, I898 ; Rintelen, Leibnizen's Beziehungen zur Scholastik (Archiv. f. Gesch. d. Philus., I903). 
Thomas. - . . In so far as it is elaborated in the comrse of history, truth is the child of time; but in so far as it embodies a content that is indrpendent both of time and of history, it is the child of eternity." lor "if reasom he aneht hut a deceptive asprisation after the absolutely inacessible, surely whatever has been bromeght to light. whatered cur ancestors have unearthed and arequired in thesi pioneer labours. cannot have proved entirely worthless to posterity. • . . Instead of etemally eommeneing wrer again the sulution of the great renigma of nature and of ensocionseness. Would it not be wiser to preserese our traditional inheritanere and go om perfereting it? Cam it be better to let the intelligence live on its own persomal and "rer-incipient thenght than on the acemmulated wislom of centuries? Should we not be better empleyed in alding to that common fund of doctrine than in ehanging it every day-in the hepe of attaching ome names te some new system ?": Such is obviously the postulate" that must be aither explicitly or implicitly recornised by all of us who find in scholastiolism, and in the wealthy store of Greek thought assimilated by scholasticisin, a remarkably rlose approximation to absolute truth-closer perhaps to the ideal of true wislom than any of the contemporary forms of positivism or of Xeo-Kantism. ${ }^{3}$

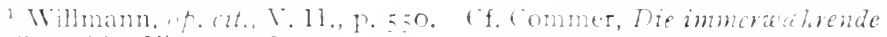
Ithitisethic (Vienna, degro).

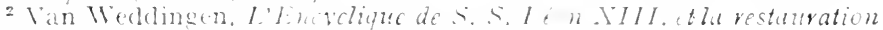

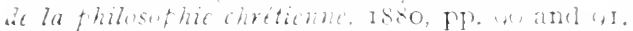

"(f. l)e Wulf, Labti-me t né-scolaticate " lor our part we helieve that extreme evolutioniom. which is hing ground every day in the special seiences, is an wnound hypothe-in when applied tophib-ophy. io cloult, history show that syetem alapt themselves to their curroumelinge, and that every age has its own proper asprations and its wn pecial way of approaching problems anel -olutions; but it also lays letore u-, clearly and unequirocally, the-pectacle of ever-repeated

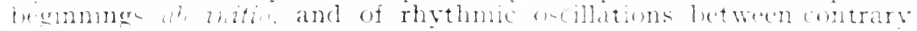
polen of thought. And if Kant liat lenum at new formula tor suti-

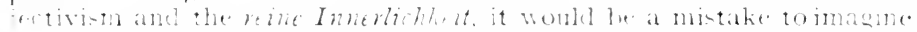




At the same time, let us hasten to add, the new scholasticism inscribes on its programme, side by side with this respect for the fundamental doctrines of tradition, another essential principle, of equal importance with the first-which it supplementsand expressed with equal clearness by the name it has chosen for itself: the principle of adaptation to modern intellectual needs and conditions. The heir to a fortune accumulated a century ago does not treat it in the same way as its compiler would in his day. For the better employment of it he avails of all the advantages to be derived from new and improved economic surroundings. He invests his capital in industrial enterprises, delivering it up to a vast and complicated currency that has little in common with the simple investments through which it earned interest for his forefathers. So it is, too, with the riches of the mind. Absolute immobility in philosophy, no less than absolute relativism, is contrary both to nature and to history. It leads only to decay and death. Vita in motu. To have scholasticism rigid and inflexible, would be to give it its death-blow, to make of it a mere caput mortuum ; an interesting relic, no doubt, but only a relic, fit indeed to figure respectably at an international exhibition of bygone systems, but fit for nothing else.

we find some of them, for M. Deussen has unearthed in the Upanishads to the Veddic hymns the distinction between the noumenon and the phenomenon, and has been able to recognise in the theory of the IIâyâ "Kants Grundlogma, so alt wie die Philosophie."

No, it is by no means proven that all truth is relative to a given time or a given latitude; nor that philosophy is the product of the natural and necessary evolution of purely economic forces. The materialist conception of history is as groundless as it is gratuitous. Alongside the changing elements that are peculiar to any given stage of development in the life of humanity, there is at every stage and in every system an abiding soul of truth-a small fraction of that full and immutable truth which hovers around the mind in its lighest flights and noblest efforts. This soul of truth it is that the new scholasticism hopes to find in certain fundamental doctrines of Aristotle and St. Thomas; and it is precisely in order to test their value that they must be cast into the crucible of modern thought and confronted with the doctrines opposed to them." (Revue N'é-Scolastique, I902, Pp. I 3 and I.4.) 
We have been more than once accused of committing a gross anachronism : of transporting bodily into the twentieth century the conceptions of the thirteenth. J. Frohschammer, the not over eritical author of a work entitled: Die Philosophie des Thomas von Aquino kritisch geviordigt. justifies the publication of his views in the following combative language:- " In the actual circumstances," he writes, "we are called upon not merely to eriticize a theoretical system but to destroy the practic..es influence which the philosophy of Thomas has acquired since he has been proclaimed commander-in-chief of the scholastic forees. The papacy, allied with Jesuitism, is utilizing these forces to the utmost for the purpose of carrying on a struggle to the death against all modern philosophy, all modern science and cren against civilization itself ; and that, in order to erect upon their ruins the temporal supremacy of the papacy as well as the scholastic science and civilization of the Midalle Ages." (!) Professor Eucken, while, freely admitting the historical value of Thomism, thinks that it has no permanent or absolute value, and that an attempt to rehabilitate its leading doctrines would be tantamount to denying the progress of humanity and putting a clog upon the wheel of time (das Rad der Weltgeschichte zurïkdrehen). ${ }^{3} \quad$ Maurenbrecher naively jokes at the Neo-Thomism, "which fails to see how utterly impossible it would be to resurrect the social organism of St. Thomas' age." And II. Secretan pronounces the following prejudiced and summary condemnation of the new movement: "There can be no possible understanding," he writes, "between science and a

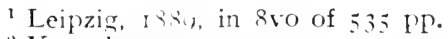

$\because$ Vorrede, $\mathrm{p}$. $v$.

"Thomas $\because$. Aquin u. Kant. Ein Kampf zweier Welten (Kantstudien, IonI, Bil. VI., pl. Io-I I and i 8).

'Thumas nu Aquino's Stellung zum Wirthschaftshben seiner 7at (Leipzig, I 899$),$ P. 50. 
school of philosophy that proclaims every question already settled as it turns up, or settles it then and there by an appeal to authority." 1

Quotations might be multiplied indefinitely. But we may assure such writers that there is no need for alarm: that they have only to disillusion themselves and make their minds easy. The promoters of the new scholastic movement will have none of that puerile psittacism which contents itself with repeating lessons learned by heart; they are quite aware that an archaic renaissance is not unlike a death-agony. From the fruitless efforts of the fifteenth century philosophers to revive, in their original form, Platonism or Aristotelianism, Stoicism or Atomism, history has gathered a lesson that wught to open the eyes of the blindest. Besides, we find that those who have pronounced on the meaning and scope of the new scholasticism in recent years are all unanimous in declaring that if this philosophy contains a soul of truth in it it should be able to fit in with all the advances made, and all the progress realized, since the Middle Ages, and to open wide its arms to all the rich fruits of modern culture.

Talamo advocates this work of modernization. ${ }^{2}$ Gutberlet, the learned Fulda professor, outlines a similar programme in an article in the Philosophisches Yahrbuch, espousing the philosophical system of St. Thomas, in order to complete and improve and correct it. ${ }^{3}$ As Dr. Ehrhard of Strassburg has so well expressed it: "St. Thomas of Aquin should be a beacon (Lichtthurm) to us, but not a boundary (Grenzstein). . . . The needs of any epoch are peculiar to that epoch, and will never repeat

\footnotetext{
${ }^{1}$ La restauration du thomisme (Revue philosophique, I884, V. II., p. 87$)$.

"L'Aristotélisme de la scolastique dans l'histoire de la philosophze (Paris, I 876 ), Conclusion, p. 531 .

"Die Aufgabe der christlichen Philosophie in der Gegenwart (Phil. Yahrb., I888, pp. I-23.)
} 
themselves." Likederlarations have been frequent!y" repeated by the professors of the Ionvain Philosophical Institute, and by their official organ. the Rerue Néerscolastique." They have been erehoed over and over again he Mgr. d'Hulst. ${ }^{3}$ Kaufmann, ${ }^{4}$ Hettinger. ${ }^{5}$ Ieuffels..$^{*}$ Scchneid. ${ }^{7}$ etc.. all of whom refer to the well-knewn advice of Leo XIII.: "We proclaim that every wise thought and every useful discovery ought to be gladly weleomed and gratefully received by us, whaterer its origin may have been.".

104. To sum up, The whole aim and object of the new revival of ideas to be treated in the subsequent pages of the present work, is just simply the realization

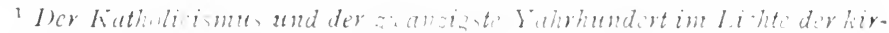

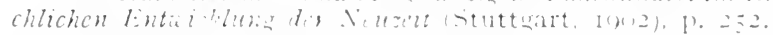

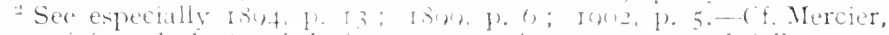

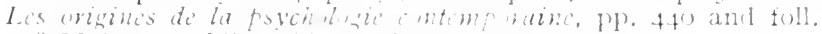

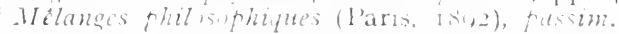

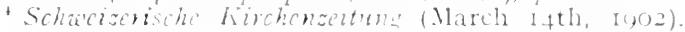

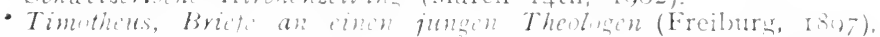

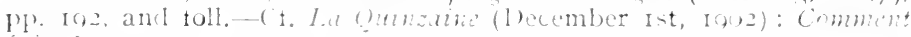
fuive?

" "Rightly unlerstood, therefore, the new scholasticism is no mere re-eliting, no mere sistematic and uncritical ju-titication ot everything that has been, rightly or wrongly, labelled with the elantic title of 'Scholastic I'hilosophy. The new scholanticism has all that is lent in medieval schola-ticinm, enriched and completed, morenver, by modern science, arlapted to the needs of rinr times, directed in its tendencies by the spirit and teaching of the I'apal Encrelical. In wther words: the aim and object of the new scholasticinim i- ever to go on increasing and arlapting to present needs the patrimony of truths bejueathed to us loy those who have gone before 11s, and especially by st. Thomas iquinas." I propos d'un mot noureall. 1. 527. [See alon a series of four articles in the Irish Ecclesiasticul liccord (Jan., Feb., May and June, 1905), in which we have discusisert the scholastic view of the relations between philosophy and the sciences. and described how these relations are realized in practice in the teaching of the Philosophical Institute of the Catholic [ niver-ity of Louvin. (if. Appendix, intra.-Tr.]

" Die Philusuthie d. hl. Thonas und in Bedeutung fïrdic Gerenwart (Wurzbure. Issi), p. $7+$.

"Encyclical Aitemi l'atris. Picavet, who is no scholastic, makes this candid plea for the new movement: "Why, if there be a new Cartesianism, a new Leibnitzianism, a new Kantism, should there not be aloo a new Thomism? We think we have shown clearly enough that the millions of Catholic: who with I.eo Xll. proclaim their allegiance to Thomism, have not the slightent intention to become mere echon of the thirteenth century, nor to leave out of account, in constructing their syotem, the researches and dincoveries of molern science." (Rew philos., 130., vol. 35, P. 3.5.) 
of that characteristic and perfectly justifiable union of a borrowed element - the traditional scholasticismwith a new and original element. Just as in the Middle Ages scholasticism grew and developed from its own inner vital principle, after assimilating Greek and Patristic ideas, so will the new scholasticism be animated by its own proper spirit all the while that it feeds on medieval ideas in the full light of the twentieth century. And what are the factors of this new spirit, or how far is the new scholasticism likely to modify the old? We shall try to outline an answer to these questions in the paragraphs that follow. By keeping to the order of Part I. we shall be able to compare the past with the present, and so to meet all the questions of more particular interest in the study of contemporary scholasticism. This first chapter deals mainly with the external relations (6) of the new scholasticism (Sections 20-24). The second will treat of the doctrine itself (Sections 25-33).

\section{Section 21.-measures for teaching and PROPAGANDISM.}

105. Is the new scholasticism the "child of the schools"? Just as much as, but no more than, positivism or Kantism or pantheism or the philosophy of immanence. It is propagated by teaching. but also by all the manifold forms of modern printing: books, pamphlets, reviews, even newspapers have helped to spread its doctrines. Quite a large bibliography of the new scholasticism has grown up within the past two decades.

A person would certainly provoke a smile at the present day, if, under pretext of reviving the past, he tried to propagate his ideas through the sole medium of manuscripts, refusing to have anything 
whatever to do with the printing-press. The most extreme reactionaries would scarcely venture to push absurtity so far. Neither would they venture to rehabilitate the ancient trivium and quadrivium (16 and 17). nor to put into force oner more in our modern universities the edict issued in 1:25.5 by the faculty of arts in Paris (48). Mrenerer. the historical continuity of teaching methods has been completely interrupted. Far-reaching innovations have been introduced. And these in a cortain measure reflect the progress of the doctrines themselves convered hy them.

The commentary, which formed the chief rehiche of instruction in the thirtenth eentury (17). has been longr since abandomed in favour of a systematio. expesition of the various branches of philesophy. The latter method is much better (alculated to give the sturdent a mified view of all philosophy. while at the same time it prerents useless repetitions. !t also malses it rasier for us to enrich the new scholastieism with doctrines borrowed from other systems whenever that may be neressary, as well as to make better use of the findings of the rarions speedal sciences. Wre could eount on our fingers those who would limit the work of restoration to a simple exposition of the philosophy of St. Thomas ${ }^{\prime}$ in all its fulness and in the order he himself followed." In the opinion of Fr. Janvier, any other method than the latter would be a misguided adrocacy of Thomism. "The most enlightened and right-minded scholastics," he writes, "took the Eneyclical of Leo XIII literally, and proceeded to expound the whole teaching of st. Thomas following both the method and the style of the Ingelic Doctor himsell." But Fr. Janvier's expression of opinion calied forth numerous protests, even unexpected protests; and we have every reason to be glad that it did so. 
At the same time the commentary will still prove useful, whether for the thorough investigation of special questions in which the explanation of isolated texts could easily be of the greatest importance, or in the more advanced studies for the doctorate when an exhaustive analysis of some Aristotelian or scholastic treatise is prescribed. This, in fact, is the method of teaching followed in most of our modern universities, and it shows excellent results. The formal setting of a question by the application of the well-known triple process "Videtur quod-Sed contra-Respondeo dicendum," as also the use of the syllogism, are too valuable as didactic methods to allow them to lapse, or to deprive the new scholasticism of their services $(19,20)$. But the continuance of such methods does not exclude their adaptation to the modern mind. Nothing can redeem the monctony of dissecting human thought after a stereotyped method, and by a constant repetition of the same rigid formulæ. The inevitable outcome of such a system is an arid and barren formalism that provokes weariness if not disgust. The exposition of reasons for and against, the answering of objections, the vigorous syllogistic demonstrations: all these processes gain immensely in attractiveness, without losing a particle of their force, when they are stripped of their medieval garments and presented to the twentieth century in a somewhat more modern dress. The matter is simply beyond discussion so far as works in philosophy are concerned; the idea of writing a treatise on criteriology or a book on contemporary psychology, after the manner and style of the Summa Theologica or the Quodlibeta, would be simply barbarous.

And so, too, of oral teaching. That students should be taught by means of discussions and practical exercises to put an argument "in form" and to answer it; that they should learn, by the searching 
application of distinction and sub-distinction, to detect the latent vice or weakness of a doctrine: by all means; that is most essential. But let them learn also to despise mere sophistry and to avoid the intolerable abuse of juggling and trifling with formula (Section 3:3). Let them learn to grapple with reality and to shake off the delusion that all knowledge is crystallized in the phrases of their daily lessons.

106. There are. besides, certain new didactic methods which custom has universally astablished in other domains: it would be very unwise not to employ those methods, which are the fruits of modern progress, for the benefit of the new scholasticism. 'The thirteenth century had thoroughly organized and availed of public discussion; this is supplemented nowadare by the momogreph and the disserlation, at certain stages of the student's course. For the latter, hy putting his hand to such work, learns to think for himself-and to express his thoughts. Above all, our teaching methods would profit immensely by the introduction and use of laboratories and of what the Germans call the seminar, or class for practical tuition.

The idea of a "laboratory" in connection with the teaching of philosophy may possibly provolie a smile. Nevertheless, alongside the libraries and reading rooms, which might be called the laboratories of the speculative departments of philosophy, there is really a place and a demand for experimental science laboratories (psycho-physiology, physics. chemistry)-once you admit that the new scholasticism ought to refresh and reanimate itself by contact with the experimental and rational sciences (Soction :2t).

The "practical seminary" -where a small circle of students devote themselves, with the help and direction of thrir professor, to the study of some 
special question-can be employed with profit in all departments of philosophy: its good results have been everywhere in evidence. In work of this lind, where each contributes his share to the achievement of some common purpose, each will have the benefit of the others' researches; the right methods of investigation and the proper use of instruments and means of research will be learned by actual practice; the student will be brought into contact with the construcive or inventive methods in use in the various branches of his studies; and in this way his tastes will often be fostered for some particular line of work, and his intellectual vocation often definitely decided by some success that may have crowned his initial efforts.

107. In regard to teaching methods there is a final question which divides even the most sincere and well-meaning among scholastics: in what language should the new scholasticism be taught? Must we retain the philosophical Latin of the Middle Ages, the language of the great scholastics themselves whose deep and wholesome doctrines we would fain perpetuate? Or should we boldly translate into the living languages the exact and delicate formulæ which make the scholastic idiom unintelligible except to the initiated?

The sermons of Master Eckhart (circa, 1260-1327), who, with all his peculiar views, was really a scholastic, may be regarded as the first beginnings of a German literature; and, in common with the works of Raymond Lully, they are among the earliest applications of a living language to philosophy. But for long after their time Latin remained the common language of all educated people in the West. Then the Humanism of the Renaissance came along and gave it a new lease of life which lasted for two centuries. The philosophy of the fifteenth century became the battie-ground of two kinds of latinity: 
the scholastic Latin which became more and more barbarous, corrupted as it was by the decay of the doctrine itself (except in the Spanish and Portuguese authors of the sixteenth century), and the classical Latin, cultivated for its own sake by a group of writers less concerned for the thought itself than for the expression of it. The earliest of the "modern" philosophers, Descartes, Bacon and Leibnitz, wrote partly in Latin and partly in their vernacular: but in the eighteenth century the various vernaculars almost universally supplanted their common rival. The nineteenth century confirmed the modern usage: at the present day very little philosophy is written in Latin, and the speaking of it in Latin is practically confined to the public displays of defending theses for academic degrees.

108. As an exception to this general movement we must recognise the existence of a large and influential group of scholastics who boldly undertook the revival of the medieval doctrines in the second half of the century just elapsed, and whose vigorous propaganda has certainly contributed much to the restoration which has now become so widespread. Their example has been followed by most professors of scholastic philosophy-especially in the ecclesiastical seminaries and colleges where special reasons, the force of which we freely recognise, oblige the students to familiarize themselves with the official language of the Church.

Apart from those considerations of tradition and ecclesiastical discipline which we do not wish to mix up with this dispute, the reasons which the "latinists"

1 The question has been discused from this point of view by $M$. Neutfels in the Rezue Né-Sculastique of February and November. I903; and by Hogan in his Clerical studies. The same aspect of it has also heen dealt with by Count Domet de Vorges in the Roure Véo-Scolastique, I903, p. 253.-See also: Kihn, Encralopadie u. Methodologic der The logie (Fribourg, I 892), pp. 95-90, and Mgr. Latty, D) l'usage de la langue latine dans l'unseisn ment de la théclogic (Chalons, I0O:!. 
bring forward are mainly drawn from the pedagogic excellence of the Latin language in the matter of scholasticism: this philosophy, they tell us, is so closely bound up with the phrases and formulæ, the expressions and idiom, in which it was embodied in the Middle Ages, that these are practically inseparable from the doctrine itself. From which they infer that we must continue to teach and to write scholastic philosophy in the twentieth century in the self-same Latin which was its natural vehicle in the thirteenth.

To that which is their main argument, they add this other consideration: that the propagation of the doctrine itself will be helped on by the employ.ment of one common "language of learning," which, being intelligible to all, will surmount the obstacles arising from differences of race and country, and facilitate intellectual intercourse between all who take part in the common work of scholastic reconstruction.

In theory, no one has ever denied the very great value of Latin, as a historical fact, in scholastic pedagogy; and the employment of that language, were it accepted by all, would probably render as much service in the twentieth century as it rendered in the thirteenth. But the question, formulated in such terms as these, belongs to the abstract and ideal order; and it might have quite another solution were it made concrete and practical. And as a matter of fact the supporters of vernacular teaching insist that the new scholasticism must take into account the age and the surroundings in which it has to live and to assert itself, and, above all, the intellectual atmosphere breathed by the learned men of our time-an atmosphere which is the outcome of certain factors peculiar to modern life. To ignore all these considerations would be simply to work not for our contemporaries but for the vanished figures 
of history; it would be sowing the living word in the desert. But the moment we take these new elements into consideration the whole perdagogical problem of the language of philosophy assumes a totally different aspect.

In the first place, this at all roents is clear. that if we take the latinists entention in the exclusive sense of denying the possibility of teaching scholantic philosophy in any modern language, the contention is certainly extreme and monjustiable. It rests on a confusion of ideas. Sereing that the scholasties have written in Latin, of entres an intimate acplatintance with their latinity is an essential condition for understanding their doctrine or encompassing its revival-just as one must understand samserit or Greek in order to speak with authority on the Epanishads or on Aristotle. In fact, we must strongly insist on the necessity of a therenghte-going scherlastic phitology. for it is an indispensable aid to the study of medieval philosophy. It is preceisely for want if such an equipment - which can be had only thromgh special training and initiation-that many of our molern historians of medieval institutions ammit such deplorable mistakes. ${ }^{1}$ Missing the technical meaning of a word or of a phrase, they credit the scholastics with absurd and unmeaning theories, and accuse them of errors for which their own ignorance alone is accountable.

Therefore a thorough linowledge of scholastic Latin is of the first importance. But it is one thing to understand the language in which an author has written, and another thing altogether to make use of that same language to express that author's ideas, to discuss their meaning, their origin, their merits and their defects, with all the developments that such a work of exegesis implies. If a philosopher undertake to explain the theory of the retman or

$$
\text { Seee, for sample, P. I } 2 \text {, n. I. }
$$


of the siors he should be fully conversant with the meaning of the Sanscrit or of the Greek term, but he need not necessarily write or deliver his lectures on those subjects in Greek or in Sanscrit. Any language of normal development will furnish the materials needed for the expression of any idea whatsoever, provided they are managed by skilful hands and suitably chosen for the ideas they are intended to embody. Every normal language will be found capable of expressing any stock of ideas. That many of our modern languages do combine the requisite conditions of richness and flexibility-who will venture to deny? We have a sufficient proof of it in one single work : Fr. Kleutgen's well-known volumes, which have done so much for the spread of scholastic ideas, were written originally in German (Vie Philosophie der Vorzeit vertheidigt), ${ }^{1}$ and afterwards translated into French and Italian (La philosophie scolastique exposée et défendue; La filosofia antica esposita e difesa). ${ }^{2}$ And personal experience-which others will still confirm with theirs-has amply proved the superiority of that work over many a Latin treatise, even from the simple point of view of doctrinal interpretation. Other examples might be added. In short, the facts have already proved that scholastic thought is by no means immovably embedded in its medieval setting. Latin is not a sort of epidermis that may not be removed without flaying or disfiguring the doctrine itself. Hence, at the very least, it cannot claim a monopoly in the teaching of scholastic philosophy.

Then, furthermore, those who would support the strange contention that an author must be expounded in the language in which he wrote, would be putting the scholastics of the Middle Ages in a very awkward position. For the world knows that their

1 Second edition, 2 vols. Innsbruck, is 78.

2 Four vols., Paris, 1868-1870; five vols., Rome, IS66-1868. 
commentaries on Aristotle are not in Greek but in Latin ; nay. eren that they had to use Latin translations in studying Aristotle themselves: we could coment on our tingers the Western scholars who could read Greek between the ninth and the fourteenth centuries. And ret whe will venture to say that. the medieval scholasties diel not thoroughly understand and rxpesund Aristotle?

ds to the alvantages of having one common language of learning, they are too obvious to be disputed. But here again wo are only chasing shadows: contace with actual facts will give a rude shatie to our fancies. Wr are not now living in the conditions that obtained in the Midelle Ages. The modern languages have bern built up slowly and gratdually : and they hare inherited a long leasio of life from deep and wide divergences of national manners and customs, ideas and traditions. Moreover there is not one of the four or five great European languages that has not been most successfully employed in the service of philosephic thought by men of the highest genius: and their imitators are simply legion. The repeated deplorable failures both of individual and of organized effort to secure the recognition of some one common language of learning, should be a sufficiently clear index to the sort of results likely to be achieved by the promoters of such an utopia: especially seeing that the men who are trying to stem such an irresistible current must at the same time struggle against a multitude of other difficulties which have hitherto prevented sincere and unprejudiced minds from appreciating the real value of the new scholasticism. Practically it will come to this in the long run, or rather indered it has come to this already, that we simply must familiariz: ourselves-and it is not a very difficult task-with at least the more important of the modern languages. 109. So far, we have been suggesting considerations 
more of a defensive nature against a claim which is, to say the very least, exaggerated. On the other hand, the claim of those who support the modern languages gains enormously in force and persuasiveness, when we begin to reflect on the many serious disadvantages connected with the use of Latin nowadays in our schools. If we would secure an abiding vitality and influence for the new scholasticism, we must force an entrance for it, at any cost, into those indifferent or hostile circles from which its very name has hitherto sufficed to exclude it. It is not by shutting itself up in secluded class-halls, nor by receiving the incense of a small coterie of select admirers, that modern scholasticism is to accomplish the important mission intended for it by those who are devoting their lives to its propagation. It must be brought into touch with the modern mind, with all the main currents of ideas that are shaping the mentality of the age we live in. We must give it an opportunity of stating and supporting its reasons and arguments, of opposing its solutions to rival solutions; in a word, we must secure currency for it in the world of contemporary thought.

Now, is it by the use of Latin that it is likely to force an entrance into those quarters from which it has been so long exiled? It certainly is not. It will knock in vain at the library door of the Positivist or Neo-Kantian if it finds its way thither embodied in ponderous Latin volumes. It will meet with the reception usually accorded to inconvenient visitors. It will be considered an anachronism-as archaic and out of date as the cut of its clothing-and put aside with the simple remark that it can have no use or interest except for Church folk.

So true is this that if certain modern publications on scholasticism have attracted attention and provoked serious - and earnest discussion in quarters where quite other doctrines were holding undisputed 
sway, these publications must be sought, not amongst learned Latin treatises, but among the works that breathe a modern spirit and are written in a living tongue. Nor would it be anything short of an illusion to imagine that at least those who are friends of the Middle Ages and restorers of its philosophy should find in Latin a special help, an additional stimulus to work. Here again the dead language of another age is only a source of trouble and delay. Indeed with the exception of a few remarkable personalities belonging for the most part to Roman or Italian centres of learning, where by foree of national tradition the study of Latin was held in honour, it must be admitted that quite a multitude of philosophical manuals are written in a style that is only very remotely reminiscent. we will not say of Cicero's elegant latinity, but "ren of the standard philosophical latinity of the Middle Ages. And what are we to say of the Latin spoken in the class-halls both by professors and by students? Does it not, for the most part, reach the low level of what we might fairly describe as jargon? Then, does anyone seriously believe that the beginner, while yet quite a stranger to the effort and the habit of philosophical thought, can possibly feel at ease within the cramping confines of an unfamiliar language? A teacher of ripe experience, who has had abundant opportunities of judging the tree by its fruits, has spoken in the following terms of the difficulties of the youthful student: "A second difficulty, of the most serious kind and common to all beginners, arises from the utter strangeness of the new field that is opened up to their activity. . . . All is new and difficult -the notions, the terms, the methods and the language. [The student] is suddenly introduced into a world of abstract ideas hitherto unknown. And then, Latin, as a vehicle of thought, is unfamiliar to him. Even the old, well-known truths assume strange 
and, to him, unnatural forms, whilst the terminology of the schools is obscure and bewildering. $\mathrm{He}$ is soon lost, as in a fog. . . . Some never emerge from the gloom, and even those who do always remember it as the most trying period of their intellectual formation." And further on, he says: "It has been the experience of the writer for many years that, of those who have been taught philosophy, and especially scholastic philosophy, only in Latin, not more than one in half a dozen had brought away with him much more than a set of formulas, with only a very imperfect notion of their meaning, though not unfrequently accompanied by a strong determination to cling to them all, indiscriminately and at any cost.",

Dr. Hogan, the late venerated president of the Boston Seminary, refers in those passages only to ecclesiastical students, who have such incentives, apart altogether from philosophy, to preserve and to utilize their store of latinity. In the case of lay students, therefore, who are attracted to the study of philosophy only by a strong, disinterested love for truth, and a praiseworthy ambition to explore the great problems of the world and of life, this anachronism of language becomes, unfortunately, a disastrous and insurmountable obstacle. Of that we have had sad experience in the Louvain Philosophical Institute, to which the writer has the honour to belong. From 1895 to 1898 , the courses were given in Latin : the experiment had practically the effect of an interdict; the lay students withdrew,

1 Hogan, Clerical Studies, pp. 64, 65.

2 Ibid., p. 70.-Similarly, Count Domet de Vorges very justly remarks that "Oftentimes students imagine they have grasped an idea when they are only repeating a formula. And even professors are not exempt from this danger. They may think they have the solution of a question in certain high-sounding phrases which make an impression because uttered in a strange language. It has often occurred to us, in reading modern manuals, that the author would not have dared to defend his thesis in the vernacular." Revue Néo. Scolastique, I903, article referred to above, p. I72. 
leaving in the class-halls only the ecclesiastics, who were obliged to follow the lessons. The withdrawal of the regulation in 1898 just saved the institution which had been led to the brink of ruin. ${ }^{1}$

It is also for reasons analogous to those that certain work's in Latin, by men of the highest ability, have attained to such scanty publicity, scarcely finding their way beyond a quite restricted professional circle: while if they had been written in a living language they would have undoubtedly secured in widespread and favourable reception.

In philosophy, just as in "rery other domain of thought, the author or professor, whether he likes it or not. must take account of the tastes and tendencies of the public; because these are simply indications of the mental attitude of a given state of socinty. The dry and stilted forms of language that satisfied the medieval philosopher's will not be tolerated at the present day. The moderns have trained us to expect and to demand a literary clothing for even the most abstract ideas-the French, especially. who have in Deseartes a master of style no less than a leader of thought. Unless the new scholasticism caters for those requirements in educated circles it will not be received there. Not that we are to write literature instead of philosophy, but at least that we ought to please and respect our public by addressing them in language sufficiently clear and pure and simple to make even the most abstruse and abstract of our theories easily intelligible.

For that reason, then, Latin has little chance of fixing the attention of the public in philosophical circles. There is furthermore this additional reason: we have a whole department of ideas in which the disadvantages of Latin are so manifest that even the most extreme "latinists" are disposed to bend their principles to the needs of the case : the department ${ }^{1}$ [Cf. Appendix, infra.-Tr.]. 
of the history of philosophy, including the consideration of modern scientific researches.

(Sections 22 and 24). How could we deal in Latin with Kant, Hegel, Spencer, Taine, Renouvier, Boutroux, Wundt ; or treat of psychophysiology, sociology, etc., without coining a vocabulary of strange and displeasing neologisms?

110. The contradictory positions we have so far outlined, together with their respective lines of defence, will be found to involve ultimately the very essentials of the new scholastic programme; for they spring from two widely different conceptions of the nature and scope of the revival in question. If we are simply and solely to take up and teach once more the scholastic synthesis of the thirteenth century, then indeed a dead language will best suit a dead system-a system far removed from all the actual influences of the present age. But if on the contrary the revival of that ancient synthesis is to be a real revival, if we are to breathe into it a genuine and healthy vital energy by adapting it to our actual and present needs-and there is absolutely no other way of vitalizing it-then must the new scholasticism speak the language of the twentieth century.

Surely, it is the latter of these two ideals we ought to aim at realizing? And if so, the teaching of scholastic philosophy, in book and in pulpit alike, must be modernized. A sound philological study of the great authors of the thirteenth century-an exegesis of their terminology, together with the reading and explanation of some texts-will amply supply for the Latin pedagogy of the past. Those of us who have been led by this method into a knowledge of the scholastic authors-we ourselves are of the number-have only to congratulate ourselves on the suitability and general excellence of such a mode of procedure. 
SeCtion 22. -THE NEW SCHOLASTICISM AND THE HISTORY OF PHILOSOPHY.

111. The history of philosophy was not altogether unknown in the Middle Ages (21). But within the last fifty years history has taken such an important place among higher studies that we must define exactly the attitude of contemporary scholasticism towards this particular department of seientific research.

Many causes have eontributed to bring about the present-day enthusiasm for historical studies. There is, for example, the influence of Cousin's eclecticism in France, and of Hegel's idealistic evolutionism in Germany ; the history of philosophy was employed by both these writers, though in different ways, as an essential constituent part of their philosophical systems. Then also, historical research is in no small measure the outcome of that irresistible craving for knowledge which is so characteristic of our time, and which has been the mainspring of the natural, as it now is of the historical sciences.

Every human fact in past history possesses its own proper interest: for it may one day become an important item in some great work of systematization. And if it has any connection, remote or proximate, with philosophical conceptions, it may account more or less fully for the influence of some personality in the formation or filiation of systems, or for the effects of a certain trend of thought on a given state of society, and so for several other things. The study of the history of philosophy, like the study of any other science, is a department of the general search after truth; and that alone is enough to justify its existence. Enough also to justify us in expecting from the historian of philosophy the full use of those critical methods which the second 
half of the nineteenth century has proved to be indispensable for the scientific study of history.

However, this all-important rôle of the history of philosophy escaped the notice of the medieval scholastics. Hence the defects already referred to : a want of exactness in registering the historical fact as such, a certain carelessness in attributing an opinion or a text to its real author, looseness and consequent inaccuracy of quotation, etc. (21). At that time, history was regarded as serving another purpose : as embodying for us the soul of truth contained in every philosophical system; as helping to refute anti-scholastic theories, and in this way confirming the doctrinal soundness of scholasticism itself. This second motive for cultivating the study of the history of philosophy was of the first importance from the medieval point of view. Moderns, on the other hand, regard it as of minor importance ; though, of course, as a matter of fact, any system of philosophy is bound to derive the greatest possible advantages from the criticism and control of an historical audit.

This remarkable difference of standpoint between medievals and moderns arises rather from the mental attitude of the latter than from any purely historical cause ; most of our modern historians of philosophy have no philosophical convictions themselves, and are careful not to have any. So great is the chaos of modern ideas and systems that few have the courage to take up a definite attitude and defend it. The majority are reluctant to commit themselves to any even moderately comprehensive system, because the world of thought is perhaps more than ever a prey to contradictions; and perhaps, too, because it is not always easy to square one's life with one's principles-especially if these be of a dogmatic and decided character. Hence it is that nowadays we so commonly find an easy-going sort of scepticism supplanting all conviction, and that 
instead of trying to build up some system or other of philosophy for themselves so many are content with criticizing the systems of others. The modern attitude, therefore, on this matter, is the very antipodes of that of the medieval writers. This opposition, however, does not spring from the nature. of things, but rather from the mental outlook of a certain group of historians; the two principal reasons for the study of the history of philosophy-the reasons just referred to-so far from excluding, actually supplement and complete each other; and both alike will have their woight with the scholastics of the twentieth century.

112. For should these latter hold aloof from the great works of historical research that are being carried on in all departments of study? Or should they allow the history of philosophy to be written without them? They should not. If they ignored this important instrument of scientific progress and perpetuated the defects that were excusable in the Middle Ages, but are not so at the present diy, they would be showing a culpable narrowmindedness and fostering a prejudice that might prove very injurious to the new scholasticism. To do good work in the history of philosophy, one must be a philosopher no less than an historian. Let modern scholastics, therefore, take part in this work; let them step resolutely into the great movement and bring to light the truth at any cost. Above all, let there be an end, once and for all, to the petty and illiberal attitude shown in certain quarters towards historical studies. ${ }^{1}$ Let us

${ }^{1}$ It will scarcely be believed that up to a few years ago no history of philosophy was taught at the Gregorian University. It is still a dead letter in multitudes of seminaries. Orti y Lara, of Madrid, regarls the historical study of philosophy as an idle bibliomania. See I.utoslawski, Kant in Spanien (Kantstudien, I897, Bd. I. l'). 217-23I). Cornoldi (Filosofia scolastica speculativa di S. Tommuse d'Aqumo, p. 22, French edition) (lescribes the history of modern philosophical systems as "the history of the intellectual aberrations. of man . . . the pathology of human reason." Dealing with 
give up condensing the doctrines of others into a few syllogisms for the purpose of refuting it by a few distinctions. Those synoptic refutations of Cartesianism, ${ }^{1}$ Positivism or Kantism, adorned with

those despisers of history the Abbé Besse gives utterance to these bitter truths: "Defenders of tradition," he writes, "they have become its prisoners, and that not a little blindly-seeking to know it only in its official framework. And they have scarcely a glimmer of the historical sense. They seem to have no idea of all that is to be gained by an intimate familiarity with the whole train of events and ideas that have accompanied each successive step in the systematization of thought, each new contribution to the expressive powers of language. Their philosophy is without either topography or chronology. It seems to belong to no age; but simply to issue from the darkness of night and to vanish into it again." Deux centres du mouvement thomiste: Rome et Louvain (Revue du Clergé francais, I902. Reprint, p. 34). [Cf. Irish Ecclesiastical Record, May, I905, Philosophy and the Sciences at Louvain, p. 40o. Cf. Appendix, infra.-Tr.]

1 We cannot resist the temptation to quote the passage from the Journal d'un évêque, where M. Fonsegrive, the learned editor of the Quinzaine, gives a brilliant pen-picture of a performance of this kind : "From the heights of his professorial pulpit, to an audience of some forty youths in soutane and seated on benches before him, a priest of about thirty years was expounding a Latin textbook-in Latinand the unfortunate man, instead of endeavouring to speak the simple, technical Latin that would have been fairly easy to understand, was actually trying to improve on it, to beautify it, as he thought, by plentifully sprinkling it with Jam enim's and Verum enim vero's, and winding up his periods with Essc videatur's. In fact, he was merely repeating-less clearly-the text that lay before him, without adding to it a single example or a single idea. Yet the pupils seem to drink in his words without taking a note, some of them bent conscientiously over their textbooks, others sitting bolt upright with their eyes fixed on the professor-except when they stealthily cast them on ourselves.

The subject of the lesson was the question of the Cartesian doubt; and the professor followed the author through his exposition of the six reasons-neither more nor less, for he proved even that-on account of which the Cartesian doubt could not be accepted. Refellitur, refutatur Cartesius, repeated the professor again and again, apparently without ever dreaming of taking the trouble to point out the reasons that influenced Descartes to formulate his doubt in such terms, or to explain the rôle assigned by Descartes to his hyperbolic doubt in the process of acquiring scientific knowledge. Refellitur, refutatur Cartesius - they did not get beyond that. The pupils went away convinced that Descartes' whole conception of things was fundamentally unsound, that he was himself utterly absurd, and must have been animated with the most perverse and incurable antipathy towards truth. That day, they excommunicated Descartes for ever from the world of thought; indeed their professor proceeded more by way of anathema than of discussion. For, discussion implies an understanding of what is discussed: elementary good faith demands so much: and understanding implies study. But this professor who had just so airily refuted Descartes had never read him-not even the Discours de la methode. I saw that at once when talking to him immediately after class." Yves le Querdec, Journal d'un ivêque (Paris, I897), p. I., pp. I I6-I I8. 
a goodly number of uncomplimentary epithets, only reveal the ignorance of the pseudo-critics. We know of a certain treatise on Theodicy in which Fichte is accused of claiming for man the power of creating God as a "thing-in-Himself," whereas according to the Wissenschaftslehre the non-ego is evidently produced not as a "thing-in-itself," but merely as a representation!

It is only fair, howerer, not to make the picture unduly dark. We gladly and respectfully recognise the existence of an important and growing group of scholastics who are thoroughly devoted to historical studies Bäumker. Ehrle, Denifle, Willmann, Mandonnet, Domet de Vorges, and many others besides, have completely broken with the old, cramping ('onditions.

113. Moreover, it can be scarcely necessary to remind the reader that the study of the history of philosophy is in perfect accord with the spirit of scholasticism. If devotion to historical fact is its own justification, it also furnishes those who believe in the possibility of certitude with the additional doctrinal advantages which recommended it to the ancients. Greek philosophy had in a manner "volved, by a gradual process, all the main solutions of the great philosophical problems ; and its influence was profoundly felt by medieval scholasticism. It must be of the greatest importance, therefore, to be able to recognise and appreciate the peculiar and specific manner in which the genius of the Greeks ronceived the various theories and arguments put forth by them: to trace through all their eddying currents and cross-currents the development of those great ideas that were destined to live on amid all change, to survive all decay, and to vitalize philosophy for the Fathers of the Church, for the medieval scholastics and for the founders and exponents of modern systems. 
The history of medieval philosophy has a special interest for those of us who aim at expounding, perfecting and popularizing its principal systemscholasticism. It trains us to discriminate between what is essential and what is merely accessory in the latter; it teaches us-as nothing else can-that principles whose truth is abiding and perennial, can be applied to the new data of the twentieth century no less successfully than they were applied to those of the Middle Ages. The various polemics and controversies of the medieval scholastics lose most if not all their meaning when taken out of their historical setting: ${ }^{1}$ those problems have developed from epoch to epoch; and their very evolutions are a proof that scholasticism has steadily moved with the march of thought, however slow may have been the stages. of its progress. Finally, those historical studies bring to light the mistakes of the scholastics, their doctrinal errors and the consequences they suffered from them. What an education for those who are wise enough to profit by the salutary lessons drawn from the experience of centuries !

1 In St. Thomas' psychology there is an argument for the immortality of the soul, which is unintelligible except in the light of the historical development of ideas in the Middle Ages. The Angelic Doctor asserts the principle that the more the soul is liberated from corporeal conditions and limitations the more capable it becomes of those noblest speculations which are the glory and the pride of humanity; and he accordingly concludes that its complete separation from the body cannot possibly be a cause or occasion of its annihilation. Such an argument is entirely out of joint with the Thomistic theory of the nutural union between soul and body. But it finds its explanation in the fact that certain Neo-Platonic and Augustinian ideas had percolated here and there into medieval scholasticism: it is based on some of these foreign elements. Elsewhere, too, with history in hand, it would be easy to point out that theories like divine exemplarism in ontology, and arguments like that from the incommutabilia vera in natural theology, though accepted by Roman authors and regarded by them as the purest Thomism, were never really accepted by St. Thomas in the form in which they are usually presented. Those authors are Thomist in intention, but anti-Thomist in reality owing to their neglect of history. See further examples in Besse, op. cit., p. 35 .

3 The historical exploration of the Middle Ages is, moreover, one of the forms, or, at the very least, an important index, of the contemporary return to scholasticism. See the general outline of those researches given above, pp. 6 and 7 . 
In the last place, modern and contemporary philosophy should have a liberal share of attention in those historical studies, for this philosophy is the very soul of the intellectual civilization in which the new scholasticism in fighting for a place. This contest and competition of systems is both inevitable and all-important. Unless the new scholasticism were determined to keep closely in touch with living, actual thought, why should it be of the twentieth century any more than of the thirteenth? Or how could it hope to flourish in the face of positivism or of Neo-Kantism unless by vindicating its superiority over them in open intellectual discussion? And if these latter systems do not commence the debate, why should it not take the initiative? Where is the use in being an courant with your age if your work is not noticed by the men of your age : and how are you to attract their notice unless you raise the questions they raise, and in the way they raise them, in order to compare and eontrast system with system, argument with argument? It is amusing to find philosophers at the present day proving against the ancient Greeks that the soul is neither a circle nor any other species of figure, while they remain in blissful ignorance of the agnosticism of a Spencer or the idées-forces of a Fouillée. Here, again, the old-time scholastics are our masters, if we would only learn from them. Thus, St. Augustine breaks a lance not with the ancient mystics of Eleusis, but with the Manicheans who were swarming all the schools of his day; while Alanus of Lille and William of Auvergne address themselves not to the Manicheism of the past, but to the contemporary errors of the Cathari and the Albigenses. So, too, St. Thomas writes against his Averroistic colleague, Siger of Brabant, in the University of Paris ; he loses no opportunity of attacking the theories of the Arabian Averroës and the Jew Avicebron: and if he were to come amongst us to-day 
he would leave Siger, Averroës and Avicebron alone, and join issue with Paulsen, Wundt, Spencer and Boutroux.

This acquaintance with the systems of our adversaries will not only help us to sift the true from the false in what they contain, but will likewise enable the new scholasticism to benefit by many a theory accepted in modern philosophy, to correct its own errors and to make good its own shortcomings. And as to the great leading principles which it will have victoriously defended against modern attacks, how much more mature and reasoned will be our certitude of them, as a result of such serious discussions! Is it not a consoling thing, after all, to have gone the rounds of contemporary thought, and to have found that the explanations others have to offer of the mysteries of life are a much more defective and imperfect lot than the little inheritance of which we ourselves are in possession? Is not that of itself something to reassure us in those hours of darkness when weak human reason grows anxious at the fogs and mists that sometimes overcloud even its most sacred and cherished convictions?

114. All those considerations which we have been putting forward in the present Section would appear then to issue in a conclusion analogous to that of the preceding Section: The reassumption, in the abstract, of a vanished philosophical system, has no need for the history of philosophy; and the little coterie who would adopt it as their credo may put up their library shutters and leave the outer world alone. On the other hand, the accommodation of the new scholasticism to our own time will require a distinct development in historical studies and an advance along the lines laid down by modern historical criticism. 
SeCtion 23. - The NEW SCHOlastic PhILOSOPHY AND RELIGIOUS DOGMA.

115. In this connection the effort to harmonize the new scholasticism with modern thought implies a considerable departure from the medieval point of view. It is not, of course, that we need to establish a distinction between philosophy and religious dogma, Catholic or otherwise: such distinction was already clearly recognised in the Middle Ages (5). The new scholasticism is not a theology ; the former might be entirely renewed, while the latter remained quite stationary and uninfluenced; or vice versa. Indeed, we are just now witnesses to a revolution in theology : but the very remarkable controversies of modern times upon Biblical criticism and the Inspiration of the Scriptures, have little to do with philosophy.

However, the Viddle Iges bound up philosophy with theology in a system of the closest hierarchical relations: the natural outcome of a civilization in which religion held undisputed sway over public as well as private life, and Catholicism enjoyed a monopoly, in fact and in right, throughout the entire Western world. The philosophical curricula of the abbey schools, and afterwards of the faculty of arts in Paris, are both an index and a product of this peculiarly medieval view of things (37).

But religious as well as political continuity has been long since interrupted and broken in society: the outcome of which fact is a more or less complete neutrality of the State towards religions. So also have medieval pedagogic institutions vanishedwith the spirit of which they were the visible embodiment. To attempt a reconstruction of them would be endeavouring to set up a regime whose very foundations have disappeared. And hence such an intermingling of philosophical and theological theses 
and arguments as is characteristic of the thirteenth century Summa, would be entirely out of place and unmeaning in our courses and treatises on modern scholasticism $(37,45)$.

At the present day it is not in connection with theology that the problems of scholasticism arise, and the progress of the latter discipline is in no way dependent on that of the former. Above all, the new scholastic philosophy is autonomous: it has a value of its own, a value that is absolute and independent. In the Middle Ages, over and above that function, philosophy fulfilled the rôle of a guide or introduction to theology. The diploma of doctor in philosophy is nowadays something more than a preparatory step towards degrees in the sacred sciences : it stands on its own merits, and its right to do so is recognised universally. It now invites to its "banquet" not merely those who are destined for the service of the Church in the ranks of the clergy, whether secular or regular, but all, without exception, who have a thirst for knowledge in the better and larger sense of the word. It even gives a special welcome to those who study it for its own sake, without any religious or professional object; and it holds out to all who approach it the promise of knowledge and certitude about crod and the whole universe, about man and man's destiny, and the meaning of human life.

116. But what are we to say of the doctrinal, as distinct from the pedagogical, relations established in the Middle Ages between philosophy and theology? For if extra-doctrinal relations are dependent on circumstances of time and place, surely the doctrinal relations themselves are above and beyond all such conditions? Must these, therefore, remain unaltered in the scholasticism of the twentieth century? If we are correctly gauging the attitude of contemporary scholastics on this matter, we believe there is nothing 
to change on the side of philosophy. The independence of modern scholasticism in relation to all theology, as in relation to all other sciences whatever, is simply an interpretation of that unquestionable principle of scientific progress, as applicable in the twentieth century as it was in the thirteenth: that a properly constituted science derives its formal object, its principles and its constructice method. exclusicely from its own domain; and that in these things, any borrowing from another science would compromise its very right to a separate existence (j).

The material subordination of the various sciences amongst themselves is a law that is logically indispensible for the unification of human knowledge. "A truth that has been duly demonstrated as certain in any one science will serve as a beacon to all other sciences." A theory that is certain in chemistry must be accepted in physics: the physicist who runs counter to it is surely on a false track. In like manner, the philosopher may not endeavour to upset the certain data of theologs any more than the certain conclusions of the particular sciences. This reasoning, which we find formulated by Henry of Ghent, is as sound and cogent to-day as it has ever been. The manifold forms of scientific activity are regulated and limited by a mutual subordination of branches, which is, however, negative and prohibitive, not positive and imperative. To deny such mutual limitations would be denying the conformity of truth with truth: it would be denying the principle of contradiction, and vielding to a relativism destructive of all knowledge (38).'

$\left[{ }^{1}\right.$ Hence a philosophy is untrue in so far as it contradicts Revealed Truth; and he alone possesses the fulness of truth-so far as it can be had in this world-who possesses the Christian Philosophy of Life, that Philosophy which embraces and harmonizes natural and revealed truth. As we have written elsewhere in this connection: "However systems may differ there is only one true Philosophy of Life, varied and manifold as its expressions may be. Life has its departments of thought and of action; but these, though distinct, are related. 
But when is a theory certain? Here is a question of fact, in which it is easy to make mistakes. In proportion as the principle is simple and absolute, its applications would seem to be complex and variable. It is no more the philosopher's business to vindicate the certainty of theological data than of the conclusions of physics or chemistry. On these matters he must look for certitude elsewhere: and so long as it is not to be found he need take little notice of such data or conclusions.

117. From the point of view of philosophy pure and simple, so far is Catholicism from being inseparably bound up with the new scholasticism that during the last century philosophers have been endeavouring, in the very best faith, to adapt the most varied and widely divergent systems of philosophy to the teachings of Christianity-and so we see repeated once more a phenomenon which was observed taking place in the Middle Ages, at the Renaissance, and during the formation and development of the numerous systems of modern philosophy (43, $4 t h$ reason). Several such examples will be easily recalled: Gunther's Dualism, now forgotten, but only after a long spell of popularity in Germany and Austria owing to its unmistakable tinge of Hegelianism; Rosmini's philosophy in Italy, founded by one who was a saintly priest though an unsafe psychologist, and which can still count numerous sincere disciples ; ${ }^{1}$ Traditionalism, so ably defended by De Bonald and Bautain; Ontologism, which has had no living voice to

The true and the good are standards in all, whether in Nature or above it. If man's mind and heart conform to them fully, he is a philosopher and a Catholic. In so far as he deviates, he falls into error and evil If his philosophy is out of harmony with Revealed Truth, it stands convicted of error. The man who loves truth and seeks it will embrace a philosophy that makes room for Revelation and recognises on earth an Infallible Exponent of that divine message to mankind."-Thoughts on Philosophy and Religion, in the Irish Ecclesiastical Record, May, 1906, p. 388. $-T r$.]

1 The organ of Rosminianism is the periodical Il Nuovo Risorgimento, edited by the irascible Mr. Billia. 
plead for it since the death of Professor Ubaghs of the University of Louvain : and, finally and especially, the Cousinian, eclectic Spiritualism which has so long been the "official philosophy" of France, and which is even still to be met with in so many of its seminaries: between all these systems and scholasticism, whether ancient or modern. there are very profound differences, and nevertheless the supporters of these systems were good catholics. "Associated with the names of Descartes. Malebranche. Leibnitz. Balmes, Rosmini, ote. [these doctrines and theories] became as familiar to the new. as pure scholasticism had been to the older generations. It was a sort of eclecticism, not rery decep, or systematic. or strong: ret it was truly a Christian philosophy. loyal to the faith and to the ('hurch: and helped, like the theories it superseded. to light up the obscurities of revealed truth, to defend its doctrines, and to establish peace between reason and faith.".

The most interesting of those attempts to square a given philosophical system with Catholicism is that which is now being actually made by a group of French catholics - not merely lar, but celerical-who

${ }^{1}$ Hogan, wf. it., 1). 3s. The anthor remarlis that "one of the most eloquent panegyrics crer written on Inescartes" came from the pen of a Jesuit, Fr. Guenard (ibid., p. 5i).

[Neither to the quotation in the text above, nor to the paragraphs illustrated by it, can any reasonable exception be taken; for they fully recognize the mativial dependence of philosophy on theology, and imply that no theory or system can be true if it contradicts any doctrine estallished as cortainly true by theology. They do not, however, make it quite clear how far the abovementioned systems, or any of them, have a right to be called " Catholic," or to be described as "Christian Philosophy." 'The anthor's views on the relation of Philosophy to Religion and supernatural Theology, his apparent denial (cf. below, p. I $j$ ) that Catholicism can be exclusively and inseparably bound up with any one system of philosophy (and his alleged definition of scholastic I'hilosophy by its content alone, exclusive of its metho(l) have been adversely criticized in the EtudesFranciscaines (October, 1904, p1). 338-355; March, 1905, pp. 270, seq. Libcralisme philosophique: I propos d'un livere recent) by Père DiégoJoweph, and defended in the same Review (January, I905, pp. 36-54.Reponse au "Libéralisme philosothique") by Pére Hadelin.-Cf. p. 192, footnote. $-T r$.] 
are enthusiastic supporters of Neo-Kantism. The movement is of recent date, and is making rapid progress. Its significance is all the greater because it shares the many attractions of a well-known, widespread and fashionable philosophy; and also because it is contemporary with an almost universal coalition of Catholic philosophers-mainly of priests and religious - who profess and advocate allegiance to a modern scholasticism.

The intellectual dictatorship of Kant is nowadays officially proclaimed and acknowledged in most universities, especially in France and Germany. From the calm heights of pure speculation, which are familiar to the philosopher alone, Kant's teaching and theories have also found their way into the prefaces of scientific works and into avowedly popularizing treatises; nay, they have even percolated into our modern dramas and romances. ${ }^{1}$ We believe that the explanation of the enormous influence of Kantism lies in its remarkable combination of a theoretical subjectivism with a practical dogmatism. The phenomenism which is the last word of the Critique of Pure Reason, and which Bergson has pushed to its logical extremes, would never have caught on without the noumenism of the Critique of Practical Reason. Kant's ethics serve as a palliative after his criteriology, for they establish, on the basis of sentiment and will, the existence of God and of the soul, as well as human liberty and immortality: all of which realities or things-in-themselves the intelligence of man is unable to discover, and which are, nevertheless, the indispensable nourishment of moral and social life. Hence, we see, it was mainly on the ground of his ethical teaching that the

1 Witness the Déracinées of Maurice Barrès, and more especially the Nouvelle Idole of François De Curel. This piece, played some years ago at the Antoine theatre in Paris and the Molière theatre in Brussels, contains some curious and characteristic assertions of agnosticism and Neo-Kantian voluntarism. 
"return" movement "towards Kant" ("Zuruck $z u$ Kant") was accomplished. But is there any real possibility of good companionship between the mutilated certitude of a reason that rules a world of mere representations and the certitude of a will that goes deeper down into another world of extramental realities? Is it a logical theory, this of the two certitudes? We doubt it gravely, and that for reasons of a purely philosophical kind: this, however, is not the question to settle here.

Suffice it to remark that this "voluntarism" will allow a Catholic, who accepts the two antinomian certitudes of Kantism, to holl that the objective data on which the Catholic faith is based are illusory in the face of pure reason, and at the same time to hold their reality and affirm their real existence through and for the will.

And there are, in fact, Catholic Neo-Kantians. Olle-Laprune, with his sentimental philosophy, may be said to have prepared the way for them. "Even philosophical knowledge, even rational certitude is not a product of the pure understanding, of the pure reason. Belief is an integral element of science, just as science is an integral element of belief; that is to say, that the life of the spirit is always one and continuous with the life of the being himself; or again, that philosophy is indissolubly a matter both of reason and of soul; or again, finally, that thought can neither suffice for life, nor can life find in itself alone its light, its strength and its whole law. "We must discern more than reason in man, and more than man in reason.", M. Blondel, who sums up in those words the teaching of Ollé-Laprune, ${ }^{1}$ has himself improved on his master; and others have followed these-in a direction leading straight to Neo-Kantism. Indeed, to arrive there nothing more was required than to bring Ollé-Laprune's

\footnotetext{
'M. Blondel, Léon Ollé-Laprune (Paris, 1899).
} 
attack on reason into explicit conformity with the Kantian criticism, and to confine all certitude about the real world to man's volitional activity.

On this peculiar attitude of certain French Catholics the reader will find copious bibliographical information combined with some suggestive comments, in an exhaustive article published in the Kantstudiena periodical which keeps thoroughly abreast of the evolution of Kantism. "Notwithstanding the Encyclical of the 4th of August, 1879, which describes Christian philosophy as scholastic," writes M. Leclère, " and the Encyclical of the 8th of September, 1899, condemning Kantism, there are-in this land of France where the faithful are usually so prompt to hearken to the voice of the Holy See-Catholics and even priests, who have consciously or unconsciously drawn their inspiration from Kant, and continue to do so, in the hope of building up in this wise a new philosophy that may serve as a human basis for revealed faith; and they contend that they are as free from heresy as the Thomists who are opposing them, or the Cartesians who are left quietly alone." 1

118. Let us, therefore, freely accept the conclusion that a Catholic may, in good faith, give his allegiance to systems other than the new scholasticism. ${ }^{2}$

I Albert Leclère, Le mouvement Catholique Fantien en France a l'heure présente (Kantstudien, Bd. VII., H. 2 and 3). "Reprint, I902, p. 2.

${ }^{2}$ [This, of course, does not in any way imply that conflicting systems may be true together; nor is it in any way incompatible with what has been said above regarding that matter (See footnote, p. I94). A Catholic may adhere, in good faith, to a system that is on the whole unsound. I have elsewhere gone "so far as to say that if by different philosophical systems are meant presentations and combinations of the same general truth looked at from different points of view, then you can have a number of such systems in accord with Revelation.

Hence the answer to the interesting question how far Catholics may adhere to different schools or systems of philosophy will depend very largely on the view taken as to the meaning of a 'school ' or a 'system.' In so far as these are merely different expressions or presentations of the same natural truths from different standpoints they are in necessary harmony with Revealed Truth, and a Catholic is free to choose. But in so far as they are contradictory of each other, some of them must be erroneous, and such error may' be in logical opposition 
This being so, it is clear that there can be no sueh thing as a Catholic philosophy any more than there can be a C'utholic science. "But there are philosophers who in the matter of religion profess definite dogmatic beliefs, just as there are chemists or medical doctors who are at the same time catholies. or Protestants. or Jews. Modern scholasticiom will progress and develop without meddling in any way with matter's of religion: it wonld be a fatal hilunder to confound it with apologetics."

The following paragraph. taken from one of the most rminent leader's of the new scholastic movement, sets forth dearly and forcibly the proper attitude for cathelie scientisto to talio up as ab safegmard and pledger of freedom in their scientifie: speculations :

". . . the false notion is absoat? that the catholie. sarant is always and necessarily defending his faith.

Elirectly or inclirectly-to sone revealed truth; and if it be, junt as no philosoplier shonlel adhere to it if he saw its erroncons character. so also no (atholic should allhere to it if he saw its opposition to Revelation. But a Catholic may see neither the error nor the opposition in question; and, so long as he does not, he may adhere to the system without seemg the logical inconsistency of his position. III the more so, as he may in good faitl interpret Revelation in a sense which he regards as true, and which is de facto consistent with his philosophical views. But all that will not make these latter any hese erroneous or any less opposed to the true meaning of the Revealed Truth in question. St. Augustine, Scotns, Eringena, Alelard, st. Thomas, 1)nns Scotıs, William of Occam. Nicholas of Cusa, Descartes, Gassendi, Malebranche. Pascal, Rosmini, were all alike Catholics; but is that any proof that their philosophical systems, which difterer so widlely, were all substantially true or substantially orthodox, or that some of those mentioned dic not remain Catholics rather in spite of their philosophy, so to speak, and through bona-fide ignorance of the unsonndness of their systems?"-I. L. Record, art. cit., Pl) 387-3s, - Cf. above p. 74.-Tr.]

'[This is quite true, and quite consistent with the negative and material subordination of philosophy to theology insisted on above (p. I92); as also with the fact that there can be only one true Philosophy in the larger sense of a Philosophy of Life. (See footnote, p. 162). - Tr.

- Biblical criticism and scientific cliscoveries of all sorts have given a considerable impetus to modern apologetics. In fact, they have practically made it a new science: unlike medieval apologetics, it appeals not merely to philosophy but to all the special sciences. Even in the Midlle Ages, however, philosophy proper was distinguished from dialectic or aprlogetic philosoply (39): a distinction that is more important nowadays than it ever has been. 
that in his hands science must needs be a weapon to be utilized for that sole purpose. Indeed, not a few are disposed to regard the Catholic savant as living in constant dread of the thunderbolt of an excommunication, as bound hand and foot by distressing and cramping dogmas, as utterly unable either to profess or to feel a disinterested love for science, or to pursue it for its own sake, so long as he remains faithful to his religion. Hence the distrust he encounters on all sides. A publication issuing from a Catholic institution-Protestant ones are received with less disfavour, doubtless because they are regarded as having given some proof of their independence by their revolt from authorityis almost invariably treated as a plea pro domo, a one-sided, apologetic affair, to be refused-a priorithe right of an impartial, objective examination." 1 "We must aim at forming, in greater numbers, men who will devote themselves to science for its own sake, without any other or remoter aim of a professional or apologetical character, men who will work at first hand in fashioning the materials of the edifice of science, and so make original contributions towards its gradual construction." "

It would be an utter mistake to imagine that the new scholasticism was called into existence to do battle for any religious belief; or to imagine with M. Picavet, for example, that "Catholics, identifying it with Thomism . . . contend that it has the same value for them as it had for the orthodox Thomists of the thirteenth century." 3

1 Mercier, Rapport sur les Ĺtudes superieures de philosophie, presented to the Congress of Malines, September 9 th, I891, p. 9.

I Ibid., p. I 7.

3 Picavet, in the Grande Encyclopédie, under the word "scolastique" (last paragraph). 
SeCtion 24. -THE NEW SCHOLASTICISM AND THE MODERN SCIENCES.

119. The history of the sciences during the last three centuries, especially during the nineteenth, is like the tale of one grand triumphal march of the human mind. In the domain of visible Nature, the inductive methods have led to astonishing discoveriesdiscoveries that have made the world of the twentieth century almost another world altogether from that of the Middle Ages; and Nature is being forced to vield up more of her secrets every day.

From the standpoint of method, or the general logic of the seiences, three profound differences mark off the moderin from the medieval epoch : the multiplication of the sciences; their separation from philosophy; and the distinction between common or ordinary knowledge-cognitio vulgaris-and scientific. knowledge.

In the Middle Ages astronomy bordered on astrology, chemistry on alchemy, and physics on magic; in our days science has ruthlessly eliminated whatever is groundless or fanciful. By sifting and searching the nature of corporeal things in every conceivable way, new aspects of matter have been revealed in rapid succession, and each distinct point of view has become the centre and starting-point of a new branch of scientific study. This multiplication of the sciences has gone hand in hand with a more careful and exact determination of their respective boundaries: to take a few examples at random, we see that crystallography, stereochemistry, cellular biology, bacteriology, are confined each within the sphere of a perfectly definite "formal object," which we might describe as the typical angle at which each of them approaches the study of a more or less considerable group of things. 
By thus determining their respective boundaries the sciences secured for themselves an autonomous power, and thus loosened the ties which had hitherto bound them so closely to philosophy. In the Middle Ages they were considered as mere preliminaries to the study of rational physics $(48,49)$; specialized research had no meaning except as a preparation for the synthetic process of philosophy. To-day the sciences have a meaning and a value of their own : each has its own work cut out for it; and their separation from philosophy is complete. Unfortunately, the impetus of extreme and prejudiced notions has exaggerated that friendly, mutual independence into a hostile divorce; the scientists have gone one way, the philosophers another; and the disastrous old prejudice has too readily taken roota prejudice so unjust, untrue, and injurious to all branches of knowledge that the results furnished by the work of the one party are incompatible with those yielded by the labours of the other.

The progress of each special science within its own domain has wrought yet another revolution in human knowledge. Until mechanical instruments for the accurate and detailed observation of phenomena were forthcoming, inductive methods were necessarily restricted in their application; and it was, as a rule, impossible to get beyond a very elementary knowledge of the workings of Nature. It was well known in the thirteenth century, for example, that wine exposed to the air became vinegar. But what is such knowledge compared with the complex formulas of modern chemistry? In those ages Albert the Great or Roger Bacon might boast of having mastered all the sciences of their time; nowadays any such pretension would provoke a smile. In every single branch, progress has compelled the distinction between common and scientific knowledge. The former is usually the starting-point 
for the latter: but the teaching and conclusions: of the various sciences can be fully understood only after a lome and laborious process of initiation in the case of each and evert one of them.

120. 1)o those profound changes in the ontlines and contents of the sciences imply a corresponding change in the relations established in the lliddle Ages between science and philosophy, in the attitude of each order of studies towards the other? Will modern seholasticism pay no hered to the discoveries of those sciences, or will it rather draw its inspriration from those discoveries?

There should be no mistaking the principlo underlying the answer to such a question. The eonsiderations that ureed medieval scholasticism to keep) in touch with the seiences are a thousand times more cogent nowadass than ever they were. If the deep and all-embracing view that justifies ihe separate existence of philosophy (48) presmploses analytio researches, is it because these latter have been multiplied exceedingly that we are to begin to ignore them ? ${ }^{1}$ The horizon of specialized lnowledge is

1 "All that exists, as contemplated le the human minel, forms on" large'sytem or complex fact. . . . Now, it is not wonderful that, with all its capabilities, the human mind cannot take in this whole vast fact at a single glance, or gain possession of it at once. Like a short-sighted reader, its eye pores closely, and travels slowly, over the awful volume which lies open for its inspection. Or again, as we deal with some huge structure of many parts and sides, the mind goes round about it, noting down, first one thing, then another, as best it may, and viewing it under different aspects, by way of making progress towarks mastering the whole. . . . These various partial views or abstractions . . . are called sciences . . . . they proceed on the principle of a division of labour. . . . As they ail belong to one and the same circle of objects, they are one and all connected together; as they are but aspects of things, they are severally incomplete in their relation to the things themselves, though complete in their own idea and for their own respective purposes; on both accounts they at once need and subserve each other. And further, the comprehension of the bearings of one science on another, and the use of each to each, and the location and limitation and adjustment and (iue appreciation of them all, with one another, this belongs, I conceive, to a sort of science distinct from all of them, and in some sense, a science of sciences, which is my own conception of what is meant by philosophy. . . ." Newman, Idec of a Lniversity : I)iscourse III., 3, 4 (PP. $4+5-5$ I). 
ever receding; all sorts of researches have parcelled out between them the various departments of the visible universe: and is it that philosophy, whose very mission is to explain that universal order by its highest and widest principles-by principles applying not merely to this or that particular group of facts but to the totality of known phenomenashould be unconcerned about the very thing to be explained! Philosophy is like a watch-tower from which we gaze out upon the panorama of some stately city. We take in its general outline, the great arteries of its commercial life, its main streets and public places, its most striking monuments, their general appearance and relative positions: in a word, all the many things that a passing visitor fails to see, who merely walks through its streets and laneways, or visits its libraries, churches, galleries and museums. But what if the city gradually grows and stretches away into the dim distance? Why, evidently all the more reason-if we would still secure a bird's-eye-view of it-to ascend, and, if needs be, to build, still higher, the steps of our tower, and so be able to discern the general plan and the main, outstanding features of the more modern quarters.

Moreover, the new scholasticism is heir to certain theories in explanation of the cosmic order; and those theories it holds to be as valid and as fruitful at the present day as they were in the days of Aristotle or of St. Thomas, while its opponents declare them to be irreconcilable with the conclusions of modern science. Would it then be wise or opportune to withdraw those principles from the shock of an encounter with current difficulties and from the test of a comparison with the established truths of science, as the weak and the feeble are wont to be sheltered from trying conflicts? Of two things, one or other: Either the old principles are powerless 
to interpret and assimilate the established data of the modern sciences, in which case modern scholastics -secking truth above all things, as they do-will no longer allow mere chimeras to lull them to a false security. Or those old principles will not yield an inch to the systems invented by modern philosophers, but will adapt themselves equally well to the new facts and furmish an equally satisfactory interpretation of them: in which case the philosophy of the past will have come out victoriously from the contest and established a rightful claim to be likewise the philosophy of the present. That is exactly the reason why the wedding of philosophy to the sciences is not merely one of the striling features of the present scholastic revival, but even the principal aim of the promoters and pioneers of the movement. The principle was elearly and explicitly laid down by Jeo XIII. in the Enevelical Eterni Patris; and the Louvain Philosophical Institute, founded by his orders, has consistently carried out its application in every department of its teaching.

1.21. It would be almost impossible to enumerate the men of note who have lent their warm support to this programme, or to give even a faint outline of the arguments they bring forward in favour of it. Two books, chosen at random from a number, will supply copious information to those who are interested in the very actual question of the reconciliation of philosophy with the sciences; the one, historical: La philosophie de la nature chez les anciens," by M. Ch. Huit; the other, more theoretical: Contribution philosophique a l'étude des sciences, ${ }^{3}$ by Canon Didiot of the Catholie Faculty of Lille.

Then, moreover, the necessity of a scientific

[See Appendix - Tr.]

" Paris, igoi. Crowned by the French Acalemy of Moral and Political Sciences.

${ }^{3}$ Lille, rooz. Cf. Bannard, Th siècle de Eglise de France, i 902, Ch. "Etudes divines et humaines." 
philosophy is admitted everywhere at the present day, not merely by modern scholastics but by all the leaders of thought in the most widely divergent schools of philosophy. M. Boutroux, for example, is constantly insisting on the importance of a good understanding between philosophers and scientists. We have all the more pleasure in quoting some statements of the learned. Sorbonne professor, recently made at a few Philosophical Congresses, because they amount to an emphatic expression of Aristotelian and scholastic teaching. "Such a union," he said, "is in fact the classic tradition of philosophy. But there came a psychology and a metaphysics with the claim that they could exist and develop independently of the sciences by drawing their nourishment from the self-conscious reflexion of the human mind. To-day, however, philosophers are all at one in taking scientific data for their startingpoint." Of course; for the essential function of philosophy is to harmonize and unify in some higher synthesis the things that are given to us as separate. "Side by side with the analytical researches in which the positive sciences are almost exclusively concerned, there must be another order of researches wherein the mind will examine, in things, the conditions of their intelligibility, iruth, harmony and perfection. Logic, Psychology, Noral should faithfully preserve within them the leaven of Metaphysics, which will some day perhaps take up current experimental theories and breathe a

These reflections on the state and scope of philosophy will help to determine the aim and method of philosophical teaching in our universities. Such teaching ought to have both a universal and a special character. In fact, what is peculiar to such training, and what

1 Opening discourse at the International Congress of Philosophy, organized in 1900 by the Revue de métaphysique et de morale.- See same Review, Sepcember, I900, p. 697. 
differentiates it from all other mental disciplines, is just this feature of universality. It aims at embracing things and scienees. theory and practice, concrete and abstract, real and ideal, matter and mind, both in their immer mutual relations and in their underlying unity. To accomplish this task. it must have comstant recourse to the positive seiencess and it must likewise anstantly refresh itself with reflex thought."

Professon Ilundt of Leriprig. Whose exerptional competence in soience and philosophy adds great weight to his anthority, is of the same way of thinking. one particular batrogaph in his Eimleitumg in die Philosophe' where ho deals re profosese with the present question, andules with this sionificant definition of philosephy : " Philosophy is the general science whose function is to unify in one comsistent system all the knowledere brought to light by means of the sereral special seiences. and to trace back to their first principles the methods in common use in those sciences and the conditions which they in common assume as prerequisites to all knowledge." 3 Yet another well-known scientist of Leiprig. Ostwald, professor of chemistry, writes in an introductory article in the Annalen der Naturphilosophie, that under his editorship the review will aim at " exploring the territory that is common to philosophy and the special sciences." Finally, we may quote these interesting words of Professor Rhiel: ". Never in the history of science," he writes, "was there an epoch more given to philosophy than the present one.

1 International Congress on Higher Education, I9oo, in the Revuc anternationale di l'cuscigncment. I)eember I5. 1901, Pp. 507-509.

- Leipzig, roor.

"Section 2, Philosophic und Itisscnschaft: "Philosophie ist die allgeneine Wis-nschaft, welche die durch die Einzelwissenschaften vermittelten Erkentnisse zu einem widerspruchlosen System zu vereinigen, und die von der Wissenschaft benützten allgemeinen Viethoden und Voraussetzungen des Erkennens auf ihre Principien zurikzufiihren hast" (p. IQ). 
For we are now coming to see the value and the significance of the inevitable division of labour that has forced itself upon us. . . . This is the age of 'synthetic science,' and synthesis is synonymous with philosophy."'

122. The reader will have to pardon us for giving such lengthy quotations. They are needed in view of the attitude of those lovers of tradition who are unrelenting adversaries of everything modern: the testimony of such unimpeachable witnesses as we have just mentioned, in favour of a philosophy based on the sciences, ought to set those people thinking. Laudatores temporis acti, tenaciously conservative of the past, they wish to know nothing about what is going on around them, because they imagine that it is all simply and solely an attack upon their fortress of truth. Vetera is their motto: paleo-scholastic their name. When we remember that some of them have suggested that the Almighty may have created the fossils in the state in which the geologists have found them, we cannot well refrain from a sceptical smile. ${ }^{2}$ The fact is, these men live amid their contemporaries, indeed, but are certainly not of them; to give samples of their out-of-date knowledge would not be worth the trouble. We shall be better employed examining some of the reasons by which they seek to justify their voluntary ignorance of science. Those reasons are partly of a theoretical, partly of a practical kind.

Ordinary observation, they say, yields an adequate foundation for philosophy. This is proved by the very existence of scholasticism. Seeing that the Middle Ages have been able to rear such an imposing edifice of synthetic thought without the aid of modern scientific theories, why should we now have recourse

'A. Rhiel, Zur Einführung in die Philosophic dev Gegenwart (Leipzig, 1902), p. 247.

"Cf. Besse, op. cit., p. 32. 
to these latter for the reconstruction of that same edifice?

Yes, of course, even ordinary superficial observation is usually trustworthy in its informations: and it will accordingly furnish sound materials for abstract philosophical thought. Otherwise how would the ancients have ever known anything at all about the philosophy of Nature? But that is not the question here. The question is whether ordinary observation will suffice always and everywhere. Or are there not whole regions of things quite inaceessible to common, unaided experience? And can the philosopher remain altogether indifferent to these? Such questions must be almost superfluous : to ask them is to answer them. Has not biology let in a flood of light on the philosophical study of human nature ; and have not chemistry and crystallography done the same for that of inorwanic nature? " Would it be wise," asks Professor Nys, " to eondemn ourselves to use indefinitely the primitive utensils of our ancestors, for the sole reason that they had no better for their purposes in their day ? . . . . All visible nature is nowadays revealed to our gaze in quite a new light. Why should the philosopher not take advantage of this newly known world and interrogate and explore it for his own special purpose?" 1 So truly has every new phenomenon its philosophical side that "there is not at the present day, in the study of visible nature, a single branch that is not crowned with some philosophical hypothesis or other." * More than this. It is just one of those hypotheses -and one that is seriously entertained-which now calls into question the very foundations of that common observation on which our old-time scholastics are still fain to build: the hypothesis that denies all specific distinction between the various properties

1 Nys, Cosmologie (Louvain, 1903), p. 23.

Ibid., P. 2 . 
of corporeal things. Modern atomism would reduce all those properties to mere movements of one homogeneous matter. And there is little use in trying to answer its arguments by a mere appeal to ordinary common sense or to a long-standing tradition. For better or worse the question has been pushed back, by an analysis of both common sense and tradition, to the domain of science, and either there or nowhere must it be answered.'

123. Besides this theoretical objection, difficulties of the practical order have been urged against the realization of the new scholastic programme. The special sciences are so extensive, and their growth in recent times has been so rapid, that no individual philosopher can hope even to reconnoitre those vast regions, much less to master them. "Science," in the Aristotelian sense of the word, is become an Utopia, an ideal not given to mortal to realize.

We will let one of the ablest promoters of the new scholasticism answer that objection. "At the present day," writes Mgr. [now Cardinal] Mercier, "when the sciences have become so vast and so numerous, how are we to achieve the double task of keeping au courant with all of them, and of synthesizing their results? The difficulty is in truth a serious one, nor is it in the power of any one individual to surmount it. His courage will fail and his unaided effort count for little in presence of the daily widening field of observation. And therefore it is that the association must make up for the insufficiency of the isolated individual; that men of analysis and men of synthesis must come together and form, by their daily intercourse and united action, an atmosphere suited to the harmonious and equal development both of science and of philosophy.",

But, then, if all philosophy presupposes a knowledge

1 Ibid., p. 25.

2 La philosophie néo-scolastique (Revue Neo-Scolastique, 1894, p. I7). [Cf. Appendix, infra.-Tr.] 
of the sciences, and if on the other hand it is utopian to aim at knowing all the sciences in detail, where are we to draw the line? Then, too, among those who want to unite the study of scholastie philosophy with the study of the modern sciences, very few are likely to become gemuime research students in the scientific domain: most of them will be satisfied to take their scientific conclusions on the anthority of other's.

This must be admitted muless special scientific courses are provided for students of philosophy. All the necessities of the case can be met only by some such special arrangement. For, the general scientific courses in our modern universities contain either too much or too little for students of philosophy : "too much, because the professional scientific training which they provide must go into a multiplicity of technical details that are not needed for the study of philosophy : too little, inasmuch as the observation of facts is often the ultimate aim of professional training, whereas from the point of view of philosophy it can he only a maans, a starting-point towards the discovery of their highest laws and causes."

II. Boutroux holds the same views upon the teaching of philosophy in miversities: a wide and elastic organization of the philosophical faculty should find a place within it for " all the theoretical, mathematicophysical and philologico-historical sciences."2 Such special teaching as M. Boutroux advocates, and for the same reasons, has been available-and availed of ${ }^{3}$-for the past fifteen years at the Philosophical Institute of Louvain University.4

1 Mercier, Rapport sur los tudes supericures de philosophie, p. 25. (Louvain, Is'g1).

= L'Enetianoment de la philosuphic. Communicated to the International congresi on Higher Elutation, 1000 ) (Revile internat. de l'enseign., I9ui, p. 510.

"Lee Ippendix, infra.-Tr.1

4 To yet another objection, that the instability and imperfection of the sciences do not as yet guarantee us in attempting to base a system of philosophy on them, see the answer given hy M. Besse, ippentix, infra.-Tr.] 


\section{CHAPTER II. \\ THE DOCTRINES OF THE NEW
SCHOLASTICISM.}

SeCtion 25.-DOCTRINAL innovations.

124. The thoughts to which we have been so far giving expression will reveal the sense in which modern scholasticism aims at submitting the great, leading principles of medieval scholasticism to the control of the latest results of scientific progress. The application of this test has modified the doctrinal content of the new scholasticism so far that we may distinguish it from its medieval ancestor: theories now known to have been false are simply ABANDONED; the great, constitutive doctrines of the medieval system are RETAINED, but only after having successfully stood the double test of comparison with the conclusions of present-day science and with the teachings of contemporary systems of philosophy; new facts have been brought to light, and under their influence a store of new ideas has ENRICHED the patrimony of the ancient scholasticism.

125. In the first place, a single stroke of the pickaxe has stripped the walls of the old scholastic edifice of a whole pile of decayed and mouldering plaster : theories transparently false, inspired by erroneous astronomical physics and applied to the interpretation of Nature $(77,78)$, and in which arbitrary observations of phenomena were connected by bonds no less arbitrary with cosmological or metaphysical 
principles. Only a fool would nowadays maintain the relative superiority of the substance of the stars compared with that of the earth. Their incorruptibility, their substantial individuality, their peculiar mode of composition from matter and form, their subjection to extrinsic spiritual movers, their influence on the generation of certain forms of mundane life : these are some of the theories defended by St. Thomas but repudiated by all modern scholastics. The same applies to numerous theories in "terrestrial physics." such as that of the locus naturalis, and that of the four chemically simple bodies with their sets of properties (79); and also to numerous views peculiar to medieval psychology, such as the transmission of "species sensibiles" through space, and their reception into the sense organs ( 87 ).

Still more of those old scholastic theories, especially in the domain of visible nature, are likely to become discredited according as modern science proves their insufficiency. Our own friend and colleague, Professor Nys, has shown clearly, for example, that experiments in the vivisection of the higher kinds of organisms compel us to extend our teaching as to the divisibility of essential forms to all the animating principles in the animal kingdom, and so to abandon the Thomistic theory on the essential simplicity of the higher forms of organic life. ${ }^{1}$

Then, finally, it is plain that of the vast body of doctrines that are certain to survive scientific tests, all are not of equal importance. Nowadays, just as in the Middle Ages, there are views and opinions which open discussion or personal convictions are free to introduce or not to introduce into the new scholasticism, without in any way interfering with its broad and distinctive principles (31).

126. This work of renovation and reconstruction

: Nys, La dirisibilité des formes essentielles (Revue Néo-Scolastique, 1902, p. 47.) 
will show forth the main lines of the edifice and give scope for the application of new designs. The organic principles of the system undergoing restoration must unquestionably form the basis of the new scholasticism. But let there be no mistake about the scope of the contemplated restoration. It will not be brought about insensibly or unconsciously: it will not be merely mechanical or merely a priori. Here, above all, it behoves us to form well-reasoned convictions, based on long and ripe reflection. The new scholasticism must assert and make good its claim to live; and for that it must stand the test of comparison with rival systems (113) and of agreement with scientific conclusions (120). The matter and form theory is an explanation of cosmic change ; but it will not survive the twentieth century unless it compares favourably with mechanical atomism and with dynamism, both of which hypotheses claim to have discovered the true meaning of the facts. Scholastic spiritualism and scholastic ideology offer an interpretation of the facts of consciousness and an explanation of the difference between sensation and thought; but they must also show us that the explanation offered by the positivists is not any better supported by the results of modern scientific research. The Middle Ages propounded doctrines of the most purely idealistic character regarding happiness and the last end of man; but perhaps the utilitarianism of the positivists, or the formalism of Kant, or the pessimism of Schopenhauer, have shown those ideals to be chimerical? Finally, metaphysics was regarded as the perfection and completion of knowledge in the schools of other days; nowadays, its very possibility is called into question. Which is in the right, the past or the present? It is important that we should know.

127. Each epoch in philosophy reveals a mental attitude all its own; its favourite occupations 
disappear to give place to new pursuits in the next epoch. Ancient India devoted most of its speculation to the monistic blending of all things in the region of the real. Greek philosophy made the relation of the one to the manifold, of the changeable to the stable. the chief engrossing subject of all its meditations and discussions. The problems which concern us to-day are not exactly those that oceupied the attention of our great-grandfathers. The lapse of a hundred years-three gencrations of mortalshas intreduced a very radical difference between the society of 1789 and that in which we live. Were a writer of the eighteenth century to reappear amongst us to-day he would be as hopelessly bewildered br current philesophical thought as a labourer of the Empire would be if suddenly dropped down into a modern factory.

So also, the peculiar genius of the Middle Ages will be no longer found in the twentieth century. The mind of the thirteenth century betraved a peculiar penchent for metaphysical and psychological investigations - for metaphysics especially - which represented the culminating point of human knowledge, as being the product of the highest effort of abstract human thought (49). In fact, certain metaphysical questions had such an all-absorbing interest for the thirteenth century philosophers that they turned up at almost every point in the discussions of the schools: such, for example, the principle of individuation, the multiplicity of individuals in the same angelic species, the questions about essence and existence, about nature and suppositum, about matter and form. Like all the more remarkable and fertile epochs in philosophic thought, the thirteenth century devoted special attention to problems connected with the study of man. But its psychology was influenced by the metaphysical tendencies of the time: it showed a decided 
preference for questions in rational psychology, because these are for the most part closely allied with ontology. Thus, for instance, the problem of the origin of ideas, involving the theory of the two intellects, is connected with the ontological doctrine on actio and passio (89); the distinction between the soul and its faculties, particularly between intellect and will, is attached to the metaphysical teaching about operative power in contingent being (85).

In recent times, on the other hand, two entirely new and original tendencies have asserted themselves in the treatment of all such problems: towards positivism and towards criticism. The great dogma of positivism - the positivity, so to speak, of all human knowledge-would limit the knowable to the experimentable. This thesis, notwithstanding the error it contains when formulated in such exclusive terms, has taught contemporary philosophy to pay the most scrupulous attention to all facts, and more particularly to those that lie on the confines of philosophy and the natural sciences. An emphatic inculcation of the importance of observation, internal and external, is the outcome of the tendency in question. Psychology is the department of contemporary philosophy in which it has received its fullest application. There, experimental methods of procedure have been employed in the investigation of conscious and subconscious states, in studying the neural concomitant of psychic phenomena, and sensational and emotional life generally.

Still more marked and widespread is the critical tendency, introduced by Kant into modern philosophy. Before trusting to any natural cognitive endowment whatever, Kant raised this previous question: does the structure of our faculties render at all possible the application of our knowledge to an extra-mental world? And we know how the Critique of Pure Reason enshrouded all our specu- 
lative convictions one after another in subjectivism. If we are to believe Kant, the object of our knowledge is a represented world and not a world-in-itself; for no thing-in-itself is knowable. The genius of Kant has cloven a twofold furrow in contemporary philosophical thought.

In the first place, he has been the direct inspiration of all subsequent systems of "critical" and "neocritical " philosophy, both in the direction of transcendental idealism and of transcendental realism. The idealists - of the type of Fichte and Hegelreduce all knowledge to a sort of mental poem, a product of a priori forms, and pronounce the thingin-itself to be not merely unknowable, but simply non-existent. Realists on the other hand, like Schopenhauer or Herbart for example, admit the single fact of the existence of an unknowable, but persist in knowing nothing about it, and in confining all human knowledge to the subjective elaborations of our world of appearances. But be they realists or idealists, followers of Fichte or followers of Schopenhauer, whether they mingle much criticism or little criticism with their systems, and whatever other elements foreign to Kantism they may appropriate-we may safely say that three-fourths at least of our contemporary philosophers have felt the influence of Kantian subjectivism in their studies on epistemology.

Then over and above this first influence on our manner of regarding these problems, Kant has exercised yet another still more profound and farreaching influence on the world of modern thought. Before solving the problem of certitude in the way just indicated, he stated the problem, and that in such a fashion, in language so insistent and peremptory, that it has become the problem par excellence of contemporary philosophy. Whether his answer be subjectivist or objectivist, every 
philosopher of the present day must face the troublesome question: "does the analysis of human knowledge give grounds for human certitude ?"

Manifestly the current of thought in the twentieth century is not the same as it was in the thirteenth. Once more, then, what is to be the attitude of the new scholasticism? Can it avoid the new ways where mind and thought are now in acticn, and pursue its solitary course along the beaten-and abandoned -paths of the Middle Ages? No, certainly not; for so it might go on interminably, without ever coming into contact with actual, modern life: a lonely and unnoticed wanderer, seven centuries behind its time.

The recognition of modern trends of thought makes it incumbent on the new scholasticism to take up new positions without abandoning the old ones. It is in the doctrinal domain that we must accomplish the blending of the old and new, of tradition and innovation, that is to be characteristic of the new scholasticism-vetera novis augere et perficere. A cursory glance over the various departments of philosophy will help to illustrate all this.

\section{SECTION 26.-METAPHYSICS. ${ }^{1}$}

128. In the Middle Ages no one doubted the reality of metaphysics. To-day, however, even a slight acquiantance with the various oscillations of philosophical systems will suffice to show how positivists and Neo-Kantians agree in blotting out of the book of philosophy the chapter formerly devoted to what was regarded as a department of the first importance. Either sense experience is

1 For a full treatment of modern scholastic metaphysics, see fourth edition of Mercier's Ontologie (Louvain, 1905). 
the sole criterion of certain knowledge (positivism), or, since the object of our knowledge is disfigured by our own mental structure (Kantism), there can be no possible question of a science that would reach through the phenomenon to grasp the rality bevond, and which would in the forcible language of Aristotle "consider Being as such, and the attributes of Being as such." 1 Some there are, indeed, who would substitute for the older metaphysic a new metaphysic - of the mind. A new review, established about ten years ago, (alled the Rerue de métuphysique et de morale, has repeatedly championed the cause of this new sort of metaphysic. However, a doctrine does not change or abandon its phenomenalistic tendencies by arrogating to itself an ancient title with a well defined meaning.

To this metaphysic of subjectivism the new seholastieism opposes an objective metaphysic constructed on the fundamental ontological doctrines of the Niddle Ages (Section 12). We have no notion therefore of removing from our programme of ontology the questions so eagerly discussed by the doctors of the thirteenth century : the principle of individuation, the distinction between essence and existence, and so many others in which deep analysis can be easily separated from useless subtleties. But on the other hand we are well aware that all is not said and studied once we have exhausted the old medieval repertory. New problems have arisen, attractive problems too, problems which in any case press for an answer from philosophers who live in the twentieth century. And since the very legitimacy itself of the new scholastic metaphysic is called into question, it is precisely this problem that demands our first and best attention. To prejudge the whole question instead of meeting the attacks of the HumeKant-Comte coalition, or to meet them unprepared

1 Metaph. III., I. 
and without counting the cost, would be following an absurd and compromising line of action. Yet such is the conduct of those who proclaim, without establishing, the rights of the Aristotelian metaphysic, or who are content to throw cheap ridicule on the attacks made upon it.

129. What is true of metaphysics in general is also true of most of its fundamental questions. Can we maintain the distinction between substance and accident without meeting the objections of phenomenism? For Huxley and Taine the ego is not a substance, but " a bundle or collection of perceptions bound together by certain relations," "a luminous sheaf consisting merely of the rockets that compose it," just as corporeal substance is, in the well-known words of Stuart Mill, " a mere permanent possibility of sensations."

It would be difficult to overrate the importance of the debate between phenomenalism and substantialism. "There are very few notions with which modern thought is so engrossed as that of substance: friends and foes of the idea are alike convinced that the fate of metaphysics depends on the success or failure of substantialism. At first sight the very existence of any such dispute is matter for amazement. Can it be, we may well ask, that so many thinkers of the first order, like Hume, Mill, Spencer, Kant, Wundt, Paulsen, Comte, Littré, Taine, should have really denied, doubted or misunderstood the substantiality of things and of the ego? Would they not have seen that they were running counter to ordinary good sense? Then, on the other hand, is it credible that Aristotle, with all his genius, was the dupe of such a childish illusion as the phenomenists must needs accuse him of ? Or are we to believe that all those masterly and

1 Huxley, Hume (London, Macmillan, I886), p. 64.

2 Taine, Dr. L'intelligence, vol. I., pp. 77 , et passim. 
truth-loving men, who have incorporated the Peripatetic distinction between substance and accident into the scholastic system and kept it there for centuries, were one and all egregiously deceived in the interpretation of an elementary truth of common sense? Is there not good ground for suspecting that there must have been misleading quibblings and unfortunate misunderstandings on either side, if not on both sides: whence undoubtedly originated mutual bandying of arguments and objections that were quite to no purpose?" 1 Misunderstandings do, in fact, exist on both sides: wrong notions as to the destructive scope of phenomenism, seeing that inasmuch as it allows an autonomous existence to the object of every perception it thereby admits, in a relative sense at all events, the possibility of self-subsisting realities: false conceptions, too, of the scholastic theory as involving the gratuitous and erroneous belief that the human mind is capable of intuiting the specific determinations of natural substances. Here, as elsewhere, a careful comparison of theories is all that is needed to dissipate most of the difficulties and diminish considerably the distance that separates conflicting views. ${ }^{2}$

The same applies to the doctrine of relativity or relativism, so ably defended, from quite a number of different standpoints, by Kant and Hegel in Germany, Comte and Renouvier in France, Locke, Hamilton, Mansel and Spencer in England. The old notion of the absolute, which was one of the keystones of scholasticism, will still be found capable of fixing many an archway in the new edifice, provided it be subjected to the limitations necessarily imposed on all human knowledge.

What a crowd of questions may be opened up between the new scholasticism and contemporary

1 Mercier, Ontologie (Louvain, 1902), p. 263.

"For solution, see ibid., pp. 267 and foll. 
thought! The polyzoistic theories of an Edmund Perrier or a Durand de Gros, regarding the colonies of individual cells in the living organism, must arouse a new and actual interest in the traditional scholastic teaching about individual unity and personality; contemporary pessimism states once more in new terms the old and ever-recurring problem of the existence of evil; the contradictions and inconsistencies of all the modern philosophical offshoots of occasionalism will serve to emphasize once more the profound significance of Aristotle's most fruitful distinction between potentia and actus; while recent controversies on determinism, and on the philosophy of the contingent, are sure to bring out anew the ample resources of Aristotelian teleology. A scrupulous testing of the old metaphysical theories in the light of modern facts and enquiries, so far from proving those theories worthless, will only help to show that they still hold their place in human science as some of the most glorious achievements of the Middle Ages. "Their metaphysics is a fully formed science, as was the logic of Aristotle in their own days. We may abridge or simplify or otherwise modify its details; but we may not change either its fundamental principles or its leading conclusions unless we want something else instead of genuine metaphysics, that is to say, the science of the conditions of Being, formally as such."1

\section{Section 27.-Theodicr. ${ }^{2}$}

130. Modern scholasticism can fearlessly proclaim the precious truths bequeathed to it by the Middle

${ }^{1}$ Domet de Vorges, Essai de métaphysique positive (Paris, I883). p. 330.

2 A neo-scholastic treatise on Theodicy is in course of preparationcoming from the pen of Monseigneur Mercier. [The materials for this treatise are now embodied in the Compendium ( 2 vols.) of the larger Gours de philosophie issued by the Louvain Philosophical Institute. We hope that Cardinal Mercier may find leisure to complete and publish the treatise. - Tr.] 
Ages on the existence and attributes of God. In its conception of the actus purus natural theology ascends as far as mortal may ascend towards the awe-inspiring infinity of the Eternal.

Questions conceming the l)eity have been introduced inte contemporary philosephy from the two main rentres of philosophice:l thomoht outside scholasticism, that is to sir. fiom Kantism and from positivism. All the sytems born of Kant's philosophy have encountered the " thing-in-itsolf," the "unconditioned": some of them to deny it absolutely, the others to declare onr knowledge of it barren and deceptive. Materialists and positivists have found themselves falce to face with the same alternative: some of them, with Comte, have pronounced that supreme Being inacoessible to experience to be simply a chimera: others, with spencer, have banished berond the frontiers of the knowable and ontside the reach of science, that Absolute Being, to whom, or rather to which they nevertheless pay solemn homage.

Hence a sort of introductory question that would have had no meaning in the Middle Iges must now find its place in the opening pages of the modern scholastic theodicy : What are we to say of the agnostic attitude that, Grod being unknowable, it is absurd even to attempt to proce His existence? In other words, we must nowadays justify the possibility of theodicy as well as of metaphysics.

131. Perhaps no one has compiled such an imposing array of difficulties against the scientific value of the traditional proofs for the existence of God, as the author of the " First Principles." The widespread influence of the school for which spencer is spokesman, makes it incumbent on the scholasticism of the twentieth century to examine those new weapons minutely, and to face the assaults of modern positivism. It will not now suffice to simply re-edit the 
reasonings of the thirteenth century, nor even to reproduce the ostentatious defences formulated in the fourteenth when William of Occam began to question the demonstrative force of the Aristotelian arguments (70). Scholastics who would be guilty of adopting such tactics would be like a besieged garrison fortifying the northern side of their citadel while the enemy were actually opening a breach at the south.

Then, too, we must, at the beginning of our theodicy substitute for all special conventional or traditional ideas of the Deity a conception derived by way of observation from the universal beliefs of mankind: that is the God Whose existence must be provedpostponing for the moment the question as to how or how far that world-wide notion of the Supreme Being accords with the philosophical conception of the Divinity. Studies in the history of religions, and ethnological studies generally, can here be of considerable use to the philosopher; they will have valuable materials to offer him.

132. Nor are those the only new points to which special attention must be paid. Many of our contemporaries who acknowledge the existence of a God, have substituted for the transcendent and personal God, an immanent and impersonal one. Never before were there so many different forms of monism. Almost all the German philosophers who acknowledge Kant in any way-as most of them do-are pantheists of some shade or other ; and that even though their several systems are so antagonistic that German post-Kantian philosophy has been not inaptly described as a "civil war of pantheism." Monism has assumed some novel and attractive features in modern philosophy; it claims to offer a solution of problems heretofore insoluble, such, for example, as the mystery of the transmission of causal influence from an efficient cause to a receptive subject 
(Paulsen). Some even go so far as to say that the theory of a transcendent God is unconsciously based on a petitio principii : the last "idol" that awaits demolition.

In the face of these facts and accusations the duty of scholasticism is clear: unless it repulses all such attacks it simply cannot and will not count as a contemporary system of philosophy. Those who are inclined to entertain pleasant illusions on this point might be just now profitably recommended to learn a little in the school of their own masters: monism of various shades was the dominant anti-scholastic system of philosophy from the ninth century down to the Renaissance, and the war waged against it during all those centuries constantly adapted itself to the needs of the time. The refutation of the ancient Greek monists like Parmenides is not the refutation of the materialistic pantheism of David of Dinant, nor of the emanation theory of Avicebron: nor will the arguments directed by St. Thomas against these latter furnish a fully effective answer to such men as Hegel, Fichte, Paulsen, or Deussen.

An analysis of current theories on the nature and existence of God will introduce the modern scholastic to a number of other questions that are being actually discussed in books and periodicals: controversies on the infinite (so often confounded with the indefinite); the nature and foundations of possibility; the question of exemplarism, etc.

Indeed, there is reason to hope that the clash of the new scholasticism with modern ideas will add a number of important chapters to natural theology ; and the sound and sober teaching of former days will be found to contrast to advantage with the wild and fanciful conceptions of the Deity, unfortunately so common in our own time. 


\section{SECTION 28.-COSMOLOGY. ${ }^{1}$}

133. Here we are in a department where the new scholasticism will be busy: firstly, because the medieval errors in terrestrial and astronomical physics would seem to have prejudiced most modern scientists against all medieval teaching on the nature and properties of inorganic matter; secondly, because we must here allow the phenomena to lead us step by step, and these seem to be ever growing in number and complexity according as they are probed and analyzed under the magic influence of the sciences of observation.

In fact, the philosophy of nature at the present day necessarily presupposes a knowledge of physics, chemistry, geology, crystallography and mineralogy. "Where the natural sciences leave off there the domain of cosmology commences." ${ }^{2}$ For, a very considerable number of scientific facts call for some explanation of the origin, nature and destiny of material substance. Such, for example, among those carefully selected by Professor Nys, are the atomic weights of the elements, chemical affinity, atomicity or quantivalence, chemical combinations and analyses with the thermal phenomena accompanying them, the constant recurrence of the chemical elements and compounds; the crystalline structure of matter, isomorphism and polymorphism; all the phenomena of heat, light and sound, together with the electric, magnetic and radio-active properties of bodies; the kinetic theory of gases, the law of gravitation and the law of the conservation of energy.

1 For a full and detailed study of cosmology from the neo-scholastic standpoint, see the work of Professor Nys, Cosmologie (Louvain, 1903, and edit., 1906).

2 Nys, Cosmologie, p. I 3. 
134. Here, truly, are ample materials for a thorough reconstruction of the ancient physics. A reconstruction? But are the essential principles of scholasticism at all capable of assimilating the new facts, or of offering a philosophical explanation of the conquests of modern science? In the face of these facts how will it fare with the theories of matter and form, of substantial change, of specific distinetions between the various bodies and between their various properties, of the rhythmic evolution of forms, and of the finality of the cosmos (Section 14)? These venerable theories sound all the more out-ofdate because neither the great cosmological conception now in vogue-mechanical atomism-nor its less powerful rival-dynamism-have preserved to modern times even a single particle of the ancient seholastic teaching.

And ret what a real surprise there is in store for those who undertake to interpret the new phenomena in the light of the old principles! Professor Nys, after a careful examination of the various departments of physical seience at its present stage of development, has reached a conclusion well calculated to give pause to modern philosophers: the conclusion -which he embodies and supports in his Cosmologie - that no hypothesis of the present day has a better interpretation of the facts of physical nature to offer us than scholasticism has. How, for example, are we to account for chemical affinity, or for the constant. recurrence of the same chemical species in nature, without appealing to a finality that must be intrinsic to the constitution and activities of those species? Is not the great law of crystallography - that "each chemical species has its own characteristic crystalline form" a faithful expression of the scholastic principle that in the inorganic world there are specific types which exhibit distinctive and inalienable properties? In general, does not an impartial study of the facts of 
general physics point unmistakably to the existence of qualities, in the Thomistic sense of the word?

135. Nor is that all. Not only is the new scholastic cosmology constructive in the best sense, it is also destructive of rival systems. . If it is right, atomism is wrong. There is, no doubt, a seductive charm in the very simplicity of the atomic hypothesis, which would reduce the matter of the whole visible universe to one homogeneous mass, and the vast and ever-varying panorama of its manifold activities to simple local motion. But it would appear that the explicative or interpretative value of the theory must be very considerably discounted. Apart altogether from its philosophical presuppositions, which, as can be easily shown, are not entirely free from latent contradictions and inconsistencies, there are in chemistry, physics and mechanics, certain facts such as the constancy of the thermal phenomena that accompany chemical changes, the phenomenon of universal gravitation and the fact of the conservation of energy, with which mechanical atomism -so far from explaining them-turns out on critical analysis to be really incompatible.

And these failures are felt all the more keenly as natural science progresses. So much so, that they have occasioned among certain men of science-who are also betimes philosophers, and, indeed, necessarily so, we would say, judging from their vast and varied knowledge - a movement of reaction against atomism : a fact whose far-reaching significance scholastics will not be slow to realize. Professor Mansion of the University of Ghent has clearly shown ${ }^{1}$ that a series of articles which appeared over the well-known name of Professor Duhem of Bordeaux, may be taken as marking a turning-point in the evolution of cosmological theories, initiating an open and candid return to scholastic conceptions. Professor Duhem has

1 In the Revue des questions scientifiques, July, I90I, p. 50. 
since developed and confirmed his views in a remarkable book ${ }^{1}$ of a synthetic or philosophical tendency, many of whose pages will give food for serious reflection to scientists no less than to philosophers. The chapter in which the author speaks of qualities is specially interesting and instructive. T'ake, for example, these frank and significant declarations: "The attempt to reduce all the properties of bodies to figure and movement must be a futile undertaking, because not only would it involve unmanageable if not unimaginable complications. but-what is far worse - it would be grossly incompatible with the nature of material things. Wive are simply compelled, therefore, to admit into our Physics something else in addition to the purely quantitative elements of which geometry treats: we must allow that matter has qualities. Even at the risk of being reproached for returning to the old cirtutes occultre, we feel ourselves forced to regard as a primary and irreducible quality that by which a body is hot, or bright, or electric, or magnetic: in a word, we must abandon the conceptions and hypotheses that scientists have been incessantly making and unmaking. in the spirit, and since the time, of Descartes, and begin to attach our theories to the fundamental conceptions of the peripatetic Physies." After which the author goes on to ask: "Will not this retrograde step compromise the whole vast body of doctrine organized by physical scientists since they shook off the yoke of the school? Must not the most fruitful methods of modern science at once fall into disuse? Convinced that everything in corporeal nature was reducible to figure and movement as conceived by the geometricians, that all was purely quantitative, physical scientists have long since introduced measure and number into every department of physical research ; all the properties of bodies are become magnitudes;

${ }^{1}$ L'évolution de la mécaniquc rationelle, Paris, I903. 
-all laws, algebraical formulas; all theories, chains of theorems. And are we now to be asked to sacrifice the marvellously powerful assistance we have derived from the employment of numerical symbols in our reasoning processes?" To which questions he gives the answer that: "Such a sacrifice is by no means necessary. To give up mechanical explanations does not mean to give up mathematical Physics. Numbers can be used to represent the various degrees of a magnitude capable of increase or diminution; and the transition from the magnitude to the number that is made to stand for it we call measuring. But numbers can also be made to stand for the various degrees of intensity of a quality. Such extension of the concept of measure, by which number is made to symbolize a thing that is not quantitative, would no doubt have shocked and astonished the peripatetics of former times. But that just reveals the real, genuine progress, the abiding and really fruitful conquest for which we are indebted to the seventeenth century scientists and their followers; in their attempt to substitute everywhere quantity for quality they failed; but their efforts were not altogether without results, for they brought to light this truth of inestimable value: That it is possible to deal with physical qualities in the language of algebra." From all of which emerges this interesting conclusion: "Physics will reduce the theory of the phenomena of inanimate Nature to the consideration of a certain number of qualities; but this number it will aim at making as small as possible. Whenever a new phenomenon appears Physical Science will do its utmost to, find a place for it among the known qualities; and only when it has finally failed to do so will it resign itself to the admission of a new quality, into its theories, of a new variable into its equations."

The testing of what we have ventured to describe as the harmony of science with the old scholasticism, 
would seem to be specially interesting here in cosmology in its application to this particular theory of quality; it is very likely to throw additional light on the general observations made above regarding the possibility of such harmony: this is our excuse for making such long quotations from the work of Professor Duhem. ${ }^{1}$

\section{SeCtion 29.-GeNeral PSYCHOLOGY. ${ }^{2}$}

136. The numerous sciences which might be grouped as anthropological-cellular biology, physiology, histology, embryology, etc.- - have pushed back almost indefinitely the horizons of this continent which the Cartesian psychologists of the seventeenth century were congratulating themselves on having explored so thoroughly. Now, as regards the "anthropological " or "human " problems raised by the progress of these sciences, the exaggerated spiritualism of a Descartes or a Cousin-traces of which are still to be found in certain educational centres-must logically disclaim all right to meddle with such problems at all. And positivism, on the other hand, has been in the habit of claiming a sort of monopoly in these studies; approaching them, too, with its well-known agnostic prejudices, and confining itself to the mere accumulation of facts and experiments instead of making these latter subservient to the ulterior study of the human substance. The new scholasticism, however, thanks to its fruitful theory of the substantial union of soul and body, "is in possession both of a systematic

3. As for dynamism, so ably defended by Boscovich, Carbonelle, Hirn, Palmieri, its star has speedily paled. The denial of formal extension, and the denial of a passive element in corporeal things, are positions inore and more difficult to defend as natural science progresses.

'We may refer the reader to Mercier's monumental work, La Psychologie, already (1903) in its sixth edition. 
body of doctrines and also of an organic framework quite capable of receiving and assimilating the ever increasing products of the sciences of observation." In truth, when we reflect on the march of scientific progress, and on the crowds of new and pretentious theories that are being continually put forward in explanation of newly discovered facts, we cannot suppress our astonishment at the reserved and cautious attitude of the old Aristotelian and scholastic psychology. To realize it fully we should have to explain in detail the position of the new scholasticism in regard to the problems raised by contemporary psychology. For this, however, we must be content to refer the reader to treatises on neo-scholastic psychology; here we can hardly do more than enumerate in a passing way the questions that are of greatest prominence and importance. These have reference, some to the activities, others to the nature of man.

137. The elementary vital phenomena brought to light by cellular biology have become the startingpoint of psychology. It is, however, from observing the manifestations of sense life that psychological science has derived most profit-thanks to the many remarkable discoveries made by physiology regarding the structure and functions of the nervous system. The new scholastic psychology has found in the medieval teaching a most appropriate framework of broad, leading principles-made to order, one would almost say-for the interpretation of the latest facts in connection with unconscious mental states, with cerebral localization, with the proper and common sensibles, and especially with the objectivity of our muscular and tactual sensations. The various phenomena of the association of psychical states,

'[Op. cit., Preface, p. 1.-Richet (Revue scientifique, t. LI., 1893), and Döring (Zeitschrift f. Psych, u. Physiol. d. Sinnesorgane, 1898, pp. 222-224), agree in recognizing this vitality in the new scholastic psychology. 
so ably analysed by English psychologists, with its manifold applications to language, to the training of animals, to hypnotism, etc.; and all the recent minute analyses of instinct, sense memory, the passions, spontaneous vital motions, etc.; entirely confirm traditional scholastic teaching on the cognitive and appetitive states of sense life. Notably the important scholastic thesis that sense knowledge of whatsoever kind reveals the particular and contingent -is sustained and corroborated by all recent researches.

But as against positivism, it is now more necessary than it has ever been in the past to establish fully and clearly the essential distinction between the sensation and the idea. The objections of a Berkeley that the process of abstraction is chimerical, and of a Taine confounding the class-name with the idea and the composite image with what he describes as the so-called universal concept-must be fairly faced, examined and answered at any cost. Therein will the new scholastic ideology show itself more fertile and powerful than either the systems based on sensism where all knowledge is reduced to sensation, or the ultra-spiritualist psychologies (of Descartes, the ontologists, etc.). where the part played by sensation in the genesis of our ideas is either unduly diminished or entirely ignored.

The study of the will involves a discussion of all the arguments urged by determinists against human liberty; and that of itself implies some degree of acquaintance with practically all contemporary systems of thought. Reason and liberty, so radically distinct from sensibility and instinct, set up an insuperable barrier between man and beast: an assertion which, however, by no means denies that the higher and lower faculties exert a mutual influence on one another ; for the solidarity of sense and reason is abundantly manifest in waking, sleeping and 
dreaming, in the normal life of the mind as well as in hallucinations and insanity; and, furthermore, the close union of sense appetite with rational will can alone explain the phenomena of the passions, and the abnormal and morbid states of the will itself.

Modern philosophers should be interested if not surprised to see what a simple and adequate explanation of all these phenomena of interdependence between sense life and rational life the new scholasticism has to offer us in its theory on the constitution of the composite nature of man. We pass, therefore, to the problems regarding man's nature.

138. Neither the recent controversies on the nature of life, like that, for example, between the mechanical organicists and the vitalists of the school of Montpellier, nor the evolutionary hypotheses of a Weissmann or a Darwin, have in any degree discredited the time-

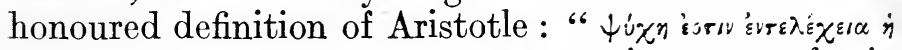

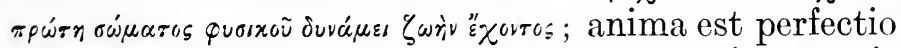
prima primusque actus corporis naturalis organis præditi." " The functional unity of the composite animal being, the manifest solidarity of its various forms of energy, confirm the theory of the substantial union of the animal body with the vital principle; nor is the divisibility of the living organism an insuperable objection against this theory. The psychology of the Middle Ages will be found to be at least quite as capable as any other system, of explaining the vital phenomena of the vegetable and animal kingdoms. At the same time it will give a decidedly better explanation of the various facts of human life. If man is in substance both corporeal and spiritual he ought naturally to be the seat both of organic and of immaterial or spiritual activities; and even the highest manifestations of his psychic life should reveal a functional dependence on the

${ }^{1}$ De Anima, ii., 1. 
nervous system. Neither the extreme Cartesian spiritualism which makes the body a mere encumbrance to the soul, nor the occasionalism of a Malebranche or the pre-established harmony of a Leibnitz, nor the attempts of positivists to reduce the psychic fact to an obverse or inverse of the nervous phenomenon, nor even the more recent theory of psycho-physical parallelism, can offer us any adequate or satisfactory explanation of the unity of man and the solidarity of his acts. ${ }^{\prime}$ But the new scholastic teaching will throw an important light on more than one of the leading chapters of contemporary psychology: for instance, the whole doctrine of character, and of personality with its "variations," is subordinate to the main principles concerning the substantial unity of man.

Again, the new scholasticism will have to examine the urgent objections of materialism against the spirituality and simplicity of the human soul: objections drawn from the dependence of even our highest rational activities on the corporeal organism. Besides which there are the questions as to the soul's origin and immortal destiny, etc. So that on the whole the new scholasticism will have to subject the psychological teaching of the medieval doctors to a careful and thorough process of modern adaptation and enlargement.

139. Nor is this all. So rapid has been the progress of psychological studies in modern times that the branches of the parent stem have begun to show a vitality of their own. Of these new sciences some are purely psychological, as, for instance, criteriology. Others draw more or less from independent philosophical sources, like esthetics; or from the natural, physical, or social sciences, as is the case with psycho-physics, didactics, pedagogics,

"Cf."Mercier, Les crigines de la psychologie contemporaine (Louvain. 1897). 
folk-psychology and the numerous other forms of applied psychology.

\section{SECTION 30.-CRITERIOLOGY. ${ }^{1}$}

140. Scholasticism has treated the criteriological problem mainly from the deductive point of view, deriving a synthetic theory on certitude from divine exemplarism combined with a metaphysical teleology $(72,68)$. But the present-day scholastic must meet the question of the validity of knowledge in the domain of the analysis of that knowledge itself, and must aim at finding an inductive solution for it: the critical turn taken by modern philosophy from Descartes to Kant, and even more decidedly since Kant's time, will leave no aspect of contemporary intellectual problems unexamined (127).

Now, the certitude of human knowledge, " being a modality that affects the cognitive faculty, should find its ultimate explanation in the nature of the human soul. Criteriology, therefore, springs naturally from the study of the soul, that is to say, from psychology. It is only confusion of thought and misuse of language that could have assigned to it a place in the logical treatise and designated it by the curious though now familiar title of "real logic."

It is easy to see that nothing less than the whole scholastic system is at stake in the controversy about the objectivity of our intellectual judgments. The traditional scholastic theories on truth (logical and ontological), and notably the division of propositions into those in necessary matter (per se notce) and those in contingent matter (per aliud notce), theories so well known to the doctors of the thirteenth centurycan serve as the foundation of quite a new and

\footnotetext{
1 See Mercier, Critériologie générale, (fifth edition, 1906). A volume on Critériologie spéciale is promised.

Mercier, op. cit., p. 4 (fourth edition).
} 
complete scholastic criteriology. Our venerable master and colleague, Monseigneur Mercier, who is rightly recognized as the founder of this special department, has admirably shown the latent resources of these old doctrines, and has made successful use of them in vindicating a rational type of dogmatism both against the methodic doubt of Descartes and against the exaggerated dogmatism of Balmes and Tongiorgi.

141. Certain truths (or judgments) have for their object relations between objective concepts, abstract. ing altogether from the existence of the things conceived: the objective manifestation of these relations to the mind is of the ideal order, as in the so-called exact or rational sciences. But these truths are in turn intended to be applied to a real, extramental world; by which application the laws of these ideal relations become the laws of things. Hence a twofold epistemological problem: that of the objectivity of propositions of the ideal order, and that of the objective reality of our concepts.

The supreme and ultimate motive for our certitude about immediate propositions of the ideal order (and consequently about propositions deduced from these) cannot possibly be found in any extrinsic test of the kind to which De Bonald, De Lamennais, Pascal or Cousin have had recourse; neither can it be found in an exclusively subjective criterium like that offered by Kant in his second Critique, and by the neo-critical theories sprung from that part of the German philosopher's innovations; those principles of the ideal order must have their final and fundamental motive in an objective, intrinsic criterium, i.e. in the evidence of their truth. ${ }^{1} \quad$ And that is precisely why the new scholastic criteriology must study in every detail, and encounter point by point those masterful contents of the Critique of Pure Reason, in which

.' Op. cit., p. 201 (fourth edition). 
Kant is led to fix upon a blind synthesis, necessitated by the structure of our mental faculties, as the sole explaining reason of the necessity and universality of those propositions which we hold for absolutely certain. Even the first principles of the mathematical sciences, such as $7+5=12$, Kant would hold to be the product of an a priori synthesis.

Then, on the other hand, the universality of propositions of the ideal order must also be defended against the attacks of contemporary positivism, which flatters itself that it has demolished the doctrine of the existence of abstract concepts and shown them all to be reducible to mere sense experiences.

142. The second great problem of epistemology is even of more consequence than the first; for what would it avail to have universal and necessary judgments, motived by objective relations revealed to our minds between subject and predicate, if this whole object were merely and purely representable, and corresponded to nothing in the real, extramental order of actual or possible existences ? The Kantian phenomenism which proclaims our inability to attain, by means of our concepts, to the thing-in-itself, is a logical corollary from the synthetic-a-priori theory of judgment. Kant pronounced himself all at once against the real as well as against the ideal objectivity of judgment.

In this all-important discussion a very vital doctrine of the new scholasticism is at stake: the legitimacy of the process of abstraction. What we have to show clearly is this, that in forming our concepts from the data of sense we remain throughout in permanent contact with the realities of nature. For if we do, then "the intelligible forms which become the first subjects of our judgments are endowed with a real objectivity; in other words, the intelligible object of these forms is not only a 
representable object but, more than that, it is also a thing-in-itself, actual or possible."

It is obviously upon the real objectivity of our sensations that the force of this reasoning depends; and to that point we shall refer again presently. Here we may be allowed to draw attention in passing to the remarkable renewal of interest which the problems of modern philosophy have aroused in the venerable old question of the universals-now having a noble revenge for all the ignorant abuse and ridicule so often heaped upon it. The first great, actual question of criteriology is in very truth none other than that of determining whether the moderate realism of Aristotle and St. Thomas is a sound philosophical attitude as against the nominalism of Hume, Mill, Taine, etc., on the one hand, and the exaggerated realism of the ontologists and of a group of German pantheists on the other. How plain it appears from all this that modern and contemporary philosophy has gradually developed into the one vast and deep criteriological problem of the meaning and value of human knowledge.

143. After the study of certitude in general comes the study of the certitude of at least the more important among our separate and individual convictions. These form the subject-matter of special criteriology. First in importance comes the investigation into the objectivity of our external sensations. Setting out from the incontestible presence in consciousness of a sense datum or material -in the shape of a representative impression-of which we are manifestly not ourselves the creators, the earlier Kantists, and after them Schopenhauer and Herbart, inferred the existence of a noumenal world as the cause of those impressions. It is by an analogous application of the principle of causality that modern scholastieism argues from our consciousness of passivity in sense perception to the reality of an extramental object 
which engenders in our faculties that peculiar reproduction of itself called a sensation. Consciousness itself, enlightened by mature reflection and reasoning, can alone meet the many objections of contemporary positivism against the existence of an external world.

Each and every distinct source and form of knowledge must find its justification in special criteriology : there the scientific syllogism as understood by Aristotle and the great teachers of the Middle Ages will be vindicated against the attacks of such men as Mill and Bain who make out all deduction to be either a solemn farce or a petitio principii ; induction will be placed on solid, scientific foundations, and carefully distinguished from the positivist summing up of particular facts into a collective proposition; neither memory, nor belief in authority whether human or divine, nor even consciousness itself, can give us certitude, except with the aid of certain safeguards and guarantees that need to be carefully and accurately determined and analyzed in this department.

\section{Section 31.-Esthetics. ${ }^{1}$}

144. The Middle Ages produced no special treatises on the study of the beautiful. The ideas entertained by the medieval scholastics on the subject are found scattered through their metaphysics and psychologies, or in commentaries like those on the treatise of Pseudo-Denis De Nominibus Divinis.

Esthetics did not make its first appearance as a distinct branch of philosophy until after the time of Leibnitz. Etymologically, it should be the title of the philosophical science of sensation (ärobavouar, sentire), and the term was used in this meaning by

1 A philosophical science of esthetics conceived after the spirit of the new scholasticism, remains yet to be constituted. In the present Section we merely outline the general plan of the questions which we conceive to fall properly within its scope. 
Kant in describing as the Transcendental Esthetic his doctrine on the application of the space and time forms to the materials of sensibility. Baumgarten was the first to employ the term "esthetic" to designate the science of the beautiful. Nor was he thereby doing violence to the etymology of the word, for in his time the science of the beautiful meant almost exclusively the science of our sensory and emotional states.

145. But that narrow and inadequate conception of estheties has nothing to recommend it. For modern scholasticism as for the Niddle Ages the idea of the beautiful is complex; it is "an impression caused in us by an object capable of producing it." Esthetics ought, therefore, to comprise two, or eren three, distinct groups of questions: about the subjective elements of the beautiful, about its objective elements, and about the correspondence of the former with the latter. Understood in this way, esthetics would represent a mixed science in the general classification of philosophical studies: it would borrow from psychology the requisite materials for explaining the impression or perception of the beautiful; and from metaphysics whatever belongs to the constitution of those things to which we attribute the prerogative of beauty. Parallel with this treatment of general questions it would also embrace certain special branches devoted to the study of the great leading manifestations of the beautiful both in nature and in art. Let us take a glance at those various departments.

146. The subjective impression is an element essential to the beautiful. This impression is a double phenomenon; it can be analysed into a cognitive perception and a specific gratification or enjoyment. Of course, every conscious activity that is exercised within certain limits of intensity and duration can be a source of pleasure; but not every source of pleasure is esthetic, as the positivists 
seem to think and to teach. Esthetic pleasure is the epiphenomenon of a perceptive or cognitive activity (quœ visa placent); and if we examine the objective factors (147) of this pleasure we shall find that the perception in question must be of the intellectual order. The enjoyment of esthetic pleasure resides formally in a disinterested contemplation, a "superfluous" activity (Spencer), a "play" impulse without any direct and immediate utility (Schiller). Moreover, in the perception of sensible beauty, the abstraction which conditions intellectual apprehension springs from the agreeable feeling in the sensations, and thus the sense pleasure is always closely associated with the intellectual.

The contemplation of the beautiful is the cause of a very special and indefinable sort of tranquility, calm, peace. The esthetic enjoyment of sensible beauty is likewise a harmonious pleasure; it diffuses itself over man's whole conscious life: but it could not be harmonious did it not respect the fundamental hierarchy established among man's various mental faculties.

147. The object of this subjective perception is the perfect order of the thing perceived (unde pulchrum in debita proportione consistit). But perfect order in a thing implies a multiplicity of parts (integritas, magnitudo), the relative importance of each depending on its functional value compared with the whole (debita proportio, aqualitas numerosa, commensuratio partium). It is to the formal constituent (the forma) of any being or thing that we must refer the factors of its intrinsic orderliness, for the forma is the principle of its unity, the thing being then perfect when the arrangement of its parts realizes fully and adequately the constitution demanded by its nature (64).

148. The esthetics of the ancient Greek philosophers investigated almost exclusively the objective elements 
of beauty, either confining their attention to objects which revealed proportion and harmony in their constitution (Platonic and Aristotelian school), or considering beauty as a transcendental attribute of Being as such, and therefore as abiding in simple as well as in composite things (Neo-Platonic school).

Modern estheties, on the other hand, carried to the opposite extreme by most of its representatives, would have beauty to be a purely subjective phenomenon, either the outcome of an a priori form (Kantian and post-Kantian schools), or of some semi-conscious of subeonscious activity (Leibnitzian school), or of any and every agreeable or useful sensation whatsoever (positivism, utilitarian esthetics).

The superiority of the new scholastic esthetics arises from the close correlation it establishes between the orderliness of the thing and the impression it is calculated to produce in us. It completes the Greek by the modern point of view, and reciprocally. It also insists that the objective constituents of order must be excitants of a lind conformable to the contemplative activity of the being that apprehends it.

It is only by analyzing this causal relation that we can mark off the complex notion of beauty from the purely metaphysical notion of perfection: a vast multiplicity of elements may conceivably be necessary for the objective perfection of a thing, but it would mar the work of art by fatiguing the faculties of perception; for the objective integrity of a perfect thing, the real, physical presence of all its elements without exception is essential; for its esthetic integrity, on the contrary, all that is needed is that the spectator have the " impression " of integrity, and the deliberate omission or bare outlining of certain parts is a trick well known to artists, by which they arouse the contemplative activity of the auditor 
or spectator and thus make him a sort of sharer in the creative work itself. The claritas pulchri, so often spoken of by the scholastics, is an admirable expression of this comprehensive teaching, for it has in view that " property of things in virtue of which the objective elements of their beauty, that is to say, their order, harmony, proportion, reveal themselves clearly to the intelligence, and so elicit its prolonged and easy contemplation."

149. The efficient agencies productive of the work of art are the creative faculties of man-chiefly imagination and intelligence-subserved by the rules or technique of each particular department. This technique is brought to bear on certain sense materials (the material cause of the work of art) and so fashions them as to realize some ideal (the formal cause of the work of art). This artist's ideal is no mere misty dream, but a concrete image in which he has embodied all the objective elements he aims at realizing in his work, and has so embodied them that the functional role of each will contribute to the total impression he wishes to produce. This impression will depend on the resplendentia forma, that is, on the "form" made to shine forth from the artist's work (63). Whether it be the "substantial form" of the being, or some "accidental form " that the artist has chosen to body forth (what Taine calls the caractère dominateur), the more prominently he makes this unifying principle stand out and "shine forth" -resplendere-the fuller, richer and easier will be our knowledge of his masterpiece, and the more powerful the impression it will make upon us. Thus we see the verification of what a scholastic, nourished by the wholesome doctrines of the thirteenth century, has written on this subject: " Pulchrum in ratione sua plura concludit: scilicet

1. M. De Wulf, Études historiques sur l'esthétique de saint Thomas d'Aquin (Louvain, I896), p. 28. 
splendorem formse substantialis vel accidentalis supra partes materiæ proportionatas et terminatas."

If this philosophy of art is to be fruitful it must spring in the first instance from the close study of the best masterpieces. Art criticism and art history contain the materials from which the philosopher of estheties must abstract his theories: they are to esthetics what the sciences of inorganic nature are to cosmology, and the biological sciences to psychology. We may here copy the example of positivism, which approaches the study of art problems by the study of masterpieces. The method is entirely in harmony with the peripatetic ideology. It will also prove a valuable test for the new scholastic esthetic. for if the principles of the latter are true they will be able to interpret and to justify the rules and canons followed by the great masters.

Then, there remains the final cause of art. Its essential aim is of course the production of the beautiful, but we may inquire whether it has not also some extrinsic mission: Has it a social or educative significance? Should it come out among the people or remain the exclusive privilege of a coterie of initiated worshippers? How can we deny it all influence on the moral life of the individual and the community, provided we keep clearly before us the distinction between the finis operis and the finis operantis? These, however, are questions of ethics and sociology rather than of esthetics.

150. To conclude: Esthetics has its place clearly marked out in any comprehensive study of the new scholasticism : it is a natural offshoot from psychology and metaphysics. A thorough and modern scholastic treatment of it should yield an adequate and satisfactory explanation of the many modern problems that have grown up around the concept of the beautiful; therein shall we find yet another

I- Opusc. De Pulchro ct Bono, ed. Lccelli, p. 29. 
illustration of the striking cohesion and marvellous elasticity of the great organic doctrines of Middle Age scholasticism.

SECTION 32.-OTHER BRANCHES OF A PSYCHOLOGICAL CHARACTER.

151. Psycho-physics, or psycho-physiology, or physiological physiology, or experimental psycho$\operatorname{logy}^{1}$ as it is variously called, is a very modern science, based on external as well as internal observation, and having for its object the discovery of the relations between the phenomena of consciousness and their physiological concomitants. Attaining to a remarkably sudden popularity among men of science, who are naturally partial to those halfpsychological, half-physiological forms of research, the new science has already made the rounds of Europe and America. At the present time it has chairs and laboratories in most universities.

Now, no excessively spiritualist system of philosophy which regards the immaterial soul of man as entirely independent of his body, can consistently give any countenance to this whole department of research ; while, on the other hand it fits in admirably with the spirit of the new scholasticism, and especially with its cardinal psychological doctrine of the substantial union of spirit with matter in the unity of composite human nature $(137,138) .^{2}$

The conclusions formulated by Weber and Fechner on the quantitative relation of the sense-stimulus to the intensity of sensation, and their further verification by Wundt; the results brought to light by

1 A scholastic psycho-physiology is as yet scarcely outlined.

i [Cf. art. by Dr. Gasquet in the Dublin Review, April, I882, on " St. Thomas' Physiological Psychology."-Tr.] 
experiments made with such instruments as the dynamometer and the plethismograph; the observations made with regard to the duration of psychic phenomena and the limits of conscious sensibility: these, and a whole series of cognate investigations undertaken within the past ten or fifteen years and chronicled in numerous reviews, treatises and monographs, are all quite in accord with the spirit of modern scholasticism, and even amount to a striking vindication of its psychology.

What, then. could be more natural on our part than to extend a sincere weleome to these "new ways" and to contribute our quota to researches that are sure to enrich our philosophy and reflect credit upon it?

Scientific men of the most widely divergent schools of thought have frequently noticed the remarkable plasticity of medieval psychology. We need only instance the testimony of one of the well-known founders of the science of psycho-physics, Professor Wundt of Leipzig. who states, towards the end of his Principles of Physiological Psychology, that the results of his researches do not fit in with materialism, nor with Patonic or Cartesian dualism: and that the only theory which attaches psychology to biology and thereby presents itself as a plausible metaphysical conclusion to experimental psychology, is the theory of Aristotelian animism. ${ }^{1}$

152. Very closely connected with psychology we find a large number of problems relating to the education and instruction of the young. To draw out the intelligence and form the character, we must be thoroughly conversant with whatever in any way influences the normal functioning of the mental activities. Psychology is, in fact, the very groundwork of didactics and pedagogy. And as there is

1 Grundrige der physiologischen psychologie, v. ii., P. 540. 
a new scholastic psychology, so will there be new scholastic didactics and a new scholastic pedagogy. ${ }^{1}$

It is customary nowadays to distinguish between didactics, or the science of instruction, and pedagogy, or the science of education. And such a line of demarcation exactly coincides with the Thomistic theory of the real distinction between at least the higher faculties of the soul-the intellect and the will (62). But, beyond and apart from this, the solidity and reasonableness of the new scholastic psychology stand revealed in all the various departments of didactics and pedagogy ; for it offers an adequate explanation of quite a number of rules and maxims universally held by teachers and educators of experience. Here, then, again, the new scholasticism can rightly set up its principles in opposition to those of the Herbartian and positivist schools of pedagogy. An example or two will prove instructive.

It is the province of didactics not merely to prescribe the sciences and arts to be taught, and the order of teaching them, but also to lay down the right methods for teaching them-the methods common to all and the methods peculiar to each. ${ }^{2}$ Now those methods as a whole are an illuminating commentary on scholastic ideology. Why does the master proceed "from the concrete to the abstract" ? Why does he stimulate and sustain attention by employing "intuitive" methods? Why does he freshen and enliven his teaching by descriptions, illustrations, examples, etc.-if it be not because that great principle which governs our whole psychic life applies in a special manner to the earlier developments of our cognitive faculties : Nihil est in intellectu quod prius non fuerit in sensu (89) ? The abstractive

${ }^{1}$ Willmann has published a Didaktik (third edition, 2 vols., 1903), in keeping with scholastic principles, as well as numerous other writings on pedagogy.

2 We have touched on some of the questions of philosophical pedagogy in Section 21. There are several others, as, for example, that of the order in which the various branches of philosophy should be taught. 
process which engenders the universal concept and leads to the formulation of laws, must be constantly nourished by the products of perception and imagination, whatever be the subject-matter of our study. On the other hand, the master is not to spoon-feed his pupils with fully-cooked items of information. but rather to draw out and encourage the exercise of those faculties by which the pupil, through his own personal effort, will acquire knowledge. The pupil must be active in assimilating knowledge: its communication must excrt a formative influence on his faculties. So the scholastic principle finds its application: "Quando igitur preexistit aliquid in potentia activa completa, tune agens extrinsecum non agit nisi adjuvando agens intrinsecum, et ministrando ei ea quibus possit in actum exire."

Mere instruction is not an end in itself; it should contribute to the formation of personality, and should therefore have its place assigned to it among the many factors of education proper. Those engaged in the education of youth are well aware of the importance of an equal and well-balanced development of the merely sentient impulses and of the free, rational activities. The full exercise of physical vitality has its influence on the moral side of life ; judicious bodily exercise is an aid to mental activity; the passions may be made the enemies or the allies of sound moral training. And why all this ? Because, as modern scholasticism teaches, there are not two beings in each of us, a body and a soul, but one substantially composite being; while, on the other hand, rational volition, whether free or necessary, is intimately dependent on the organic appetites (137, 138).

It has been said that education is simply the cultivation of good habits. Nothing truer, if we understand habit in the strict scholastic sense of

${ }^{1}$ St. Thomas, De Fertate, Q. XI., art. I, in corp. 
habitus or dispositio. Since the repetition of any act begets in the faculty a permanent disposition or facility to perform that act (85), the principal duty of the educator will be to guide and watch over the faculties of the pupil in the process of acquiring those good habits. And as the human soul is not a mere loose bundle of independent forces, since the harmony of the various mental activities demands a subordination of the faculties, psychology will place in the teacher's hands this important practical principle: that in the child or youth the ruling faculty must be the rational will. Mistress of itself and of all its energies, the soul ought to guide all these towards the proper end of all. The exercise of the will-faculty, as of any other faculty, demands effort; and effort begets moral virtue: for the man of character is the man who can direct and control himself in conformity with the exigencies of his end or destiny, that is, of his perfection. ${ }^{1}$ Thus man's moral destiny fixes the educational ideal.

Finally, we may note that as the didactics and pedagogy which deal with the formation of the single, separate individual, derive their support from general psychology, so will they need to draw from other sciences when they regard the individual not as isolated, but in his actual social and historical setting. Here the sciences of education will have to address themselves to a group of phenomena concerning the growth and development of the energies of the whole vast, complex social organism. Just in this domain have didactics and pedagogy received a considerable impetus and extension in quite recent

1 Besides intellect and will, many moderns recognise a third faculty, sentiment, which, they say, should receive special training. As scholastics consider sentiment, feeling, affection, emotion, etc., to belong mainly to the appetitive faculty [and in some degree to the cognitive], they do not admit this tripartite division into their didactics and pedagogy [though, of course, they fully appreciate and analyze the conscious states referred to]. 
times. ${ }^{1}$ Education is influenced by political forces, by the standard of domestic and social morality, by religion. by the various factors which history chronicles and criticizes. The character of the instruction given to routh will always depend on the prevailing conditions and conceptions of literature, science and art. Educationalists may therefore expect to find valuable lights and helps from studying the history of civilizations. They will also be aided by ethical statistics. which point to the reciprocal influences of human liberty and of racial and criminal phenomena: by "folk-psychology." with its findings on the formation of language, on religion, and on morals.

153. The contact of general psychology with philology, ethnology and history has given rise to a new group of psychological researches which Lazarus and Steindhal have called by the name of Volkerpsychologie, and which have been more clearly mapped out and described by Wundt in his great work bearing that title." This folk-psychology, or collective psychology as it might be called with greater accuracy and propriety, studies the psychological phenomena of the human crowd, of collective humanity as such, abstracting from all particular circumstances of time and space. Such, for instance, are the phenomena of language. of public worship or religious rites and of public morals, to which Wundt has chiefly devoted his attention. There are many other analogous groups of phenomena: the psychological manifestations of grouping by families, by professions, by states; of union on grounds of utility or pleasure ; of the mere human crowd as such: all these fall within the scope of the new science.

${ }^{1}$ See Willmann, op. cit., vol. I., p. 29, with its interesting introrluction, pp. I-98. The full title of the work is : "Didaktik als Bildungslehre nach ihren Beziehungen zur Socialforschung und zur Geschichte der Bildung."

2 Leipzig, I 900. 
This folk-psychology has a special bearing on sociology, which studies from a general standpoint the mutual dependence of all social phenomena on one another. The former science does not embrace all the psychic facts which might be assigned to sociological psychology. It leaves the latter science to investigate the influence of the social milieu on the mentality of a given individual, as also the influence a powerful personality might wield over a given social state. ${ }^{1}$ These two latter questions belong at the same time to what has been called "individual psychology." About the idea that inspires this latter branch, and a few of its applications, a word may be said in conclusion.

154. General psychology deals with the abstract type; it studies man, not men. But individual differences are so many revelations of each distinct personality, so many factors of the individuation of one common specific nature (66). There are, first of all, characteristics peculiar to certain classes of men. Accurate observation discovers the influences of such factors as age; and notably the science of child-psychology (pédologie) -itself still in its infancy - traces the development of child-life in the greatest diversity of surroundings: among civilized and uncivilized peoples, in normal and in abnormal circumstances. Other explorers are accumulating the first materials ever collected in view of a sexpsychology; others again are studying the innumerable modifications and disturbances wrought by disease and illness on ordinary psychic phenomena; while investigators in the domain of criminal anthropology are busy comparing the moral type of man with the criminal.

Further still, by analyzing the data of philology,

1 See some observations by Pere De Munnynck, in the Mouvement sociologique, published by the "Societé belge de sociologie," I9OI, pp. 157 and foll. 
ethnography and history, we might build up an ethnical psychology, a psychology of each of the different nations or races of people. And finally, individual biography may be developed in certain cases into a psychology of such types-or exceptionsas Julius Caesar or Napoleon; a psychology which will analyze those infinitely small perceptions of which Leibnitz speaks, and which stamp on each conscious being the indelible seal of individuality. ${ }^{1}$

155. Whatever be the future achievements of folk-psychology and individual-psychology, the new scholasticism would seem a priori to possess certain fundamental doctrines capable of shedding not a little light on these obscure places. Its theories on the origin of language and on the moral aspirations of man, explain at least as clearly as evolutionism the phenomena of language and religion. The scholastic ideology offers a satisfactory explanation of the genesis of conscious states in the child; the mutual dependence of psychical and physiological functions in a being composed of matter and spirit and endowed with substantial unity, will explain the various phenomena of sexual psychology, the strange facts brought to light by pathological psychology, and so on.

\section{Section 33.-EThics AND NATURAL Right.}

156. The century just elapsed has witnessed the rise of the most widely divergent systems of moral philosophy. Utilitarian ethics are the offspring of the materialism and positivism which would identify happiness either with an exclusively egoistic wellbeing whose factors may be weighed and measured

\footnotetext{
- Under the title of comparative psychology or animal psychology we may group all investigations into the similarity and dissimilarity of men and animals in regard to their respective states of consciousness.
} 
by a sort of "moral arithmetic," or else with the altruistic well-being of humanity in the lump. Spencer has attempted the reconciliation of egoism and altruism in his imposing synthesis of the evolutionist philosophy: moral conduct has had its first faint, far-away beginnings in the pleasure attending the most elementary processes of conscious life: its evolution runs in a groove parallel to organic evolution: it will finally usher in a social state in which a perfect harmony will be realized between altruistic feelings and egoistic or individual wellbeing. The evolution-craze is accountable for some sufficiently wild and fantastic speculations in the domain of ethics as elsewhere. Most evolutionists, however, have (with Leslie Stephen) abandoned the Spencerian idea of an ultimate state of moral equilibrium, and rather seek the morality of human conduct in its continuous adaptation to the actual exigencies of a social state that is subject to perpetual evolution. If this be so, there is manifestly no intrinsic difference between good and evil; and the evidences of history, anthropology and ethnography are pointed to as showing that the test of morality has ever and always varied with the time and circumstances. . . . . In other directions the rigid stoicism of Kantian ethics would have us act independently of all self-interest, of all motives extrinsic to duty, and obey the law for its own sake (the categorical imperative). Schopenhauer's pessimistic ethics, originating in the Kantian concept of the noumenon, regards all nature, man included, as a series of objectivations of will, appearing only for the endurance of struggle and misery. Pessimism has more recently rid itself of its Kantian associations, and still survives, though more as an attitude of feeling or sentiment than as a philosophical system. These are but a few out of many modern ethical systems, all so utterly defective and unsatisfactory 
that well-known moralists like Sidgwick have passed through all of them and found rest in none. ${ }^{1}$

Nor has any single theory of scholastic ethics found a place in this chaos of modern systems. Can the time-honoured teachings of scholastics on the last end of man, his freedom and responsibility, on good and evil, law and duty, reward and punishment-be still maintained in the twentieth century? If they can, it will be by bearing the brunt of modern controversy and emerging successfully from the tests to which positivism and evolutionism will subject them. Our ethical teaching must be submitted to such tests. Instead of starting from stereotyped, traditional principles, which assume precisely what our present-day adversaries call into question, we must carry our analysis some steps farther back; we must check and supplement the data of consciousness by sociological and ethnographical observations; take account of the variations and weaknesses and failures of the moral sense or conscience in undeveloped or decadent societies: and carefully discriminate between the changeable and the unchangeable. The necessity of employing such methods of observation is still more manifest when we pass from the general principles of morals to their applieations in the sphere of natural right.

157. And in the first place we must have a proper understanding of the connection between natural or social right and the principles of general ethics. If, with Kant, we are to regard these two departments as entirely separate, the former dealing with man's interior, autonomous activity, and the latter with his external actions, including the conditions which safeguard the exercise of human liberty-then, obviously, natural right has no connection whatever

\footnotetext{
1 See some interesting pages from Sidgwick, pulblisherl in . Iind (April, Igor, p. 287), under the title: "Professor Sirlgwick's Ethical liew. An auto-historical fragment."
} 
with man's last end, nor does it impose any moral obligation upon him; its prescriptions in no way surpass the regulations of an ordinary police code.

Against such a weakly and demoralizing doctrine the foundations of our social rights and duties must be clearly shown to consist in the agreement of the known phenomena of social life and intercourse with the supreme and ultimate end of the individual man. It may be said with truth that there is a complete and absolute change from the traditional method of dealing with the great leading problems of social ethics : freedom of contract, organization of labour, property rights, education, the family, the origin, forms and limits of State authority, the relations of Church and State, international law, and the rights of war and peace. Not that these questions were unknown in the Middle Ages; but they were dealt with in a rather academic fashion, and solved on almost exclusively deductive lines, with only very rare attempts at applying the solutions to actual social conditions. Deduction can, of course, establish certain very general precepts of natural right (the prohibition of homicide, for example); but by itself it is helpless in presence of the highly complex and special ramifications of rights and duties in the various departments of modern life and intercourse. The historical and sociological sciences, so carefully cultivated in modern times, have proved to evidence that social conditions vary with the epoch and the country, that they are the resultant of quite a number of fluctuating influences, and that accordingly the science of natural right should not merely establish immutable principles bearing on the moral end of man but should likewise deal with the contingent circumstances accompanying the application of those principles. Our titles to private property and our methods of production have changed considerably since the thirteenth century ; St. Thomas' arguments 
in justification of the former have not the same, convincing force now as they had then. The investment of capital at interest, such a fertile source of production in modern conditions, is something very different from the usury that formed the object of long and bitter controversies in the Middle Ages. Then, also, ethnographical researches have brought to light many elementary forms of farnily life and domestic relations, differing widely from the type familiar to the Middle Ages. In a word, sociology mderstood in the wider and larger sense is transforming the methods of the science of natural right.

From all this the new scholasticism stands to gain, if it only avoids preconceived ideas, accepts all facts as they are brought to light, studies each question on its merits in the light of these facts, and not merely in its present setting but as presented in the pages of history. Boasting of this experimental method, systems like that of historical materialism have made pretence of revolutionizing natural right: and these must be fought with their own weapons. ${ }^{1}$

\section{SECTION 34.-LOGIC.}

158. Of all portions of ancient philosophy, the logic of Aristotle and the scholastics has best stood the shock of centuries. The end of the reign of Aristotle is not yet; men of the mental calibre of Kant have bowed in homage before him.

${ }^{1}$ Writing of the social ethics of scholasticism, M. Charles Gide says : "The renaissance of the Catholic teaching, even in its Thomistic torm, renders imperative at the piesent day a close study of those so-called fossil doctrines; and when they are brought to light one is astonished at their healthy and promising vitality, at their striking resemblance to many of our modern theories and at the insignificance of our attempts to improve on them." In the Revue d'économie politique, 1896, pp. 514-515 (ir propos of a work of M. Brants, Les théories économiques au XIIIe et au XI'e siecle). 
The new scholasticism will take up and transmit the best thought of the thirteenth century. But there is such a close connection between ideology and logic that the solutions offered in the former branch will necessarily influence those of the latter. The theory of abstraction underlies the scientific explanation of the mental act of judgment, for it is on abstraction that every intellectual act is based: without presupposing abstraction there can be no proper understanding of the categories and predicables, of the general mechanism of judgment, of the laws of syllogism and induction, of the nature of definition, division and demonstration, nor even of the bare notion of science.

But then, is there nothing new in the new scholastic logic? On the contrary. Since John Stuart Mill erected his logical system on the basis of a positivist ideology, all the laws of thought have been subjected to a searching analysis. The positivist resolves judgment into an association of sensations; the syllogism is either declared worthless (143) or reduced to induction; and the latter is a mere passage of thought from the particular to the particular. Definition, moreover, so far from forming the groundwork of the sciences, becomes a mere description of facts, and science itself is only a catalogue of stable associations between experienced sensations.

By the very fact of its close contact with positivism the new scholastic philosophy must of necessity emphasize and strengthen its vital theories. Thus it is that scientific induction, almost entirely neglected in medieval logic, has been established on a sound basis in order to secure it against the attacks that were being made upon it ; and the inductive methods, so ably outlined by John Stuart Mill, are now commonly adopted by scholastics. Credit is likewise due to him for a new classification of the fallacies. 
These are but a few of the points in which the new scholasticism has largely profited by contact with its adversaries.

Nowadays, more than ever, logic is proclaimed to be an instrument of knowledge. Shoholasties and positivists are at one in thinking that dialectic is not an end in itself. As one of the ancients humorously remarks: "those who stop in logie are like eaters of crayfish, who for sake of a morsel lose all their time over a pile of scales."

159. For some years past scientific method hats been the object of such careful and exhaustive study that it bids fair to be no longer a mere chapter in logie but an independent whole. We refer to the constructive or incentive methods (1:3), not to the methods of teaching: these latter belong nowadays to didactics (15\%). Under the title of methodology, or of applied logic. scholars are investigating the constitutive mothod of ach particular science: arithmetic, geometry, the calculus, ete, to mention a few deductive or rational sciences; physics, chemistry, biology, political economy, history, ete, to instance the inductive sciences of observation and experiment.

As for the method of philosophy itself, the combination of analysis and synthesis must ever remain a fortiori the soul of all philosophical effort, since this must ever aim at embracing in one comprehensive view (synthesis) the manifold departments (analysis) on the universal order $(4,48,120)$. 


\section{CHAP'TER III.}

\section{THE FUTURE OF THE NEW SCHOLASTICISM.}

\section{Section 35.-Conclusion.}

160. Were we to pursue the parallel established in the present volume between medieval and modern scholasticism, we should conclude by comparing the decadence of the former with the future of the latter. (Section 19). It is not, however, the object of the present section to indulge in prophecy, but rather to point to certain general conclusions which emerge from our investigations, and which, so far as we can judge to-day, are destined to influence the philosophy of to-morrow.

To take up the old scholasticism in globo, without changing anything, or adding anything, is simply out of the question. It is only the things of to-day that have an interest for the people of to-day: they will give their consideration only to what is modern. Hence, the "scholastic" thought-system must become "neo-scholastic" if it is to have life and influence in the modern world. That is to say, it must undergo a process of overhauling and resetting which will remove its medieval appearance and make it an attractive modern article.

But surely the modern spirit will kill the old philosophy instead of breathing a new life into it? Can we put new wine into old bottles? Will they not burst in the experiment? Well, we can test the tenacity of the old scholastic doctrines by carefully 
comparing them with their rivals of the present day. And the impartial testimony of enlightened and candid opponents will add some precious information to the results of such a comparison.

Besides the new scholasticism. two other great currents share between them all the philosophical systems of the opening century: Neo-Kantism and positivism. In these two latter currents it is easy to detect the influence of prolonged doubt about the existence of an absolute or noumenal reality. Neo-Kantism especially has exerted quite an extraordinary influence, both in Europe and in America, on the convictions of contemporary thinkers. They are all subjectivists of some shade or other: phenomenism has become a sort of atmosphere breathed by all modern thought.

Neo-Kantism and positivism are both alike met by the rational dogmatism of the new scholastic philosophy-the only one that merits serious attention among contemporary dogmatic systems. Inheriting as it does the traditional spiritualism of a Plato, an Aristotle, a St. Augustine and a St. Thomas, it bases its claims neither on the tradition which it perpetuates nor on arguments from authority-which can be twisted in opposite directions like the nose of a waxen image, to which it is quaintly compared by a thirteenth century scholastic, Alanus of Iille: auctoritas cereum habet nasum, id est, in diversum potest flecti sensum. On the contrary, it is after an examination of the facts that are engaging the attention of our contemporaries, after interpreting the results achieved by the sciences, and after testing critically its own principles, that the new scholasticism lays down its conclusions, and invites philosophers of the twentieth century to recognise them and deal with them on precisely the same titles as they deal with those of Neo-Kantism and positivism.

161. That it can rightfully claim to have such consideration accorded to it, its adversaries themselves 
admit. Men like Boutroux acknowledge that the system of Aristotle can compare advantageously to-day with Kantism and with evolutionism. ${ }^{1}$ Paulsen and Eucken regard the new scholasticism as the rival of Kantism, and describe the opposition of the rival systems as a war between two worlds (der Kampf zweier Welten)." "In the presence of such a striking and confident (siegesgewiss) forward march of medieval ideas, writes Mr. Doering, it will no longer suffice merely to ignore them, or to decline or stop short of questions of principles. The time has come for each to deliberately choose his attitude in regard to those principles and to raise aloft his banner." 3 Many, indeed, are the tributes paid by various other adversaries to the new scholasticism, but it would be both superfluous and needless to reproduce all of them here. ${ }^{4}$

162. If we record such testimonies here at all it is firstly in order to show how absurd is the attitude of those numerous sceptics who condemn without hearing and mock at what they do not understand. And it is secondly in order to persuade those of our friends who are impatient for the rapid and sweeping triumph of our philosophy, that success must not be expected from extrinsic factors only, but must always be the crown and the result of real doctrinal superiority. Leo XIII. did not create the merit of the new scholasticism by virtue of a decree, but he understood its merit and saw his opportunity.

1 Aristote, Études d'histoire de philosophie (Paris, I901), p. 202.

"Eucken, Thomas von Aquino und Kant. Ein Kampf zweier Welten (Kantstudien, Igor, Bd. VI, h. I). Paulsen, Kant, der Philosoph des Protestantismus (ib. 1899). The latter study, being conceived from the religious point of view, is of less importance from the point of view of the present work.

${ }^{3}$ Doering. in the Zeitschr. f. Psychol. u. Physiol. d. Sinnesorgane, 1899 , pp. 222-224, in a review of Mercier's Origines de La Psychologie contemporaine.

"See, for example, Mercier's Origines, etc., ch. viii : "Le neo-Thomisme"; and the Revue Néo-Scolastique, I\$94, pp. 5 and foll., and under the heading: Le mouvement neo-thomiste. 
262 THE FUTURE OF THE NEW SCHOLASTICISM -

His energetic words may have hastened the dawn and added to the renown of the new scholastic philosophy: but they could never have given its doctrines an abiding and recognised authority did not these doctrines themselves give evidence and promise of a deep and vigorous vitality.

They will prevail, as the truth prevails; but their growth will be progressive, and always conditioned by the general level of man's intellectual acquirements. In this respect the new scholasticism is self-moving like every living thing; a stop in its evolution would be the symptom of another decay. 


\section{APPENDIX.}

\section{PHILOSOPHY AND THE SCIENCES AT LOUVAIN. ${ }^{1}$}

The rise and progress of the new Scholastic Philosophy at the Catholic University of Louvain, in Belgium, during the past twenty years, has attracted the attention of philosophers of every school and every shade of opinion. ${ }^{2}$ It marks an epoch in the history of Modern Philosophy, and it contains many important lessons for all who take an interest in the progress of thought, especially among Catholics. In the following pages we shall aim at giving a very brief sketch of the spirit that animates the work that is being done at Louvain in the department of Philosophy, and at conveying some idea of the significance and influence of the new movement. We have been already endeavouring to show how Scholastic Philosophy, subsequent to the rise of Cartesianism, became divorced from the Natural Sciences, to the great detriment of both, and of the Catholic religion as well, ${ }^{3}$ and how Leo XIII sought, with all the power of a great mind, to repair the damage done, or at least

\footnotetext{
${ }^{1}$ Reprinted, with some minor alterations and omissions, from the IRISH Ecclesiastical Rr.corv. May and June, 1905.

${ }^{2}$ Cf. L'Institut Supérieur de Philosophie a L'Université Catholique de Louvain (I890-1904). by Rev. A. Pelzer, D.Ph. (30 pp.; Imprimerie Folleunis et Ceuterick, 32, rue des Orphelins). Le Mouvement NéoThomiste (16 pp.), extrait de la Revue Néo-Scolastique, publiée par la Societé Philosophique de Louvain. Directeur: D. Mercier. Secretaire de Redaction: M. De Wulf. (Institut Superieur de Philosophie, I, rue des Flamands, 1901). Deux Centres du Mouvement Thomiste ; Rome et Louvain, par C. Besse. (63 pp. : Paris, Letouzey et Ané, 17, rue du Vieux-Colombier, 1902). Rapport surles Etudes Superieures de Philosophie, presenté par Monseigneur D. Mercier au Congrès de Malines, 1891. (Louvain, Librairie de l'Institut de Philosophie, Louvain, I $891,32 \mathrm{pp}$.)

${ }^{3}$ I. E. ReCord, January, 1906.
} 
to prevent a continuance of it, by renewing once more the long shattered alliance. ${ }^{1}$.

I. - THE PROJECT OF A PHILOSOPHICAL INSTJTUTE AT

\section{LOUVAIN.}

It was Leo XIII himself who conceived the project of founding a special Institute for the study of Scholastic Philosophy in close connection with the sciences in the Catholic University of Louvain. During the time he had been Papal Nuncio in Belgium he had learned to esteem and admire the splendid work done in every department of education by the Louvain professors, lar and clerical alike. ${ }^{2} \mathrm{He}$ felt that a centre of such scientific renown, such intellectual activity, and such frank and fearless Catholicity, would be just the fittest place in the whole Cathelic world to wed once more the old Scholastic Philosophy with the progressive Modern Sciences. The idea of the possibility of such a union gave a severe shock, no duubt, both to timid Catholics on the one hand, and to agrgressive infidels on the other. But Leo XIII knew Scholastic Philosophy, and knowing it he had confidence in its harmony with scientific truth. Fortunately, too, he found men in Belgium ready to share that confidence in the fullest, to take up his project with ardour, and to carry it through many difficulties and much opposition to the well deserved success which it enjoys to-day. We allude especially to the illustrious Cardinal Archbishop of Mechlin, Cardinal Mercier, founder of the Louvain Philosophical Institute. He was Professor of Philosophy

I I bid., lebruary, I006.

2 The professors are, of course, all Catholics. They number over one hundred. About two-thirds are laymen. Some priests are to be found in all the faculties. In the appointment-whether of clerics or laicsmerit alone is looked to. Over 2.000 students-all Catholics-frequent the University. 
in the Petit Seminaire of Mechlin, when, in 1880, he was called to Louvain to fill the new chair of Thomistic Philosophy established at the University in obedience to the wishes of Leo XIII. ${ }^{1}$ The establishment of this chair only prepared the way for a larger scheme. Eight years afterwards, in July, 1888, the Pope evidently considered that the time was ripe for founding a special Institute. In a Brief to Cardinal Goosens, Archbishop of Mechlin, he unfolded his plans. "It seems to Us useful and supremely advantageous," he wrote, "to establish a certain number of new chairs so that from these different departments of teaching, wisely and harmoniously bound together, there may result an Institute of Thomistic Philosophy, endowed with a distinct existence." More than a year afterwards, when some attempt had been made to carry out the Pope's wishes, and want of funds proved the greatest obstacle, Leo XIII came to the rescue with

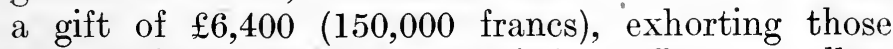
engaged in the work to use their best efforts to collect the necessary balance from all friends of education in Belgium. That he was determined to have the good project carried out is evident from these further words of his in a Brief of November, 1889 :

"We consider it not only opportune but necessary to give philosophical studies a direction towards nature so that students may be able to find in them, side by side with the lessons of ancient wisdom, the discoveries we owe to the able investigations of our contemporaries, and may draw therefrom treasures equally profitable to religion and to society."

It is easy to recognise in those words the predominant idea that runs through the whole Encyclical Eterni Patris : that Scholastic Philosophy must be taught in close conjunction with all the neighbouring

${ }^{1}$ Brief of December 25th, 1880, to Cardinal Dechamps, Archbishop of Malines. 
natural and social sciences if it is to come out into the open and vindicate for itself_-as it ought--an honourable place amongst the thought-systems that agitate the scientific, social and religious worlds in the twentieth century. That idea was taken up and developed by Mercier and his friends at Ionvain, with a largeness and liberality of view and with an amount of zeal and devotedness which we look for in vain even in Rome itself. Speaking of the Institute in those days of its infancy, the Abbs Besse writes :-

"A new force born of the soil, so to speak, gave it life. To its director is due the credit of having first maintained, then emphasized, enlarged and developed the programme and project of the Pope: and, finally, of having created a Thomism which, while devoid of all Roman initiative and imitation. has nevertheless given to the Pope's ideal a more decided realization than it ever achieved in Rome." ?

The appeal for funds to go on with the work met with a response which, if slow at first, was on the whole generous. The Belgian Catholics have to bear a heavy financial burden for the annual upkeep of such a vast university as Louvain. But as the are fully alive to the importance of education, large gifts, often anonymous, unexpected, providential, are usually forthcoming to tide any worthy educational enterprise over its financial difficulties. The foundation and equipment of the Philosophical Institute was not unduly delayed for want of funds.

But there were other difficulties and disappointments, enmities and oppositions, such as are incident to the undertaking of any great and difficult work. To these we shall return later on. They persisted long enough to break the spirit of anyone less hopeful and persevering than Mercier. However, they gradually diminished with time, and the Institute began to show signs of a vigorous and flourishing

${ }^{1}$ Deux Centres, ctc., p. 3 R. 
life. God's blessing was with the good work. Mercier's manifest sincerity, his zeal in the cause of truth, his many admirable qualities of head and heart enabled him to overcome all opposition and win the respect of all. He enjoyed the fullest confidence of Leo XIII, ' and had the pleasure of hearing the holy Pontiff publicly praise and recommend the work of his (Leo's) Institute-the Pope might have said their Institute-as lately as the year 1900." To-day the Louvain Philosophical Institute wins the respect and esteem of every impartial visitor. Not indeed that it is yet quite fully equipped and organized, or perfect in every detail, but that it is so far a decided success, an institution that is doing a vast amount of solid, substantial work of a very superior and highly creditable sort. It is training professors of Philosophy not only for Belgium, but for many seminaries, colleges and universities all over Europe and the English-speaking world; and it is giving them a training which, it is our honest belief, cannot be equalled elsewhere. It is only the bare truth to say that "if we find engineers who would wish to have studied at Zurich, doctors who would wish to have been through the Pasteur Institute, theologians who matriculate in the University of Tübingen, it seems that it is towards the Institute of Louvain that our young philosophers ought in future to direct their steps." ${ }^{3}$

${ }^{1}$ We are glad to be able to state that the present supreme Pontiff, Pius X, is altogether of the same mind towards the Neo-Scholastic Philosophy and the Louvain School. In a Brief to Mgr. Mercier and the masters and students of the Séminaive Léon XIII, dated June 20th, 1904, and published in the August number of the Revue Néo-Scolastique, the Holy Father speaks in the highest terms of the Institute and its work. He thanks God for blessing the project of his predecessor in founding the Institute, and exhorts teachers and students alike to continue their noble work: "Minime dubitantes quin in Nobis, apud quos benemeritum Institutum vestrum plurimum valet, et singularis gratiae et benignae voluntatis ii nunquam, desiderentur sensus, quibus ipse Decessor Noster vos enixe est prosecutus."

2 Discourse of Leo XIII to the Belgian Pilgrim.s, December $30 t h, 1900$. Revuc Néo-Scolastique, February, I901, pp. $84-85$.

${ }^{3}$ Deux Centres, etc., p. 3. . 
With such a general knowledge of the Institute, derived as it were from without, we are now in a position to examine more closely the spirit which, from the outset, animated its inner life and working. What is really most accountable for the remarkable success of the Institute is

\section{II.-THE SPIRIT THAT ANIMATES PHLLOSOPHICAL STUDIES AT LOUVAIN.}

We can find no more authentic exponent of that spirit than Ilereier himself. He was invited by the Cardinal-Archbishop of Mechlin, Cardinal Goosens, to give an exposition of the leading ideas of the projected Papal scheme, before the "Higher Education Section" of the Congress held in that city in 1891. He did so in a very remarkable Rapport sur les Etudes supérieures de Philosophie.

Commencing with the observation that "Catholics live in a state of isolation in the scientific world," he went on to seek the causes of that isolation, fatal alike to science and to religion. Apart from the systematic opposition of some scientists to everything Christian, he set down as a leading cause of the phenomenon the widespread prevalence amongst non-Catholies of a preconceived idea that we Catholics are always engaged in preoccupations subservient to the defence of our faith :-

"Yes [he continues] the idea is widely entertained that the Catholic savant is a soldier in the service of his faith, and that, in his hands, science can be nothing but a weapon for the defence of his credo. In the eyes of many he would seem to be always under the bolt of a threatened excommunication, or shackled by troublesome dogmas; and to remain faithful to his religion he must apparently renounce all disinterested attachment to the sciences and all 
free cultivation of them. Hence the distrust which he encounters. A publication coming from a Catholic institution-Protestant institutions are judged more favourably, no doubt because they have given proofs of their independence by their revolt from authority -is treated as a plea pro domo, as an apologetic which can have no right or title to an impartial and objective examination."

Such is the great current misconception of the Catholic attitude towards science in the minds of non-Catholics. To remove this misconception must be our first aim in the future scientific and philosophic education of our Catholic youth. Then, side by side with this misconception, and perhaps to some extent the cause of it and of the consequent ostracism of Catholics from the world of science, there is another misconception-in the minds of Catholics themselves - the mistaken view which a large number of Catholics have about science.

"For them science consists in learning and collecting results already achieved, in order to synthesize them under the conceptions of religious faith or of some spiritualist metaphysic. Contemporary science has no longer such comprehensive aims or synthetic tendencies; it is, before all, a science of partial, minute observations, a science of analysis.

"From that diversity of point of view in the way of looking at science results this consequence: that Catholics resign themselves too easily to the secondary róle of mere retailers of science; too few of them have any ambition to work at what may be called science in the making; too few aim at gathering and moulding the materials which must serve in the future to form the new synthesis of science and Christian philosophy. Undoubtedly this final synthesis will harmonize with the dogmas of our Credo, and with the fundamental principles of Christian wisdom; but while waiting till that harmony shines 
forth in its full light, the objections raised by unbelief conceal it from the eyes of many, and because our champions are not always there to give back with recognised competence and authority the direct and immediate answers which these objections call for, doubts arise and convictions are shaken; the materials are grouped, arranged, and classified without us, and too often against us, and infidelity monopolizes for its own profit the scientific prestige which should be made to serve only the propagation of truth."

We would fain believe that the above picture is somewhat overdrawn, but we fear it fairly represents what was the real state of affairs when Mercier proposed the remedy which he has been ever since carrying out with such gratifying results. That remedy he outlined in these very explicit terms :-

"To form, in greater numbers, men who will devote themselves to science for itself, without any aim that is professional or directly apologetic, men who will work at first hand in fashioning the materials of the edifice of science, and who will thus contribute to its gradual construction; and to create the resources which this work demands: such at the present day ought to be the two-fold aim of the efforts of all who are solicitous for the prestige of the Church in the world and for the efficacy of its action on the souls of men."

So far this one idea stands out prominently : that if the Catholic is to be heard and respected in the world of modern science and modern philosophy he must be taught to cultivate those studies for their own sake, and not with any conscious, intended dependence on dogma, nor with any direct subservience to apologetical ends.

But to find the resources for forming Catholic youth on those lines in the sciences is no easy matter. And to give them such a formation in philosophy seems more difficult still; for the latter presupposes 
the former discipline: nemo metaphysicus qui non prius physicus. Mercier in nowise minimises these difficulties: he gives quite a luminous view of all that such a programme would include :-

"There is question of giving to the Church workers who will break the soil of science as of old the monks of the West broke the virgin soil of Christian Europe and laid the foundations of the material civilization it enjoys to-day; of showing the respect of the Church for human reason, and the fruit she expects from its work for the glory of Him who has proclaimed Himself Master of the Sciences.

"An immense field is open to scientific investigation. The boundaries of the old philosophy have become too narrow : they must be extended. Man has multiplied his power of vision; he enters the world of the infinitely small and fixes his scrutinizing gaze upon regions where our most powerful telescopes discern no limits. Physics and Chemistry progress with giant strides in the study of the properties of matter and of the combination of its elements. Geology and Cosmogony reconstruct the history of the formation and origins of our planet. Biology and the natural sciences study the minute structure of living organisms, their distribution in space and succession in time; and embryogeny explores their origin. The archæological, philological, and social sciences remount the past ages of our history and civilizations. What an inexhaustible mine is here to exploit, what regions to explore and materials to analyze and interpret; finally, what pioneers we must engage in the work if we are to gain a share in all those treasures!

"It is imperative, therefore, that in those different domains we should have explorers and masters who, by their own activity, by their own achievements, may vindicate for themselves the right to speak to the scientific world and to be heard by it; then we 
can answer the eternal objection that faith blinds us, that faith and reason are incompatible, better far than by abstract principles, better far than by an appeal to the past: we can answer it by the stubborn evidence of actual and living facts."

But if it is important for the Church to have Catholics as scientists, it is far more important for her to have Catholic scientists who will be also philosophers:-

"If we must devote ourselves to works of analysis we must remember-experience has only too clearly shown-that analysis left to itself easily gives rise to narrowness of mind, to a sort of instinctive antipathy to all that is beyond observed fact, to positivist tendencies, if not to positivist convictions.

"But science is not an accumulation of facts, it is a system embracing facts and their mutual relations.

"The particular sciences do not give us a complete representation of reality. They abstract: but the relations which they isolate in thought lie together in reality, and are interwoven with one another; and that is why the special sciences demand and give rise to a science of sciences, to a general synthesis, in a word, to Philosophy.

"Sound philosophy sets out from analysis and terminates in synthesis as its natural complement. Philosophy is by definition a knowledge of the totality of things through their highest causes. But is it not evident that before arriving at the highest causes we must pass through those lower ones with which the particular sciences occupy themselves?

"At the present day, when the sciences have become so vast and numerous, how are we to achieve the double task of keeping au courant with them all, and of synthesizing their results? That difficulty is a grave and delicate one.

"Since individual courage feels itself powerless in presence of the field of observation which goes on 
widening day by day, association must make up for the insufficiency of the isolated worker; men of analysis and men of synthesis must come together, and form, by their daily intercourse and united action, an atmosphere suited to the harmonious development of science and philosophy alike. Such is the object of the special School of Philosophy which Leo XIII, the illustrious restorer of higher studies, has wished to found in our country and to place under the patronage of St. Thomas of Aquinthat striking incarnation of the spirit of observation united with the spirit of synthesis, that worker of genius who ever deemed it a duty to fertilize Philosophy by Science and to elevate Science simultaneously to the heights of Philosophy." 1

We find condensed in the above passages_-glowing as they are with the eloquence of one inspired with a noble zeal in the cause of truth-an exalted and true conception of the scope and mission of philosophical training; a faithful and enthusiastic reiteration of Leo the Thirteenth's bold and outspoken ideas on the close and intimate relations that ought to exist between Science and Philosophy ; a clear understanding of the need to bring together those various studies into one and the same educational centre; an implicit confidence that true Science and true Philosophy would and should harmonize with each other and both alike with the Catholic Faith; and a frank and open assertion, based upon that very confidence, that in Schools of Science and of Philosophy those subjects should be taught to our Catholic youth without any view to apologetics, but simply and solely for their own sakes-that the teaching and learning of those branches, to be successful, must be disinterested.

\footnotetext{
1 The above passages from Mercier's Rapport are all translated from the various pamphlets enumerated at the head of this Appendix.

${ }^{2}$ Vide I. E. Record, February, 1906.
} 
In order to re-establish more effectually the long superseded alliance between Scholastic Philosophy and the Sciences, Mercier found it necessary to insist most emphatically that this Philosophy was far more than what many Catholies had come to consider it-a mere intellectual discipline subsidiary to Supernatural Theology - that in the presence of that Theology, from which it received such illumination, and to which it could never rum comnter, it was itself an independent and antonomous science, based upon all the natural sciences of observation and experiment.

"No one [writes the Abbé Besse] could mark off more clearly the respect we owe to theology, from the liberty we retain in science. Hercier here admirably lays down the a priori rights of nature and of grace. It is just because he is quite certain that grace never will be wanting to the sincere scientist that he is himself a sincere and disinterested scientist abstracting from grace. ${ }^{1}$

But how were all these views and projects of Mercier received when they were first put forth by him? Like everything that sounds novel-not without suspicion. Was Philosophy, then, really based on the sciences, and were Catholic philosophers to be obliged to take account of what was going on in the scientific world? Was not Catholic Philosophy something far above such commerce with the "things of earth"? Was it not a pure intellectual system subservient only to the noble Queen of Sciences; Philosophir ancilla Theologice? What could it have to do with laboratories and dissectingrooms? So argued the Catholic advocates of the status quo-philosophers and the scientists alike. There had been already a struggle in Rome between the old ideas and the new before the latter got a locus

${ }^{1}$ Deux Centres, ctc., p. 4 $\mathrm{r}$. 
stand $i$ in the schools. At Louvain the same struggle was fought over again, only with greater success in the issue. The scientists were at first inclined to look askance at what they considered an unwarrantable sort of dilettante dabbling in laboratories on the part of those young philosophers; and to hold aloof rather than co-operate. Those of the philosophers who were not radically opposed to the new departure expressed their fears that the neo-Thomists were going far beyond the Papal wishes, if not in direct opposition to them. In reality the disobedience lay with those who, clinging to the letter, neglected the spirit of the Papal reform :-

"There was no excuse for their having denounced the work of Louvain as a work of 'discord' and of 'disobedience,' nay, even of 'treason.' The truth is that Mgr. Mercier was . . . the most comprehensive admirer of the idea of Leo XIII. But if he has directed it entirely towards the twentieth century, if he has instinctively put it into the thick of the contemporary conflict, thus making it actual and living, if he has transported it into the ragion of proof and criticism, giving it that attitude of confidence and boldness in presence of the revelations of experience and the warnings of science, all this was neither a wilful misreading of the Papal wishes, nor a pretence, nor a betrayal, but the steady march of a mind that believed the Pope as it did the truth, and that ennobled and honoured the Papal directions while submitting to them."

J Deux Centres, etc., p. 6o. The writer of the articles reprinted in this brochure, draws a contrast between the two centres of the Neo-Scholastic movement,--Rome and Louvain. He says that Leo XIII. probably never meant to establish at Louvain anything more than a "Roman College" on the lines of Cornoldi's school at the Gregorian University in Rome. That may be-and certainly such a college would have been a failure at Louvain ; but, whatever Leo's intention in the beginning may have been, it seems certain that Mercier's larger and bolder work has been thoroughly in the spirit of Leo's ideas, and has always had the warm sympathy and support of the late Pontiff. Nor is there much room to doubt that Louvain has been hitherto more successful than Rome in teaching, modernizing, popularizing, propagating the Philosophy of the Schools on the lines indicated by Leo. In 
Mercier succeeded in putting Philosophy at Louvain "into the thick of the contemporary conflict" between the various modern systems and sciences, and he did so because, from a deep and masterly study of the Scholastic Philosophy in the light of Modern Science, he was convinced that he saw $a$ substantial harmony between the fundamental principles of the former and the established conclusions of the latter.

It was in the various non-Catholic camps of modern Science and modern Philosophy that this vigorous action of Mercier's, in giving expression to the projects of Leo, produced the greatest comment and the most profound sensation. The idea that Catholics could be disinterested scientists seems to have been regarded - then as now-by many unbelieving scientists as a good joke. The determination with which Mercier and his Neo-Scholastic friends kept insisting that they could and would train disinterested scientists and disinterested philosophers in the very heart of a Catholic University; that they meant to "substitute for the existing patched up peace between Science and Faith, an agreement that would be steady and yet progressive, interior and regular ;"1 - that determination made unbelievers impatient

that sense the contrast drawn by the Abbé Besse-an earnest admirer of the Louvain Institute - is quite justifiable. But it is also only fair to observe that the success of the Louvain Institute is largely due to a combination of favourable surroundings which the movement in Rome did not enjoysuch, for example, as the presence of flourishing faculties of Science and Medicine, etc.. with the ablest professors to give special courses in the Philosophical Institute; the presence not only of the best lay professors to teach, but of the best lay students to frequent the courses of the Institute in company with the ecclesiastics; the presence of well equipped laboratories; the employment of the vernacular in all their teaching; the fulness and variety of that teaching throughout a three years' course; the superiority of their staff in numbers and in qualifications; the life and reality infused into their studies by their attention to the current periodical literature in the various departments; the great intellectual activity and general scientific prestige of their University. These circumstances-partly, no doubt, of their own making at Louvain-have already placed the Philosophical Studies of the Institute on that higher level which the Roman professors have been strenuously endeavouring to reach.

${ }^{1}$ Deux Centres, etc., p. 43. 
and then afraid, lest after all there might not be some danger that the Catholics might succeed, and the infidel monopoly of "Modern Science" and "Modern Philosophy" be unceremoniously interfered with.

But then the idea of a "Scholastic" revival in Philosophy, of a "Thomism" that would be "scientific"! That, of course, appeared nothing short of ludicrous to the enlightened Moderns in their blissful ignorance of what Medieval Philosophy was and what it contained! For, what was Medieval Philosophy to them? It was a vast fabric of errors -multiplied and monumental-of errors that were grotesque in their puerility, and of distortions of fact that were hoary with age; such was the idol that passed for Medieval Philosophy-for Scholasticism-in the minds of "the moderns," and that stood unassailed until recent critical researches into the history of that period demolished the idol by shedding forth a light before which it has crumbled into dust. Those historical studies in Medieval Philosophy_-so sadly needed in order to do justice to Scholasticism in the eyes of the modern worldwere then and are still being carried on partly in Germany, partly in Paris, and partly in Louvain. The prominence given to the History of Philosophy is one of the features of the Neo-Scholastic programme of studies at the Louvain Philosophical Institute. Thanks to the very great progress that has been made in that department, the moderns are now willing to recognise that Medieval Thomism was after all something other than a tissue of barren speculations and empty formalisms; that the great scholastics were not "a crowd of dogmatic idealists trying to construct a world out of the categories of speech" $;{ }^{1}$ that they were by no means disdainful of the observation of facts ; that, on the contrary, they were great men and great philosophers who

${ }^{1}$ Deux Centres, etc., p. 45. 
have been much misrepresented; that their system of philosophy had been travestied and distorted, and then ignorantly ridiculed by the heralds of our "Modern Philosophy": that. in fine, its latest presentation to the modern world at the hands of the Neo-Scholastics-in its proper historical setting, and in close contact with the modern sciencespoints to this conchusion. that amongst all the philosophical systems in rogue at the present day. the modern Scholastic: Symthesis. on the lines of Aristotelian Animism. is most in hurmony with the conchusions and tendencies of morlem phigsical science. Some of the most distinguished scientists have explicitly avowed that greater hamony between Science and Scholasticism. ${ }^{1}$ Catholic sciontists can have no difficultr about it - it is onl what the should expect -but for many non-Catholic scientists such a revelation must be not a little startling.

In the ranks of the Catholic exponents of the traditional Scholastioism the idea of a close alliance between the natural sciences and their secluded system was looked upon with doubt and suspicion. They could not with any good grace oppose the new project; for they. too. professed to believe that in Scholasticism there lar concealed in some mrsterious way a vast treasure of doctrine that could easily put to flight the impious modern scientist. But they shrank from putting it to the test. They were apparently content to guard their "hidden treasure" and express a pious opinion about its efficacy. They would not ransack it in order to bring forth from it "new things and old."

The fact is that those philosophers did not appreciate the value of the legacy that was bequeathed to them from the golden age of Scholasticism-and that for two reasons: because, firstly, they had

${ }^{1}$ As, for example Wundt in Germany. 
followed the tradition of neglecting the history of Philosophy-even of the system they studied; and secondly, and consequently, they had more or less fallen a prey, quite unconsciously, to the ultraspiritualist views and tendencies of post-Cartesian Philosophy.

In the first place, down to very recent times the history of Philosophy was entirely neglected, even by philosophers themselves. Those most devoted to Philosophy were least devoted to its history. Innumerable errors about systems and doctrines were the inevitable result. False theories and opinions crept into systems and became incorporated with them even in the hands of the traditional exponents of those systems : witness the false doctrine of the migratory species impressa, and other postRenaissance theories, that vitiated and discredited later-day Scholasticism. It required the work of such recent pioneers in the history of Medieval Philosophy as De Wulf, Baeumker, Ehrle, Denifle, Mandonnet, Picavet, Clerval, to make even a beginning in dissipating those errors. If the traditional exponents of Scholasticism had only attended a little to its history the Neo-Scholastics of to-day would not have experienced so much trouble in giving to the world the authentic philosophical teaching of the thirteenth century-nor so much opposition in proclaiming an alliance between it and the findings of modern science. Unfortunately historical studies had not been in vogue in any department of learning. Even Catholics, though so largely dependent on Tradition in matters of Faith and Theology, which their philosophical studies always subserved, had nevertheless developed no special leaning towards historical criticism of the sources and development of their great deposit of Revealed Truth. One would have expected some such development; for, what is Tradition without History if not a mere empty 
formula? The Abbé Besse writes some hard things about modern Scholastics who would continue, even in the present age of historical research in every department, irrespective of its history, to teach Scholastic Philosophy as of old.

"Defenders of Tradition, they have become its prisoners, and not a little blindly-seeking to know it only in its official framework. They are destitute of the historical sense. They are unaware of all that is to be gained by an intimate acquaintance with the milieu of facts and ideas that accompany each step in the progress of systematization, and each new contribution to clearness of terminology. Their philosophy has neither topography nor chronology. It is of no age. It seems to issue from the night only to plunge into it again. That is undoubtedly the secret of the ennui that results from reading their amorphous pages. Fearing, as it were, to disturb the soul in its pure contemplation of ideas they have shut it up in a cavern."

In the second place inattention to the historical sources and growth of Scholasticism left its modern exponents open to the danger of unconsciously misconstruing its whole method and spirit. It was inevitable that the exaggerated spiritualism introduced into Philosophy by Descartes should issue later on in two distinct currents of idealism and materialism. The Scholastics naturally fell under the influence of the former current in opposition to materialism. Then, also, Descartes had unduly emphasized the use of the deductive method and created a chasm between Philosophy and the Physical Sciences. Again the Scholastics followed in the same direction; all the more easily because the Physical Sciences soon afterwards claimed a monopoly of the newly "invented" inductive method," and

1 Which had been employed by Roger Bacon, Albert the Great and Thomas of Aquin centuries previously. 
identified themselves with materialism. And so Scholasticism in the second half of the last century found itself in a condition, of which the following paragraph gives a striking picture :-

"Catholics for a long time have seen their only safety in this divorce of speculation from science. The more Philosophy developed in that direction the more they felt at ease with it. They remained content with the sound of certain familiar words, such as: God, the infinite, the perfect, the good and the beautiful, the ideal, etc. In that effort to escape all concern in the science of material things they saw a token of moral elevation, something of that good taste of which the poet speaks :

\section{Coetusque vulgares et udam Spernit humum fugiente penna.}

What an illusion! It was thus that Philosophy came in for the staggering blows of the school of Taine, and of science in general after him."

Now this false spell of Cartesianism had to be broken by once more establishing Scholasticism on the basis of the Physical Sciences; and the way had to be cleared for this reform by the historical criticism that would show how completely, such reform would harmonize with the true spirit of the great Medieval Scholastics :-

"To historical criticism is due the credit of having re-established the truth. On that point doubt is no longer possible. Mercier speaks like our best historians of Philosophy, like Boutroux, Brochard, Picavet. Aristotle had the true method and spirit of science. With him it was, of course, incomplete; even erroneous on many points. Instead, therefore, of despising it we should have corrected it. We should have freed it from its faults, its limitations,

${ }^{1}$ Deux Centres, etc., p. 50. 
its shortcomings. We should have completed it. Above all, we should have transformed it according to the new methods of observation and experiment. And so we should have avoided that conflict between science and metaphysics which is the greatest conflict of modern times. ${ }^{1}$

But yet another obstacle was raised by the defenders of the old Scholasticiom, another attempt to forbid the banns between sicience and Philosophy : a final fear was expressed by them for the stability and definitiveness of any superstructure of lletaphysies reared on the shifting and progressive basis of Physics. How can such Metaphysies have any pretensions to finality, if they partake of the nature of hypotheses based upon the observation of nature? This apprehension for the immutable truth of Metaphysics was genuine and sincere. But it was an apprehension for which the alliance of Metaphysics with Physics could give no grounds: because. in any case, in so far as Hetaphysies is endowed with any positive, real content, it is dependent, for that content. upon the domain of Physics where it gets all its "raw material" so to speak. And it must rest content with this raw material, such as it is, and take it for what it is worth.

"It is by the employment of hypothesis that the philosopher attempts to establish an order and $a$ hierarchy in that heterogeneous mass. But he knows that he is quite exposed to see the explanatory principle he has discovered declared at any time useless. Hence it is that we cannot exercise too much patience in waiting before we attempt to open a parley with that invisible basis of all things, that hidden god which, like the other God. no doubt, enlightens the timid and blinds the daring."

\footnotetext{
${ }^{1}$ The conflict between science and faith is oniy one particular aspect of it. (Besse : Deux Centres, etc., pp. 49, 50.)

${ }^{2}$ Ibid., p. 48 . :
} 
But how long, then, are we to give in to this "timidity"? To content ourselves with the experimental and inductive side of things before attempting any comprehensive synthesis? Are we to postpone our Metaphysical Synthesis of things until we can make it, once for all, absolutely definitive, after the physical exploration of facts is completed-that is, indefinitely? Or are we to make it independently of Physics altogether? Or are we to moke an incomplete and perfectible working synthesis, based on the actual state of Physics, and progressive as the latter? Not the first nor the second alternative, but the third must be chosen. Not the first evidently, for no matter how men may pretend to despise Metaphysics they cannot and will not get on -it is not in human nature to get on-without Metaphysics of some sort. Not the second, for such a Metaphysic would be nothing better than an empty formalism woven from man's innér consciousness. Therefore the third, imperfect as everything else that is human, must satisfy us in this world of second-bests.

"In short, one or other of two things: either after the scientific progress realized since the time of Aristotle the investigation of facts can be allied with the work of a dogmatic elaboration, or such elaboration will be indefinitely retarded. In the first case some at least of our preconceived errors can be rectified, some at least of our uncertainties settled; in the second case, such elaboration, even though neither definitive nor absolute in its conclusions, should be outlined nevertheless, and in spite of the risks. It would be unstable, like science, but like it, too, progressive. When Metaphysics is made to spring from Physics, Metaphysics has just the same value as Physics. Approximative and provisional as it is, at all events it contains the positive, the real, the actual. But all that-is THE TRUE. 
This point of view which surpasses in extension, while interpreting and following, that of Aristotle and the School, is perhaps the only reasonable one." I

\section{III.-INFLUENCE OF THE LOUVAIN SCHOOL OF} PHILOSOPHY.

It is from that point of view that Scholastic Philosophy has been taught at Louvain for now nearly a quarter of a century. The principles on which their whole method is based at the Philosophical Institute appear to us to be thoroughly sound; and that they are practical and fruitful is abundantly proved by the ample measure of success that has resulted from their adoption. The Louvain Institute has attracted the close attention of contemporary philosophers of every shade of opinion, not only all over the Continent, but all over the English-speaking world as well. It reflects credit on Catholic Belgium, and deserves well of all Catholies for having renewed, as it were, and re-invigorated Scholastic Philosophy. It is giving that Philosophy a new place--and an honourable place-in the history of Philosophic Thought at the dawn of the new century.

The widespread publications of the Institute have drawn to that Philosophy the serious attention of scientists who had at first been inclined to ask: "Can anything good come out of Galilee?" Some of them already recognise in that venerable system a via media, equally removed from the erroneous extremes of Cartesian Spiritualism and Modern Materialism, and more in harmony than either with the results of modern scientific research. That the NeoScholastic Philosophy has to be counted with in the world of modern Philosophical Systems is altogether evident from even a cursory acquaintance with the

${ }^{1}$ Deux Contres, ctc., p. 51. 
Philosophical periodicals on the Continent. It is not merely in the Catholic reviews but in those of every shade that we find Neo-Scholasticism discussed -favourably or adversely as the case may be. That it should be met with in such publications as the Revue Thomiste, the Divus Thomas, the Année Psychologique, the Revue de Philosophie, the Philosophisches Yahrbuch, the Yahrbuch fïr Philosophie und Speculative Theologie, the Beiträge zur Geschichte der Philosophie des Mittelalters, the Historisch-Politische Blätter für das Katolische Deutschland, the Ciudad de Dios, the Revista Ecclesiastica, the Era Novella, etc., is, perhaps, in no way remarkable, for those are Catholic publications'; but the large amount of attention it receives from time to time in such Philosophical reviews as the Kantstudien, the Zeitzschrift für Psychologie und Physiologie der Sinnesorgane, the Revue de Metaphysique et de Morale, the Revue Philosophique, the Revue Internationale de l'Enseignement, the Revista Filosofica, the Revista Critica, etc. - shows very plainly that the influence of the new school of Philosophic thought at Louvain has made itself felt far and wide. Wherever its tenets are attacked it is not wanting in champions able and willing to defend it in a thoroughly scientific and scholarly manner. Even where it is controverted it is respected and wins esteem for its adherents.

In brief, it bids fair to win, if indeed it has not already won, an honourable entrée into the vast arena of Modern Philosophy. Of this providential fact, what the ultimate significance may be, whether for Science, for Philosophy, or for Religion, it would be hard to say. So far at any rate the new Scholasticism has been shedding upon the natural sciences a flood of light which they had been seeking in vain from the competing philosophies; it gives promise of interpreting and complementing them in such an eminently rational manner as to justify its claim to 
be not merely a philosophy amongst many philosophies, but to be the True Philosephy.

We have been living through an age of negative Philosophy, and have witnessed the spread of "cowardly" Agnosticism. We have watched that philosophy confess with false humility that it "could know pratetically nothing": an appropriate anticlimax to the soluere whenes it had sprung-the Rationalism that had proudly proclatiment its ability to "know all things." Mr have seen the seiences abandoned by sane philesophy and leit to be misinterpreted by Materialism. Now, at last, in the new Scholastieism we have a positive philosophy that gives batk certainty and security to the sciences and offer's some positive "xplanation of the great Enigma. Nan camnot livo on negations: by recent systems of philosophy his soul has been starved and left desolate, and he is now hungering for positive truth. If he turns to the new scholasticism he is much more likely to find it than elsewhere:-

"There he will find a counteraction and, if I may say so, an antidote against contemporary Materialism. There, where science, hitherto interpreted by a group of materialists, seemed to furnish negative solutions, the same science on the same problems now furnishes positive results at Lomvin. What will be the outcome of this system in twenty-fifty years? At the decline of our critical age, do we not see breaking, in this direction, a new dawn-that of an organic age, and of an affirmative plitosophy? If the slow moral ancesthesia produced by the influential scepticism of the sacant has long been a source of uneasiness to every serious mind, will not the certainty now restored by science and jealously guaranteed by it, be to the same serious mind a source of strength and comfort? People had almost begun to despair of knowledge. "Science is sad," said Renan; and in that little phrase lay hidden and cowering all that 
ironical pessimism with which he has, as it were, drugged us. But I expect the opposite effect will be wrought in the long run by metaphysical certainty through science. After a series of reactions, at the end of an important cycle of discoveries and demonstrations, let us hope that men will awake from universal scepticism to find in science a source of joy and peace. Yes, that is the aim of philosophy : to hasten that hour of light for men, to bring it nearer to them. They pine away on empty formulæ so long as certainty appears not in its true form, which is science. We must then force it to appear, and lead back souls to themselves and to God by this sweet violence, as if nothing should be one day more evident than what we shall no longer merely believe but know, - that we have souls acknowledging God no longer merely because $\mathrm{He}$ has said that $\mathrm{He}$ is, but because we know it and have proved it." 1

The beneficial results which indirectly redound to Catholicism, especially in Belgium, from this growing prestige of the new Scholasticism, would be hard to overrate. Nowadays, more than ever since the early centuries of Christianity, Religion is attacked by false philosophies, and relies on true Philosophy for her defence. The same is true of Morality and social order in general. And true Philosophy is not any system specially manufactured for polemical ends : it is the Philosophy which is a rational interpretation of the sum total of things :-

To the solid ground

Of Nature trusts the mind which builds for aye.

With such a Philosophy the minds of the young Belgian Catholics are formed at Louvain. It is a living and progressive and inspiring discipline. It anchors their minds in Truth in this age of doubt and shifting unbelief. It remains with them in

${ }^{1}$ Deux Centres, etc., p. 6r. 
after life as an illuminating intellectual heritage, and as a vitalizing force that stimulates to noble action. It fills them with an enthusiasm for the "things of the mind." It puts the highest ideals in religious and social, and civil action, before all in common; and ensures community of interests and activities. It is not surprising, therefore, to find the new Scholasticism making so many proselytes, to find so many young Catholics issue from the University of Louvain. and from the halls of its Philosophical Institute to attain positions of the highest eminence in the parliament, in the courts, in the government, in the schools and universities of the State. With such men as these to leaven society the future of Belgium is full of bright hopes.

What are the causes of this widespread and beneficial influence exerted by the new Scholasticism? How are we to account for the rapid progress it has made and the happy results it has already achieved ? Chiefly by the spirit that animates the new movement, and which we have been trying to outline in these few pages. The whole movement is a triumph of the Truth, - an illustration of the proverb : Magna est Veritas et pravalebit. Nor should Catholics wonder at that. They know that they possess the Truth in inheriting a philosophy that is in such wonderful harmony with the conclusions of Science, with the demands of Reason, and with the dogmas of Faith. Should we not rather wonder that such an instrument had not been hitherto more powerful in their hands? It was because they did not use it aright. And herein lies the second and equally important reason of the striking success of the Louvain School. They are zealous in the propagation of the Truth. They do not hide their light under a bushel. They come forth fearlessly into the twentieth century with their combined treasures of medieval 
wisdom and modern science. From those treasures they bring forth the nova et vetera. They dispense those intellectual riches to their students and to a wider public in the garb of the living vernacular-and their books are being translated into most of the European languages. They spare no pains in preparing and communicating the most solid doctrine in the most attractive form. Their teaching is a living, organic, vitalizing formation, not in any sense a dry, unreal, academic discipline.

"The work of Mercier offers itself as a vigorous reaction of the scientific spirit against a rigid and anti-scientific formalism.

"In opposition to the old procedure in Metaphysics which was unilateral, that is to say, bore exclusively on the data of the understanding, we are here in presence of a bilateral procedure, that is to say, one bearing simultaneously on the phenomena of nature and on the phenomena of mind. And each professor, on each question, is expected to observe and to respect this distinction, being officially appointed to show his students the same fact under its two aspects : the experimental and the rational. "1

\section{IV.-ORGANIZATION OF COURSES AT THE INSTITUTE.}

The Philosophical Institute is called indifferently the Institut Supérieur de Philosophie and Ecole St. Thomas d'Aquin. It is a special school or depart. ment of teaching within the Faculty of Philosophy and Letters. But it is autonomous within its own sphere; has its own president and professors, its own programme of studies, its own courses and examinations, and confers its own degrees. In this it is like the many other special schools that have sprung up and developed within the other Faculties

\footnotetext{
${ }^{1}$ Deux Centres, etc., pp. 52, 60.
} 
of the University, and whose existence forms a striking feature of the organization and methods of teaching at Louvain. We may instance the Ecole des Sciences Politiques ct rociales and the Ecole des sciences Commerciales of comsulaires in the Faculty of Law, and the Institut Agronomique in the Faculty of siciences. The professors of these various schools belong mainly but not exclusively to the corresponding Faculties: hence the professors of the various Faculties lecture freoly outside their own Faculties as well as within the latter.

Althomgh the Philosephical Institute had small beginnings its progress in every respect has been steady since its foundation. Whe have heard people cbject to its claim to the title of "higher" or "superior," on the ground that it begins at the beginning, presupposes not even an elementary knowledge of philosophy, and adapts its teaching to the body of its students who are mainly youths commencing philosophy for the first time. But even granting all this we believe that it is nevertheless perecetly justified in its title. This we hope to make sufficiently evident in the course of these parges. Meantime it must be horne in mind that if the students of the Institute are maimly beginners in philosophy, these consist of a small number of the most talented students selected by competition from the six Belgian diocesan seminaries, and sent to the Louvain Institute for a special training in philosophy. Then, besides these native ecclesiasties, a small number of lay students also-chiefly from the Faculties of Law and of Philosophy and Lettersattend the courses of the Institute with the object of getting a special grounding in that philosophy which is at the basis of all true religion, of all sound ethics, of all social and economic progress, and of all

'From 1900 to 1903 the numbers of its students each year were 46, 50, 67 , and 7, , respectively. 
individual, domestic and social rights and duties. Moreover, a goodly number of the students at the Institute, from the beginning, have been foreign ecclesiastics-many of them priests already versed in philosophy-sent there from all parts both to pursue their studies as far as opportunities allowed, and to familiarize themselves with all that is characteristic not only of the contents, but of the methods of the new scholastic teaching. Not only the continental countries, France, Holland, Germany, Poland, Switzerland, Italy, Spain, but the English-speaking countries England, Ireland, Canada, the United States, have been sending and are still sending their present and future professors of scholastic philosophy to the University of Louvain: knowing that there they will find scholasticism not merely in the classhalls as a discipline, but in living contact with modern science and in actual conflict with opposing systems in modern philosophic thought.

In 1905 there were about a dozen priests-secular and regular--from various countries, about the same number of foreign ecclesiastics, upwards of thirty Belgian ecclesiastics, and a small number of lay students, following the courses of the Institute. ${ }^{1}$ Very many of those who have already passed through its halls are now professors in their various countries, and a large percentage of its present students are intended for the same work.

A glance at the following programme ${ }^{2}$ will show how the three years' course is divided, and will help

Adjoining the Institute there is a residential College for ecclesiastical students in Philosophy - the Seminaive Leon XIII.-consisting of two separate buildings, one for priests and one for unordained students. There is a chapel attached. Every convenience is offered to ecclesiastics; and with its many obvinus advantdges for strangers, the terms are very moderate. The pension is 800 francs $(£ 32)$ for the academic year, payable in three parts; extras about $\ell^{2}$ additional. Opening with the modest number of seven students in 1892 , its inmates numbered fifty-eight a few years ago.

2 The programme given above is that for the academic year 1903-1904. It does not vary substantially from year to year. Cf. last year's programme in the Revue né-scolastique, pp. 339-340. 
us to realize the nature and extent of the teaching imparted :--

\section{First Year-Baccalaureate. \\ General Courses.}

Logic (D. Mercier, and M. De Wulf of the Faculty of Philosophy and Letter's), four classes of an hour and a half, or six hours per week, during first half-year.

Ontology (M. De Wulf), four classes, or six hours per week during second half-year.

History of Medireval Philosophy (II. De Wulf), two years' course, first part, one class per week during first half-year.

Physics (M. 'Thiéry of the Faculty of Medicine), four classes per week during first half-year.

Psychophysiology (II. 'Thiéry), three years' course, two classes per week during second half-year.

Chemistry (M. Nys of the Faculty of Sciences), three hours per week during first half-year.

\section{Special Courses.}

(FIRST SECTION.)

Trigonometry, Analytical Geometry, and Differential Calculus (M. Sibenaler of the Faculty of Sciences), two classes per week during whole year.

General Biology, Botany, and Zoology, with Practical Exercises (A. Meunier of the Faculty of Sciences), two classes per week during second half-year.

General Anatomy and Physiology (M. Ide of the Faculty of Medicine), two classes per week during second half-year.

\section{(SECOND SECTION.)}

Political Economy (M. Defourny, chargé de cours), two classes per week during first half-year.

Method of Historical Criticism (A. Cauchie of the Faculty of Philosophy and Letters), two classes per week during first half-year. 


\section{Second Year-Licentiate.}

General Courses.

Cosmology (M. Nys), three classes per week during first; four during second half-year.

Psychology (D. Mercier and M. Thiéry), two years' course ; two hours per week during whole year.

Psychophysiology (M. Thiéry), three years' course. See Baccalaureate.

Moral Philosophy (J. Forget of the Faculty of Theology), four classes (six hours) per week during whole year.

History of Medicoval Philosophy (M. De Wulf), two years' course, second part.

History of Ancient and of Modern Philosophy (M. De Wulf), two years' course, two classes per week during second half-year.

Anatomy and Physiology (M. Ide), two classes per week during first half-year.

Special Courses.

(FIRST SECTION.)

Integral Calculus (M. Sibenaler), two classes per week during first half-year.

Analytical Mechanics (E. L. J. Pasquier of Faculty of Sciences), two classes per week during first halfyear.

Embryology, Histology, and Physiology of the Nervous System (M. Ide), two hours per week during first half-year.

Mineralogy and Crystallography (F. Kaisin, of Faculty of Sciences), two classes per week, second half-year.

\section{(SECOND SECTION.)}

History of Social Theories (M. Defourny), two classes per week, second half-year.

Method of Historical Criticism (A. Cauchie), two classes per week, first half-year. 


\section{Third Year-Doctorate.}

Psychology (I). Mercier and A. Thiéry), sce Licentiate. Psychophysiology (II. Thiéry). see Baccalaureate. Natural and Social Lare (S. Deploige of the Faculty of Law), four classes (six hour's) per week during first half-vear.

Theodicy (D. Mercier). one class per week during year.

Theodicy (L. Becker of the Faculti of Theology), two classes per week during vear.

History of Ancient and of Modem Lhilosophy (M. De Wulf), see Licentiate.

Apart from the Practical Courses and Laboratory work, of which we shatl speak later on, the above programme represents in faithful outline the amount of work done by professors and students alike. Each student standing for degrees gets a detailed oral eximination in each subject from the professor of that subject. In addition. written and original dissertations on philosophical theses are required both for the Licentiate and for the Doctorate. Students who have got their Doctorate with the highest distinction may return afterwards to the Institute to pursue their studies. to write and publish a book on some philosophical question, and to sustain a public defence of a number of philosophical theses. In this way they qualify for the further degree of Docteur agrege of the school of St. Thomas: the agrégation corresponding more or less to Junior Fellowship in the Royal University of Ireland.

As will be seen from the programme. the teaching is extended over three rears. and during the first two the courses are divided into general and special. The general courses are obligatory on all. They comprise all philosophy proper including the history of philosophy, and, in addition, the natural sciences in direct connection with philosophy: physics, chemistry, anatomy, physiology and psychophysiology. 
The matter of all the general courses of the three years, without exception, must be presented at the examination for the Doctorate. The special courses fall into two sections of very different kinds: the first comprising mathematics and the natural sciences, the second comprising economic, social and political sciences. Those special courses are described as optional, but they are optional only in this sense that the student may choose either the first or the second section according to his taste, but must choose either section. If he choose the first section he has yet further choice between mathematics and the other courses of that section.

One cannot help being struck by the close alliance thus secured between the sciences and philosophy. Cosmology - the philosophy of matter-can be studied, as it ought to be, in connection with chemistry, physics, mineralogy, mathematics, etc. Psychology - the philosophy of life-in connection with biology, anatomy, physiology and psychophysiology. Ethics - the philosophy of conduct-in connection with the social and economic sciences. And this union is not merely apparent but real. It is not a mere juxtaposition but a living, actual intercourse between philosophy and the sciences. This will be better appreciated when it is understood that chemistry and cosmology are taught by one and the same professor who is specially qualified in each, and that psychophysiology and psychology are likewise taught by one and the same professor similarly qualified. The former, Canon Nys, is Doctor in Sciences as well as in Philosophy, having studied chemistry under Professor Ostwald in Leipsig; the latter is Doctor in Medicine as well as in Philosophy, and studied psychophysiology under Professor Wundt at the same university. It is hoped that the same principle will be gradually extended as far as may be feasible to the other departments also. 
Another feature of the teaching of the Institute is that it is in French throughout. Occasional debating exercises are held in Latin. The works of St. Thomas and some other Latin text-books are in the hands of the students. But that is all. Both the text-books and the teaching of the Institute are in the vernacular. In view of the prolonged controversies that have been carried on in the Continental Catholic reviews relative to this whole question of the advisability of teaching philosophy and even theology to ecclesiastical students in the vernacular, it was not to be expected that the innovation at Louvain would escape opposition. As a matter of fact Leo XIII was for a time so much influenced by the "Latinists" as to order the adoption of Latin in the philosophical courses there. But when it was represented to him that, as a consequence of this mandate, the Institute was rapidly losing its lay students, he at once withdrew it, and allowed the use of French to be continued. Speaking to the Belgian Catholics in December, 1900, he remarked that the studies of the Institute were intended for laics as well as for clerics. "And that," he added, "is why I have decided that while the philosophy of St. Thomas must be studied in Latin the courses there should be given in French." Mercier could soon afterwards point to the brilliant successes of some past students of the Institute, in their theological studies at the Gregorian University in Rome, as a proof that the study of philosophy in the vernacular does not necessarily handicap the student who has to study his theology in Latin.

$\mathrm{He}$ would have a very inadequate conception of the professor's duty who would see nothing further in it than the mere oral and passive transmission to his students of the legacy of learning bequeathed to him from the past; and he would have a no less imperfect conception of the student's duty, who 
would limit it to the mere passive reception and rehearsal of such an irksome load of " learned lumber." Personal, original, scientific work or research in some department, under the direction of his professor, ought to be expected from at least the student who aspires to honours. A fortiori, the professor himself is expected to undertake and carry on such work, to study and to write if he wishes successfully to teach. To give him a fair opportunity for doing so, care is taken that he be neither obliged to expend his energies over too wide a field nor unduly overburdened with class work. ${ }^{1} \quad$ A glance at the programme of the Institute will show how they are aiming at such a division of labour amongst the numerous members of an already large and efficient staff at Louvain. We find the teaching of philosophy proper divided amongst seven distinct professorsone of whom also teaches chemistry, and another physics and psychophysiology. We find a distinct professor for higher mathematics, a course that is frequented only by a small number of students; and we find four distinct courses in the biological sciences given by two additional professors. These will suffice as examples: a further perusal of the programme will reveal additional indications of the same tendency towards the most liberal staffing of the professorial body, with a view to securing still greater specialization of energy.

The results of this enlightened educational policy in Louvain have been of the happiest. There is no rush or hurry over long programmes in short periods, none of that superficial scampering and cramming without any time to think. The work is well done. The professor can master thoroughly the special branch he has a taste for, has time to write about it if necessary, and to make it interesting to his students-

' It is difficult to strike an average where there is so much variety. We should say that about six or seven hours' class-work per week would represent the average at the Institute and University. 
whose work also, owing to their comparatively small numbers, he can often personally supervise. $\mathrm{He}$ discusses any points they submit to him. helps to clear up their difficulties, aids them with his advice and suggestions in preparing their dissertations, and by his own personal example of industry and devotion to his work sets them an example which. perhaps, proves more precious to them in after life than anything else he may have taught them.

A printed programme is often at misleading index to the quantity and quality and character of the work done at an educational establishment. It is not so in the present case : and perhaps we cam best show this if we supplement its meagre outline by a few comments based on personal experience.

V. TEATBOOKS AND TEACHING AT THE INSTITUTE.

The eourse of formal logic taught is that comprised in Mercier's Logique. which forms the first volume of the Cours de Philosophie that is being published by the co-operation of a number of the professors at the Institute. The seience heretofore known as Material Logic. or Logica C'ritica, is dealt with by Mercier in his well-known volume on Critériologie. Générale. This subject is still taught immediately after logic proper at the Institute, although Mercier claims that the proper place for it is immediately after psychology, with which it has undoubtedly an inseparable connection. He has accordingly made it the fourth volume of the Cours. his Ontologie forming the second. and his Psychologie the third volume.

There is no doubt about the difficulty of initiating beginners. who are as yet strangers to Psychology, into the various theories of truth and certainty. of

1 This is especially true of those students who frequent the fractical or Seminaire courses, or who undertake Laboratoy work in any departinent. 
scepticism and dogmatism, of idealism and realism, of the subjectivity or objectivity of human knowledge. It is perhaps even more difficult to deal with those questions in an intelligent way at that early stage than with any of the metaphysical abstractions of general ontology.

In the department of Criteriology the publication of Mercier's Critériologie Générale has undoubtedly marked an epoch in the study of questions concerning the Theory of Knowledge. Mercier had made a special study of Psychology and of the Theory of Knowledge, and the appearance of his book on General Criteriology, now in its fifth edition, excited widespread interest in Kantian as well as in Catholic circles. It was only natural that it should, for it was about the first serious and sustained attempt on the part of a representative of scholasticism to examine the numerous questions raised by the Critical Philosophy of Kant, from the point of view of that system, and independently of any of the scholastic presuppositions questioned or called into doubt by Kantism. The very first principles of scholastic philosophy had been rejected by Kantism, as indeed by most if not all modern philosophic systems. If these are to be met effectively by the scholastic he must cease to entrench himself behind such dogmatic principles, and come out to meet his adversaries upon their own ground. That is what Mercier has done in discussing the nature of truth, certitude, knowledge, etc. with the champions of scepticism on the one hand and of exaggerated dogmatism on the other; with French traditionalists on the one side and with the psychological subjectivism of Scotch and German schools, and especially of Kant's Critique of Practical Reason, on the other. $\mathrm{He}$ vindicates the necessary character of ideal judgments against the positivism of Taine and Mill and Spencer. But it is especially for its searching and 
vigorous analysis of the Transcendental Criticism of Kant's C'ritique of Pure Reason that Mercier's book is most noted. He maintains against Kant the objective character of the mental act of judgment, and the reality or extra-mental validity of the universal concept. At first his point of view seemed to have been misunderstood by various Catholic philosophers, and perhaps the most enjoyable pages of his thoroughly interesting volume are those devoted to answering the various critics of his definition of truth, and of his teaching as regards the problem of the validity of human knowledge.

Far more significant, however, are the criticisms and controversies to which his attack on Kantism gave rise in the Kantian schools of Germany. A professor in Halle took up Mercier's book as a basis for a pricatissimum course with his students. Another professor of the same university devoted an article to it in the Kantstudien. ${ }^{1}$ in which he pronounced it quite a remarkable production that must be taken aceount of by all Kantists. The concluding words of the article show that Kantists at least regarded the work as something quite different from the ordinary handling of Kant by the scholastics:-

"The Kantist is quite accustomed to see the Critical Philosophy insulted over and over again in Thomist works. . . . Tery rarely does he meet with a serious discussion of its problems. But here we have a book which carries on throughout a searching and really scientific discussion of Kantism. A book of this kind is useful, even to the reader who cannot adopt the solutions proposed, for he will be likely to find in it some light thrown on the problems that are engaging his attention."

These are only a few of the many notices taken of Mercier's work in Germany. Needless to say, his critics are no less divided as to the justice or

${ }^{1}$ Vol. i., I901. 
injustice of his appreciation of Kant's Philosophy than they are in interpreting the Kantian system themselves.

The domain of Ontology is, of its very nature, abstruse and uninviting to the beginner; yet even here the clearness of exposition and wealth of illustration so characteristic of the books of the Institute, succeed very largely in making even these nebulous regions attractive to the young explorer. There is a very pleasing contrast between these books and the dry, didactic and dogmatic conciseness of the ordinary text-book on Metaphysics. And it is not that Mercier's Ontologie shirks any of the numerous and profound difficulties with which ontology is so abundantly strewn. On the contrary, he faces them boldly and discusses them candidly; he adopts the views that recommend themselves to him on their merits ; and even when he fails to bring us with him he never fails to make us think deeply and seriously and understand the questions better-even though we may not be able to settle them to our own satisfaction. For example, his remarkable view, that in the analytical order an adequate ultimate foundation for possibles and their properties is to be had in the abstract concepts derived from actual experience, and that, accordingly, the Augustinian argument for the existence of God, the Infinite Exemplar, based on the properties of possible essences, the "incommutabilia vera," is a worthless argumentthat view is controverted by very able philosophers. Although we believe that the issue here involved is one of the most fundamental in philosophy, we can at present do no more than note the fact that such a difference of opinion prevails. Throughout the whole volume Mercier is an earnest supporter of Thomistic views regarding the relations of essence to existence, of nature to personality, of the individual to the universal, and of substance to accidents 
Particularly worthy of study are the sections on the existence of substances, on final causes, on the order of nature, on the beautiful, on esthetics and notions of art. The study of quantity, space and time are very properly left to their rightful places in cosmology" and the study of "being, finite and infinite" to theodoer.

The History of Philosophy at the Institute is in the hands of one of the best authorities at the present day on the heretofore much neglected Mledieval Period. Professor De Wull's Histoire de la Philosophic Wédiérale ${ }^{1}$ is unquestionably the best book of its kind on the subject. It brings together and utilizes in a masterly way the results of the allimportant researches of Ehrle. Denifle, Chatelain, Baemuker, Picavet, Rubezinscky, Clerval, Vaeant, Mandonnet, ete. within the past twenty years in the domain of the Vlidelle Age philosophy: and it is no exaggeration to day that these researches have brought about some revolutions in traditional views about the scholastic and anti-seholastic systems of the Niddle Ages. The companion volume published by him under the title of Introduction it la Philosophie Néo-ścolastique gives a luminous presentation of what Scholastic Philosophy really was and is and is likely to be, of its genesis, growth and development in the Viddle Ages, of its relations to catholic theology, to the sciences, and to opposing philosophic systems, of its method and contents, of the causes of its decay and the conditions of its successful revival.

Scholasticism thus placed in its proper historical setting has simply a new meaning and a real attraction for the student. The studies of Professor De Wulf have certainly thrown around it for his students an interest it could not otherwise possess. While the medieval period naturally receives most attention,

\footnotetext{
1 1900, in Sro., viii. + 4 So pp.: 2nd edition, 1905, vi. +i56s pp. In English translation is in course of preparation.
} 
both ancient and modern systems get ample and adequate treatment as well.

Physics is a compulsory subject for the Baccalaureate at the Institute. "It is studied there mainly from the theoretic or speculative point of view, as leading up to philosophical theories. Though it is an elementary course - treating of the properties of matter, heat, light, sound, magnetism and electricity, in one term with four classes per week-it is a sufficient if necessary preparation for the study of cosmology, and is insisted on as such.

A good elementary course of Chemistry is likewise insisted on at Louvain. Three classes per week for half a year are devoted to it. Specimens are shown and experiments made as far as possible. Special attention is paid to chemical theory and its relations to the scholastic theory of matter and form in cosmology. The field covered embraces organic as well as inorganic chemistry : it is supplemented by the elements of biological chemistry in the special courses of biology, anatemy and physiology.

The prominence given to the course of Cosmology at the Institute is significant of the close bond of union which exists between the philosophy of matter and the natural sciences in the neo-scholastic system. Cosmology appropriates three hours per week during the first term and five during the second. As taught at the Institute this course does not touch the questions of the origin and destiny - the efficient and the final causes-of the universe. It leaves these to natural theology and confines itself to a thorough investigation of the ultimate nature-the constitutive material and formal causes-together with the properties and activities, of the inorganic universe. The treatise written by Professor Nys on cosmologie -forming the seventh volume of the Cours de Philosophie-is a work of an exceptionally high standard of excellence. Out of 575 pages no less than 150 
are consecrated to a direct examination-the most searching and powerful we have ret seen-of the modern Atomic or Mechanical Philosophy of the Universe. He subjects its claims to the successive tests of all the physical sciences-especially of chemistry; and, with his full and intimate knowledge of the latter, he shows by irrefragable reasoning that whatever may be the ultimate philosophical explanation of the Universe, Atomism certainly is not. No idol was ever more thoroughly demolished than that of a "Cosmos built up by inert matter and kinetic energy" is in those masterly pages. To the scholastic conception of the nature and properties of the material universe: to the doctrine of the double constitutive principle, material and formal, of all corporeal being; to the essence formed by their union; to a full and exhaustive study of quantity, mass, volume, impenetrability, etc.: to the natural forces of material things: to the qualitative difference of these forces, and the current theory of their mutual convertibility; to motion, kinetic and potental energy; to the harmony of the scholastic conception with the established facts of the various natural sciences-to a full treatment of all those questions he devotes nearly 400 pages. The remaining 40 pages are given to an examination of the pure dynamic and the atomico-dynamic theories. This excellent text-book is supplemented by two additional monographs or special studies, the one on Space and the other on Time, from the pen of the same author. Both these abstruse subjects are dealt with in a very masterly and attractive manner. The various theories are marshalled and criticized, and the author's clear and incisive reasoning cannot fail to recommend the moderate realism embodied in his views.

Psychophysiology-called by many other names, amongst which "experimental psychology"-is a 
comparatively new science. It is simply the study of conscious states in their relations to their physiological and physical concomitants. Its method is objective and experimental (physiological), as well as subjective or introspective (psychological). It analyzes our ordinary complex conscious activities into ultimate constituent elements which it calls impressions. The study of those from the quantative and qualitative points of view forms the first part of the course. It next passes to the study of these same impressions combined and co-ordinated in time and space so as to form conscious representations. Finally, in a third part it examines the associations of these representations and the laws that govern such associations. It covers that exceedingly wide and unexplored borderland between physiology and psychology, and seeks by inductive methods to arrive at the discovery of natural laws in that domain. For some time this new science was looked upon with some suspicion by catholic philosophers-partly because they feared that it rested upon materialist presuppositions, and partly because its own early advocates were unduly enthusiastic about its significance and too sanguine in making promises which it could never hope to fulfil. It is now more justly appreciated by both parties, and is recognised by all as a useful auxiliary to psychology proper, and a department of research that may bring to light valuable information about the nature and conditions of conscious organic activities. As a distinct science with a definite field of investigation it has had its origin in Germany-its first great exponent being Professor Wundt of Leipsig-and it has been followed up with the greatest attention in many of the NorthAmerican Universities. ${ }^{1} \quad$ Professor Thiéry, who

${ }^{1}$ See Mercier's Origines de la Psychologie Contemporaine, pp. $2{ }_{4}$ seq., and Appendix B. There are many recent works in English on Physiological Psychology, and Professor Wundt's classical work is being translated into English. 
gives this course at the Institute, studied under Wundt at Leipsig, and is the author of an important. and original monograph on the sense of vision: Optische Geometrische Täuschungen.

Passing next to the teaching of Psychology proper, we find very ample provision made for two distinct courses of a year each. They are given alternately and are frequented both by the students for Licentiate and by those for Doctorate. The first is a general course on the nature of living things and the principle of life-Psychologie Naturelle. It follows closely the text of St. 'Thomas' Commentary on Aristotle's treatise De Anima. 'The Latin text has been specially edited at the Institute, and a free, modernised exposition and interpretation of the text in French, has been also published by Professor Thiéry under the above title-Psychologie Naturelle. The second course of Psychology is a rery full and exhaustive study of the whole subject based upon Mercier's well-known work, La Psychologie, which forms the third volume of the Cours de Philosophie.

Mercier's Psychologie is unquestionably one of the ablest and most remarkable books that has been published on this subject from the scholastic point of view in recent years. The appearance of its first edition in $\mathbf{1 8 9 2}$ attracted considerable attention, and was called, not without reason, "an event in the teaching of scholastic philosophy." It has now reached its sixth edition in two octavo volumes of nearly 400 pages each, with four excellent lithograph plates in the first volume. This volume is devoted to vegetative and animal life, and contains the most copious and up-to-date information on the anatomy and physiology, as well as the psychology proper, of living organisms, both vegetative and sentient. The second volume deals with the higher activities of man, his nature, origin and destiny. The whole is a masterly production, and clearly shows 
the substantial harmony of the traditional scholastic psychology with the results of modern research.

The importance attached to the study of the biological sciences, subsidiary to psychology, calls next for a brief word of comment. A philosophical knowledge of psychology is simply impossible without at least a general acquaintance with the group of natural sciences that deal with living organisms. Hence a general course in anatomy and physiology is regarded as the minimum required for all. Three hours per week during a whole term are thus devoted to studying the structure and functions of the various animal tissues, organs, members and systems-skin, bone, blood, circulation, respiration, digestion, internal organs, muscle, nervous system, brain, external senses, sensation, spontaneous and reflex movements, emotions, passions, nervous diseases. It is rightly contended that the student who approaches psychology without the knowledge of those things as a groundwork, and who studies it out of a medieval Latin text-book whose terminology and illustrations are based on the schoolmen's-or Aristotle's-notions and theories of physics and physiology, is practically wasting precious time trying to comprehend, as the elements of a real and actual psychological synthesis, much that is unreal and without value except to the student of history. If the greatest of the scholastics-St. Thomas of Aquin-were teaching philosophy at the present day, he would introduce his students to psychology through contemporary -not medieval-physiology, thereby merely showing himself as enlightened and progressive in the twentieth century as he actually showed himself amongst his contemporaries in the thirteenth. At Louvain they think they are loyal to the Angelic Doctor's spirit, and they are not deceived. . . . Besides the minimum contained in the compulsory course just referred to, they give their students ample 
opportunities in three distinct special courses to pursue further this same line of studies. In a special course of anatomy and physiology the professor of the general course goes more deeply into the histology or microscopic structure and functions, as well as into the composition, physical and chemical, of the various organic tissues. In a second and still more important specia! course on the embryology, histology, and physiology of the nerrous system he follows step by step, from the fertilization of the oxum to the full maturity of middle life, the gradual growth and development of the nervous system which is the immediate organic basis of consciousness, and which is therefore of such prime importance to the psychologist. I thired special course on general biology is devoted to an elaborate study of the basis of all organic life-that marvellously complex unit, the living cell. Its structure, its chemical composition, its functions, its manner of division, its differentiation in plant and animal, its most striking characteristics in the two domains of botany and zoology-such are the main headings of the programme covered by this course. With such admirable opportunities as those there is absolutely nothing to prevent a student whose tastes lie in the direction of psychology from equipping himself thoroughly for a complete mastery of his subject.

Students whose tastes lie rather in the direction of the moral and social sciences can choose the second section of optional courses during their first two years at the Institute. They will thus enjoy, firstly, a series of lectures on the method of historical criticism from Professor Cauchie, a distinguished editor of the Revue d'Histoire Ecclesiastique; and, secondly, a course on political economy and another on the history of social theories, both given by Professor Defourny, the author of a valuable study entitled La Sociologie Postiviste: Auguste Comte. The 
course on political economy, though elementary, is extremely useful and instructive and much appreciated. It gives a clear grasp of the principles of economics, and deals especially with their application to the actual conditions of Belgium. In a word, it gives the student a fund of knowledge about social and economic principles and problems which will enable him to understand and to deal effectively with those problems when he goes amongst the people afterwards, whether as priest or layman.

The course of Ethics at the Institute extends over two years. During the first year three hours per week are devoted to moral philosophy; during the second, six hours per week of the first term are devoted (by Professor Deploige, now President of the Institute in the place of Cardinal Mercier) to natural and social law. Mgr. Deploige is the author of a study on St. Thomas and the Jewish Question, and of an original work of considerable value on the Referendum in Switzerland. The latter bas been translated into English in the Studies in Economics and Political Science (London School of Economics and Political Science).

There are, likewise, two distinct courses of Natural Thsology during the student's third year at the Institute. One class per week during the year is devoted to a full and complete examination of all philosophical systems, directly or indirectly atheistical, and to the establishment of the existence of God. A second course of three hours per week during the year is devoted to the nature, attributes, knowledge, providence, etc. of the Deity.

We have now completed our general analysis of the class work proper. This represents the theoretic side of the Louvain training: though many of the lectures in the scientific department are largely interspersed with experiments and concrete illustrations of various kinds. But there is, in addition 
to the class-hall teaching proper, a distinct supplementary department of what are called Cours Pratiques, namely:-

Laboratory work in psychophysiology under the direction of Professors Thiéry and Michotte-a few hours per week for one term each year.

Laboratory work in chemistry, under the direction of Professor $\mathrm{Ny}_{\mathrm{s}}$ - a few hours per week for one term each year.

Social philosophy conference, under the direction of Professors Deploige and Defourny-once a week during the year.

Seminary of the history of medieval philosophy, under the direction of Professor De Wulf-once a week during the year.

Seminary of psychology, under the direction of Professor Noêl.

Professor 'Thiéry's laboratory was one of the first of its kind established outside Germany. It is well equipped with all the necessary instruments and appliances for psychophysiological research, and a number of students are initiated every year into the methods of investigating and experimenting in this domain. In the chemical laboratory a number of students are trained each year in the elementary practical work of chemical tests and analyses. In addition to these laboratories, the biological classhall is furnished with a large number of models and specimens to illustrate the various courses. Microscopes are provided, and preparations made and examined by the students under the direction of the various lecturers.

The seminaries of social science and of bistory are worked with a view to training a small number of students, who evince special tastes for those studies, in the methods of original research and original work in those departments. The students combine their 
efforts in a certain line of study under the guidance of the director of the seminary, and while they often thus render valuable assistance to him they are being admirably trained themselves to follow up the same sort of work. It is by means of this Seminar system-carried to such a high degree of perfection in the German universities-that the individual student, under the personal guidance of his professor, gets that specialized training which enables him to do sound and useful original work in his chosen branch afterwards.

Besides this official teaching, theoretical and practical, the students of the Institute have two distinct voluntary societies, each with its weekly meeting, under the direction of two of the professors. At these meetings papers are read and discussions carried on by the students themselves and by strangers. The subjects-usually philosophical questions of present-day interest-are invariably dealt with in an attractive and pleasing manner. The meetings are very instructive and have an educational value that it would be difficult to exaggerate.

VI.-PHILOSOPHICAL LITERATURE AT THE INSTITUTE.

What contributes, perhaps, most largely to the success of those bi-weekly reunions is the existence of a splendidly-furnished philosophical reading-room at the Institute. The Salle des Periodiques deserves more than a passing mention, for it is a prominent feature of the Louvain philosophical training. The teaching of neo-scholastic philosophy purports to bring the student face to face with all the philosophical systems of the present day as well as with modernized scholasticism. And so it does. In this reading-room the student finds himself in presence of about one hundred and fifty of the leading philosophical 
reviews of the world, of every shade of opinion from all parts, and in many languages. The students have free access to them, are sometimes referred to current articles on the topics discussed in class, often make use of them for their philosophical societies, and oftener still in preparing their yearly dissertations for degrees. When we reflect on the important part played nowadays by the periodical in the advancement of learning we can appreciate the immense educational value of such a readingroom.

Since the year 1895, they have been forming in this same department a very full philosophical bibliography-both according to authors and to subjects-by means of which a person can find out at once all the philosophical literature that has appeared on any subject during those years. The idea is, if we mistake not, to form at the Institute a sort of international Bibliographical Bureau for the use of students and professors of philosophy over the world. The system of cataloguing adopted is the decimal system of Dewey, in use at the Brussels International Office of Bibliography. A "Sommaire Ideologique " of works and reviews on philosophy is published quarterly as a supplement to the Revue Néo-Scolastique - which thus puts its subscribers in possession of a continuous and up-to-date bibliography.

The Revue Néo-Scolastique is the principal periodical published by the Institute, and is recognised as one of the leading philosophical reviews of the Continent. It was founded in 1894, and is conducted, under the direction of Mercier and the editorship of De Wulf with the co-operation of the professors and past students who form the Societé Philosophique de Louvain. It appears quarterly in numbers of about 200 pages, the subscription being ten francs per year for Belgium, twelve outside Belgium. Each number 
contains: (1) articles proper on philosophical subjects ; (2) Mélanges et Documents, shorter studies on current questions, reviews and movements; (3) a chronicle of events at the Institute; (4) reviews of books ; (5) the Sommaire Ideologique already referred to; (6) a supplement of forty or fifty pages called the Mouvement Sociologique, conducted by the Belgian Society of Sociology. The Revue Néo-Scolastique enjoys a wide circulation and is self-supporting. Practically all the reviews and periodicals that stock the reading-room of the Institute are received as exchanges for this review. The Revue Sociale Catholique, founded in 1896 by Professor Deploige, and M. Legrand of the Agricultural School of Gembloux, is devoted chiefly to labour legislation and to social and economic questions amongst the masses. The Revue Catholique de Droit, founded in 1898 by Professor Crahay, of Liège University - a past student of the Institute-is also concerned chiefly with the labouring classes. Both of those reviews are issued monthly from the Institute.

These various publications will convey some idea of the constant output of intellectual work which the foundation of the Philosophical Institute has been mainly instrumental in fostering and developing. Yet they really represent only a fraction of the total amount of published matter already to be found in the Bibliothèque de l'Institut superieur de Philosophie which has been in existence for the past few decades, and is growing in dimensions and importance every year. A few years ago the Institute set up a printing-press, and it now prints and publishes all its own literature. We have already mentioned the various volumes of the Cours de Philosophie that have been published up to the present. The fifth volume is intended by Mercier to deal with special questions, problems and theories regarding the validity of knowledge, under the title Criteriologie 
Spéciale. Volumes are promised on ethics and natural theology; and a compendium of the whole course in two octave volumes of about 500 pages each was published last year. ${ }^{1} \quad$ The various volumes of the larger courses are being translated into many languages. All have been done into Polish; all are being translated into Italian, Spanish and Portuguese. A German translation of Mercier's Psychologie has recently appeared, and English translations of Nys's Cosmologie, De Wulf's Histoire, Mercier's Logique, etc. are in preparation. Besides the periodical literature and the volumes of the Cours de Philosophie, we must mention two historical collections that are being edited under the direction of Professor De Wulf and M. Pelzer, entitled, Les Philosophes du Hoyen Age. It will comprise, firstly, a series of folio volumes containing the original texts of works hitherto unpublished or little known on medieval philosophy; and, secondly, a series of studies (in 8 vo volumes) on various medieval philosophers. The first volume of the first series contains the text of the famous treatise, De unitate formo, by Giles of Lessines, preceded by an introduction of 120 pages from the pen of Professor De Wulf. The four succeeding volumes - the first of which has already appeared-will contain the Quodlibeta of Godfrey of Fontaines. Volumes VI. and VII. (in the Press) will comprise the works of Siger of Brabant, edited by Professor Mandonnet, of the University of Fribourg, Switzerland. This is an excellent collection from every point of view, and no philosophical library should be without it.

The number of isolated pubiications that have helped to swell the dimensions of the Bibliothèque is very large, and some of them of great importance.

- Traité élémentaire de philosophie à l'usage des classes, édité par des Professeurs de l'Institut superieur de Philosophie de l'Université de Louvain ( 2 vols., $7 \mathrm{fr}$. net., Louvain, Institut superieur de Philosophie, I rue des Flamands, 1906). 
Glancing at the catalogue-which may be had on application at the Institute-we would fain bring many of them under the notice of our readers, but we must be content with mentioning two.

De Wulf's Histoire de la Philosophie Scolastique dans les Pays-Bas is a valuable work written for a prize offered by the Royal Academy of Belgium, and crowned by that body for exceptional merit.

Mercier's Origines de la Psychologie Contemporaine, published in 1898, "has contributed very much towards concentrating the attention of the educated world on what is going on at Louvain." German, English, French, Italian reviews of divers tendencies have greeted this work with words of praise. It is a masterly study-critical, historical and doctrinalon the rise and growth and various offshnots of Cartesian psychology, and on all the different forces and tendencies observable in the psychology of the present day. It is a work full of light and inspiration for the student of philosophy, and its concluding chapter on "Neo-Thomisme" strikes the keynote to that true scientific method which has won such well-merited repute for the Louvain pioneers of the new scholasticism.

A writer in the Critical Review, ${ }^{2}$ dealing with Mercier's Origines, pointed out to English readers that the new scholastic doctrines form the principal intellectual force actually at work in Belgium, and have a considerable influence in France, Germany, and Italy. He noted as "full of light and progress", those words of the author which are simply a summing up of the programme of the Institute :-

"We avail ourselves of Plato and Descartes and Leibnitz, of Kant and Fichte and Hegel and Wundt, just as fully, perhaps, and certainly just as sincerely as those who count us in the number of their opponents.

${ }^{1}$ Professor Dörholt, in the Theologische Revue, 1903, p. 292.

2 I 899, ix., I 7-I8. 
There is no Catholic philosopher who is not ready to sacrifice 'an idea many centuries old' the moment it manifestly contradicts an observed fact. For we also are accustomed to take observation as our starting-point, as the origin of all research, the source of truth, and the sovereign mistress of science."

And those words are an unmistakable echo of what we read in the Eterni Patris of Leo XIII : "libente gratoque animo excipiendum esse quidquid utiliter fuerit a quopiam inventum atque excogitatum."

\section{VII.-CONCLUSION.}

And as to the influence of Louvain teaching, in philosophy as in other departments, upon religious and social and scientific progress throughout Belgium, it would be difficult to overestimate its extent and value. Louvain is to Catholic Belgium what the throbbing heart is to the whole body, sending out its rich warm currents of life blood to stimulate and nourish the entire system. If there are to be found amongst the Belgian Catholic clergy and laity numbers of the best and ablest Catholic writers who uphold and defend Catholic and Christian principles and who attack the Godless tenets of liberalism and socialism in the press and in the pulpit and on the platform, by pen and by voice, without a moment's abatement of zeal, it is to the progressive and militant spirit of thought and action communicated to them at Louvain that such activity is due. If Catholic Belgium has numbers of cultured scholars ready and willing to defend social order, and to point to the true and just solution of complex social problems, and that with all the influence and authority requisite to make their voices heard, Catholic Belgium may thank the training that its youth receives in the various Faculties of Louvain 
University. The progress of Belgium in science and industry and agriculture is too well known to need more than a mention : to the scientific achievements and prestige of Louvain this progress is largely due. And material progress has not been accompanied in Belgium, as it often has been elsewhere, by a decadence in religion or morality, or by inattention to the higher and ideal side, the mental and spiritual side of life. Belgium's progress is not abnormal or onesided but wholesome and normal and well-balanced: and this is due above all to the fact that in her philosophy she has rejected the outré spiritualism of Descartes-the system that vainly tries to suppress or ignore the material, and thereby allows the senses to run riot and usurp the place of reason-and has espoused the moderate realism of the schoolmen-the philosophy that holds the golden mean between the spiritual and the material, that lays down the true relations between faith, grace and religion, on the one hand, and reason, nature, and morals on the other, thus, as it were, fulfilling the words of a great teacher, to " render unto Cæsar the things that are Cæsar's, and to God the things that are God's." 



\section{N D E X ${ }^{1}$}

\section{A}

Abbey Schools, I9o.

Abelard, 20, 27, 63, 67, I80, 198 .

Absolute, the, 220, 222 .

Abstraction Theory, 82, I 3I, I 32, I $33,237,247$.

Accident ( $v$. Substance), IOO, IOI.

Achillinus, 4I.

Adelard of Bath, 25.

Adelman of Liège, 22.

Agnosticism, I I I, 286.

Agrégation, 294.

Alanus of Lille, 20, 4O, I24, I42, I 88,260 .

Albert the Great, 20, 76, 77, 87, IO2, IO5, $20 \mathrm{I}$.

Albigenses, 30, 40, I88.

Alchemy, I 23, 200.

Alcuin, 29, 79, 80.

Alexander of Hales, 20, I05, I 24.

Alfarabi, 57.

Alkendi, 43.

Analytico-Synthetic Method, 2I, I 44, 205, 272.

Anatomy and Physiology, 307, 308.

Ancilla Theologice, 54, 61, 274.

Andronicus of Rhodes, 77 .

Angels, Scholastic Teaching on, I03.

Anslem, 20, 25 ; first scholastic, 46,64 .

Anti-scholasticism, meàning, 5 I, 68.

Aphrodisias, Alexander of, 77 .

Apologetics, 72, 198.

Appetite, I $36 \mathrm{seq}$.

Arabian Philosophy, I I I, I 29, I 33.

Aristotle, 24, 26, 78, 80, 81, I08, II 8 , 20 ; and Immortality, I 26 ; I 28, I 35, I40, I 75, 2 I9, $233,238,256,260,283$.

Aristotelianism, 8, 205, 21 8, 23I, $242,246,278$.

Arnauld, I 34, I 47 .

Arnold of Bonneval, 66.

Artist's Ideal, 243.
Arts, Seven Liberal, 23; and philosophy, 79, I68; Paris Faculty of, $8 \mathrm{I}$.

Asiatic Philosophy, 43.

Association, Need of, 209, 273.

Associationism, English, 23I.

Astral Souls, I2I.

Astrology, I 23, 200.

Astronomy, 87, I I9; Discoveries in, 148, 200, 225.

Atomism, 77, 165, 208, 213, 226, $227,304$.

Augustine, I 3, 74, 78, I I 2, I25. I 27, I 32, I6I, I 88, I98, 260.

Augustinism, 78, IOI, I06, I I 4, I 87.

Authority, Argument from, 78 , 260 .

Anthority, Moral, I40.

Autonomy of Scholasticism, I9 I, 274.

Averroïs, 30, 77, I88.

Averroism, and Scholasticism, 40, $4 \mathrm{I}$; in Italy, $47 ; 65,74$, I 26 .

Avicebron, IO2, I88, 224.

Avicenna, 30, 7 1, 82, 106 .

\section{B}

Bacon, Francis, 4, I 52, I 72 .

Bacoll, Roger, 50, 86, $20 \mathrm{I}$.

Bacteriology, 200.

Baeumker, 6, 8, I86, 279, 302.

Bain, 239.

Baldwin's Dictionary, on Scholasticism, 35 .

Balmes, I94, 236.

Barrès, I95.

Baumgarten, 239.

Baumgartner, 6, 20, 29, I 24, I 35 .

Baunard, 205.

Bautain, I93.

Belgium's Debt to Louvain Teaching, 316,317 .

Berenger of Tours, 22.

Bergson, I6, 195.

Berkeley, 232.

Bernard of Tours, $5 \mathrm{I}$.

1 The numbers indicate the pages. 
Bernard (St.), 66.

IBessarion, $4 \mathrm{I}$.

Besse, 185, I87, 207, 210, 266, $276,280$.

Biblical Criticism, I9o, I9s.

Biblingraphical Bureau, Louvain, $3 \mathrm{I} 2$.

Bibliothèque de l'Institut, Louvain, $3 \mathrm{I}_{3}, 3 \mathrm{I}+$.

Billia, I93.

Biography, 25I.

Biology, 200, 208, 230, 23I, 27I, 307.

Blanc, $51,55,57,60,73,74,143$. Blondel, icon.

Bontius, 20, 30, $9 \mathrm{I}$.

Bonaventure (St.), 20, 69, 97, 10I, I(1), IOR, I IS, I 38, I 59 .

(1)e) Bonald, I93, 236.

Bowerich, 230.

Pondinhon, 32 .

Boutroux, If, ISI, I $89,205,209$, 26) I, $28 \mathrm{I}$.

Bovillus, $4 \mathrm{I}$.

Brants, 25\%.

Brochard, 2si.

Brucker, 4. 5, 75, 152 .

Bulliot, 75 .

Byzantine Philosophy, +2 .

Cabal, 7 r.

Cantu, 3\%.

Capitular Schools, 22.

Carbonelle, 230.

Caro, $\mathrm{I}+3$.

Carra de Vanx, 57, 7 I.

Cartesianism, 32, 106, I 85, 230, $233,246,279,28 \mathrm{I}$.

Categories, I +1 .

Cathari, 30, 40, I88.

Catholic Philosophy, I93, I9.4, I97, 198, 274.

Catholics and science, 268 seq., 276

Cauchie, 292, 308.

Causality, Caluse, I Io.

Certitude, Problem of, 2 I 6, 235 , seq.

Character, Formation of, 249.

Charlemagne, I 3 .

Chatelain, 59, 302.

Chemistry, 1 $70,200,208,225,303$.

Child-Psychology, $25 \mathrm{I}$.

Cicero, i -8 .

Circular Motion Perfect, I 20, 149.

Claritas Pulchri, $2+2$.

Clerval, I 3, 279, 302.

Clifford Allbutt, 92.
Coimbra, 47.

Comets, I 19.

Commentary, 24, 77, 168.

Commer, roz.

Comparative Psychology, 252 .

Compendium, of Louvain Series, $3 \mathrm{It}$.

Comte, of), 219, 220, 222, 308.

Concept, ItI, 300 .

Concursus li, i I 5, I I 7 .

Conscience, Moral, I 39.

Constantine the Great, Is.

Constructive Methods, I9, I 7 . 258 .

(oprernicus, I.tS.

cornoleli, Ir. 275 .

cosmology, 2I ; Modern, 225, 27 I. $205, \quad 303$.

Cours l'rutiques at Louvain, 3 I ().

(ousin, 6, 53, 95, I43, IS2, I I.4, $230,23 \%$.

Crabay, l'rof., 313.

(reattion, IIt; of Soul, I 27 .

(remonini, $15 \%$.

(rituriology, 235 sey., 200 seq.

('vitical blhilosifihy, 215, 2 I6, 254.

(vitique (Kantiın), 2I6, 236, 300.

Crystallography, 200, 208, 225.

(1) (ure), 15\%.

\section{D}

1)'Ailly, Peter, It7.

1) Nlembert, 4 .

l)arwin, 233.

l)avicl of linant, 40, 96, 224.

1)avid the Armenian, 43 .

Di. Inima, 30 s.

Definitions of Scholasticism, $10-12$, I +2 .

I) floratio of Boolss, 29.

Defourney, Prof., 292, 308, 3 IO.

Delacroix, 6, 52, 68.

Demonstration, Scientific, I.fo, If I.

Denifle, 6, 59, 63, I 86, 279, 302 .

Deploige, Prof., 293, 309.

Descartes, 6, 20, 74, 82, I.49, I 72 , I $80,194,198,228,230,232$, $235,280,315,317$.

Deussen, I52, 162, 224.

Deutsch, 66.

Dewey, $35,54,3$ I 2 .

Dialectic Method, $62,6_{3}, 6_{4}$.

Dirlactics, 246, 258 .

Diderot, on Scholasticism, 34 .

Didiot, 204.

Diègo-Joseph, Fr., 194.

Diogenes of Laertius, I 3 . 
Discours de la Methode, 6.

Discoveries, Scientific, 148 ; and Schclasticism, I49.

Dissertation, I 70 .

Distinction, of Soul and Faculties, I 27 .

Distinction, of Substance and Accidents, IOI.

I)ivorce of Science from P'lilosophy, I $5 \mathrm{I}$.

l)oerholt, Prof., 355.

1)ering, 23I, 261.

Dogma, and Scholasticism, $5,3,190$.

Dogmatism, of new sicloolasticism, 260.

Domet de Vorges, Comte, I 72, I 79, I 86, $22 \mathrm{I}$.

Draina, 195.

Ducange, I 3 .

Duhem, 227, 228 .

Duns Scotus, 4, 10, 20, 25, 76, 97 , IOI, $105,108,113$, I 26, I 3 I, I $32,134,135,136,138$, 198 .

Durand de Gros, 220.

Dutens, I6I.

Dynamism, I 43, 21 3, 226.

Eckhart, I 7 I.

Education, 248, 250.

Eductio Formarum, etc., I 17.

Egypt, Priests of, I 58.

Ehrhard, 165.

Ehrle, 6, I 25, I86, 279, 302.

Elements, terrestrial, 12 I; celestial, 12 I opposite qualities of, 122.

Eleusis, I 88 .

Embryology, 230, 27 I, 308.

Encyclical Rterni Patris, I66, $204,265,316$.

Endres, 27.

Epicureanism, 77.

Erdmann, 6, 37, 55, 129.

Eric of Auxerre, 52 .

Eriugena (John Scotus), 20; as scholastic, 35,42 ; pantheism of, $40,51,52 ; 68,74,80,198$.

Errors in Scholasticism, 2 I I.

Espenberger, 66.

Essence and Existence, IOy.

Esthetics, 239, seq.

Ethics, 309, seq.

Etudes Franciscaines, 159, 194.

Eucken, 56, 164, 261.

Eudemonism, I 44.

Evolution in Philosophy, 162.

Evolutionism, Scholastic, I44, 252.

Exemplarism, 106, II 3.
Faculties (and Substance), IOI ; Division of, I 27.

Fallacies, Classification of, 258 .

Fathers of the Cliurch, I I2, I I 5 .

Fechner, 245.

Féret, 64, I 5 I.

Ferrère, 80 .

Fichte, 7I, I86, 216, 224, 3I5.

Finality, Final Causes, IIO, III, I 8 , 144.

Folk-Psycholony, 250, 251 .

Fonsegrive, I 85 .

Forcellini, I 3 .

Forget, Prof., 293.

Form, functions of, IO4; plurality of, 105; in man, 125 ; evolution of, I I 7 .

Forma Corporeitatis, 125.

Formalism, 147, I69.

Fouillée, oll Scholasticism, 34, 188.

Four Elements, I 2 I ; interchangeable, I22.

Four Temperaments, I23.

Four Internal Senses, I 29.

Franciscan School, I02, I03, 105, I IO.

Freedom of Will, I 36.

French in Louvain Institute, 296.

Freudenthal, 53, I6I.

Froschammer, $129,164$.

Fulbert of Chartres, 13, 22.

\section{$\mathbf{G}$}

Gaddi, Taddeo, $6 y$.

Galileo, I48, 150.

Gardeil, 64.

Garner of Rochefort, 40.

Gasquet, 245 .

Gassendi, 74, 198.

Geology, 225, 271.

Gerson, John, I 47.

Ghent, 227.

Gide, Ch., 256.

Gietl, 63.

Gilbert de la Porrée, 30.

Giles of Lessines, 25, 150, 314.

Giordano Bruno, .fI.

Glossner, I61.

God, Existence and Attributes of, I 12; Pure Act, I I2; A Priori Proof, 20 ; Knowability of, 195.

Godfrey of Fontaines, 10, 36, 76. 3 I 4 .

Gomperez, 157.

Gonzalez, 54, 76 .

Goosens, Cardinal, 265, 268. 
(iovernment, forms of, 1 fo.

(iratian, 3t).

Greek I'hilosophy, 1(17, 186, $21 \%$. 241 .

(iregorian Lniversity, 185,275 , 20 ( ).

Gillemard, I().

(junclisalvi, 20.

(iinther, 10:

(intberlet, its.

(intenbers, 1.j.

\section{H}

$11.11 \mathrm{~s}, 15 \%$.

Habit, $127,24 \%$.

Harlelin, I6.4.

llalle, 300 .

Hamilton, 220 .

llatzeld, 33.

IJaurcian, $6,1,1,15,37,38,8(9,8)$.

Heavenly bulles, sinperiority, (nicity of, I1), I 20 ; 1lotion of. 121; lnfluence of, 122, 123 ; fmmutability of 1.19.

Hegel, I6, g(1, 181, I82, 216, 220, $224,315$.

llemy of fillemt, 10, (x), (1)1, 70, $103,108,136,138,142$.

Iteptatemhon, 25.

Herbiut, 210, 235, 247.

llerrarl of Limblecre. 87.

llettinger, bof.

Hicrarch of Formo in Niltule, $11 \%$

Hiklegiatere 13.

1 limn, 230 .

Mistology, zis, ins.

llistory of Plufoupley, Medicial carelessmess about, 29, 183 ; Nodem attention to, 277,270 , ios; Modern exaggeration of, $182,184$.

Hogat11, 32, 172, 170, 19.4.

llugh of Amiens, $(x)$.

Hugh of st. Victor, $4,69,80,87$.

Iluet, 32 .

Huit, N. Ch., 204.

d'Hulst, I 66 .

IIumanism, I.f(), 17 I.

Hume, 210,238 .

Huxley, 2I0.

Hylemorphism, appled to Man, 124.

Hypothesis, 283.

lar, Jrof., 202.

Idées-forces (Fonillée), 188.

Immancuce, Philosophy of, I67, 223. lumortality of Soul, I26, Iy5.

Immutatio in senses, 131 .

Incommutabilia [ora, 187,301 .

Inlia, 2 I 3 .

Individual (and Universal), I07.

Individual Psychology, $25 \mathrm{I}$.

Individualism, I.4.4

Individuation, 10\%.

Inductive Methods, 87, 239, 257.

Innovations in Sicholatsicism, in 3 .

Inspiration of sicripture, 100.

Intelloctus lecns, 127, 133.

lutellect, (object of, 131; and Individual, 132 .

lodgoge, (x).

1sidore of Seville, 87 .

lves le Querilec, 185.

Janvier, stos.

Jasper, 111.

Jerome (st.), 13.

Jessen, 80.

Jewish Question, 309.

John of Salisbury, $22,40,42,70$.

Judgnent, I.t I, 300.

Justinian, 5, 6.

Kaisin, l'rof, 2y3.

Kant, 10, 71, 137, 162, 181, 184 , $19 t), 107,213,210,219,220$, $235,237,254,256,2(x), 315$.

Kantism, 95, 97, 162, 164, Ins, $222,238,242,253,300$.

liantstudicn, 107, joo.

Kanfmann, [o6.

Kepler, 148.

Kibn, 172.

Klentgen, 128, 175.

Knowledge in Scholanticism, 128 ; of the Immaterial, 111 ; 11tellectual and Sensible, $128,129$.

Kurth, 17,18 .

laboratory Work, 170, 29., 298, 3 I0.

I.a. Bruyere, 160 .

Iammenais, 236 .

I,anfranc, 64.

Lange, 97.

Langlois, on Dialectic Methoi, 36 .

Language of Scholasticism: its defects, 2.3 ; detinition of Scholasticism by, 3I-34; decay of, I 46, 147 ; recent controversies about, I 7 I-I 8 I, 296. 
Laspiasas, I43.

Latin, Scholastic, 23, I46, I 7 I.

"Latinists," I 72, i 80, 296.

Latty, I73.

Laurentius Valla, 3.

Lavisse, 36 .

Lavoisier, 149.

Lazarus, 250.

Leclere, I97.

Legere, Vorlesungen, 24.

l.corancl, Prof.. 313.

1. eibnitz, $149,160,166,172,104$, $233,239,242,252,315$.

Leipzig, 206.

l.eo Xili., I66, 261, 263, 264, $267,273,296,316$.

lesson Drawn from Decay of Scholasticism, 153.

Le'x Naturalis, I 39 .

Liberty, 136, 195, 232.

Lille, 204.

Lindsay, on Scholasticism, is.

Iiterary Excellence in Philosophical Treatises, 180.

littré, 2 I 9.

Locke, 220.

locus Naturalis, 120 . I.t9.

logic, $84,140,142,256$ seq. : applied, $258 ; 298$.

Lonvain Philosophical [nstitute, $166,179,204,210,203$ se4.": $267,275,284,288$ seq.

Litcretius, 40.

I.ntoslawski, I84.

M

Magic, 123, 200.

Malebranche, $74, \quad 134, \quad 1.77,194$, 233.

Mandonnet, $6,66,186,279,302$, $3 \mathrm{I} 4$.

Manichtans, т8S.

Mansel, 220.

Mansion, Prof., 227.

Nlariétan, 79,80 .

Marriage, Monogamons, I.39.

Marsilius Ficinns, +1 .

Materia Signata, IOS.

Materialism, 286.

Nathematics, 83 .

Natter and Form Theory, 72, 102, 213.

Maurenbrecher, Ifo, 164, I9s.

Mechlin, Congress of, 268.

Medieval, confounderl with Scholastic Philosophy, 37, 39; modern idea of, 277.

Medium of Sensation, I 30.
Melanchton, 7 I, I 50.

Mercier, 8I, I66, 199, 209, 210, $220,221,230,234,236,261$, 264,267 seq., 270, 28 I, 299, 3 I 5.

Metaphysics, 83; Medieval, is seq., 205 ; / Possibility of, 213 ; Modern, 217.

Methor, 19, 258 .

Methods, see Constructive, Analytico-Synthetic, Inidactic, Pedagogic.

Meuffels, I 58, I 59, I 66, I 72.

Meunier, 292.

Michaël, 86.

Michotte, Prof., 3 ro.

Microcosm, 123.

Middle Ages, definition of, Is.

Mill, J. S., 210, 238, 25\%, 2009.

Minges, 137.

Nineralogi, 225 .

Mixtum, 122

Modern Siciences, zon seq.

Modern Ianguases in Philosophy, 176.

Molière, $14 \pi$.

Monastic Schools, 22.

Monchamp, 151.

Monism, 1+3, 223, 221.

Monograph, i 7 \%.

Nontpellier, 2.3.3.

Horal, Relation to Piblical Studies, 8.1; ()liject, 13 ; ; Con. temporary Systems, 252-25.t; New Scholastic Moral, 255250 .

Norin, (1).

Motion, four kinds, ifo.

(De) Mumnynck, $25 \mathrm{I}$.

Mysticism, and Siholastic ism, $f$ )

$\mathbf{N}$

"Neo" as Prefis, I 57.

Neo-Kantism, 188, 195, I0,6, 217, 260; anoug (atholics, 10.f-197.

Neologism, 157, 18г.

Noo-Platonism, $78,187,242$.

Neo-Scholasticism, Doubt about Title, 157, 158; is a Borly of Doctrines, 150 ; Olll and New Elements, 163,$167 ;$ Not a Mere Resuscitation of the Past, 163; 'Two V'iews of, 181, 189; Rejects (ertain lirrors, 211, 2I2; Tosts What it Retaims, 204, 2015; Raises New Ouesions, 2 I - 4 -2 7 ; Its Future, 262.

Neo-Scholasticism, Shonla be Based on the Sciences, 202, 205, 206; Objections, 207-210. 
Neo-Scholasticism, Not a Theology, I90; Autonomous, I9I, I92; Respects other Disciplines, 192; Not Inseparable from Catholicism, 193; Distinct from Apologetics, 198.

Neo-Thomism, I 59, 275.

Newman, on Philosophy and Science, 202.

Newton, 1.48, I.49.

Nicholas of Cusa, 74, I GS.

Niphus and Achillinus, 4 I.

Nirvanists, 92.

Noel, Prof., 3 Io.

Nostitz-Rieneck, I 6 I.

Nys, 208, 2I 2, 225, 202, 205, 303, 310.

Obligation, Moral, 138.

Observation, in Viblille Ages, se Occam, see Hillium of (f, 4 um.

Occasionalism, 221.

Olivi, Petrus Joannis, I ?

()llé Laprunce, Igé).

()ntologism, I1 $3,193,232,238$.

()ntology, 301 ; see Metuphrias.

Urigin of Itleas, 133 .

Griginess etc. (Mercier), iI

Orti y Lara, 184.

(), twalel, $200,2,5$

\section{$\mathbf{P}$}

Puleo-Sifulastics, I59, 207, 250 . Palmieri, 230.

Pantheism, Medieval Forms of, 40; $223,238$.

Papacy, 164.

Parallelism, Psycho-physical, 23.

Paris University, $23,24,16,1,1,1$.

l'armeniles, 224.

P'ilscal, los. 236.

Paschasian controverser, 5.8 .

Pasquier, Prof, 293.

Pussive faculty, 129.

Pasteur Institute, 267.

Pathological Psychology, 252.

Patristic Philosophy, if) 7 .

Paulsen, 10, $180,210,224,261$.

Peclagogy, 2f6, 2fr, 2fi).

Pelzer, 11., 314.

Penjon, (), (jo.

Periodicals, 285, 3I I.

Perrier, 1E., 220.

Pessimism, 221, 253.

leter lamian (St.), (I, io).
Peter Lombard, 3I, 66.

Peter of Rheims, 66.

Phenomenism, 2 I 9.

Philology, Scholastic, I74.

Philosophia I'erennis, I6I.

Philo, 7 I.

Philosophy, Notion of, 7, 94;

Relation to Sciences, 85, 200

seq., 263 seq., 273, 295;

System of, 95; Classifications

of Systems, $96,97$.

Asiatic, 43 .

Byzantine, 42.

Catholic, at misnomer, $I t, x$, 199.

- Compareel with Theology : distinct, but intermingled, and often confounded, 7-10, 30, 67, 6.8; Slave or Helpmate, 53-55; Suborelination Material, not Formill, 50, 6i, 72; Insufficient for Definition of Philosophy, $\because 0-55$.

- Medieval anfounded with Sicholastic, 37, 31); sece Sichelasticism.

- Speculative and Practical, 84

Photius, 4 .

Physic and Wetaplysics, $281,282$. Phisic. Medirval, 83, 115 sey., izo; Return to, 2.8: Nolern, $271,393$.

Physiology, 230.

Picavet, $6,10,37,55,68,279$. 291,302 .

Pius X., 207.

Planets, 121 .

Plate, $75,10(), 125,161,260,315$.

Platonism, $77,47,127,165,2.42$.

Phitar(h, If ().

Political kicononny, ios.

l'orphyrs' (x).

l'ortalie, 1)3, (4, 60.

l'ortugal, Scholatstic Rovival in, $1+4,171$.

lositivism, 185, I88, 213, 215, $232,244,247,257,260$.

lotentia and Actus, 99, 100 .

Practical Philosophy, 84 .

l'reclestination, 58.

l'rejudice against Scholasticism, 177 .

l'rogramme of Louvain Institute, 202 ; of Meclieval Schools, 23, 24.

Propagandism, I67, 177.

l'roperty, Private, I34. 
Protestant, 198 199.

Providence, 115.

Psellus, Michael, 42.

Pseudo-Augustine, I 3.

Pseudo-Denis, 239.

Psycho-Physiology, I70, I81, 245, 304, 305.

Psychology, Medieval Scholastic, I23 seq., 144, 214; Modern Scholastic, 230 seq., 295, 306 ; Animal or Comparative, Criminal and Sexual, 25 I ; Collective or Folk, 250 ; Individual, $25 \mathrm{I}$; Sociological, $25 \mathrm{I}$.

Ptolemy, I2I, I48.

Pythagoras, I6I.

Pythagorism, 77, II4.

\section{$\mathbf{Q}$}

Qualities, 227, 228, 229.

Quintilian, 13.

Ouodlibeta, 25, ifus.

\section{$\mathbf{R}$}

Rambaw1, 36 .

Rationes seminales, $72,118$.

Rationalism, 286.

Raymond Lully, 50, 17 I.

Realism, Exaggerated, fot.

Realism, Moderate, IO5.

Referendum, Swiss, $3(x)$.

Rehmke, 42.

Reid, I34.

Relativism, 220.

Religion and Philosophy, I00.

Renaissance, $3,6,38,41,125,126$, I 46, $171,193,224$.

Renouvier, 96, 97, 181, 220.

Restoration of Scholasticisn, 2 I 3 .

Reuchlin, 41, 71 .

Revelation, 62, 192, 198, 279.

Revival of Scholasticism, Two Conceptions of, 108,181 .

Revue néo-scolastique, 312.

Rhaban Maur, 52, 87 .

Richet, $23 \mathrm{I}$.

Riehl, 207.

Rintelen, I6I.

Ritter, 54, 76.

Romance, 195 .

Roman Church, and Philosoply, I 58.

Rome and Louvain, 275.

Rosmini, 193, 194, 198.

Rubczinsky, 302 .

Rubino, 23.

\section{$\mathbf{S}$}

Sacrilege, Scholastic, 158.

Sanscrit, 174.

Sapientia, 80, 82.

Schiller, 241 .

Schneid, I66.

Scholasticism, and Aristotle, 77 ;

Decline of, 145, 153; and

DS Sciences, 20I ; Revival of, 259.

¿277; New Scholasticisn, 28t seq.

Scholastic Manuals, I 45 ; of Lonvain Institute, $298 \mathrm{seq}$.

Scholastic and Modern Philosophy, Sources on Relations, 161 .

Scholastic Philosophy, Vagueness of Term, 3; Confusion with Medieval Philosophy, 37, 39; and Printing, I5; and the Schools, I3; Meaning adopted, 45, 46, 51; Growth in Middle. Ages, 47: Unity and Originality, $4^{8}$; Deviations from, 50 ; Dominant in Middle Ages, 50 ; Relation to Theology, 53 I04, 67,73 .

Scholastic Theology, 6.3.

Scholasticus, 13.

Scholasticity, 50, 57, 70.

sichopenhaner, $13,213,210,238$, 253.

Schiitz, 23.

Scientia Subalternans, Subalternata, 62.

Science, Scholastic Concept of, 94, I 40,209 ; Catholics in, 26); Deductive and Inductive, $1+1$, $1+2$; Object, Material and Formal, 9; Unity and Solidarity of, $(x)$; Merlieval Classification of, 79; Multiplication of Modern, 200; Relation 10 Philosophy, 20I.

Scotism, on Distinction, 101, 107, 113 ; on Principle of Individua. tion, IO8; Voluntarism of, I I3 ; on Knowledge, 132; on IVill, 136; on Immortality, 126.

scotus, $v$. Duns Srotus and Eviugena.

Secretan, I64.

Serninar, I70, 3 I I.

Sensation, Senses, 128, 1 29.

Sensibile, Proprium, Commun" a $2 S$.

Sex-Psychology, 25 I.

Sibenaler, 292.

Sidgwick, 254. 
Siger of Brabant, 30, 4I, I88, 314 . Simplicius, 77.

Sociology, 180, $250,256$.

Sorbonne, 205.

Soul, Spirituality and Immortality of, $125,126,234$.

- Origin of, 127; Silnstintial Form of Bolly, 124, 125.

Spain, Scholastic Revival in, 146, I 71 .

Species Intentionales, 73, 130; misinterpreted, 131, 134, 147, 212.

Spencer, of , 181, 18s, 220, 222, $24 \mathrm{I}, 253,2(x)$

Sphynxes, 15s.

Spinoza, 20.

Spiritus Plusicus, 125.

Spirituality of Soml, 126, 23.1.

Stars, IIC.

Stein(lual, 2̌ol.

Stein, 157 .

Stepleer I. "Slie, 253.

Stephe'n of lomrs, $(x)$.

Stereochenistry, $2(x)$.

Strickl, 6.

stoicism, language of $32 ; 75$. 165.

Suarez, 47, I 43, 1.4\%.

Subjectivism, 215, 216, 215, 2(x).

sublunary Elenents, 121.

Subordination of Philosophy to Theology, 53 sey, Iyz.

Substance (u. Accielent), Iex).

Substantial (hange, 116).

Syllogism, 27, 28, 1 f 1, $1(x), 239$, 257.

synderesis, I.3\%.

\section{$\mathbf{T}$}

Taillandier, St. René, 42 .

Tatint, 5, $84,48,185,219,232$, $235,243,294$.

Talano, 77, 165.

Tetesints, 125.

Terminism, $106,134$.

Terminology, sifulastic and Modern, 3.

Themistius, 77.

Theology (Theolicy), $8,5 s, 50,70$, 1 I I seq. : 22I-225, 300.

Theoplurastus, 13.

Thierry of Chartres, 25.

Thiéry, Prot, 202, 3615, 310.

Thing-in-itselt, 210, 222, 237 .

Thomas Aquinas, 9,20 ; and the Older Scholastics, 49; and Mysticism, 09; and Authority,
$78 ; 102,108$; on Substantial Forms, II 7 ; on Origin of Icleas, 134, I 35,138 ; on Astronomy, I 50 ; on Existence of Ciod, $187 ;$; $198,224,238,255$, 260.

Thomism, $78,47,187,277$, t pussim.

Thurot, 50.

Timans, 118.

Tongiorgi, 236.

Torreille's, th.

Torricelli, 1 fo.

Praclition, in Philosoplyy, Ifo.

Tratelitionalism, 103, 21,0).

Transcendence, 223.

Tionscendental Esthetic, 23 ().

Tranulations of lonvitin Mammals, $3 \mathrm{I}+\mathrm{t}$

Transulatantiation, 5.2 .

Trialic: Sicheme, 2(), if (x).

Irinity, 5 s.

Trivium and Onadrivinu, se .1rt

Tulumen, $2(1) ;$

'ivrrell, $4,-$,

Ithaghs, I94.

1 therweg-Heinze, $3,13,37,53$.

Iniversal ldeas, so sey., $105-$ $107,132,237,23 \%$.

lpanishats, 71, 14, 162, 174.

Itilitartanisnt, $213,2.42,252$.

Vacant, 64, 302.

Vaihinger, 34.

Valentiner, 16.

Valla, 3.

Valmy, 51.

Ván Wedllingan, itos.

Vasquez, f7, 1f().

Vedelic llymos, ifiz.

Vernacular, first l's of in Philosophy, I $7 \mathrm{I}$.

Vicetio, Antonius of, 2.3.

Victor, school of St., 63. 6.4.

Vincent of Beaurais, 87 .

lirtutes octulter, 228.

lives, Indovicus, 4. 75.

livisection, and simplicits of Forms, 21 2 .

Voluntarism, Medieval, 137, I3. ; Kiantian, 10()$.

Von Hartling, 161.

Vorländer, $8,3+$.

rulgarls Cognitio, 200, 207. 
$\mathbf{W}$

Walter of St. Victor, $O 6$.

Weber, 245 .

Weissmann, 233.

Werner, I 29.

William of Auvergne, I3 I, 134, I $35,188$.

William of Occam, 46, I 26,132 , I $35,136,147,222$.

Willmann, 6, 35, 55, 76, 78, 79, $85,80,90,97,167,186,247,250$.

Windelband, on Scholastic and Medieval Philosophy, 39; on
Theology, 54; on Voluntarism, 137.

Wissenschaftslchve, 186.

IVolff, 35.

(De) Wulf, 68, I62, 243, 279, 292, $302,310,315$.

Wundt, I6, 181, 189, 206, 219 . $245,246,250,278,295,305,315$.

\section{$\mathbf{z}$}

Zeller, 7 I, ro8.

Zurich, 267. 


Wulf, Maurice de.

. $\$ 86$ 
II)

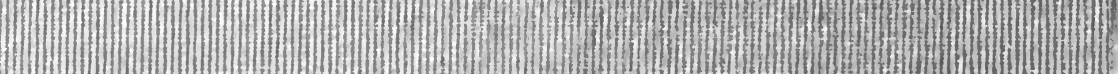

